UNIVERSIDADE DE SÃO PAULO

INSTITUTO DE GEOCIÊNCIAS

\title{
QUIMIOESTRATIGRAFIA ISOTÓPICA (C, O, S e Sr), GEOCRONOLOGIA (Pb-Pb e K-Ar) E PROVENIÊNCIA (Sm-Nd) DAS ROCHAS DA FAIXA PARAGUAI NORTE, MATO GROSSO
}

\author{
Milene Freitas Figueiredo \\ Orientadora: Profa ${ }^{a}$ Dra. Marly Babinski
}

TESE DE DOUTORAMENTO

Programa de Pós-Graduação em Geoquímica e Geotectônica

SÃO PAULO 

"O erro não se torna verdade por se difundir e multiplicar facilmente. Do mesmo modo que a verdade não se torna erro pelo fato de ninguém a ver." (Mahatma Gandhi) 



\section{AGRADECIMENTOS}

Um agradecimento redigido na madrugada do prazo final merece clemência se de alguém se esqueceu. Às vezes as adversidades nos alcançam, mas sempre há quem do nosso lado esteja pra ajudar, ou simplesmente apoiar. Meu desejo é o de me lembrar de todos os que, de alguma forma, participaram desta conquista.

Como o primeiro da lista, não poderia deixar de colocar aquele que foi em todos os momentos meu grande amigo e mestre, a quem muitos chamam Deus. Em seguida aos que foram sempre meu motivo para avançar e superar meus próprios limites, Roberto e Elizena (meus pais), meus modelos de bravura e coragem. Junto deles, agradeço ao grupo que me ensinou a trabalhar em equipe e a dividir tudo o que se tem, Rafael, Gabriel e Daniela (meus irmãos). Agradeço também as pequenas/grandes alegrias que esta equipe me deu, Matheus, João Vitor e Davi (meus sobrinhos). Ao meu namorado, Luiz, que tanto se dedicou nestas últimas semanas, me ajudando com os afazeres da casa e no último dia em tudo o que foi necessário.

Acredito que os quatro anos e meio de pesquisa resultaram em grande amadurecimento pessoal e profissional, acompanhado de conhecimentos novos e interessantes descobertas, 0 que certamente é devido a uma brilhante orientação. $E$ isso eu devo primeiro a minha orientadora Marly Babinski, sempre competente, dinâmica e bastante crítica. Também fui lisonjeada com a extraordinária convivência com meu orientador de estágio de doutorado sanduíche nos Estados Unidos, o Professor Alan Jay Kaufman, sempre atualizado e aberto a novas idéias e possibilidades. Muito do avanço e amadurecimento em meus conhecimentos geológicos, expressados nesta tese, devo a inúmeras batidas nas portas dos professores Thomas Fairchild, Rocha Campos, Paulo Boggiani, Ginaldo Campanha e Setembrino Petri, bem como importantes discussões com os professores Carlos Alvarenga, Roberto V. Santos e Elton Dantas. À professora Ana Goes, meus agradecimentos pela correção do uso correto dos termos sedimentológicos. Muitos destes (Thomas, Rocha, Boggiani, Alvarenga e Roberto), de presença imprescindível no campo, muitas vezes regando-o a muito bom humor. De maneira especial, agradeço o professor Francisco Pinho pelas discussões e por todo suporte na preparação da infraestrutura de campo. Junto dele, agradeço à Geomin e o apoio na infraestrutura de campo, nas pessoas de Álvaro P. Quadros, Carlos J. Fernandes e Elzio S. Barbosa. Agradeço também à UFMT pelos carros. Aproveitando o ensejo "campestre", recordo os membros das equipes de campo, ainda não citados aqui, que auxiliaram na aquisição dos 400 pontos de GPS. Aos alunos de graduação (a maioria já geólogos) Cyntia, Victor, Pedro, Tiago, Douglas e Leandro, obrigada pela ajuda na amostragem e perfis geológicos. Aos motoristas sempre empenhados, incansáveis e pacientes com tanto pára e segue, especialmente Vilson e Dito. Agradeço também a confiança e permissão de trabalho dos proprietários e responsáveis de cada área: João Borba (Propriedade Meu reino encantado); Zé Luiz (Fazenda Bauxi); Sr. Valete e família (Faz. Sete estrelas); Beto, Ademar e Vera (Faz. Sta Terezinha); Geraldo; Laurindo e Evandro (Faz. Estivado); Sr. Luiz e o capataz Valdinei, por todo auxílio e acolhida (Fazenda Serra Azul), à equipe COPACEL, sempre acolhedora, disponível e prestativa, nas pessoas de Cássia, Cassiano, Pedro e Oscar; à Fábrica de Cimento Itaú e ao geólogo Fanio, principalmente pelas discussões e troca de informações sobre a região; Sinvaldo (Carmelo); e Edson Otomura (Minas Cal).

Para desenvolver esta pesquisa, incomodei o pessoal de 8 laboratórios do IGc/USP e de mais 5 laboratórios na University of Mayland. Em todos eles fui muito bem recebida. A começarpelo Laboratório de Laminação, que tão rapidamente prepararam as muitas lâminas 
que solicitei. O pessoal do Laboratório de Química foi formidável na acolhida e em tudo solícitos, Ricardo, Maria Inês, Margareth e Sandra, muito obrigada. A estes se soma Paulo Mori, do Laboratório de Fluorescência de raio-x, sempre bem humorado e admirador de minhas longas madeixas. Igualmente a estes, estão Luis, Edson e Aline, do Laboratório de Isótopos Estáveis, que literalmente me abriram as portas e foram sempre rápidos na entrega das análises. O super Vasco, do laboratório de preparação e separação, foi sempre competente, disposto e criativo, bem como rigoroso. Obrigada por toda ajuda. Não poderia deixar de fora o Samuca, que me ajudou no corte das amostras. O pessoal dos laboratórios de $\mathrm{Rb}-\mathrm{Sr}$ (Solange), $\mathrm{Pb}-\mathrm{Pb}$ (Isabel), Sm-Nd (Liliane) e K-Ar (Arthur), mais as irmãs Sonoki (Helen e Ivone) foram sempre muito competentes e disponíveis em tudo o que se referia à análise de minhas amostras. I thank also the colleagues from UMD labs Craig, Natalie and Eugenia, very kind and friendly people from Jay's group. From Farquar's group I cannot forget Sang Tae, Nanping and Harry, by discussions and ideas about procedure and by providing good humor in my lab days. Talking in good humor, thanks Bill for your smiling in chem. store and for the mug. I thank the grad colleagues Barry, Kristen, Rick and another for companionship. Special thanks to Sandy, the loveliest secretary ever seen. Thanks people from CSC that guaranteed my faith living, some delicious dinners and good company, in special Raul, Kevin and Marc. Also, my gratitude to John and Paul because the happy moments. Obrigada Gustavo, Priscila e Aline pela dedicação no laboratório durante a bolsa pibic. Se não fossem vocês, algumas coisas não estariam prontas. Chico Bill e Pânico, obrigada pela ajuda e disponibilidade dos equipamentos do laboratório de estudos de terrenos cársticos. Angélica, obrigada pela ajuda com as microfotografias. Não poderia deixar de lembrar todos os amigos que tornaram este período longe da família mais agradável. Ao pessoal do GPP (Grupo de Partilha de Profissionais), muito obrigada pelo enriquecimento espiritual, companhia e baladas. Maria e Marcelo, amigos trêslagoenses que seguram a barra da amiga aqui. Veridiana, obrigada pelas tabelas, impressão e pipocas. João Paulo, Fátima e Aníbal, pela boa e divertida convivência em casa. Ramiro, pelas boas conversas e pelas pipocas doces gigantes da Bolívia. Alejandro, Marta e Ariana (a geofamília), especialmente Marta pela ajuda na impressão. Aline, a última companheira (mais velha comigo) de pós-graduação. Geane Carolina, recém chegada no instituto, obrigada pela ajuda com as planilhas. Evelyn, Felipe, Guilherme, Liza, Bernardo e Ricardo, as discussões no nosso Grupo de Estudos do Neoproterozoico foram enriquecedoras e me deram muitas idéias. A todos os funcionários que me toleraram nesses anos, apoiaram, ajudaram e me fizeram rir muito: Tadeu, do Apoio Acadêmico, pela versatilidade em cuidar de tantas coisas sem deixar de estar disponível aos alunos; Ana Paula, competente e sempre tirando nossas dúvidas, e Magali, um poço de bom humor, ambas da secretaria de pós-graduação; Erickson, da Informática, por tantos pôsteres impressos e probleminhas de internet resolvidos; Sr. Everaldo e todo o pessoal da Segurança, pela gentileza e prontidão; à Ivone, Maria Celeste e Sônia, do financeiro, por cuidarem da parte mais chata sem perderem o sorriso, a prestações de contas; Soninha e Valéria da secretaria do GMG, por resolverem todas as questões de infra-estrutura; Érika e todo o pessoal da Biblioteca, pela simpatia e compreensão; Zeca e Wagner do áudio visual, pela alegria e dinamicidade; ao pessoal da gráfica, Claudionor, Sr. José, Henrique, pela alegria e disposição. 


\section{ÍNDICE}

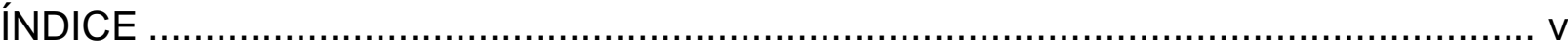

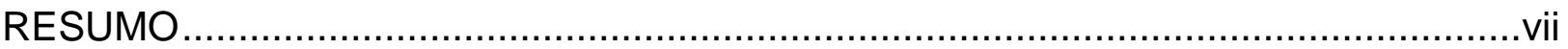

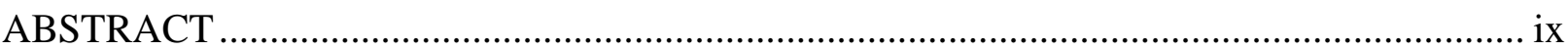

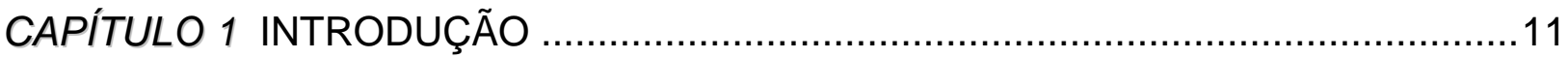

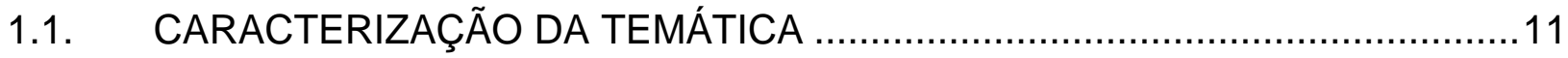

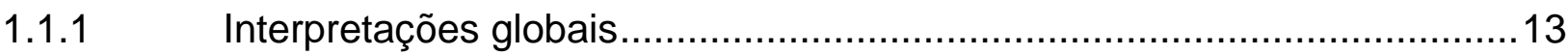

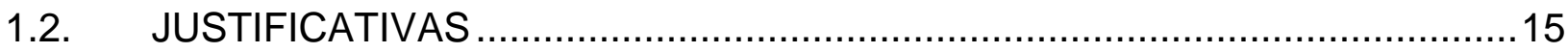

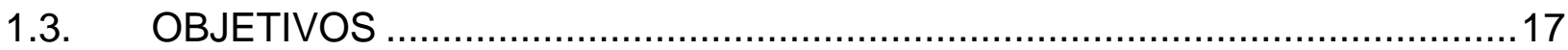

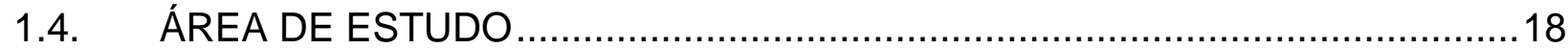

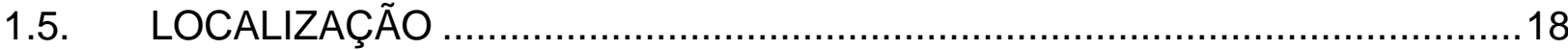

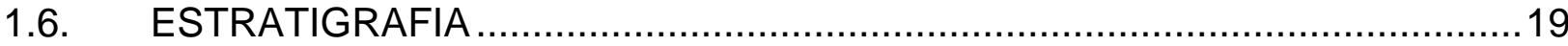

1.6.1 Formações Puga, Bauxi e Grupo Cuiabá ..........................................19

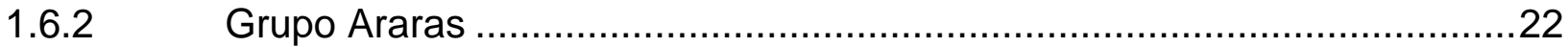

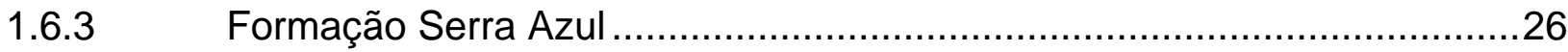

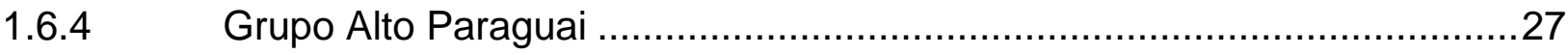

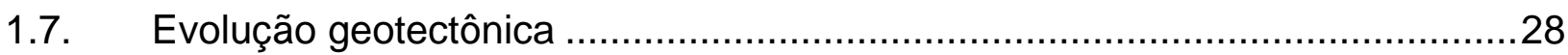

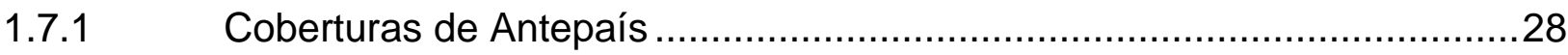

1.7.2 Domínio Tectônico Externo $\quad$................................................................. 28

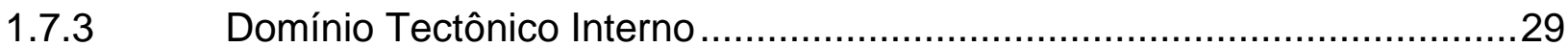

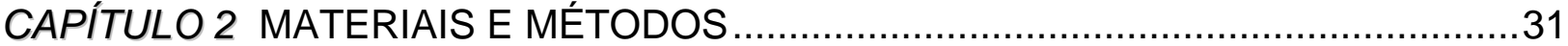

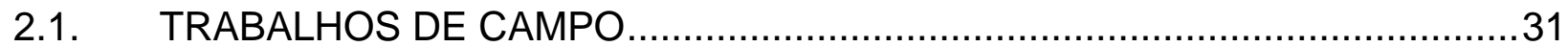

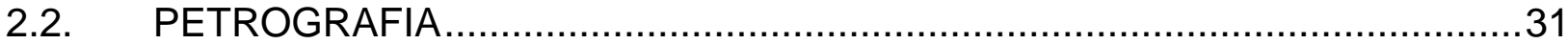

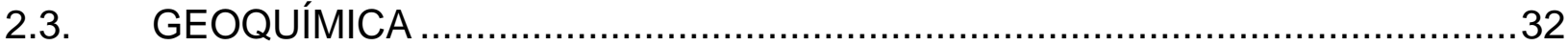

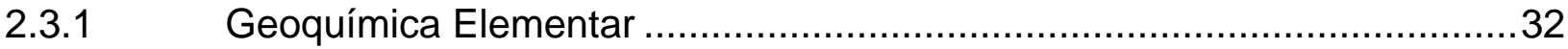

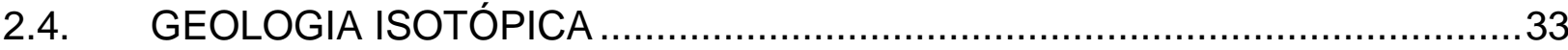

2.4.1 Análise de isótopos estáveis .....................................................33 


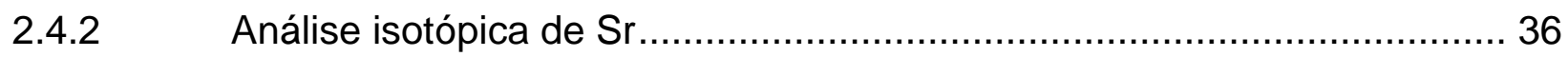

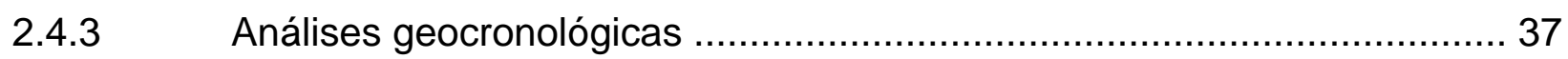

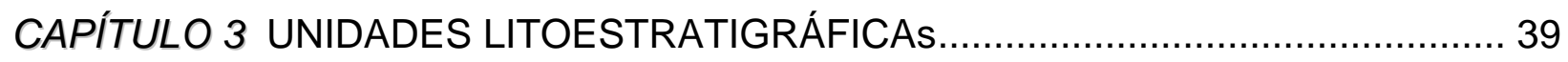

3.1. A FORMAÇÃO pUGA NO EXTREMO NORTE DA FAIXA PARAGUAI........... 39

3.1.1 Descrição das seções ....................................................................... 40

3.1.2 Ambiente Deposicional da Formação Puga ............................................ 49

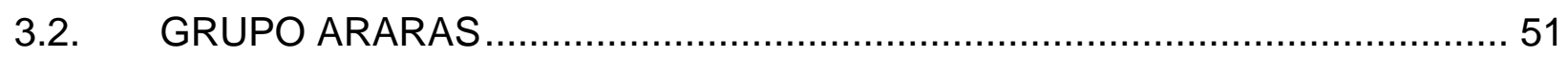

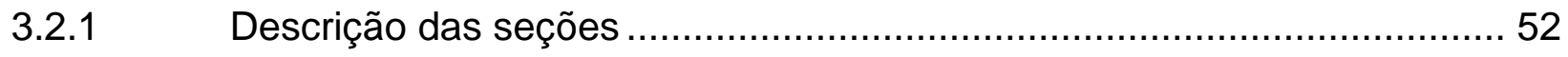

3.2.2 Ambiente Deposicional do Grupo Araras ............................................ 79

3.3. ARTIGO 1: NOVA UNIDADE LITOESTRATIGRÁFICA REGISTRA GLACIAÇÃO EDIACARANA EM MATO GROSSO: FORMAÇÃO SERRA AZUL ........ 82

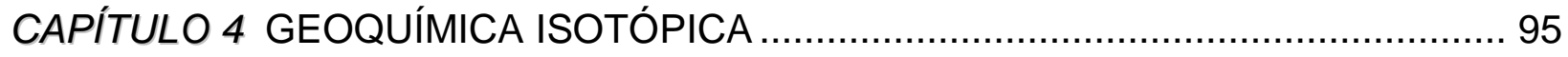

4.1. ARTIGO 2: QUIMIOESTRATIGRAFIA ISOTÓPICA (C, O e Sr) de carbonatos

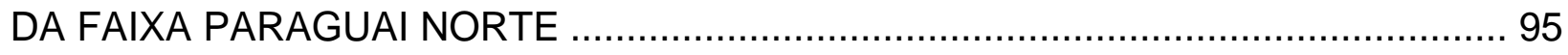

4.2. ARTIGO 3: ABUNDÂNCIA ISOTÓPICA ANÔMALA DE ENXOFRE PESADO NOS CARBONATOS EDIACARANOS DA FAIXA PARAGUAI NORTE................... 134

CAPÍTULO 5 GEOCRONOLOGIA, PROVENIÊNCIA E TECTÔNICA....................... 153

5.1. ARTIGO 4: IDADES Pb-Pb DE CARBONATOS DA FAIXA PARAGUAI NORTE

5.2. ARTIGO 5: PROVENIÊNCIA DAS ROCHAS SEDIMENTARES

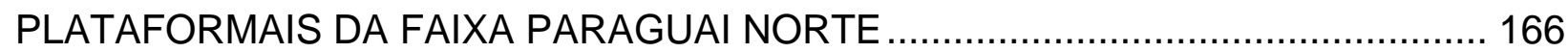

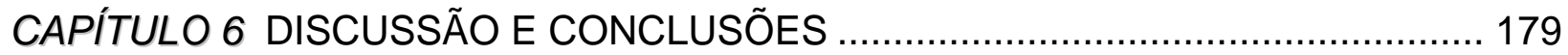

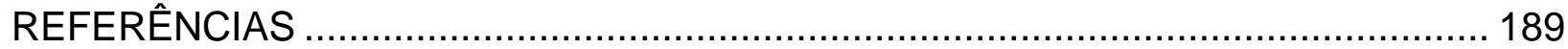




\section{RESUMO}

Anomalias biogeoquímicas expressivas têm sido reconhecidas em rochas marinhas neoproterozoicas depositadas em todos os continentes, não havendo similares ao longo do Fanerozoico. O interesse nesta Era aumentou nos últimos anos, especialmente em relação ao Ediacarano, período que precede a grande Explosão de Vida Cambriana e que abriga os primeiros organismos macroscópicos, conhecidos como Fauna de Ediacara. Assim, o entendimento das condições paleoambientais e paleoclimáticas, bem como o estabelecimento da cronologia dos eventos, é fundamental no entendimento da evolução da biota no planeta durante este período.

As rochas da Faixa Paraguai Norte, na região de estudo, registram a ocorrência de duas glaciações, uma criogeniana e outra ediacarana (formações Puga e Serra Azul), separadas por uma espessa plataforma carbonática (Grupo Araras), que registra anomalias biogeoquímicas na água do mar ediacarano. Estas rochas foram depositadas na margem sudeste do Craton Amazônico, no intervalo de tempo entre a quebra do paleocontinente Rodínia e a colagem do Gondwana.

O presente trabalho é apresentado na forma de artigos e apresenta estudos de: i) quimioestratigrafia isotópica ( $\mathrm{C}, \mathrm{O}, \mathrm{S}$ e $\mathrm{Sr}$ ) de detalhe nos carbonatos do Grupo Araras e da Formação Serra Azul; ii) proveniência (Sm-Nd) das rochas terrígenas das formações Puga e Serra Azul, bem como da base da Formação Raizama; e iii) geocronologia (Pb-Pb em carbonatos e K-Ar em clastos vulcânicos) da Formação Serra Azul.

Os valores de $\delta^{13} \mathrm{C}$ evidenciaram duas anomalias negativas (ca. - 6\%) pósglaciais e um gradiente de até $2,5 \%$ ao longo da bacia, no período interglacial. As razões ${ }^{87} \mathrm{Sr} /{ }^{86} \mathrm{Sr}$ (entre 0.7074 e 0.7087 ) mostraram uma evolução coerente com a esperada para o oceano ediacarano. Os valores de $\delta^{34} \mathrm{~S}$ obtidos nos sulfatos-traços dos carbonatos variaram de 22 a 61\%, enquanto que nas piritas variaram de 11 a 43\%o, sendo os mais pesados já registrados no tempo geológico (acima de 48\% e 30\%, respectivamente). As idades modelo $\left(\mathrm{T}_{\mathrm{DM}}\right) \mathrm{Sm}-\mathrm{Nd}$ obtidas em rochas terrígenas das formações Puga, Serra Azul e Raizama encontram-se entre 1,6 e 2,2 Ga, mostrando contribuição variável, ao longo da seção, com predomínio de fontes localizadas a norte e a leste da bacia precursora da Faixa Paraguai. As idades K-Ar obtidas em clastos vulcânicos recuperados da Formação Serra Azul variaram de 730 a 1167 Ma, 
evidenciando uma fonte jovem, distinta do esperado para o Cráton Amazônico. A idade isocrônica $\mathrm{Pb}-\mathrm{Pb}$ de $596 \pm 26 \mathrm{Ma}$ determinada em carbonatos da Formação Serra Azul corrobora sua correlação com a Glaciação Gaskiers, datada em 580 Ma. 


\section{ABSTRACT}

Expressive biogeochemical anomalies have been recognized in Neoproterozoic marine rocks deposited worldwide, with no similar record throughout the Phanerozoic. The interest in this Era have been increased, especially on the Ediacaran time, the period that precedes the great CambrianLife Explosion, and houses the first macroscopic organisms, which are known as the Ediacaran Fauna. Thus, the understanding of paleoclimatic and paleoenvironmental conditions, associated with the establishment of the chronology of the events is crucial in the understanding the evolution of biota on the planet during this period.

The rocks of northern Paraguay Belt in the study area record the occurrence of two glaciations, where one is Cryogenian and another is Ediacaran (Puga and Serra Azul formations). These glacial deposits are separated by a thick carbonate platform (Araras Group), which records biogeochemical anomalies in the Ediacaran seawater. These rocks were deposited in the southeastern margin of the Amazonian Craton, in the time interval between the breakup of the Rodinia Paleocontinent and the assemblage of the Gondwana.

This work is composed by five articles, whose study scopes are: i) detailed isotope chemostratigraphy ( $\mathrm{C}, \mathrm{O}, \mathrm{S}$ and $\mathrm{Sr}$ ) in carbonates from the Araras Group and the Serra Azul Formation; ii) provenance (Sm-Nd) of the siliclastic rocks from the Puga and the Serra Azul Formations and the base of the Raizama Formation; and iii) geochronology ( $\mathrm{Pb}-\mathrm{Pb}$ in carbonate and $\mathrm{K}-\mathrm{Ar}$ in volcanic clasts) from the Serra Azul Formation.

The $\delta^{13} \mathrm{C}$ values showed two post-glacial negative anomalies (ca. - 6\%) and a gradient of up to $2.5 \%$ along the basin, during interglacial period. The obtained ${ }^{87} \mathrm{Sr} /{ }^{86} \mathrm{Sr}$ ratios (between 0.7074 and 0.7087 ) showed a consistent trend with that expected for the Ediacaran sea water. The trace sulfate extracted from obtained carbonates yielded $\delta^{34} \mathrm{~S}$ values from 22 to $61 \%$, whereas the pyrites ranged between 11 and $43 \%$. These $\delta^{34} \mathrm{~S}$ values are the heaviest ever recorded in geologic time (above 48\% and 30\%, respectively). The Sm-Nd model ages $\left(T_{D M}\right)$ obtained from siliciclastic rocks from Puga, Serra Azul and Raizama formations range from 1.6 to $2.2 \mathrm{Ga}$, and indicate a variable contribution along the section, with predominant sources coming from areas at north and east of the precursor basin. Recovered volcanic clasts from the Serra Azul Formation yielded $\mathrm{K}-\mathrm{Ar}$ ages between 730 and $1167 \mathrm{Ma}$, revealing a non expected 
young source for areas on the Amazon Craton. The $\mathrm{Pb}-\mathrm{Pb}$ isochron age of $596 \pm 26 \mathrm{Ma}$ was determined in carbonates from the Serra Azul Formation and corroborates its correlation with Gaskiers Glaciation which was dated at $580 \mathrm{Ma}$. 


\section{CAPÍTULO 1 INTRODUÇÃO}

O Neoproterozoico vem ganhando cada vez mais importância na compreensão da evolução da superfície terrestre, especialmente com as descobertas realizadas nas últimas duas décadas, que acusam mudanças de grande amplitude na química dos oceanos, da atmosfera e da biosfera, especialmente durante o Ediacarano. Muitos dados sedimentológicos, estratigráficos, geoquímicos e paleobiológicos têm demonstrado uma complexidade dos processos que ocorrera neste período, gerando uma ampla diversidade de interpretações acerca dos resultados anômalos. Neste capítulo, será apresentado um panorama das discussões latentes para a evolução durante o Ediacarano, bem como a contextualização desta pesquisa e da geologia da área de estudo.

\subsection{CARACTERIZAÇÃO DA TEMÁTICA}

Durante os primeiros quatro bilhões de anos do Planeta Terra, período conhecido como Pré-Cambriano, ocorreram grandes transformações em sua superfície, como o surgimento dos primeiros continentes e oceanos, a instalação de uma atmosfera e sua oxigenação e o início da vida. Este longo período termina com a grande Explosão de Vida Cambriana (Valentine et al., 1991), marcada por uma intensa diversificação e radiação de organismos complexos nos oceanos há $542 \mathrm{Ma}$. Este salto evolutivo despertou o interesse de diversos pesquisadores para o período que 0 antecede, a Era Neoproterozoica, na procura do entendimento dos mecanismos responsáveis.

As rochas sedimentares do Neoproterozoico (1 $\mathrm{Ga}$ a $542 \mathrm{Ma}$ ) abarcam um conjunto de feições geológicas de difícil explicação quando utilizado o uniformitarismo, ou modelos atuais, o que permite a proposição das mais variadas interpretações. A primeira das características marcantes é o reaparecimento de formações ferríferas, após cerca de $1 \mathrm{Ga}$ de intervalo estratigráfico sem essa ocorrência (Martin, 1965), o que exigiria uma nova oxigenação da atmosfera e dos oceanos. Em seguida, o 
empilhamento contínuo de diamictitos glaciais e carbonatos (Roberts, 1974; Fairchild, 1993) apontaram mudanças climáticas bruscas. Dados paleomagnéticos posicionaram estas glaciações próximas ao equador (Williams, 1975; Schmidt \& Williams, 1995), evidenciando climas extremos. As assinaturas biogeoquímicas e isotópicas preservadas nas rochas são anômalas em relação ao restante do registro geológico, especialmente durante o Ediacarano (Neoproterozoico superior), revelando profundas mudanças na composição química dos oceanos e da biota existente (Knoll et al., 1986; Knoll, 1991; Kaufman et al., 1991; Kaufman et al., 1997).

Considerando todo o registro geológico, é no Ediacarano que se observam variações de grande amplitude nas composições isotópicas de carbono e de enxofre, cuja observação é facilitada pelo grande volume de carbonatos depositados. Ao longo desse período, são observados, ao menos, três eventos de enriquecimento em isótopos leves de carbono $\left({ }^{12} \mathrm{C}\right)$, sendo o primeiro imediatamente após a Glaciação Marinoana (Hoffman et al., 1998), o segundo por volta de $590 \mathrm{Ma}$ (McFadden et al., 2008) e o terceiro, de maior duração e conhecido como Shuram, com término em 551 Ma (Burns \& Matter, 1993; Calver, 2000; Corsetti \& Kaufman, 2003; Le Guerroé et al., 2006; Jiang et al., 2007; Melezhik et al., 2009). Em relação ao enxofre, variações de grande amplitude na sua composição isotópica têm sido registradas principalmente num período que abrange o Ediacarano e o Cambriano inferior (Holser, 1977; Strauss et al., 2001 e Strauss, 2004), sendo as rochas dessa idade (que contêm sulfato) significantemente enriquecidas em isótopos pesados $\left({ }^{34}\right.$ S; Claypool et al., 1980, Strauss, 2004).

O registro sedimentológico mostra a ocorrência de duas glaciações associadas às anomalias negativas de carbono ediacaranas. A primeira, já mencionada acima, é bem documentada em vários continentes (Glaciação Marinoana), tendo ocorrido por volta de $635 \mathrm{Ma}$. A segunda, mais restrita, é conhecida como Glaciação Gaskiers e possui $50 \mathrm{~cm}$ de calcário sobreposto a ela, com anomalia negativa de carbono (aumento de ${ }^{12} \mathrm{C}$ em relação ao ${ }^{13} \mathrm{C}$; Myrow \& Kaufman, 1999), tendo ocorrido há 580 $\mathrm{Ma}$ (Bowring et al., 2003). Esta glaciação ediacarana foi correlacionada com a segunda anomalia negativa encontrada na China (Condon et al., 2005), cuja correlação foi posteriormente contestada por McFadden et al. (2008) com base na idade de $599 \mathrm{Ma}$ obtida em nível estratigráfico acima da segunda anomalia (Barfod et al., 2002). Como também não existe registro glacial associado à terceira anomalia negativa (Calver, 2000; Corsetti \& Kaufman, 2003; Le Guerroué et al., 2006, Jiang et al., 2007; Melezhik et al., 2009), a correlação desta com a Glaciação Gaskiers permanece questionável. 
Diante da escassez dos dados geocronológicos necessários à correlação entre as sucessões carbonáticas e terrígenas, têm se utilizado amplamente a quimioestratigrafia com isótopos de estrôncio associado aos isótopos de carbono em rochas carbonáticas. O estrôncio possui um tempo de residência na água do mar maior que o tempo necessário à sua homogeneização termohalina, fazendo com que sua composição isotópica seja a mesma em carbonatos depositados ao mesmo tempo (Banner, 2004). No Ediacarano as razões isotópicas de estrôncio aumentam gradativamente em direção ao Cambriano, com uma repentina diminuição no limite entre estes dois períodos. Este aumento gradativo está associado às orogêneses responsáveis pela colagem do Supercontinente Gondwana ao longo do Ediacarano, provocando um aumento na entrada de estrôncio radiogênico nos oceanos, proveniente da alteração das rochas mais antigas soerguidas.

Após a última glaciação Ediacarana, em um oceano quimicamente diverso do atual e num contexto de construção do Gondwana, ocorre o aparecimento dos primeiros organismos complexos (macroscópicos), entre 575 e 565 Ma (Narbonne, 2005). A partir de então, foram registradas inovações biológicas como mobilidade (> $555 \mathrm{Ma}$ ), calcificação (550 Ma) e predação (< $549 \mathrm{Ma})$, com a extinção desta Fauna de Ediacara no limite com o Cambriano (Narbonne, 2005).

\subsubsection{Interpretações globais}

Todos estes registros são globalmente observados e vêm sendo amplamente discutidos, gerando inúmeras publicações com diversas interpretações, modelos e hipóteses. No entanto, todas estas possuem lacunas e não abrangem todas as feições geológicas encontradas, fazendo com que grande número de pesquisadores lancem mão das mais diversas ferramentas existentes, aprimorando-as ou desenvolvendo novas técnicas que possam auxiliar na solução dessas incógnitas. Assim, o conhecimento geológico sobre paleoclima e os oceanos ediacaranos tem avançado com a crescente produção de dados.

Uma das hipóteses, com maior visibilidade, proposta para explicar estas ocorrências é a Snowball Earth, proposta por Kirschvink (1992) com base em dados paleomagnéticos e aprimorada por Hoffman et al. (1998) e Hoffman \& Schrag (2002) com base nos isótopos de carbono. Esta hipótese propõe uma glaciação global, com extensas plataformas de gelo isolando os oceanos da atmosfera. Nela, as anomalias 
negativas de $\delta^{13} \mathrm{C}$ são explicadas pela inibição dos organismos fotossintetizantes, principais responsáveis pelo fracionamento dos isótopos de carbono. Os carbonatos depositados imediatamente acima dos diamictitos são interpretados como o resultado do aumento da alcalinidade nos oceanos, provocada pelo intenso intemperismo pósglacial.

Esta hipótese foi duramente contraposta por outra chamada Zipper-Rift (Eyles \& Januszczak, 2004), que assume uma origem sin-rift diacrônica para a maioria dos diamictitos de baixas latitudes e admite uma origem glacial de altitude ou de altas latitudes para os diamictitos que apresentam evidências glaciais seguras. Porém, esta teoria não apresenta mecanismos alternativos para as anomalias negativas de $\delta^{13} \mathrm{C}$, sugerindo brevemente que o aumento da atividade tectônica, durante a quebra do Supercontinente Rodínia, e a rápida subsidência das bacias poderiam explicar algumas variações isotópicas.

Uma hipótese alternativa à Snowball Earth, criada para explicar a manutenção da biota durante o período glacial, é a Slushball Earth (Hyde et al., 2000). Este modelo considera o cenário de uma glaciação global, porém com uma faixa de oceano descoberta ao longo do equador (cerca de 40\%), que serviria de refúgio para os metazoários e organismos fotossintetizantes. As anomalias negativas de $\delta^{13} \mathrm{C}$ são atribuídas à liberação de metano (gas hydrate destabilization) durante a inundação do continente e bacias interiores, causada pelo degelo (Kennedy et al. 2001).

Com o avanço das pesquisas, dados geoquímicos e curvas isotópicas de alta resolução têm sido obtidos nas sucessões carbonáticas ediacaranas de diversas bacias. O detalhamento destas sucessões revelou anomalias não vinculadas aos eventos glaciais e variações espaciais nas curvas isotópicas entre sucessões consideradas de mesma idade. Alguns trabalhos sugerem uma oxigenação dos oceanos ediacaranos em pulsos (Fike et al., 2006; Canfield et al., 2007; McFadden et al., 2008; Scott et al., 2008), com sua completa oxigenação antes do Cambriano, enquanto outros sugerem ambientes de águas profundas anóxicas com duração até o Cambriano (Canfield et al., 2008; Shen et al., 2008). O estudo detalhado da Formação Doushantuo, na China, revelou diferenças expressivas na composição isotópica ao longo da plataforma (Jiang et al., 2007; Zhu et al., 2007; Guo et al., 2007; McFadden et al., 2008; Ader et al., 2009). Baseando-se nestas variações isotópicas de acordo com a profundidade, Ader et al. (2009) propõe um modelo de ambiente estratificado para a 
região, admitindo uma camada basal metanogênica associada a um ambiente restrito da plataforma interna. Adicionalmente, Li et al. (2010) identificaram a coexistência de ambientes oxigenados, anóxicos e euxínicos, com base em dados geoquímicos de ferro e isótopos de enxofre. Para explicar tal comportamento, propuseram um modelo de ambiente estratificado com uma cunha euxínica metaestável sobre a plataforma, que pode ser extrapolado para os oceanos ediacaranos.

\subsection{JUSTIFICATIVAS}

As sucessões sedimentares que registram estas importantes mudanças ambientais, que dominaram o final do Pré-Cambriano, também ocorrem no Brasil. Elas podem ser encontradas sobre os crátons do São Francisco e Amazônico e, principalmente, nas faixas móveis que bordejam estes crátons. Assim, as três glaciações neoproterozóicas principais estão registradas nos diamictitos sotopostos às rochas carbonáticas do Grupo Bambuí (Sturtian), Grupo Araras (Marinoan) e Formação Serra Azul (Gaskiers). Apenas na Faixa Paraguai foram encontrados registros de duas destas glaciações, com seus respectivos carbonatos pós-glaciais numa mesma sucessão de rochas, representadas pela Formação Puga, Grupo Araras e Formação Serra Azul (Figueiredo et al., 2005a e 2005b). Além disso, a Formação Serra Azul, recentemente estabelecida (Alvarenga et al., 2007), é considerada a única correspondente da glaciação Gaskiers na América do Sul (Figueiredo et al., 2005b; Figueiredo, 2006), embora Pazos et al. (2008) sugiram que os diamictitos da Formação Sierra Del Volcán, depositados sobre o embasamento paleo- a mesoproterozoico do Complexo Buenos Aires (Sistema Tandilia; Argentina) também sejam correlatos da glaciação Gaskiers, mas ainda com bastante incerteza, pois esta não é encontrada na mesma sucessão litoestratigráfica que as demais rochas consideradas mais antigas.

A área selecionada para este estudo encontra-se no extremo norte da Faixa Paraguai, região central do Estado de Mato Grosso, e possui poucos estudos estratigráficos de detalhe e isotópicos. Os dados geológicos disponíveis se restringem aos mapeamentos geológicos realizados na escala 1:500.000 pelo Serviço Geológico do Brasil (Ribeiro Filho et al., 1975; Luz et al., 1978), na escala 1:50.000 por graduandos da Universidade Federal de Mato Grosso em pequenas áreas (Ganzer \& 
Figueiredo, 2004; Santos \& Coelho, 2004) e dois trabalhos de pós-graduação (Nogueira, 2003; Figueiredo, 2006).

Como na maioria das sucessões neoproterozoicas, as sucessões estudadas são desprovidas de fósseis que poderiam auxiliar na interpretação ambiental e na correlação entre sucessões. Um estudo microfossilífero foi recentemente realizado por Hidalgo (2007) nos carbonatos do Grupo Araras, mostrando uma microbiota característica do Ediacarano, possuindo um significado cronológico bastante amplo e não diagnóstico de profundidade do paleoambiente. Outro estudo, utilizando biomarcadores, foi realizado em betumes migrados para os carbonatos de capa da Formação Mirassol d' Oeste, revelando fósseis químicos de bactérias redutoras de sulfato, bactérias verdes sulfurosas e algas vermelhas (Elie et al., 2007), indicadores de ambientes anóxicos e fóticos. A ausência fossilífera, a pouca resolução estratigráfica dos microfósseis encontrados e a carência de matéria orgânica in situ ao longo de toda a sucessão, releva a importância de se utilizar ferramentas quimioestratigráficas que possibilitem interpretações ambientais e correlações estratigráficas de maior resolução.

Assim, as técnicas escolhidas para o desenvolvimento deste trabalho são as mesmas que vêm sendo aplicadas conjuntamente em várias rochas carbonáticas neoproterozoicas do mundo como bons parâmetros estratigráficos. Adicionalmente, estas metodologias têm elucidado muito a respeito das condições paleoclimáticas e paleoambientais do passado terrestre, em função de que: (i) os isótopos estáveis de C são bons indicadores de ambiente e atividade biológica (Schidlowski et al., 1976; 1979), os isótopos de O são indicadores de processos pós-deposicionais e apontam para temperatura e salinidade do ambiente deposicional-diagenético (Kah, 2001; Kaufman et al., 1995), enquanto que os isótopos de $S$ indicam atividade de bactérias redutoras de sulfato em ambiente anóxico (Kaplan, 1983; Strauss, 2004); (ii) os isótopos de $\mathrm{Sr}$ registrados nos carbonatos marinhos refletem a composição da água do mar no momento da deposição, podendo ser indicadores das variações nas taxas de intemperismo e atividade tectônica (Banner, 2004); (iii) os isótopos de Pb, na ausência de tufos e derrames vulcânicos intercalados, constituem a única ferramenta conhecida capaz de fornecer idades radiométricas da sedimentação dos carbonatos précambrianos (Babinski et al., 1999); e (iv) os biomarcadores revelam a atividade biológica presente e indicam os possíveis organismos que os produziram (Brocks \& 
Summons, 2003; Strauss et al., 1992), o que permite identificar o tipo de fauna presente.

Algumas das metodologias propostas, como os isótopos de $\mathrm{Sr}, \mathrm{C}$ e O, já foram aplicadas com sucesso nos carbonatos da Faixa Paraguai em Mato Grosso do Sul por Boggiani (1998), Boggiani et al. (2003, 2010) e Simon (2007) e em Mato Grosso por Nogueira et al. (2003), Alvarenga et al. (2003, 2004, 2008), Pinho et al. (2003), Figueiredo et al. (2005b) e Figueiredo (2006). Também a datação de carbonatos, com isótopos de $\mathrm{Pb}$, foi realizada nos carbonatos do $\mathrm{Gr}$. Araras, fornecendo uma idade Marinoana, coerente com a sugerida pelos isótopos estáveis (Babinski et al., 2006). Entretanto, análises de isótopos de $\mathrm{S}$ ainda não foram realizadas na Faixa Paraguai, embora esta metodologia venha sendo utilizada em várias outras sucessões précambrianas.

Os dados isotópicos associados ao levantamento estratigráfico podem trazer novas informações quanto às condições de deposição das sucessões sedimentares durante do Neoproterozóico e verificar a aplicabilidade das várias hipóteses existentes, como a Snowball Earth, Gas hydrate destabilization, Slushball e a Zipper Rift.

Assim, o entendimento das condições ambientais e climáticas extremas que precederam a "Explosão de Vida Cambriana" pode auxiliar na explicação dos mecanismos desencadeadores desta extraordinária diversificação da macrobiota e a compreender como a microbiota se desenvolveu e diversificou sob condições atualmente consideradas inóspitas (Corsetti et al., 2006).

\subsection{OBJETIVOS}

O trabalho ora proposto objetiva pesquisar as condições paleoambientais, paleoclimáticas e tectônicas sob as quais foram depositadas as rochas da Formação Puga, Grupo Araras e da Formação Serra Azul, na região centro-sul do Estado de Mato Grosso, e o seu significado no contexto das glaciações globais neoproterozoicas (Marinoana e Gaskiers) e na colagem do Paleocontinente Gondwana. Isso se pretende através do uso de ferramentas quimioestratigráficas, como isótopos estáveis de $\mathrm{C}, \mathrm{O}$ e $\mathrm{S}$ e isótopos radiogênicos de Sr. Devido à incerteza da idade destas rochas sedimentares, pretende-se datar os carbonatos não metamorfizados pelo método radiométrico $\mathrm{Pb}-\mathrm{Pb}$. 
Esse estudo permitiu: (i) a caracterização da Formação Serra Azul, considerada correlata da terceira glaciação neoproterozoica, que não possui muitos dados, mesmo em outros continentes; (ii) a correlação quimioestratigráfica de toda a sucessão estudada com outras sucessões da mesma bacia e mundiais de mesma idade, identificando um sincronismo global, caso exista, com as demais representantes das glaciações Marinoana e Gaskiers; (iii) o refinamento da idade destas glaciações e dos seus padrões de curvas isotópicas temporais; e (iv) o entendimento paleoambiental, paleoclimático e paleontológico deste importante e misterioso período que precedeu a primeira grande evolução e diversificação da vida na Terra.

\section{4. ÁREA DE ESTUDO}

A Faixa Paraguai está localizada na borda sudeste do Cráton Amazônico, composta de rochas sedimentares depositadas numa margem passiva durante 0 Neoproterozoico, posteriormente dobradas pela Orogênese Brasiliana/Pan-Africana.

\subsection{Localização}

A área de estudo localiza-se na porção centro-sul da meso-região do Estado de Mato Grosso, nos municípios de Nobres, Rosário Oeste e Jangada.

As áreas situadas no município de Nobres distam cerca de $130 \mathrm{~km}$ da Capital Cuiabá, cujo acesso é realizado por via asfaltada pelas BR163 e BR364 (Figura 1) e estradas vicinais de leito natural existentes nos arredores de Nobres.

Para as porções situadas no município de Rosário Oeste se utiliza três vias de acesso. O acesso à cidade de Rosário Oeste é o mesmo que se faz para a cidade de Nobres. Para a região de Marzagão, que dista cerca de $110 \mathrm{~km}$ de Cuiabá, o acesso é feito por via asfaltada através da MT251, tomando-se então pela estrada da Usina Hidrelétrica de Manso (Figura 1). A partir desta usina o acesso se dá pela via de leito natural MT351. A partir de Marzagão, utilizaram-se diversas estradas vicinais, sendo acesso para Planalto da Serra a via de leito natural MT241, pela qual se percorre um trajeto de $30 \mathrm{~km}$.

Para as áreas situadas no Município de Jangada, o acesso se dá pelas vias asfaltadas BR163 a partir de Cuiabá, distando cerca de $70 \mathrm{~km}$, e depois pela MT246 até o distrito de Bauxi. A partir desta localidade toma-se a MT160 de leito natural e respectivas estradas vicinais, por aproximadamente $100 \mathrm{~km}$, até a BR070 asfaltada. 


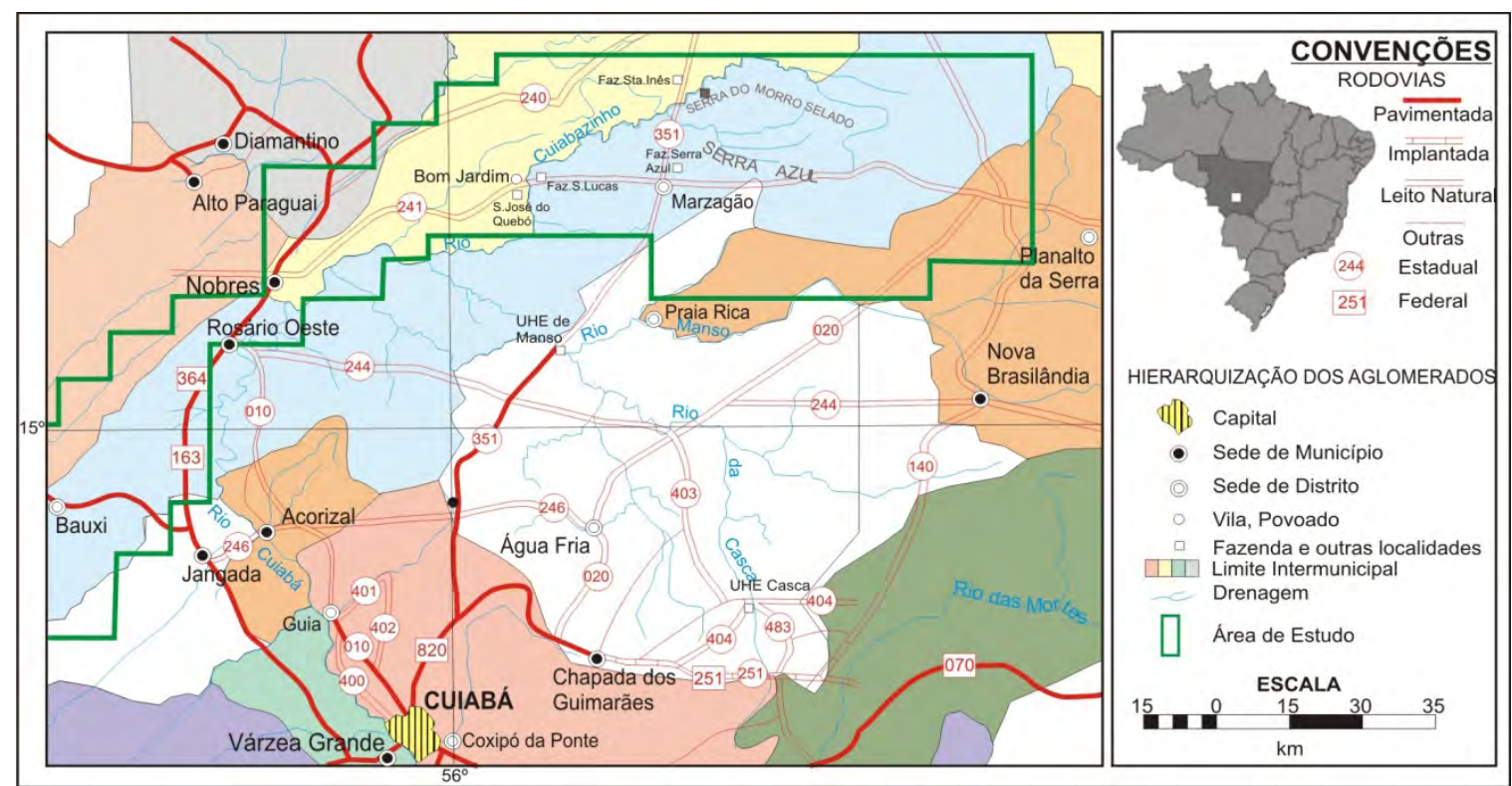

Figura 1. Mapa de localização e vias de acesso à área de estudo (modificado do Mapa Político Rodoviário e Estatístico de Mato Grosso, edição 2000).

\subsection{Estratigrafia}

Neste item será contextualizada a estratigrafia envolvida na geologia regional (Figuras 2 e 3), apresentando os conhecimentos litológicos, geocronológicos e ambientais, disponíveis na literatura, sobre as formações geológicas constituintes da Faixa Paraguai, dando-se maior ênfase ao Grupo Araras e à Formação Serra Azul. Será utilizada a nomenclatura sedimentar na descrição litológica de rochas metamórficas de baixo grau.

\subsubsection{Formações Puga, Bauxi e Grupo Cuiabá}

Estas unidades são consideradas penecontemporâneas por Alvarenga (1988), possuindo uma transição lateral entre elas. Assim, as formações Puga e Bauxi seriam depósitos mais rasos transicionando para os depósitos mais profundos do Grupo Cuiabá, todos depositados sob influência glacial. 


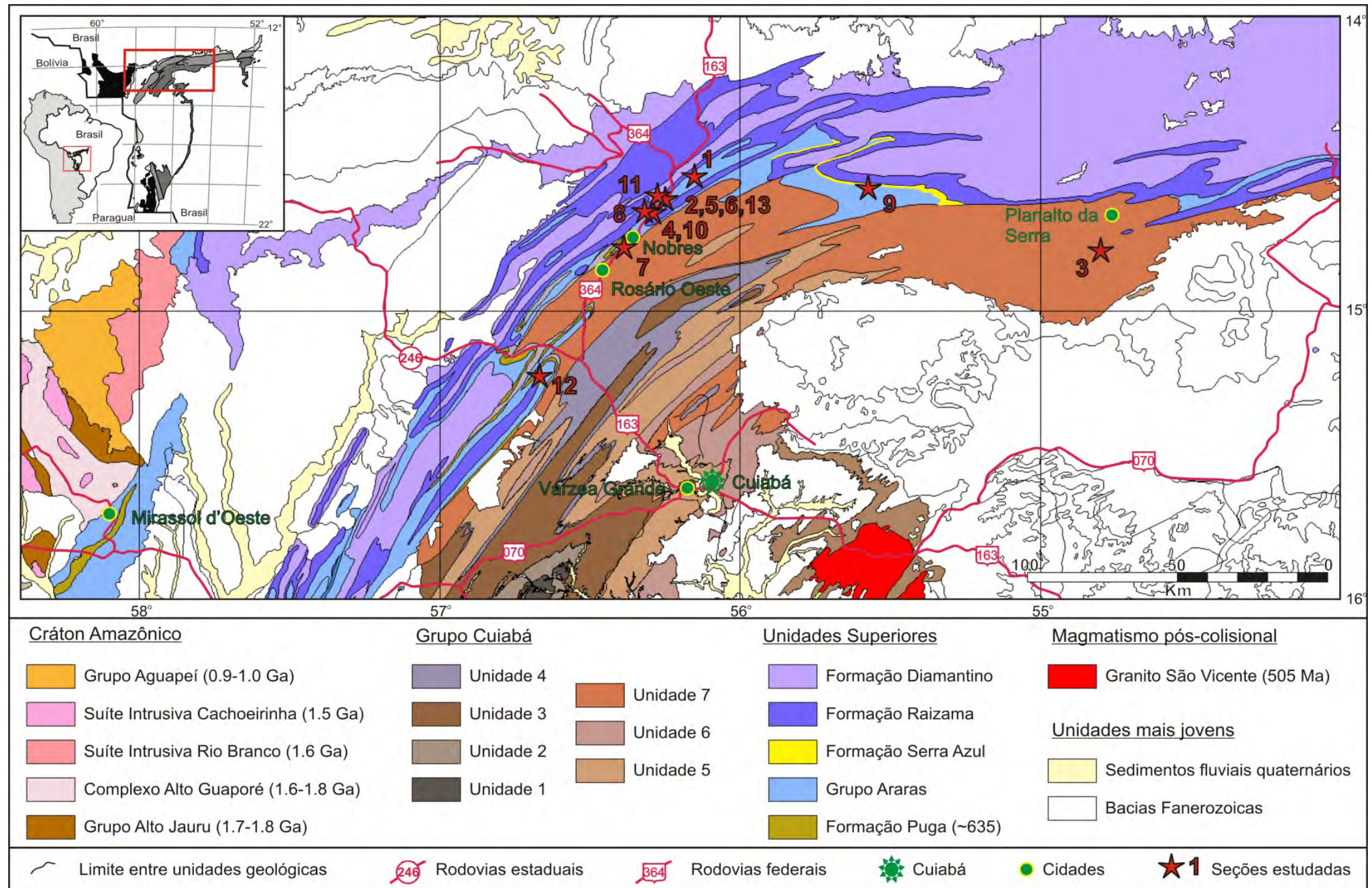

Figura 2. Mapa geológico regional da Faixa Paraguai em Mato Grosso (modificado de Schobenhaus et al., 2003), Folha SD-21, com a localização das seções estudadas. 


\subsubsection{Grupo Cuiabá}

O Grupo Cuiabá constitui a associação litológica mais antiga da FDP, de idade proterozóica (Almeida, 1967 e 1969), com seção basal ainda não conhecida. Constitui uma bacia de mar profundo depositada num ambiente tectonicamente ativo (Almeida 1964; Luz et al., 1980; Barros 1982) sob influência glacial (Alvarenga 1988 e 1990; Alvarenga e Trompette 1992 e 1993). Luz et al. (1980) no Projeto Coxipó descreveram detalhadamente, da base para o topo, oito subunidades que são apresentadas a seguir.

Subunidade 1 - constitui a porção mais basal hoje conhecida, composta de pelito, pelito sericítico (mais amplamente distribuídos) e arenitos. Seu contato de topo é gradacional para a subunidade 2.

Subunidade 2 - é constituída de arenitos arcosianos, arcóseos em espessos bancos, arenitos calcíferos, folhelhos grafitosos e calcários. Apresenta contato gradacional para a subunidade 3, além de contatos tectônicos.

Subunidade 3 - apresenta a maior diversidade litológica: pelitos, argilitos conglomeráticos, conglomerado, quartzo-arenitos, arenitos, arcóseos, calcários, margas calcíferas e folhelhos hematíticos. Contato gradacional e tectônico no topo com a subunidade 4.

Subunidade 4 - é constituída de conglomerados, pelitos e arenitos. Contato de topo e de base gradacionais e comumente de natureza tectônica.

Subunidade 5 - é constituída apenas por pelitos, pelitos sericíticos e microconglomerados, Apresenta contatos transicionais e tectônicos com as subunidades 3,4 e 7 .

Subunidade 6 - composta de argilitos conglomeráticos, arenitos, quartzoarenitos e calcários impuros. Seu contato com a subunidade 7 é transicional.

Subunidade 7 - constituído de paraconglomerados, pelitos e arenitos, numa espessura de 600 m. Faz contato gradacional com a subunidade 8 no Distrito de Guia.

Subunidade 8 - na denominada Sinclinal da Guia, é composta essencialmente de calcários e dolomitos, margas e pelitos sericíticos. 
De acordo com Silva (1999), as subunidades 1 e 2 propostas por Luz et al. (1980) para o Grupo Cuiabá correspondem à Unidade Inferior proposta por Alvarenga (1988) para a Faixa Paraguai. As subunidades 4, 6 e 7 (Luz et al., 1980) são correspondentes da Fácies Proximal da Unidade Média Turbidítica-Glaciogênica de Alvarenga (1988), depositadas no domínio interno da bacia por fluxos gravitacionais com influência glacial, situada na região do Distrito de Jangada, correlatas das formações Puga e Bauxi. As subunidades 3 e 5 (Luz et al., 1980) correspondem à Fácies Intermediária da Unidade Média Turbidítica-Glaciogênica (Alvarenga, 1988), enquanto que a subunidade 8 (Luz et al., 1980) estaria inserida na Unidade Média Carbonatada (Alvarenga, 1988) juntamente com o Grupo Araras.

\subsubsection{Formações Bauxi e Puga}

A litologia da Formação Bauxi é definida por diamictitos depositados sobre influência glacial, com clastos variados, intercalado por camadas de siltitos, quartzitos e conglomerados depositados sob influência glacial, posteriormente deformados. A passagem desta formação é lateral, sem evidências de discordância, para o Grupo Cuiabá e a Formação Puga. A área de maior exposição é no povoado de Bauxi e nas proximidades do vilarejo de Marzagão (Alvarenga, 1988).

A Formação Puga pode ser encontrada ao longo de toda a Faixa Paraguai, com uma litologia marcada pela presença de paraconglomerados petromíticos com matriz de natureza grauvaqueana argilo arenosa a mais grossa, com clastos distribuídos caoticamente pela matriz, sendo estes de vários tamanhos, podendo atingir até matacões, de arredondamento e composição variados (quartzo, sílex, feldspatos, calcários, granitos e rochas básicas). As rochas desta formação foram depositadas a partir de grandes geleiras, sendo posteriormente deformadas (Ribeiro Filho et al., 1975; Barros et al., 1982). A Formação Puga é correlacionada à Glaciação Marinoana por quimioestratigrafia isotópica (Nogueira et al., 2003; Alvarenga et al., 2004; Trindade et al., 2004). Uma idade $\mathrm{Pb}-\mathrm{Pb}$ de $627 \pm 32 \mathrm{Ma}$ foi obtida nos carbonatos de capa da Formação Mirassol d'Oeste (Babinski et al., 2006), confirmando a correlação quimioestratigráfica.

\subsubsection{Grupo Araras}

As rochas depositadas sob a influência da glaciação Marinoana (Formação Puga) são capeadas por cerca de $1300 \mathrm{~m}$ de carbonatos do Grupo Araras, que foi 
dividido em duas formações por Almeida (1964): Formação Guia, composta de aproximadamente $250 \mathrm{~m}$ de calcário e calcário argiloso laminados, sobreposta pela Formação Nobres com cerca de 1100 m de dolomitos de plataforma rasa (Figura 3).

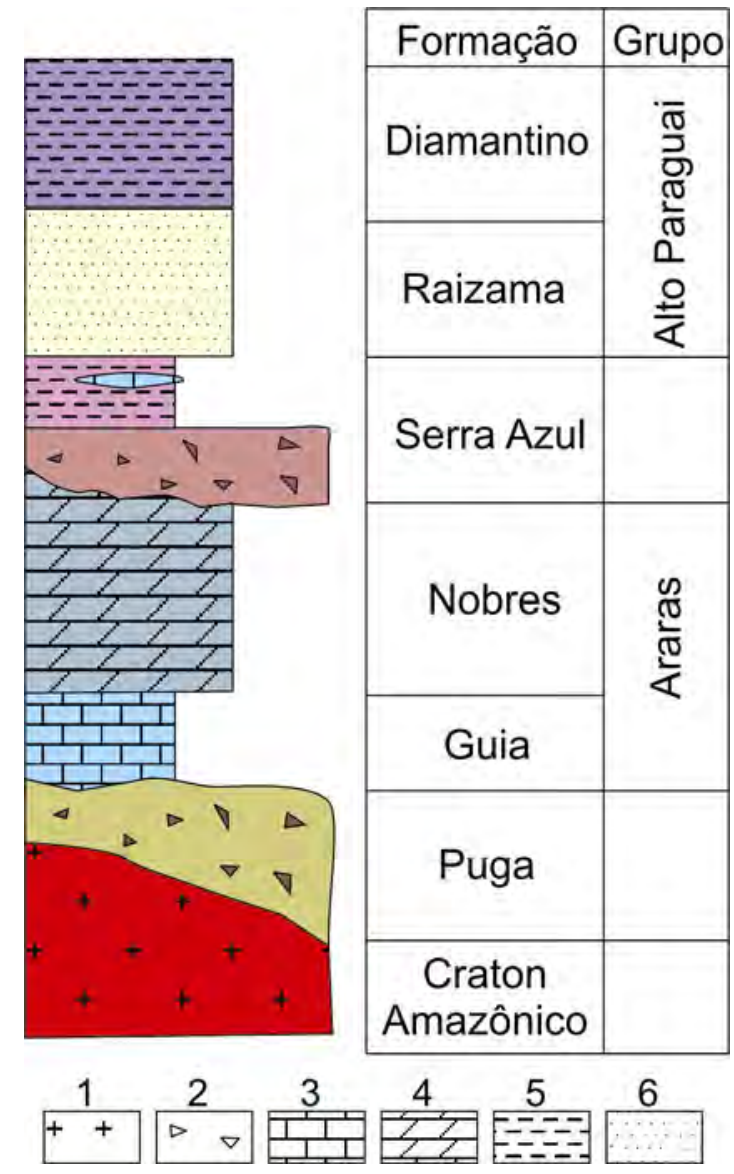

Figura 3. Coluna estratigráfica regional da FDP, proposta por Figueiredo (2006) para a zona plataformal. Litoestratigrafia: 1) embasamento cratônico, 2) diamictito, 3) calcário, 4) dolomito, 5) pelito e 6) arenito. À direita, detalhe das seções estudadas, indicando-se a posição estratigráfica das amostras analisadas

Alvarenga (1988) subdividiu a Faixa Paraguai em três unidades, das quais a Unidade Carbonatada Média abrange os calcários e dolomitos do Grupo Araras (até então considerada Formação Araras) e Fácies Guia (pertencente ao Grupo Cuiabá).

A Formação Araras foi também subdividida por Boggiani (1998) em Unidade Inferior Carbonatada Calcífera e Unidade Superior Carbonatada Dolomitica, composta por inúmeras fácies: maciça, oolítica, oncolítica, pisolítica, concreções magnesíferas, calcários betuminosos, estromatólitos, margas e brechas intraformacionais. O mesmo trabalho também correlaciona a Formação Araras e a Fácies Guia, definindo-as como não correlatas do Grupo Corumbá, constituído pelos carbonatos da porção sul da Faixa Paraguai, situados no estado de Mato Grosso do Sul. 
Nogueira (2003) propôs a reclassificação como Grupo Araras, conforme já havia proposto Almeida (1964), no entanto subdividindo-o em quatro formações que se seguem da base para o topo: Formação Mirassol do Oeste, Formação Guia, Formação Serra do Quilombo e Formação Nobres, estratigraficamente correlacionáveis respectivamente com o Grupo Corumbá (porção sul da Faixa Paraguai), composto pelas formações Cerradinho, Bocaina, Tamengo e Guaicurus, utilizando-se das estruturas estromatolíticas e curvas isotópicas de carbono, oxigênio e estrôncio (quimioestratigrafia isotópica). No entanto, Figueiredo (2006), utilizando as mesmas ferramentas isotópicas, correlaciona apenas a Formação Guia aos carbonatos da Formação Bocaina, enquanto que as Formações Tamengo e Guaicurus são consideradas mais jovens que toda a sucessão carbonática da porção norte da Faixa Paraguai.

Trabalhos anteriores assumiam uma idade Vendiana Superior (Zaine, 1991) para o Grupo Araras a partir de uma correlação com o Grupo Corumbá (Almeida, 1964), que contém fósseis da fauna Ediacara identificados por Fairchild (1978) e Walde et al. (1982). Porém, trabalhos mais recentes de quimioestratigrafia isotópica nos carbonatos da porção norte da Faixa Paraguai (Nogueira et al. 2003; Alvarenga et al., 2004; Figueiredo et al., 2005; Figueiredo et al., 2006b) propõem uma idade pós-Marinoana (Ediacarano inferior) para o Grupo Araras, enquanto que os dados geocronológicos em tufos da porção sul (Boggiani et al., 2005; Babinski et al., 2006) têm evidenciado que as rochas carbonáticas das porções norte e sul da Faixa Paraguai são distintas em termos geocronológicos, estando a Formação Tamengo situada no Ediacarano superior (545 \pm $6 \mathrm{Ma}$; Boggiani et al., 2005).

A descrição das formações do Grupo Araras a seguir obedecerá à classificação de Nogueira \& Riccomini (2006), por ser a mais recente e detalhada. No entanto, é importante ressaltar que a Formação Mirassol d'Oeste, como descrita, não ocorre nas zonas dobradas da Faixa Paraguai e que na área de estudo não se individualizou a Formação Serra do Quilombo, pela dificuldade em reconhecê-la em campo.

\subsubsection{Formação Mirassol d'Oeste}

A Formação Mirassol d'Oeste está depositada diretamente sobre os diamictitos da Formação Puga e se restringe ao domínio não deformado da Faixa Paraguai. Sua composição é essencialmente dolomítica, com as rochas apresentando cor rósea e 
estruturas sedimentares como estromatólitos, mega ripples e tubestones (Nogueira \& Riccomini, 2006). Possui cerca de $30 \mathrm{~m}$ e apresenta contatos bruscos com as formações Puga, com lobos de sobrecarga (Nogueira et al., 2003), e Guia. Nogueira et al. (2003) a correlacionaram com as capas carbonáticas marinoanas, sugerindo uma rápida deposição durante a transgressão marinha na plataforma.

\subsubsection{Formação Guia}

A Formação Guia constitui a porção inferior do Grupo Araras, de composição predominantemente pelítica-calcárea (Almeida, 1964; Hennies, 1966; Alvarenga, 1990). Esta formação encontra-se sobreposta à Formação Mirassol d'Oeste na zona indeformada da Faixa Paraguai (Nogueira e Riccomini, 2006) e aos diamictitos da Formação Puga (Almeida, 1964) e sotoposta aos dolomitos da Formação Serra do Quilombo (Nogueira \& Riccomini, 2006) e aos dolomitos da Formação Nobres (Almeida, 1964).

Sua deposição se inicia com cerca de 20 m de dolomito róseo (Alvarenga, 1990), passando bruscamente para cerca de $240 \mathrm{~m}$ de calcários maciços ou apresentando laminação plano-paralela, ritmicidade, lâminas de argila, ocorrência de folhelhos intercalados e de margas (Alvarenga, 1990; Ganzer \& Figueiredo, 2004; Figueiredo, 2006; Nogueira e Riccomini, 2006). Estas litofácies refletem uma plataforma moderadamente profunda a profunda (Nogueira, 2003).

\subsubsection{Formação Serra do Quilombo}

A Formação Serra do Quilombo foi identificada e individualizada do restante da Formação Nobres por Nogueira e Riccomini (2006), constituindo cerca de 150 m de dolarenitos, brechas suportadas por matriz e brechas cimentadas por doloesparita. Seu ambiente foi interpretado como de plataforma rasa a moderadamente profunda e talude, saturada em carbonato e influenciada, inicialmente, por sismos e, posteriormente, dominada por tempestades.

\subsubsection{Formação Nobres}

A Formação Nobres constitui a porção superior do Grupo Araras e tem composição predominantemente dolomítica (Almeida, 1964; Hennies, 1966; Alvarenga, 1990). Esta formação é estratigraficamente sobreposta aos dolomitos da Formação Serra do Quilombo e sotoposta aos arenitos da Formação Raizama (Nogueira \& 
Riccomini, 2006). Porém, na área de estudo é considerada como sobreposta aos calcários da Formação Guia e sotoposta aos diamictitos da Formação Serra Azul (Figueiredo et al., 2005a, 2006a).

Esta unidade inicia com a deposição de dolomito maciço a laminado, passando a brecha dolomítica contendo clastos de ritmito da Formação Guia e de dolomito oolítico, camadas de arcóseo intercaladas, dolomito parcialmente a completamente silicificado, pelito laminado e estruturas sedimentares produzidas por ondas (hummocky) e correntes (herring bone), oólitos, estromatólitos dômicos, colunares e estratiformes e colunares (Figueiredo, 2006). Nogueira e Riccomini (2006) desconsideram como pertencentes a esta formação as brechas dolomíticas e interpretam o ambiente como uma planície de maré árida e tipo sabkha.

\subsubsection{Formação Serra Azul}

A Formação Serra Azul aqui descrita segue os trabalhos de Figueiredo (2006) e Alvarenga et al. (2007). Um maior detalhamento estratigráfico e sedimentológico desta formação foi realizado durante esta tese de doutoramento e publicado por Figueiredo et al. (2008), cujo artigo se encontra no corpo da tese.

Esta formação sobrepõe os dolomitos da Formação Nobres e está sotoposta aos conglomerados e arenitos da Formação Raizama (Figura 3), sendo composta por uma espessa sucessão $(250$ a $300 \mathrm{~m})$ de diamictitos recobertos por siltitos, com intercalações de arenitos finos no topo, descritos adiante. Sua exposição é restrita, pois geralmente se encontra coberta por depósitos de talus recentes, provenientes da alteração dos arenitos da Formação Raizama, que sustentam as serras dessa região.

A unidade mais basal possui uma espessura em torno de $70 \mathrm{~m}$ e está depositada sobre a Formação Nobres (Figura 3), no entanto seu contato basal não foi observado. É constituída basicamente de diamictito maciço a pobremente estratificado, com abundante matriz silto-argilosa vermelha contendo clastos variegados na composição, tamanho e forma, dispersos na matriz. Embora seu contato basal não esteja exposto, a presença de fragmentos de carbonatos e chert da Formação Nobres sugere que seja erosivo. O contato superior com a unidade pelítica de topo é concordante e brusco. 
A unidade de topo possui cerca de $200 \mathrm{~m}$ de siltito, inicialmente vermelho laminado, com esparsos grânulos, que grada para argilito cinza rítmico, onde são encontradas lentes de carbonato intercaladas em alguns locais. No topo se observam intercalações de camadas de espessuras decimétricas de arenito muito fino, com estratificação plano-paralela, hummucky e bandamentos de maré, que se tornam cada vez mais freqüentes e mais espessas em direção ao topo. O contato de topo com os conglomerados e arcóseos da Formação Raizama foi inicialmente interpretado como brusco (Alvarenga et al., 2007), porém um maior detalhamento mostrou que é gradacional (Figueiredo et al., 2008).

\subsubsection{Grupo Alto Paraguai}

A unidade superior da Faixa Paraguai consiste das rochas siliciclásticas do Grupo Alto Paraguai, dividido em duas formações geológicas: Formação Raizama e Formação Diamantino (Figura 3).

\subsubsection{Formação Raizama}

A Formação Raizama é composta de arenito ortoquartzítico conglomerático, intercalado com camadas de arenito arcoseano fino a grosso, com estratificações cruzadas e marcas de onda, siltito e folhelho (Ribeiro Filho et al., 1975), depositados em águas epineríticas, pouco profundas, e ambiente dominado por marés, durante subsidência lenta e contínua (Almeida, 1964).

Tanto o contato basal com a Formação Serra Azul Figueiredo et al., 2008), quanto o contato superior com a Formação Diamantino (Alvarenga, 1984) são gradacionais.

\subsubsection{Formação Diamantino}

A Formação Diamantino é composta pela intercalação de arcóseo fino, siltito e folhelho, finamente estratificados, calcíferos e intercalados por bancos de arcóseo, mostrando estratificações cruzadas de pequeno porte e marcas de ondas (Alvarenga 1984), depositados durante o soerguimento de porções mais a sudeste, gerando a inversão da bacia precursora para uma bacia sucessora com influência marinha e continental tipo molassa (Hennies, 1966). 
O contato inferior é gradacional e o superior ocorre por discordância erosiva angular com as rochas fanerozoicas do Grupo Parecis ( Alvarenga 1984).

\subsection{EVOLUÇÃO GEOTECTÔNICA}

O contexto geológico do Estado de Mato Grosso, encerra três domínios tectônicos: (i) Cráton Amazônico a leste e noroeste do estado, (ii) Faixa de Dobramentos Paraguai, seguimento norte, soerguida na borda sul-sudeste deste mesmo cráton, e (iii) as sucessões sedimentares da Bacia do Paraná (a sudeste), Grupo Parecis (a norte) e Formação Pantanal e aluviões recentes (a sudoeste e oeste). As descrições aqui apresentadas se aterão ao domínio tectônico da Faixa Paraguai.

A Faixa Paraguai (Almeida 1974, 1984) corresponde a um cinturão móvel de traçado convexo, edificado às margens S-SE do Cráton Amazônico durante o Neoproterozoico e o Cambriano Médio. Vários trabalhos de síntese do conhecimento deste cinturão móvel (Almeida, 1984; Alvarenga, 1990; Alvarenga \& Trompette 1993; Trompette, 1994; Alvarenga, 2000) convergem para um modelo de compartimentação da deformação e metamorfismo, que ressalta o incremento destes parâmetros da zona externa do cinturão (Domínio de Cobertura de Antepaís) para a zona interna (Domínio Tectônico Interno). As características geológicas identificadoras dos domínios tectônicos da Faixa Paraguai, no sentido empregado por Ruiz et al. (1999), serão apresentados resumidamente a seguir.

\subsubsection{Coberturas de Antepaís}

As coberturas de Antepaís são constituídas pelas formações Bauxi, Puga, Araras, Raizama e Diamantino, que recobrem, em discordância angular e erosiva, vastos trechos do embasamento pré-brasiliano. Estas rochas exibem extensas áreas de estratos sedimentares sub-horizontalizados a levemente basculados, sem vestígios de metamorfismo e deformação dúctil penetrativa.

\subsubsection{Domínio Tectônico Externo}

Este domínio é formado pelas mesmas unidades litoestratigráficas que recobrem o antepaís mais a recente unidade encontrada, Formação Serra Azul. Todavia, neste domínio as rochas registram importante tectônica compressiva responsável pela fase orogênica do cinturão. O metamorfismo é incipiente ou ausente, a deformação é 
dominada por dobras regionais simétricas a levemente assimétricas, com expressivas superfícies de movimentos reversos em direção ao Cráton Amazônico. Falhas de rasgamento, sub-ortogonais às falhas com mergulhos íngremes, recortam transversamente esse domínio

\subsubsection{Domínio Tectônico Interno}

Neste domínio encontram-se os metassedimentos do Grupo Cuiabá (Luz et al., 1980, Barros et al., 1982) e a Seqüência Vulcano-sedimentar de Nova Xavantina (Pinho, 1990; Martinelli, 1999), que mostram metamorfismo na fácies xisto-verde, evolução estrutural polifásica, onde se destacam dobras regionais inversas ou recumbentes associadas a superfícies de cavalgamentos com notável transporte para S ou SE, no sentido oposto ao antepaís, Silva (1999) descreveu um arranjo em leque das dobras e foliação da principal fase de deformação (Dn) do domínio interno.

Diversos trabalhos de geologia regional tem destacado a ocorrência de maciços graníticos e, mais raramente, produtos vulcânicos vinculados à evolução do Domínio Interno do Cinturão Paraguai (Almeida, 1964; Luz et al., 1980; Barros et al., 1982; Del'Arco et al., 1982; Ruiz et al. 1999).

Essa importante manifestação magmática é representada em Mato Grosso pelo granito pré-colisional Araguaiana (idade U-Pb $604 \mathrm{Ma}$ ) e pelos granitos tardi a póscolisionais Lajinha (idade U-Pb $509 \mathrm{Ma}$ ) e São Vicente (idade U-Pb $521 \pm 8 \mathrm{Ma}$ ). As idades citadas são de Ferreira (2009). Uma idade Ar-Ar obtida em biotitas, da Zona de Cisalhamento Araés, forneceram uma idade de resfriamento de $541 \pm 0,7 \mathrm{Ma}$. Dados isotópicos U-Pb (Pinho et al., dados inéditos) tem indicado que as Vulcânicas de Mimoso (Barros et al., 1982), tradicionalmente consideradas como co-genéticas ao granito São Vicente, retratam um evento magmático mais novo (Cretáceo), sem qualquer vínculo com a Orogenia Brasiliana. 



\section{CAPÍTULO 2 MATERIAIS E MÉTODOS}

Neste capítulo estão descritos os procedimentos utilizados na aquisição de dados sobre a Faixa Paraguai Norte, incluindo trabalhos de campo, petrografia, geoquímica e geologia isotópica ( $\mathrm{C}, \mathrm{O}, \mathrm{S}, \mathrm{Sr}-\mathrm{Sr}, \mathrm{Pb}-\mathrm{Pb}, \mathrm{K}-\mathrm{Ar}$ e $\mathrm{Sm}-\mathrm{Nd}$ ), dando-se especial enfoque ao novo procedimento de extração para análises isotópicas de enxofre.

\subsection{TRABALHOS DE CAMPO}

Os trabalhos de campo foram realizados em quatro etapas, totalizando 43 dias em campo e 550 amostras coletadas em vários afloramentos isolados (viagens de reconhecimento regional), ao longo de perfis sistemáticos e de furos de sondagem. As seções estratigráficas estudadas (7 perfis e 4 furos) foram descritas em detalhe e amostradas em nível de detalhe, conforme as condições de exposição e recuperação permitiram. As amostras coletadas $(50 \mathrm{~g} \mathrm{a} 6 \mathrm{~kg}$ ) foram armazenadas individualmente em sacos plásticos.

\subsection{PETROGRAFIA}

O estudo petrográfico foi realizado inicialmente através da descrição macroscópica das amostras de mão e fatias a olho nu e com auxílio de lupa de mão. Numa segunda etapa, as amostras foram laminadas e descritas sob o microscópio petrográfico Olympus BX-40, servindo a duas finalidades, a caracterização das diferentes microfácies e a seleção de amostras não alteradas para coleta de microamostras destinadas às análises isotópicas de C, O e Sr.

Posteriormente, este procedimento de seleção de amostras foi alterado, substituindo-se o uso de seções delgadas por amostras fatiadas e polidas descritas sob uma lupa binocular. As vantagens desta mudança são: (i) menores custo e tempo de preparação; (ii) ampliação do campo de visão da geometria de lâminas/camadas e de micro-seqüência de fácies; e (iii) manutenção da qualidade da seleção das micro- 
amostras, podendo-se reconhecer estilólitos, microfaturas, microvenulações e recristalizações que devem ser evitados na micro-amostragem (Kaufman \& Knoll, 1995). No entanto, ainda se faz necessário o uso de seções delgadas no reconhecimento da mineralogia de terrígenos, nas frações argila e silte, e na determinação do conteúdo de micrita, microesparita e cimento presentes.

Foram confeccionadas 151 seções delgadas de carbonatos, diamictito, clastos recuperados de diamictito e pelitos, no Laboratório de Laminação do Instituto de Geociências, Universidade de São Paulo. Foram cortadas e polidas 100 amostras, parte nos Rock Cutting e Isotope Chemistry Laboratories, da Maryland University, Estados Unidos, e parte no Laboratório de Preparação de Amostras, com ferramental do Laboratório de Sistemas Cársticos, do Instituto de Geociências, Universidade de São Paulo.

\subsection{GEOQUÍMICA}

A geoquímica (inorgânica) das rochas carbonáticas deste trabalho, associada à petrografia, tem como finalidade fornecer parâmetros químicos aplicáveis ao reconhecimento do ambiente deposicional e às alterações pós-deposicionais ocorridas.

Para o estudo geoquímico elementar, foram determinados os teores dos elementos maiores $\mathrm{Si}, \mathrm{Al}, \mathrm{K}, \mathrm{P}, \mathrm{Mn}, \mathrm{Na}, \mathrm{Fe}, \mathrm{Mg}$ e Ca e traços $\mathrm{Rb}$ e Sr em 57 amostras de carbonatos por Fluorescência de Raios-X, preparadas no Laboratórios de Química e analisadas no Laboratório de Fluorescência de Raios-X do Instituto de Geociências, Universidade de São Paulo.

\subsubsection{Geoquímica Elementar}

Para determinação dos teores dos elementos químicos maiores ( $\mathrm{Si}, \mathrm{Al}, \mathrm{K}, \mathrm{P}, \mathrm{Mn}$, $\mathrm{Na}, \mathrm{Fe}, \mathrm{Mg}$ e $\mathrm{Ca}$ ) foram confeccionadas pastilhas de vidro através da fusão de $1 \mathrm{~g}$ de amostra pulverizada e $9 \mathrm{~g}$ de fundente, aquecidos a $1000^{\circ} \mathrm{C}$, em cadinhos de platina. As pastilhas foram analisadas no Espectrômetro de Raios-X Philips PW 2510 do Laboratório do Departamento de Mineralogia e Geotectônica do IGc, USP.

Para análise dos elementos traços $\mathrm{Rb}$ e $\mathrm{Sr}$, cerca de $10 \mathrm{~g}$ de amostra pulverizada foi colocada em cadinhos plásticos com fundo de Mailler e compactada. Os teores também foram obtidos no Espectrômetro de Raios-X Philips PW 2510. 


\subsection{GEOLOGIA ISOTÓPICA}

O estudo de sucessões não fossilíferas leva ao inevitável uso de outras ferramentas de correlação e datação. A estas aplicações, servem algumas metodologias isotópicas, tendo-se aplicado isótopos estáveis e radiogênicos (C, O, S e Sr) na correlação estratigráfica e no estudo paeloambiental e climático. As idades absolutas foram obtidas através da aplicação dos métodos radiométricos $\mathrm{Pb}-\mathrm{Pb}, \mathrm{K}-\mathrm{Ar}$ e Sm-Nd.

\subsubsection{Análise de isótopos estáveis}

As análises isotópicas de $\mathrm{C}$ e $\mathrm{O}$ foram obtidas no Laboratório de Isótopos Estáveis do Centro de Pesquisas Geocronológicas (CPGeo), do Instituto de Geociências (IGc) da USP, enquanto as análises isotópicas de $\mathrm{C}$ orgânico e $\mathrm{S}$ foram obtidas durante estágio de doutorado no exterior (CNPq 200186/2008-6), sob a supervisão do professor Dr. Alan Jay Kaufman, nos laboratórios da Maryland University, Estados Unidos: Modeling Laboratory, Stable Isotope Chemistry Laboratory e Mass Spectometry Facilities.

\subsubsection{Análises isotópicas de C e O}

As análises dos isótopos estáveis de carbono e oxigênio em carbonatos foram obtidas simultaneamente através da reação de $50 \mathrm{mg}$ da amostra pulverizada com $\mathrm{H}_{3} \mathrm{PO}_{4} 100 \%$, em vácuo, a $25^{\circ} \mathrm{C}$ por 24 horas (McCrea, 1950). O $\mathrm{CO}_{2}$ liberado é purificado numa linha de extração de ultra-vácuo com dois loopings imersos, o primeiro, numa mistura de álcool $+\mathrm{N}_{2}$ e, o segundo, apenas em $\mathrm{N}_{2}$. Após a purificação, o $\mathrm{CO}_{2}$ é extraído para ampolas, cujas razões ${ }^{13} \mathrm{C} /{ }^{12} \mathrm{C}$ e ${ }^{18} \mathrm{O} /{ }^{16} \mathrm{O}$ foram obtidas num espectrômetro de massa Europa Geo 20-20.

Com a aquisição do espectrômetro de massas Delta ${ }^{\text {PLUS }}$ Advantage, pelo CPGeo em 2008, todo o procedimento off-line passou a ser realizado on-line. Cerca de $100 \mu \mathrm{g}$ de amostra pulverizada foram colocados em ampolas seladas, posteriormente dispostas na bandeja do Gas Bench II, uma bandeja robótica de preparação de fluxo contínuo com sistema de injeção automatizado, acoplada ao espectrômetro de massas. A migração para o procedimento on-line se deu após a comprovação da reprodutibilidade dos resultados, mediante a re-análise de 14 micro-amostras arquivadas, previamente analisadas no procedimento off-line. 
Os valores $\delta^{13} \mathrm{C}$ são apresentados em per mil (\%) com base no padrão Vienna Pee Dee Belemnite (V-PDB; $\delta^{13} \mathrm{C}=\left[\left(\mathrm{C}^{13} / \mathrm{C}^{12}\right.\right.$ amostra $-\mathrm{C}^{13} / \mathrm{C}^{12}$ padrão $) / \mathrm{C}^{13} / \mathrm{C}^{12}$ padrão $] \times 10^{3}$. A precisão para as análises é de cerca de 0,05\% para C e de 0,07\% para 0 .

\subsubsection{Extração e análise isotópica de C orgânico em carbonatos}

A abundância de C orgânico (ou carbono orgânico total, COT) e os valores de $\delta^{13} \mathrm{C}_{\text {org }}$ foram determinados seguindo os procedimentos descritos por Kaufman et al. (2007). Aproximadamente $1 \mathrm{~g}$ de rocha total pulverizada foi pesada e dissolvida em $\mathrm{HCl}$ $6 \mathrm{~N}$, dentro de tubos de centrífuga de polipropileno, com capacidade de $15 \mathrm{ml}$. Os resíduos foram lavados com água Milli Q, centrifugados, isolados, secados e pesados para determinar a abundância de carbonato nas amostras. Microamostras do resíduo foram pesadas (de $500 \mu \mathrm{g}$ a $5 \mathrm{mg}$, de acordo com o teor de matéria orgânica) em cadinhos de estanho e as razões isotópicas foram medidas no espectrômetro de massas Micromass Isoprime de fluxo contínuo. O COT foi calculado a partir da porcentagem de carbonato e da abundância medida de C nos resíduos, quantificados por um analisador elemental (AE) relativo ao padrão uréia. Os valores $\delta^{13} C_{\text {org }}$ são apresentados em per mil (\%o) com base no padrão $\mathrm{V}$-PDB $\left(\delta^{13} \mathrm{C}=\left[\left(\mathrm{C}^{13} / \mathrm{C}^{12}\right.\right.\right.$ amostra $C^{13} / C^{12}$ padrão) $/ C^{13} / C^{12}$ padrão] $\times 10^{3}$. O erro analítico para as análises de COT é de $0,12 \%$ e para $\delta^{13} C_{\text {org }}$ é de $0,5 \%$.

\subsubsection{Extração e análise isotópica de S}

O enxofre dos carbonatos foi extraído em duas fases, da fase reduzida nos sulfetos e da fase oxidada associada aos carbonatos, conforme seguem descrições detalhadas.

\subsection{Extração de de Sulfetos}

Para determinar as concentrações e composições isotópicas de sulfetos (pirita), o enxofre foi extraído utilizando o método de redução por cromo (CRS: Chromium Reducible Sulfur; Canfield et al., 1986; Goldberg et al., 2005). Cerca de 5 a $10 \mathrm{~g}$ de amostra pulverizada foram acidificados com $\mathrm{HCl} 6 \mathrm{~N}$ para remoção dos carbonatos presentes. A acidificação se deu concomitante à filtragem sob vácuo para evitar a oxidação dos sulfetos pelo contato prolongado com $\mathrm{HCl}$ (Marenco et al., 2008). O resíduo foi diluído em $25 \mathrm{ml}$ de solução reduzida de $\mathrm{CrCl}_{2} 1 \mathrm{M}$, em atmosfera de $\mathrm{N}_{2}$. O $\mathrm{H}_{2} \mathrm{~S}$ produzido foi borbulhado através de uma armadilha de $15 \mathrm{ml}$ de $\left(\mathrm{CH}_{3} \mathrm{CO}_{2}\right)$ 
$2 \mathrm{Zn} .2 \mathrm{H}_{2} \mathrm{O} 1 \mathrm{M}$ e precipitado como $\mathrm{ZnS}$. O ZnS foi convertido para $\mathrm{Ag}_{2} \mathrm{~S}$ por troca iônica, adicionando-se $4 \mathrm{ml}$ de $\mathrm{AgNO}_{3}$ 0,3 $\mathrm{M}$. O Ag $2 \mathrm{~S}$ obtido foi centrifugado, lavado com $\mathrm{NH}_{4}$ $1 \mathrm{M}$, para dissolução de cristais de acetato, e água milli $\mathrm{Q}$, secado e pesado. As concentrações de CRS (equivalente ao conteúdo total de $S$ na pirita) são calculadas estequiometricamente, em relação ao peso final de $\mathrm{Ag}_{2} \mathrm{~S}$ obtido e às razões isotópicas medidas por espectrometria de massas com analisador elemental (AE) acoplado.

Em virtude de amostras importantes possuírem concentrações muito baixas de sulfeto, o procedimento foi modificado para permitir a obtenção de quantidades suficientes de sulfeto para análise isotópica. A utilização de grande quantidade de amostra, cerca de $200 \mathrm{~g}$, inviabilizou a acidificação sob vácuo. Assim, utilizaram-se os resíduos das extrações de sulfatos, após acidificação e secagem (detalhada a seguir), para extração dos sulfetos. Outra modificação foi a substituição da solução amadilha de acetato de zinco por uma solução de nitrato de prata ácida, a fim de eliminar as etapas de lavagem com solução de amônia, responsável por pequenas perdas de cristais de sulfeto de prata, cruciais quando se trabalha com baixos teores.

\subsection{Extração de Sulfatos}

As análises isotópicas de enxofre nos carbonatos (CAS: Carbonate Associated Sulfur) seguiram os procedimentos descritos por Goldberg et al. (2005). Cerca de $200 \mathrm{a}$ $350 \mathrm{~g}$ de amostra pulverizada foi lixiviada por $24 \mathrm{~h}$, com uma solução de $\mathrm{NaCl}$ (10\%), e filtrada duas vezes, a primeira com filtro de papel de $30 \mathrm{~cm}$, para separar o resíduo da solução com sulfato solúvel, e a segunda com membrana de nitrato de celulose 0,45 $\mu \mathrm{m}$, para remover todas as partículas sólidas da solução lixiviada. Para verificação do sulfato solúvel presente, adicionou-se à solução lixiviada $30 \mathrm{ml}$ de $\mathrm{BaCl}_{2}$ (16\%), deixando descansar por $24 \mathrm{~h}$. Em caso de precipitação de $\mathrm{BaSO}_{4}$, repetiu-se 0 procedimento de lixiviação até não mais precipitar finos cristais de sulfato visíveis, ou até o quinto lixiviado. Os cristais de $\mathrm{BaSO}_{4}$ foram filtrados com membrana de nitrato de celulose $0,45 \mu \mathrm{m}$ previamente pesada, lavados com água Milli $\mathrm{Q}$, secos e pesados. $\mathrm{A}$ quantidade de sulfato presente foi calculada por estequiometria e os cristais foram utilizados para obtenção das razões isotópicas dos sulfatos secundários (associados aos carbonatos).

O resíduo lixiviado foi acidificado, dentro de duplo filtro de papel, por gotejamento lento de 400 a $800 \mathrm{ml}$ de $\mathrm{HCl}$ (25\%), dependendo da quantidade de 
carbonato presente em cada amostra. A acidificação se deu dentro do próprio filtro para evitar a oxidação da pirita presente, pelo contato prolongado com o ácido. O resíduo foi lavado com água milli $\mathrm{Q}$, secado e pesado para quantificação dos carbonatos dissolvidos, enquanto que a solução foi novamente filtrada com membrana de nitrato de celulose $0,45 \mu \mathrm{m}$ para remoção completa das partículas sólidas. À solução ácida foram adicionados $30 \mathrm{ml}$ de $\mathrm{BaCl}_{2}(16 \%)$, deixando descansar por 3 dias, para precipitação de $\mathrm{BaSO}_{4}$. A solução foi então filtrada com membrana de nitrato de celulose $0,45 \mu \mathrm{m}$ previamente pesada, para a recuperação dos cristais de $\mathrm{BaSO}_{4}$, que foram lavados com água milli $\mathrm{Q}$, secos e pesados. Os cristais foram destinados à análise isotópica; a determinação do teor de sulfato traço relacionado aos carbonatos da amostra foi calculado por estequiometria.

\subsection{Análise Isotópica de S}

Os extratos de sulfato e sulfeto preparados foram pesados (150 a $170 \mu \mathrm{g}$ de $\mathrm{BaSO}_{4}$ e 120 a $140 \mu \mathrm{g}$ de $\mathrm{Ag}_{2} \mathrm{~S}$ ) dentro de cadinhos de estanho, adicionando-se $\mathrm{V}_{2} \mathrm{O}_{5}$ na proporção 1:2 (amostra/ $\mathrm{V}_{2} \mathrm{O}_{5}$ ). Os cadinhos foram fechados e submetidos à combustão a $1030{ }^{\circ} \mathrm{C}$, num analisador elemental (EA) Eurovector, para separação do $\mathrm{SO}_{2}$, cujas razões isotópicas de $\mathrm{S}$ foram medidas no espectrômetro de massa Micromass Isoprime acoplado. Os valors são apresentados em per mil (\%) em relação ao padrão Vienna Canyon Diablo Troilite (VCDT). Os respectivos erros analíticos são de $0,3 \%$ e $0,2 \%$.

\subsubsection{Análise isotópica de $\mathrm{Sr}$}

As razões isotópicas de estrôncio foram obtidas no Centro de Pesquisas Geocronológicas da Universidade de São Paulo, através da reação de ca. 100 mg de carbonato pulverizado com $2 \mathrm{ml}$ de $\mathrm{HCl} 0,1 \mathrm{~N}$ por 1 hora. Retirado o sobrenadante, a amostra foi centrifugada e lavada três vezes com água bidestilada, obtendo-se o primeiro lixiviado, que foi desprezado. A amostra foi seca, novamente adicionados $2 \mathrm{ml}$ de $\mathrm{HCl} 1 \mathrm{~N}$ e deixado reagir por 30 minutos. A amostra foi centrifugada e lavada três vezes, obtendo-se o segundo lixiviado. O estrôncio do segundo lixiviado foi separado dos demais elementos através da técnica de troca iônica, em colunas com resina $\mathrm{Sr}$ Spec. Suas composições isotópicas foram determinadas no espectrômetro de massa Finnigan MAT 262. As razões ${ }^{87} \mathrm{Sr} /{ }^{86} \mathrm{Sr}$ obtidas no padrão NBS 987 neste equipamento 
apresentam um valor médio de 0,710240 \pm 0,00008. O branco analítico do laboratório é de ca. 4 ng.

\subsubsection{Análises geocronológicas}

Os isótopos de $\mathrm{Pb}$ foram utilizados para obter idades isocrônicas dos carbonatos estudados. Idades K-Ar foram determinadas em clastos de rochas vulcânicas recuperados dos diamictitos, que forneceram idades máximas de deposição. As idades modelo $\left(T_{\mathrm{DM}}\right)$ Sm-Nd foram obtidas nas rochas terrígenas e forneceram informações sobre as áreas-fonte dos sedimentos. Todas estas análises foram realizadas no CPGeo do IGc, USP.

\subsubsection{Análise de isótopos de Pb em carbonatos}

As análises isotópicas de $\mathrm{Pb}$ em carbonatos foram realizadas no Centro de Pesquisas Geocronológicas da Universidade de São Paulo e seguiram os procedimentos descritos por Babinski et al. (1999). As amostras de carbonatos foram trituradas e os fragmentos (ca. 1-2 mm) lavados 3 vezes com água Milli Q em ultrasom, para remoção da poeira, e secados. Com auxílio de uma lupa binocular foram removidos os grãos que apresentavam vênulas ou alterações. Cerca de 500 mg de amostra foi lixiviada em duas etapas. Na primeira etapa, adicionou-se $2 \mathrm{ml}$ de $\mathrm{HBr} 0,7 \mathrm{~N}$ à amostra, deixando reagir por duas horas, para obtenção do primeiro lixiviado (L1). Em seguida o L1 foi descartado e a amostra lavada com água Milli Q e seca. Na segunda etapa, adicionou-se $10 \mathrm{ml}$ de $\mathrm{HBr} 0,7 \mathrm{~N}$ à amostra, reagindo por 12 horas, para obtenção do segundo lixiviado (L2). Somente o L2 obtido foi submetido à purificação de $\mathrm{Pb}$ através da técnica de troca iônica, sendo posteriormente depositado em filamento de rênio para a determinação das composições isotópicas de $\mathrm{Pb}$, utilizando o espectrômetro de massa Finnigan MAT 262. O fracionamento isotópico foi corrigido através de análises de padrões de Pb NBS 981, que apresentaram razões ${ }^{206} \mathrm{~Pb} /{ }^{204} \mathrm{~Pb}$ de $16,900 \pm 0,007,{ }^{207} \mathrm{~Pb} /{ }^{204} \mathrm{~Pb}$ de $15.442 \pm 0.019$ e ${ }^{208} \mathrm{~Pb} /{ }^{204} \mathrm{~Pb}$ de $36.545 \pm 0.026$, no período das análises. O branco analítico de $\mathrm{Pb}$ foi ca. $34 \mathrm{pg}$. As idades foram determinadas através do software Isoplot (Ludwig, 1999).

\subsubsection{Extração e Análise isotópica de K-Ar em clastos}

As amostras de clastos vulcânicos tiveram suas partes externas retiradas, sendo o núcleo inalterado de cada amostra britado e peneirado, obtendo-se uma fração com 
granulometria entre 0,42 e 0,250 $\mathrm{mm}$. Metade desta fração foi pulverizada em almofariz de ágata para análise de $\mathrm{K}$, enquanto que a fração mais grossa foi destinada à determinação de Ar.

No procedimento para determinação do K, a amostra foi pesada em béquer de teflon Savillex ${ }^{\circledR}$ e dissolvida com $\mathrm{H}_{2} \mathrm{SO}_{4}, \mathrm{HF}$ e $\mathrm{HNO}_{3}$, sob processos de aquecimento brandos e severos. A solução obtida foi filtrada, uma solução de lítio (Li) foi adicionada e a solução final foi analisada no fotômetro de chama Micronal B462.

Para a determinação do Ar, 0,6 g de amostra foi pesada em cadinho de molibdênio. A extração do Ar é realizada através de fusão, em forno de indução acoplado à linha de extração de ultra-alto-vácuo, com purificação do gás em duas etapas. A primeira se deu através de reações de oxi-redução com cobre metálico, óxido de cobre a $450^{\circ} \mathrm{C}$ e zeólita (dessecante). Na segunda etapa, o gás foi submetido à reação de absorção com titânio metálico a $800^{\circ} \mathrm{C}$, seguido de resfriamento até a temperatura ambiente. A amostra purificada foi coletada em ampola e analisada em espectrômetro de massas de fonte gasosa tipo Reynolds.

\subsubsection{Análise isotópica $\mathrm{Sm}-\mathrm{Nd}$ em rochas sedimentares}

As razões isotópicas de samário e neodímio foram obtidas em 32 amostras de pelito, matriz de diamictito e arenito. Cerca de $50 \mathrm{mg}$ de amostra pulverizada foi dissolvida em uma mistura ácida 3:1 de $\mathrm{HF} / \mathrm{HNO}_{3}$, concentrados, com adição de spike (concentração ${ }^{150} \mathrm{Nd}=0,510999 \mu \mathrm{g} / \mathrm{g}$ e ${ }^{149} \mathrm{Sm}=0,740918 \mu \mathrm{g} / \mathrm{g}$ ). Após secar, à amostra foram novamente adicionados $5 \mathrm{ml}$ de $\mathrm{HCl}(6 \mathrm{~N})$ e evaporado. A amostra foi então diluída em $2 \mathrm{ml}$ de $\mathrm{HNO}_{3}(1 \mathrm{~N})$ e os elementos foram separados em duas etapas. Primeiro, foram coletados os elementos terras raras em coluna de resina RE Spec, com $\mathrm{HNO}_{3} 0,05 \mathrm{~N}$. O material coletado foi seco e diluído novamente com 0,2 $\mathrm{ml}$ de $\mathrm{HCl} 0,26$ N. Na segunda etapa, os elementos $\mathrm{Nd}$ e Sm foram coletados em coluna de resina LN Spec, com HCl 0,26 N (cerca de $3 \mathrm{ml}$ desprezados e $5 \mathrm{ml}$ coletados) e 0,55 N (cerca de $2 \mathrm{ml}$ desprezados e $3 \mathrm{ml}$ coletados), respectivamente. As razões isotópicas de $\mathrm{Sm}$ e $\mathrm{Nd}$ foram medidas em espectrômetro de massa multicoletor Finnigan MAT-262. As idades $\mathrm{T}_{\mathrm{DM}}$ foram calculadas com base no modelo de DePaolo (1981). O branco analítico é de ca. 77 pg para $\mathrm{Nd}$ e de ca. 21 pg para Sm. O valor médio para a razão ${ }^{143} \mathrm{Nd} /{ }^{144} \mathrm{Nd}$ do padrão JNdi é 0,512098 \pm 0.000013 . 


\section{CAPÍTULO 3 UNIDADES LITOESTRATIGRÁFICAS}

Este capítulo apresenta as descrições sedimentológicas, correlações estratigráficas e interpretações ambientais da Formação Puga, Grupo Araras e Formação Serra Azul, que ocorrem no extremo norte da Faixa Paraguai. Estas unidades foram estudadas em perfis de campo, cortes de estrada, cavas de mineração e furos de sondagem, num total de 16 seções detalhadas. Destas, apenas as 11 de maior relevância e com controle estratigráfico estão descritas neste capítulo. As 3 seções referentes à Formação Serra Azul estão descritas em forma de artigo, no item 3.3.

\subsection{A FORMAÇÃO PUGA NO EXTREMO NORTE DA FAIXA PARAGUAI}

A Formação Puga foi descrita pela primeira vez, no morro homônimo, por Maciel (1959) na Faixa Paraguai Sul, como conglomerados de provável origem glacial. Oliveira (1964) reconheceu rochas semelhantes na Faixa Paraguai Norte e adotou para estas a mesma denominação de Maciel (1959). Posteriormente, muitos trabalhos descreveram brevemente a litologia da Formação Puga ao longo de toda a Faixa Paraguai, com a finalidade de mapeamento geológico e sem detalhamento estratigráfico ou sedimentológico, considerando o contexto glacial (Almeida, 1964; Vieira, 1965; Almeida, 1965; Figueiredo e Olivatti, 1974; Ribeiro Filho et al., 1975; Almeida, 1984; entre outros). Posteriormente, Alvarenga e Trompette (1992) realizaram o primeiro estudo detalhado da Formação Puga, em 9 seções da Faixa Paraguai Norte (em Mirassol d'Oeste e em perfil entre Bauxi e Cuiabá; Figura 2), no qual reconheceram diferentes associações de fácies da borda para o centro da bacia precursora, chegando a identificar interdigitação desta formação com o Grupo Cuiabá.

Neste trabalho, não se pretende detalhar a Formação Puga, mas apenas apresentar as fácies identificadas no extremo norte da Faixa Paraguai, ainda não abordadas em trabalhos anteriores. Para isso, foram descritos um furo de sondagem no município de Nobres e afloramentos descontínuos no mesmo município e no município de Planalto da Serra (Figura 2). As descrições das litofácies que se seguem 
obedecem a nomenclatura de Eyles et al. (1983), sendo o termo diamictito descritivo e sem conotação genética, referente a uma rocha conglomerática pobremente selecionada, composta da mistura de matriz (mais de $10 \%$ do volume da rocha) e clastos pobremente selecionados (Frakes, 1978); enquanto que os conglomerados se referem às rochas sustentadas por clastos com menos de 10\% de matriz (Eyles, 1987). As margas presentes obedecem ao sistema de classificação descritivo de Mount (1985). As litologias finas, comumente laminadas, com clastos esparsos, apresentando estruturas de sobrecargas, não receberam nomenclatura especial, sendo apenas adjetivadas com "com clastos caídos".

\subsubsection{Descrição das seções}

São apresentadas, a seguir, 3 seções colunares compostas (Figura 4), de oeste para leste, de acordo com a localização geográfica atual (Figuras 2).

\subsubsection{Seção 1: Serra da Caixa Furada, Nobres}

Esta seção possui aproximadamente 280 metros de rochas terrígenas e carbonáticas da porção intermediária e de topo da Formação Puga. Constitui um perfil de superfície, com mapeamento de afloramentos descontínuos, realizado na vertente e vale sudeste da Serra da Caixa Furada. Nestes afloramentos, foram reconhecidas fácies de diamictito suportado por matriz maciço, folhelho e marga. Últimos 100 metros desta seção compostos de intercalações de folhelhos e margas são considerados neste trabalho como pertencentes à Formação Puga, a despeito de não terem sido observados os contatos e essas litologias não terem sido descritas em trabalhos anteriores.

O diamictito maciço sustentado por matriz (Dmm) aflora extensamente no leito de estrada vicinal com domínio das colorações esverdeadas. A sua matriz argilosilto-arenosa é maciça e perfaz 70\% do arcabouço da rocha. Os clastos polimíticos são, em geral, menores que 1 centímetro, ocorrendo raros blocos, e variam de angulosos a arredondados, sendo constituídos de feldspato, granito, basalto e argilito. As camadas possuem espessuras de 40 centímetros a 1 metro. Estes pacotes de diamictito intercalam-se com camadas centimétricas subordinadas de arenito, aparentemente maciço ou apresentando estratificação incipiente irregular, e siltito laminado, compondo ciclos granodecrescentes de 1,5 a 2 metros. A ausência de 


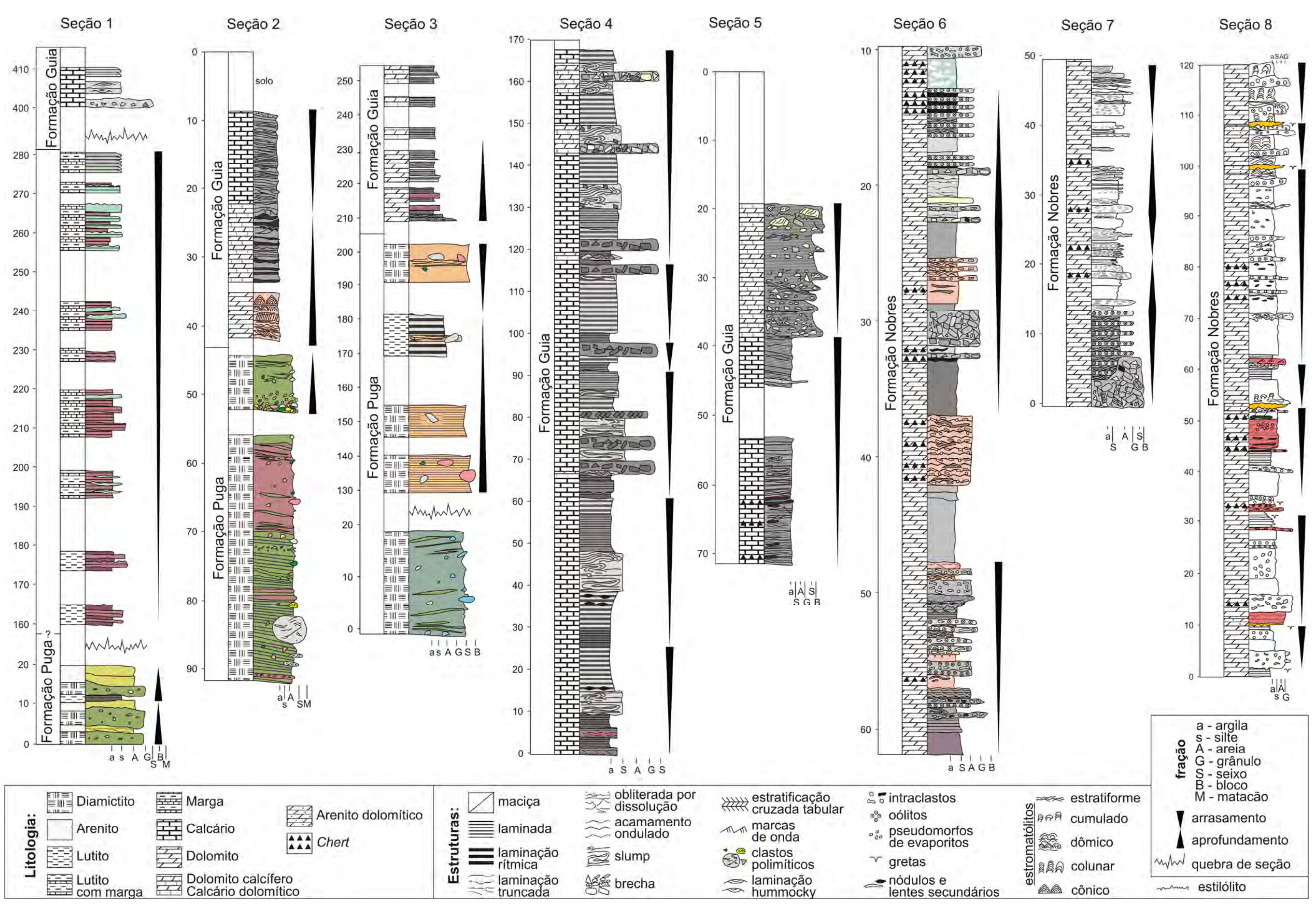

Figura 4: Representação das seções estratigráficas estudadas na Faixa Paraguai Norte. 

estratificação, domínio de matriz, baixa seleção dos clastos sugerem que esta fácies tenha sido gerada através de fluxos de detritos.

O folhelho (LI) ocorre em espessos pacotes que podem alcançar 3 metros de espessura, sendo constituídos de argilito síltico micáceo, com clivagem ardosiana e cor vermelha. Ocorrem intercalações de camadas, de até 15 centímetros, de siltito vermelho argiloso laminado, com películas brancas entre as lâminas. Também estão presentes, subordinadamente, intercalações delgadas (1 $\mathrm{mm}$ a 2 centímetros) tabulares de argilito vermelho maciço e lenticulares de marga calcífera verde maciça (Prancha 1A). A frequência das camadas de argilito diminui para o topo, enquanto que a das camadas da marga aumenta, atingindo camadas de 7 centímetros, descritas a seguir. Microscopicamente, na fração argila predominam micas e na fração silte clorita e muscovita. As películas brancas que ocorrem entre as lâminas vermelhas são constituídas de quartzo, mica e feldspato no tamanho silte. As lâminas mais espessas (1 mm), apresentam base erosiva e laminação cruzada (Prancha 1B). Ocorre grande concentração de minerais opacos, frequentemente apresentando um halo de limonita, possivelmente determinante da cor de alteração vermelha da rocha. Microscopicamente, observa-se que o folhelho apresenta um certo grau de ritmicidade com alternância de lâminas claras siltícas com gradação norma e escuras argilosas laminadas plano-paralelamente. O caráter rítmico destes folhelhos aliado a presença de lâminas siltosas com gradação normal e base erosiva sugerem uma deposição por correntes de turbidez distais, com deposição das unidades superiores da sequência de Bouma (1962).

As margas ( $\mathrm{Mm}$ e $\mathrm{Ml}$ ) são calcíferas, com composição que varia de lamito micrítico a micrito lamoso, de coloração esverdeada a avermelhada. As camadas são tabulares a lenticulares, de 4 a 20 centímetros (Prancha 1C e E). As camadas de marga estão intercaladas com folhelhos calcíferos vermelhos, que ocorrem em pacotes que variam de 3 a 20 centímetros. As margas apresentam espessamento em direção ao topo, enquanto que os folhelhos mostram adelgaçamento das camadas. A superfície basal das camadas de marga é geralmente reta e a de topo pode variar de reta a ondulada. A superfície de topo ondulada é mais comum nas camadas maciças (Mm) e de calcário impuro maciço, que ocorrem raramente (Prancha 1D). No topo da seção, na marga laminada (MI), é possível observar uma superfície irregular que trunca a laminação, coberta por uma película de (hidro?) óxido de ferro, sugestiva de 

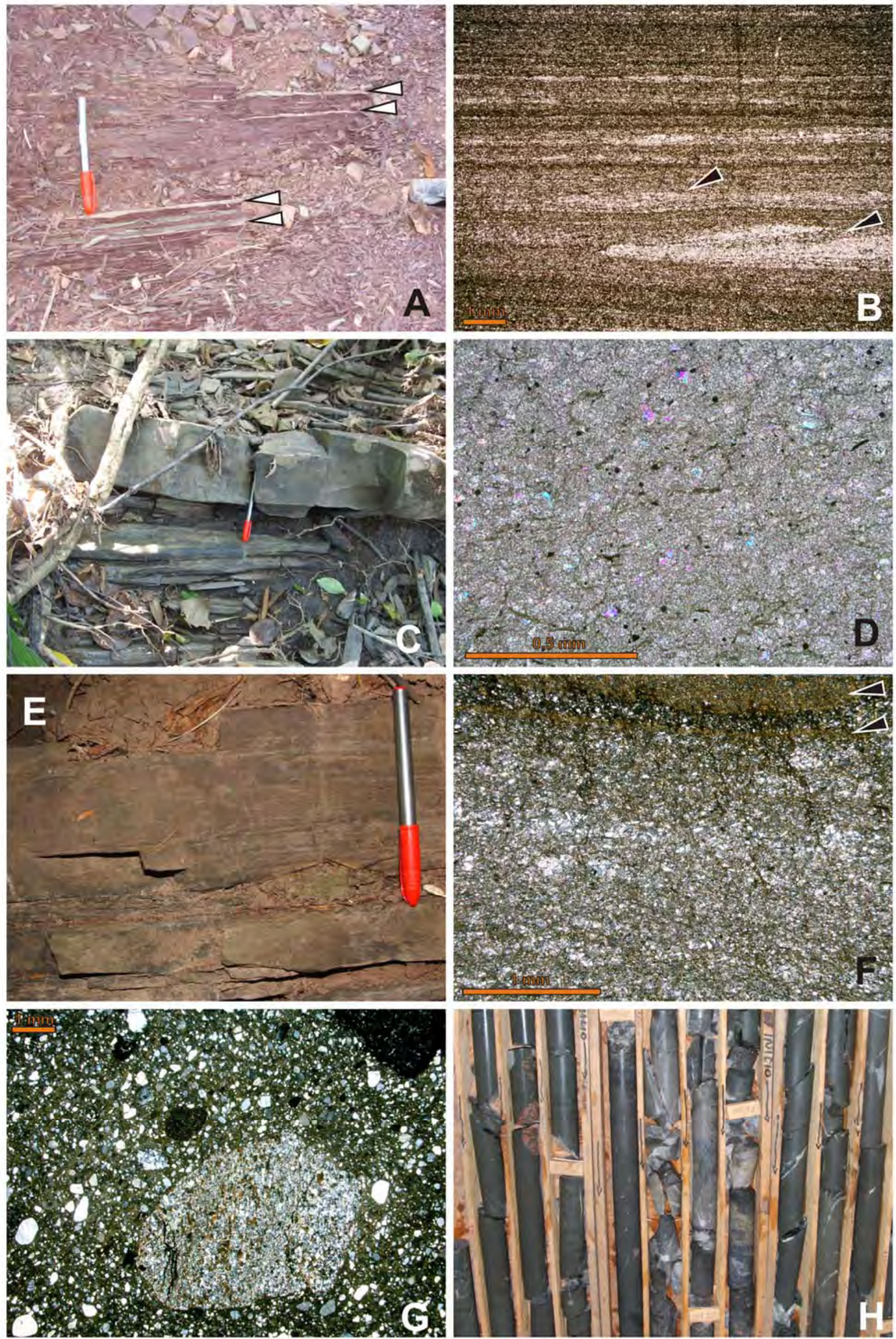
Prancha 1: Exemplares litológicos da Formação Puga. As fotografias estão orientadas com o topo para cima. Seção 1: A) Afloramento de folhelho vermelho contendo lentes de marga calcífera (setas). B) Fotomicrografia deste folhelho, cujo aspecto laminado é evidenciado pela oxidação de minerais e matéria orgânica; as lentes claras mais espessas apresentam microestratificação cruzada, com migração no sentido das setas. C) Afloramento com intercalação de camada maciça de calcário impuro dentro de marga laminada. D) Fotomicrografia deste calcário impuro, microespático e contendo muitos minerais opacos. E) Afloramento de marga laminada, com diminuição no conteúdo de argila para o topo. F) Fotomicrografia de possível hardground em marga, desenvolvido em superfície discordante da laminação e marcado pela mineralização de óxido de ferro (seta superior), com percolação nos níveis inferiores (seta inferior). Seção 2: G) Fotomicrografia de diamictito de matriz arenosa com clasto de rocha metamórfica no centro. H) Furo de sondagem molhado, com topo para cima e para direita. Da base para o topo: intervalo com diamictito maciço vermelho com clastos esparsos (esquerda), transicionando para intervalos com grandes clastos de quartzito ou camada quartzosa (centro) e, no topo, diamictito estratificado com clastos raros (notar a diferença de cores das camadas; direita). O diâmetro do furo é 2".

hardground (Prancha 1F). Nos termos menos terrígenos, observa-se geralmente laminação interna plano-paralela rítmica, com eventuais estruturas de sobrecarga. Microscopicamente, os terrígenos apresentam tamanho silte-areia fina, com grãos muito angulosos, compostos predominantemente de quartzo, sericita, clorita e biotita, e, subordinadamente, feldspato. Ocorrem raros grãos de quartzo, na fração areia média, os quais deformam a lâmina sotoposta. $\mathrm{Na}$ porção mais rítmica, as lâminas esverdeadas são constituídas predominantemente de micrita, sericita e clorita, enquanto que as lâminas esbranquiçadas de quartzo, sericita e biotita. Raramente ocorre delgada lâmina lenticular com fragmentos subesféricos no tamanho de silte, compostos de calcário micrítico. É comum a presença de minerais opacos disseminados, formando micro-aglomerados botrioidais. Estas características sugerem deposição por correntes de turbidez distais associada à precipitação carbonática em ambiente com reduzido aporte sedimentar continental, com progradação para o topo.

O contato entre os diamictitos e os folhelhos não foi observado. A transição dos folhelhos para as margas é gradativa, com aumento de calcário para o topo. O contato de topo das margas com o Grupo Araras também não foi observado.

\subsubsection{Seção 2: Furo de Sondagem, Nobres}

Esta seção é descrita no furo realizado nas proximidades do Km 580 da BR 364 (Figura 1), o qual atingiu a profundidade de 90,2 metros, dos os 45 metros basais correspondem ao topo da Formação Puga (Figura 4). As fácies reconhecidas constam 
de diamictito sustentado por matriz maciço, diamictito sustentado por matriz estratificado e diamictito maciço a gradacional sustentado por clastos.

O diamictito maciço sustentado por matriz $(\mathrm{Dmm})$ é caracterizado pelo domínio de matriz argilo-síltica-arenosa, constituindo mais de 90\% do arcabouço da rocha (Prancha 1G), com coloração avermelhada e esverdeada em alguns intervalos. Os clastos são polimíticos, predominando os clastos ígneos mais félsicos, com granulometria entre 0,05 a 8 centímetros, mal selecionados, com esfericidade e grau de arredondamento variáveis (Prancha $1 \mathrm{H}$ ). Os pacotes de diamictito maciço normalmente transicionam para diamictitos estratificados.

O diamictito estratificado sustentado por matriz (Dme) predomina ao longo do furo estudado e ocorre em intervalos métricos. A porcentagem da matriz varia entre 80 e 95\% da rocha, de coloração esverdeada a avermelhada e composição siltoarenosa a argilosa. Os clastos são esparsos na matriz, polimíticos, variando de 0,1 a 50 centímetros de comprimento, com grau de esfericidade e arredondamento bastante variados, havendo predomínio de quartzo leitoso e pirita no topo. A estratificação planoparalela é destacada pelas variações na cor da matriz e pela distribuição dos clastos, geralmente do tamanho de grânulos, ora mais concentrados ora mais dispersos. Ocorrem na forma de ciclos centimétricos com gradação normal por vezes com base erosiva (Prancha 2A). Estas características sugerem deposição por correntes de turbidez distais. Além disso, parte dos clastos ocorre rompendo verticalmente a estratificação ou a defrmando por sobrecarga, caracterizando a presença de clastos caídos e ambiente distal.

O diamictito macoiço a gradacional sustentado por clastos é representado na porção mais basal por uma camada de 2,60 metros de espessura de diamictito maciço (Dcm) sustentado por clastos, que grada para um diamictito com estratificação gradacional normal sustentado por matriz (Dmg; Prancha 2B). A matriz compõe menos de $9 \%$ da rocha, de coloração esverdeada escura e composição argilo-silto-arenosa. Os clastos são polimíticos (rochas ígneas, metamórficas e sedimentares de várias composições), sem predomínio de um tipo litológico, com tamanhos entre 0,05 a 7 centímetros, com graus de esfericidade e arredondamento variáveis. Sua ocorrência se restringe ao topo da sucessão. Esta fácies sugere uma deposição por fluxo de detritos. 
Os contatos observados entre as diferentes fácies sempre se dá de maneira gradacional, exceto para a base da fácies Dcm, que não foi observado por terem se perdido algumas caixas deste furo de sondagem.

\subsubsection{Seção 3: Fazenda Big Valley, Planalto da Serra}

Esta seção possui uma espessura aproximada de 200 metros (calculada com base nos mergulhos das camadas) de rochas da Formação Puga (Figura 2) e está localizada a 13,6 km a sul da Serra Azul, no município de Planalto da Serra (Figura 1). Para o levantamento desta seção, foram mapeados afloramentos dentro de córregos intermitentes. As fácies observadas são diamictito sustentado por matriz maciço,lutito laminado com clastos caídos e ritmito com clastos caídos.

O diamictito maciço sustentado por matriz (Dmm) localiza-se na porção mais basal, em pacote de mais de15 metros de espessura e é caracterizado por uma matriz verde, de granulometria argilo-silto-arenosa, maciça, constituindo $60 \%$ do arcabouço da rocha. Os clastos são constituídos predominantemente de carbonato (Prancha 2C), havendo também quartzito, com granulometria variando de 0,03 a 10 centímetros, com grau de esfericidade baixo e grau de arredondamento de anguloso a sub-arredondado. Os clastos maiores apresentam gradação normal para o topo, podendo se tratar de uma estratificação dentro desta fácies.

O lutito laminado com clastos caídos (LIc) é argilo-siltico com $20 \%$ de clastos caídos, de coloração de alteração alaranjada a rosada, com laminação plano-paralela a suavemente ondulada, por vezes rítmica. Os clastos são polimíticos, compostos dominantemente de quartzito, arcóseo, rocha vulcânica ácida e argilito (possível vulcânica alterada). Os tamanhos dos clastos variam de 0,05 e 60 centímetros, com predomínio de grânulos, com grau de esfericidade variável e arredondamentos de subanguloso a arredondado. Menos frequentes e mais esparsos, os clastos na fração de seixo a matacão ocorrem associados a estruturas de sobrecarga, rompendo e deformando a laminação da matriz (Prancha 2D). Sugere-se uma deposição em ambiente distal com forte influência de icebergs.

O ritmito com clastos caídos (Lrc) é observado em pacote métrico ( 3 metros), e é composto da intercalação de siltitos com argilitos, com laminação planoparalela bem desenvolvida, destacada pela alternância lâminas claras (siltito) e escuras (argilito) ricas em matéria orgânica (MO), chegando a ocorrer lâminas carbonosas 

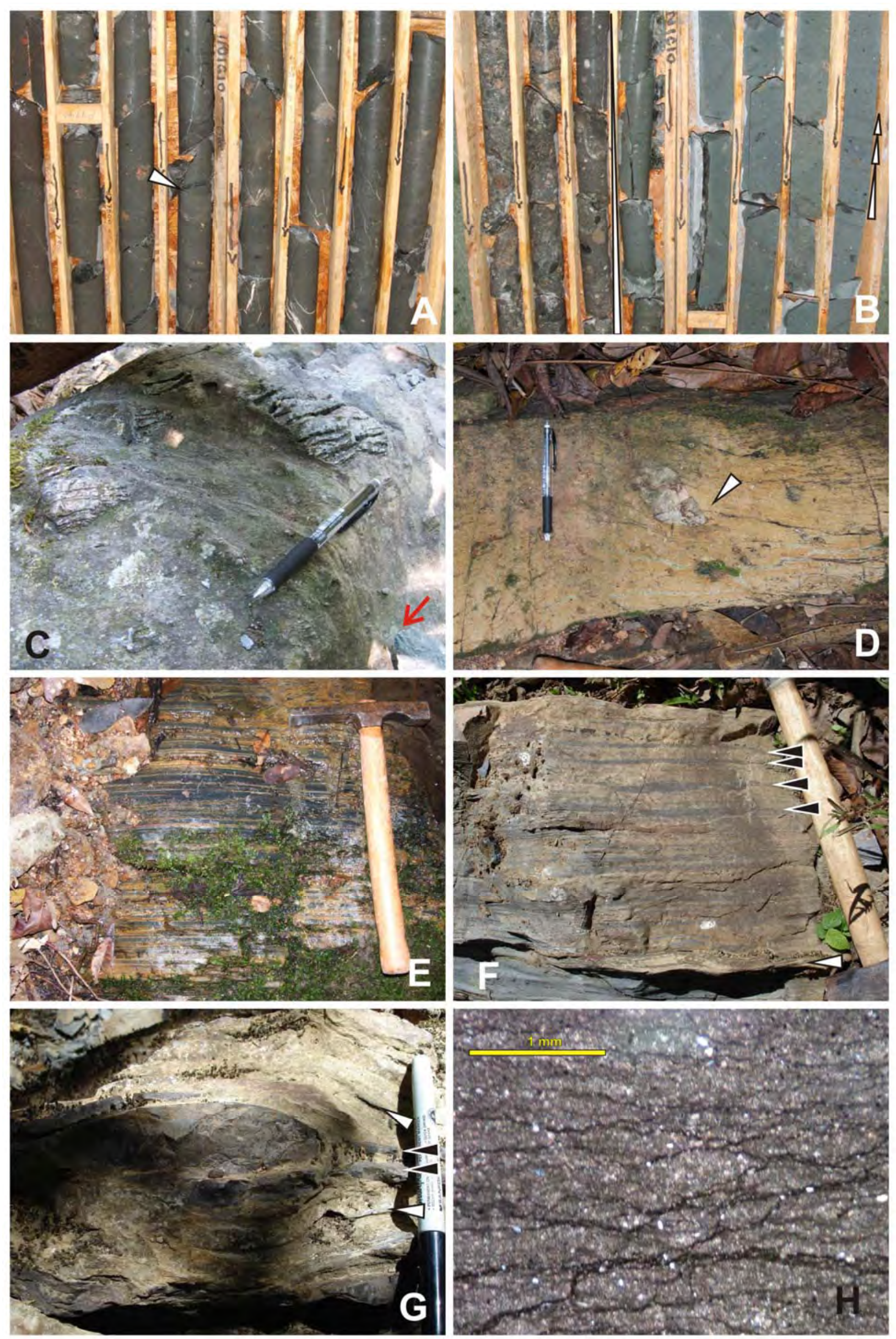
Prancha 2: Exemplares litológicos das formações Puga e Guia. As fotografias estão orientadas com o topo para cima, salvo indicação da seta vermelha. Seção 2: A) Diamictito estratificado com clastos caídos; observar superfície erosiva entre camada clara e escura (seta). B) Diamictito suportado por clastos com granodecrescência dos clastos e aumento da matriz para o topo (esquerda), seguido de diamictito estratificado com ciclos granodecrescentes (seqüência de setas à direita). Seção 3: C) Diamictito maciço com clastos carbonáticos; em raros intervalos decimétricos apresenta estratificação (lapiseira). D) Clasto caído rompendo as lâminas onduladas; observar estabilização do clasto por rotação anti-horária após a queda, levantando a lâmina de um lado (seta) e a comprimindo no lado oposto. E) ritmito alternando lâminas de siltito (claras) e argilito rico em MO (escuras); o martelo está apoiado sobre uma zona de intenso fraturamento. F) Ritmito dolomítico, observar base com laminação ondulada (seta branca) e laminação plano-paralela para o topo, com intercalações de chert negro em lâminas planas ou com base irregular (setas pretas). G) detalhe de chert negro lenticular a nodular (setas pretas), deformando lâminas adjacentes (setas brancas). H) Dolomito com textura estilonodular causado por planos de dissolução entrelaçados.

(Prancha 2E). Subordinadamente, o ritmito pode desenvolver laminação cruzada truncada por ondas, com raros clastos caídos. A deposição desta fácies é interpretada como em ambiente profundo, redutor, com chegada de correntes de turbidez distais.

\subsubsection{Ambiente Deposicional da Formação Puga}

As fácies descritas acima para a Formação Puga, no extremo norte da Faixa Paraguai, evidenciam uma deposição essencialmente subaquosa, sob influência glacial registrada principalmente pela presença de clastos caídos, predominando os processos deposicionais por fluxos gravitacionais de sedimentos e por rain out, reconhecidos como os principais processos deposicionais em sistemas marinhos glacialmente influenciados (Eyles et al., 1985).

$\mathrm{Na}$ porção mais basal da Formação Puga, que neste trabalho corresponde também à porção de águas mais profundas (Seção 3; Figura 2), a deposição se dá por fluxo de detritos proximais, gerando espessos pacotes de diamictitos maciços (Dmm), que sugerem redeposição de sedimentos provenientes de taludes íngremes. Somandose a isso, a ausência de evidências de influência glacial e a composição carbonática/arenosa dos clastos sugerem fontes plataformais, não necessariamente erodidas e transportadas por gelo.

O regime de fluxo gravitacional varia na estratigrafia, com o predomínio de deposição por correntes de turbidez (Dmm, Dme). A esse processo deposicional, comumente se associa deposição por rain out, melhor evidenciada pelos frequentes clastos caídos presentes nos turbiditos distais e lamitos laminados (Dme, Llc, Lrc). 
Eyles (1987) mostrou que fácies com alta concentração de clastos (fluxos de alta densidade) ocupam porções axiais de canais submarinos alimentados por geleiras, as quais transicionam lateralmente para fácies com gradação normal (fluxo de baixa densidade), como é o caso das fácies Dcm e Dmg. Porém, a observação restrita de apenas um furo de sondagem não permite a identificação da geometria da camada conglomerática e do seu comportamento lateral. Assim, estas fácies podem ter se originado também por fluxos de detritos em taludes íngremes.

Os turbiditos distais da fácies Dme podem ocorrer em diversos ambientes subaquosos, tais como lagos, plataforma e marinho profundo (Eyles, 1993). Durante períodos glaciais, as correntes de turbidez de baixa densidade são comuns em ambientes proglaciais, onde mudanças na descarga da água de degelo que é proveniente de geleiras induzidas por processos de marés ou variação sazonal, controlam o volume de lama transportada e depositada pelas plumas (Eyles, 1993). No caso dos diamictitos estratificados (Dme), a diminuição da espessura das camadas para o topo evidencia uma redução no volume do aporte sedimentar, que pode estar associada à transição para estações mais secas e frias.

Assumindo a presença de turbiditos marinhos ainda mais distais, Domack (1984) chega a descrever lamas glaciomarinhas laminadas, depositadas sazonalmente, semelhantes às varves. Feição semelhante a esta pode ser observada nos ritmitos da Seção 3 (Lrc). A presença de raros clastos caídos evidencia não só uma influência glacial durante a deposição destes ritmitos, mas também seu posicionamento mais distal, com a presença de um número bastante reduzido de icebergs.

Os folhelhos e margas (LI, Ml, Mm), encontrados na Seção 1, são atípicos na região, não tendo sido descritos por nenhum trabalho prévio, salvo uma breve menção de Ribeiro Filho et al. (1975) sobre a abundância de cimento carbonático no topo da Formação Puga, chegando a formar lentes de calcário que gradam para a Formação Araras (atual Grupo Araras). O caráter extremamente laminado e rítmico dos folhelhos evidencia deposição em ambiente de baixa energia, abaixo do nível de ondas, por correntes de turbidez distais. A ausência de clastos caídos registra um longo período sem deposição por rain out, provavelmente devido à interrupção na liberação de icebergs que cheguem à bacia, ao recuo pronunciado da geleira (Condon et al., 2002), ou ainda ao fim de uma glaciação. Além disso, a ocorrência de marga, cada vez mais frequente para o topo, tendendo a uma composição calcária, mostra uma diminuição do 
aporte sedimentar terrígeno, com possível diminuição da lâmina d'água e/ou aquecimento do corpo d'água. Na porção mais de topo, a ocorrência de um possível hardground pode indicar breves paradas na sedimentação, desenvolvendo crostas na superfície. A presença significativa de clorita detrítica comumente é associada às regiões de intemperismo químico reduzido, como aquelas glaciadas (Biscaye, 1965; Halam, 1984; Ruffell et al., 2002; Fürsich et al., 2005). No entanto, não foram observadas evidências glaciais ou o contato com as unidades glaciais adjacentes, 0 que dificulta uma melhor contextualização destas rochas dentro da Formação Puga.

\subsection{GRUPO ARARAS}

O Grupo Araras constitui um espesso pacote de rochas carbonáticas $(\sim 1 \mathrm{~km})$ que foram primeiramente citadas por Castelnau (1850) e denominadas de Arara limestone por Evans (1894). Posteriormente, Paes Leme (1912) identificou duas unidades composicionalmente distintas de calcários (inferior) e dolomitos (superior). A partir disto, cerca de duas dezenas de trabalhos foram realizadas nesta unidade, surgindo algumas propostas de classificação estratigráfica. A primeira delas (Almeida, 1964) estabelece o Grupo Araras, que foi dividido em Membro Guia (calcários) e Membro Nobres (dolomitos).

A partir de Figueiredo e Olivatti (1974), as rochas carbonáticas da Faixa Paraguai Norte foram reclassificadas como Formação Araras e incluídas no Grupo Alto Paraguai até que Almeida (1984) sugeriu a remoção da Formação Araras deste grupo. Nos últimos anos, Nogueira et al. (2006) propuseram retomar a classificação de Grupo Araras (Almeida, 1964), porém dividindo-o em quatro formações: Mirassol d'Oeste, Guia, Serra do Quilombo e Nobres.

Nas descrições a seguir, tenta-se posicionar as seções dentro da classificação estratigráfica de Nogueira et al. (2006), apesar desta proposta conter uma unidade de difícil identificação no campo, a Formação Serra do Quilombo. Quanto à classificação textural, foi adotada a classificação expandida e revisada de Duham (Wright, 1992) para carbonatos e uma classificação especial (Mount, 1985) para as rochas silicatocarbonáticas. 


\subsubsection{Descrição das seções}

São apresentadas a seguir 9 seções estratigráficas do Grupo Araras, da base para o topo (Figura 4). Algumas destas seções são as continuações das seções descritas anteriormente para a Formação Puga e levam o mesmo número.

\subsubsection{Seção 3: Fazenda Big Valley, Planalto da Serra}

A porção superior desta seção ( 50 metros) é essencialmente carbonática (Figura 2) e será descrita a seguir, enquanto que a porção basal foi descrita no item 3.1.1.3. com título homônimo. As rochas foram descritas em afloramentos isolados dentro de córregos intermitentes.

Nesta sucessão carbonática predomina a fácies de dololutito laminado (LI), composta por dolo-mudstone cinza escuro, com laminação plano-paralela a irregular. Ocorre subordinadamente a fácies de dololutito laminado rítmico (LIr) que alterna lâminas claras (microesparita) e escuras (micrita). Por vezes, ocorrem intercalações de chert negro em lâminas planares a lenticulares rítmicas ( 2 centímetros), frequentes na LIr (Prancha 2F), ou também em camadas nodulares que deformam as lâminas carbonáticas adjacentes da LI (Prancha 2G), sugerindo uma silicificação précompactação. As camadas de chert negro possuem bordas bem delimitadas e, internamente, guardam cristais esparsos de dolomita em textura porfirotópica. Cherts intercalados com calcários são comuns em ambientes pelágicos, desenvolvendo nódulos e camadas (Affolter, 1997), sendo a maioria formada no início da diagênese. A silicificação após a dolomitização é uma característica comum, porém a substituição da dolomita é mais lenta que da calcita, ocorrendo cristais de dolomita flutuando no chert (Whittle \& Alsharhan, 1994).

Na porção intermediária, ocorre um aumento do aporte de minerais detríticos associados à fácies LI, inicialmente como películas de argila vermelha, entre estreitas camadas de dolo-mudstone impuro com ondulação truncada, passando a uma fácies de marga laminada (LI), composta de argilito micrítico laminado.

$\mathrm{Na}$ porção mais de topo ocorrem níveis milimétricos de dolo-mudstone peloidal associado à fácies de dololutito com laminações irregulares (Lli). Microscopicamente, as laminações irregulares e truncadas são geradas por um conjunto de planos de dissolução por pressão confinadas nas camadas de composição mais calcítica. Algumas camadas chegam a desenvolver estrutura estilolaminada a estilonodular (Prancha 2H). É comum a presença de pirita disseminada e matéria 
orgânica abundante, normalmente mais concentradas nos planos de dissolução, juntamente com os minerais terrígenos, quando presentes. Estas fácies laminadas (LI, LIr, Lli) sugerem uma deposição em ambiente redutor e terreno plano, abaixo do nível de ondas de tempestade.

Na porção mais basal, pouco acima dos diamictitos da Formação Puga, ocorre doloarenito maciço com intraclastos (Ami) em camadas decimétricas, seguido de doloarenito laminado ( $\mathrm{Al}$ ), doloarenito com laminação cruzada cavalgante (Acc) e dololutito maciço (Lm). A fácies Ami é composta por dolo-floatstone cinza maciço, contendo intraclastos alongados (até 4 centímetros) de calci-mudstone cinza claro, sem orientação preferencial, em camadas de aproximadamente 20 centimetros de espessura (Prancha 3A). A fácies Acc é composta de dolo-wackestone cinza e é marcada por laminações ondulada e cruzada cavalgante crítica, em camadas centimétricas, com comprimento de onda variando de 7 a 10 centímetros (Prancha 3B). Por fim, a fácies Lm é composta de dolo-mudstone maciço, em camadas pouco espessas (até 3 centímetros; Prancha 3C). Este conjunto de fácies representa as camadas A-maciça, B-areia laminada, C-cruzada e E-lama, respectivamente, da Sequencia de Bouma (1962), cuja deposição se deu por correntes de turbidez.

\subsubsection{Seção 2: Furo de Sondagem, Nobres}

A porção superior deste furo é essencialmente carbonática e corresponde aos primeiros 35 metros do Grupo Araras, estando ausentes algumas das caixas de testemunhos que continham os 4 metros mais basais, o contato com a Formação Puga (descrita no item 3.1.1.3.) e parte dos carbonatos.

A porção mais basal é composta de dololutito laminado rítmico (LIr), com espessura aproximada de 50 centímetros, composto de dolo-mudstone cinza claro rosado, laminado e rítmico, com alternâncias de lâminas cinza claro e creme. Em alguns intervalos é possível observar um acamamento truncado. O testemunho de sondagem contém vários intervalos bastante falhados (Prancha 3D). Microscopicamente, observam-se desmicritização e redução da espessura das lâminas por vários planos de dissolução paralelos e subparalelos, que concentram minerais insolúveis, especialmente os opacos (Prancha 3E). Esta fácies é interpretada como de ambiente calmo e aparentemente oxigenado pela carência de MO, comumente abundante nas fácies da Formação Guia. 

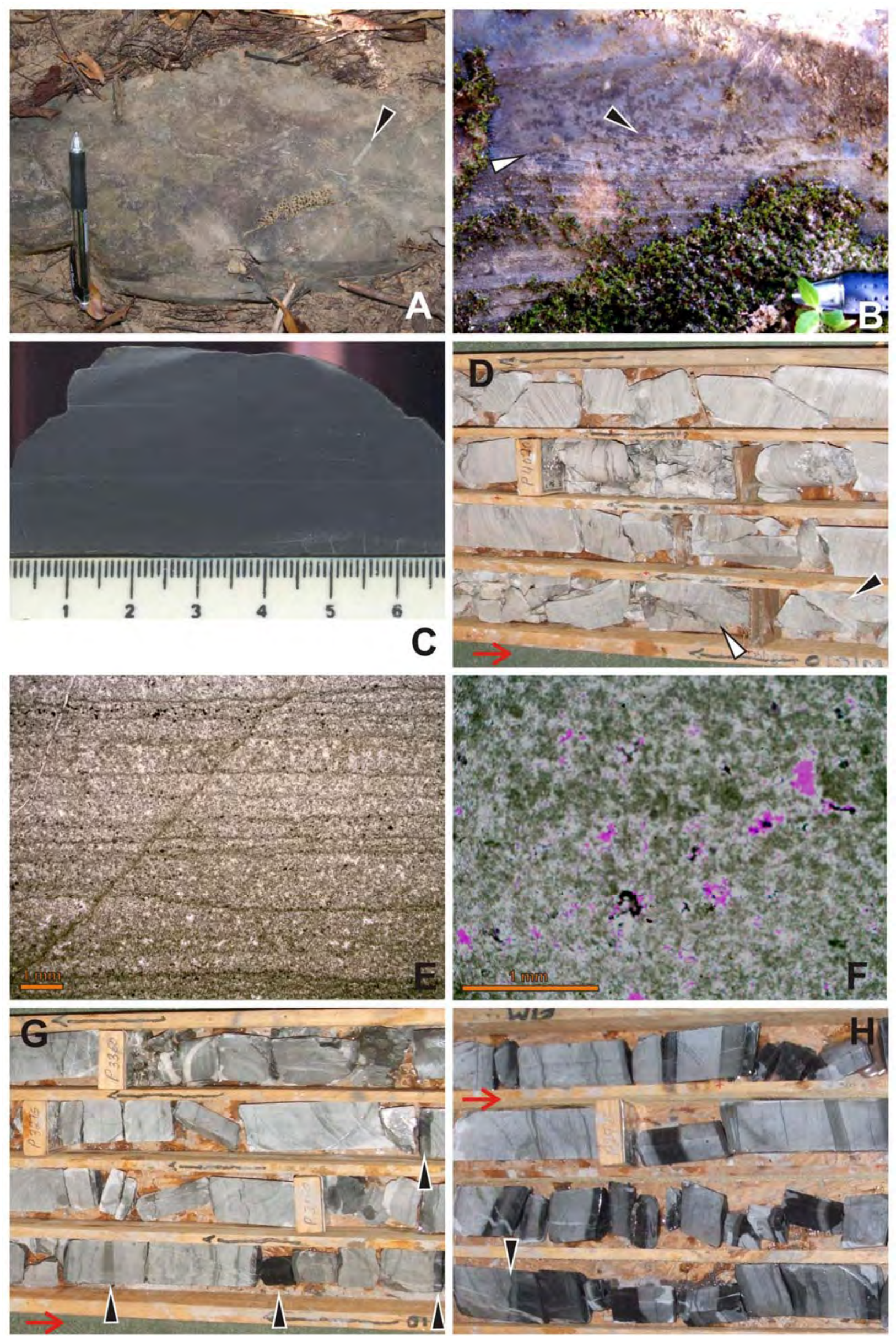
Prancha 3: Exemplares litológicos da Formação Guia. As fotografias estão orientadas com o topo para cima, salvo indicação das setas vermelhas. Seção 3: A) Dolo-floatstone com intraclastos de calci-mudstone (seta). B) Dolo-wackestone com estratificação cruzada cavalgante; as setas indicam barlavento (branca) e sotavento (preta). C) Dolo-mudstone maciço. Seção 2: D) Dolo-mudstone laminado ou rítmico, contendo estromatólitos colunares (seta branca) e cônicos (seta preta), armazenados na caixa com o topo invertido. E) Dolomudstone laminado, composto por desmicrita; as lâminas estão reduzidas por planos de dissolução subparalelos. F) Detalhe da laminação interna do estromatólito colunar em D. G) Dolo-grainstone peloidal. Calci-mudstone com espessas lâminas ricas em MO intercaladas. H) Aumento das lâminas/camadas ricas em MO para o topo; contato erosivo entre calcimudstones cinza-claro e camada rica em MO (seta).

Acima deste intervalo, segue dololutito com laminações irregulares (Lli), num intervalo de aproximadamente 3 metros, composto de dolo-mudstone laminado cinza claro rosado, apresentando ondulações simétricas truncadas e irregulares. É difícil definir a geometria destas laminações devido à escala de observação (diâmetro do furo) versus o tamanho das estruturas. Em alguns níveis, estas estruturas se assemelham à estratificação hummocky e, em outros, à laminação biogênica. Intercalam-se camadas (<10 centímetros) com a mesma litologia, apresentando diversas estruturas, como laminação incipiente (Lli), laminação com slumps (LI(s)) e brecha intraclástica $(B(i))$. No topo deste intervalo, ocorrem 20 centímetros de dololutito laminado com estromatólitos colunares conectados (Ecc) e cônicos (C; Prancha 3D). Microscopicamente, apresentam textura grumosa e peloidal (Prancha 3F). Estas fácies são interpretadas como originadas na zona fótica, no nível de atuação das ondas de tempestade, onde predominam processos deposicionais (em tempo bom) por decantação e fluxos gravitacionais em relevo inclinado.

Após intervalo de 4 metros de intervalo sem registro, inicia-se uma sucessão de 8 metros de calcilutito maciço (Lm) em camadas de 2 a 10 centímetros, composto de dolo-mudstone cinza claro, por vezes micro-espático, com intercalações de lâminas (3 milímetros) a finas camadas (4 centímetros) de matéria orgânica calcífera cada vez mais frequentes para o topo (Prancha 3G). Em algumas camadas de dolo-mudstone é possível observar fantasmas de laminação plano-paralela. O contato entre as camadas é plano ou por estilólitos que concentram MO. Nos níveis mais ricos em MO (porção de topo), ocorrem estruturas de sobrecarga e ondulações no acamamento por compactação. Na porção mais basal deste intervalo, ocorrem venulações de calcita e alta concentração de pirita.

A fácies anterior grada para uma fácies de calcilutito rítmico (LIr) rico em MO, que predomina na porção de topo do furo (16 metros). Estes ritmitos são compostos de 
calci-mudstone com laminação plano-paralela, alternando lâminas (1 milímetro a 2 centímetros) de micrita (escuras) e micro-esparita (claras). As lâminas podem se apresentar lenticulares, dobradas e deformadas (slumps), ou arqueadas e rompidas (lâminas claras). Também se intercalam camadas centimétricas de calci-mudstone micro-espático cinza claro, apresentando laminação irregular e contato erosivo. No entanto, considerando as limitações da escala de observação, estas camadas podem se tratar de níveis contendo grandes intraclastos angulosos, também observados ao longo deste intervalo rítmico (Prancha $3 \mathrm{H}$ ) e que podem corresponder à evolução de slumps para brechas intraformacionais $(\mathrm{Rm})$, fácies melhor descrita na seção 4 (item 3.2.1.4.). São comuns piritas disseminadas nas lâminas escuras ricas em MO. Ocorrem níveis micro-falhados e cortados por venulações. Esta fácies foi interpretada como uma sucessão de turbiditos distais (ritmitos) depositados em terreno inclinado, com deformação induzida por gravidade (slumps).

\subsubsection{Seção 1: Serra da Caixa Furada, Nobres}

Os carbonatos descritos aqui correspondem ao topo da seção homônima descrita no item 3.1.1.1. (Figura 4). Nesta seção, foram encontrados apenas 10 metros de calcário da Formação Guia, em um afloramento descontínuo, tendo sido reconhecidas as fácies de brecha maciça, calcilutito com hummocky, calcarenito com gradação normal e calcilutito laminado.

$\mathrm{Na}$ base encontra-se uma brecha maciça $(\mathrm{Bm})$ com 1 metro de espessura, suportada por matriz lamosa cinza clara, com clastos de até 12 centímetros de dolomudstone creme, chert cinza maciço, calci-mudstone cinza maciço e calci-mudstone laminado com nódulos de chert alinhados que lembram cristais de evaporitos (Prancha 4A). Esta fácies foi interpretada como depósito de fluxo de detritos com clastos provenientes de plataformas rasas.

$\mathrm{Na}$ porção intermediária, são encontrados calcilutitos com laminação ondulada tipo hummocky (Lh) em camadas de 20 centímetros, num intervalo de 3 metros, composto essencialmente de calci-mudstone com ondulações truncadas por onda, cujo comprimento de onda é, inicialmente, de aproximadamente 15 centímetros, passando para ondulações mais suaves com comprimento de onda de cerca de 30 centímetros (Prancha 4B). As camadas são comumen te separadas por uma fina lâmina de lama carbonática ou chert secundário, provavelmente de substituição desta 
lâmina. Estas ondulações foram consideradas como depósitos profundos de tempestade e/ou associadas ao escorregamento que formou a brecha descrita acima.

No topo, ocorre calcilutito laminado (LI), em intervalo de 1,5 metros. É composto principalmente de calci-mudstone com laminação plano-paralela, frequentemente compelículas de chert branco entre as lâminas (de 1 milímetro a 2 centimetros de espessura; Prancha 4C). Calcarenitos maciços (Am) ocorrem intercalados nesta fácies (camadas de 3 a 20 centímetros) e são compostos de calcimudstone impuro, com terrígenos na fração areia. Dentro das camadas ocorrem nódulos e camadas irregulares de chert negro secundário (até 3,5 centímetros de espessura), com preservação do carbonato no interior de alguns nódulos. Estas duas fácies intercaladas podem ter origem em correntes de turbidez, com deposição das unidades A-maciça e B-laminada de Bouma (1962). No entanto, essa interpretação é questionável, pois a laminação também pode ter sido gerada por um conjunto de planos de dissolução paralelos, expressivos no afloramento.

\subsubsection{Pedreira Copacel II, Nobres (seção 4)}

Esta seção foi estudada nas sucessivas frentes de lavras da pedreira Copacel II, próximo à cidade de Nobres, entre os anos de 2006 e 2010. Nesta pedreira encontrase, atualmente, com 170 metros de espessura de calcários da Formação Guia. As camadas assumem atitude N65E/50SE, sendo que as lentes contendo brechas e slumps assumem atitude N80E/55SE. Foram reconhecidas 4 fácies principais de calcilutito rítmico, folhelho calcítico, brecha e biostromas, com outras fácies subordinadas associadas.

Ao longo de toda a seção é possível observar pacotes métricos de calcilutito laminado rítmico (LIr). Esta fácies ocorre em camadas de 5 a 20 centímetros de dolomudstone rítmico, com alternâncias de lâminas claras (microesparita) e escuras (micrita) de espessura variável e geometria irregula. As lâminas escuras são ricas em MO e pirita, enquanto que as lâminas claras contêm terrígenos com gradação inversa em alguns intervalos (Prancha 4F). São comuns estruturas como: (a) dobras sedimentares recumbentes de pequena e média escalas (slump); (b) dobras sedimentares em chevron, quando predominam lâminas claras; (c) superfícies de truncamento intraformacional, devido à mudança do plano de acomodação conforme a cunha sedimentar é preenchida; (d) planos convexos de deslizamento, (Prancha 4D) com movimento da cunha para W-SW e sucessão de microfalhas normais ou inversas 

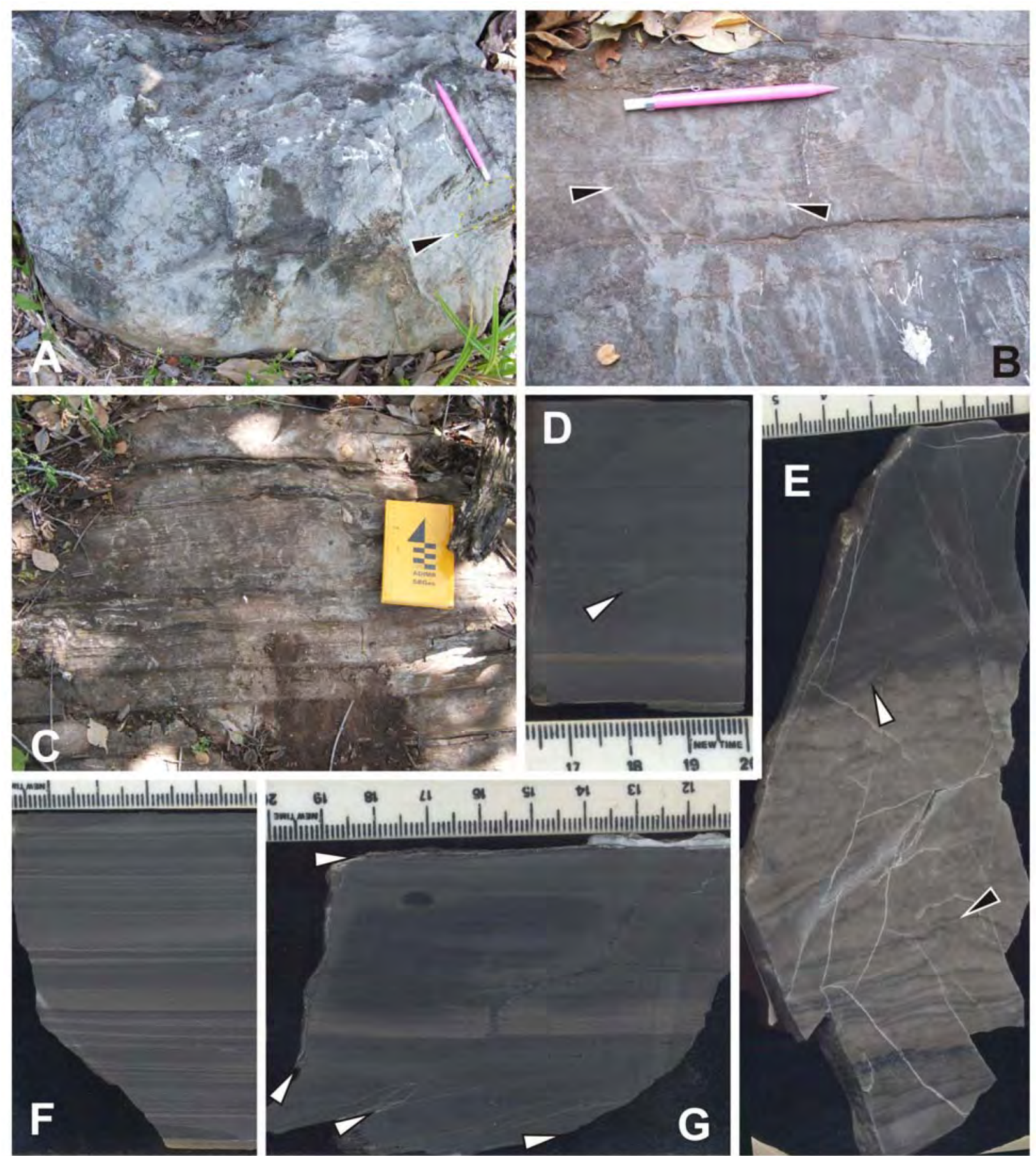

a

at $\Rightarrow$ \&

19

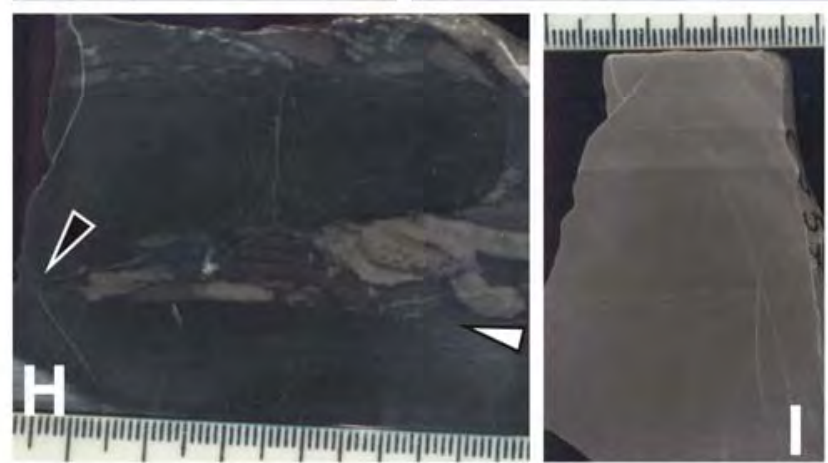

G
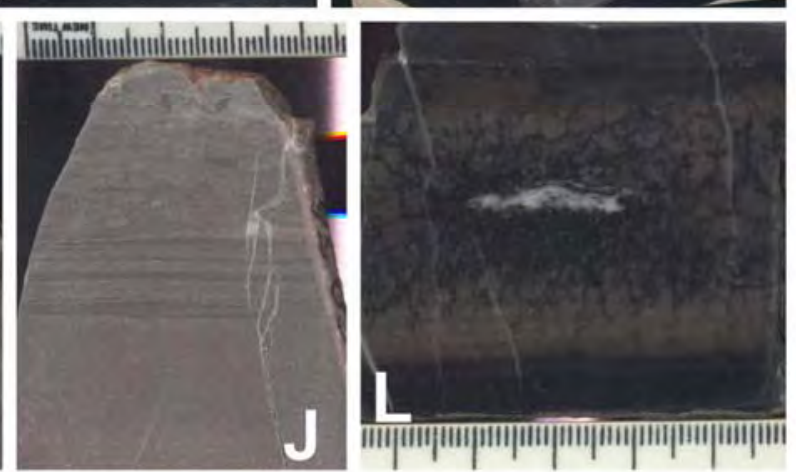
Prancha 4: Exemplares litológicos da Formação Guia. As fotografias estão orientadas com o topo para cima. Nas fotos de detalhe, as marcações menores na régua estão em milímetros. Seção 1: A) Brecha carbonática; observar clasto contendo possíveis pseudomorfos de evaporito (seta). B) Dolo-mudstone com ondulações truncadas por onda (setas). C) Calcimudstone laminado com intercalações de chert branco. Seção 4: D) Calci-mudstone laminado apresentando cavalgamento (seta). E) laminação biogênica dobrada (seta preta), seguida por calci-mudstone laminado; observar onlap (seta branca). F) Ritmito com pares claro-escuro; as lâminas mais espessas apresentam granodecrescência. G) Folhelho carbonático em zona de deslizamento intra-estratal com pequenos nódulos de chert negro; notar migração de betume pelas fraturas (setas), provocando descoloração da rocha. $\mathrm{H}$ ) detalhe do contato basal de brecha (seta branca); observar fragmento do dolo-mudstone negro sendo quebrado e descolado (seta preta). I) Calci-wackstone em lâminas ou finas camadas grano-decrescentes. J) Wackestone impuro apresentando sucessão de estruturas maciça e laminada, sobreposta por micro-brecha. L) Calci-mudstone laminado fraturado e impregnado com óleo.

associadas; (e) padrão irregular dos ritmitos, em intervalos milimétricos a decimétricos, cujas lâminas claras chegam a perder a plasticidade e rompem-se. É comum, dentro das camadas, o desenvolvimento de brechas próximo aos contatos basal e de topo, pela perda de plasticidade nas partes externas do slump, permanecendo o centro dobrado em dobras recumbentes apertadas. É possível observar intervalos com lâminas rompidas e rotacionadas, num efeito dominó, com superfície de topo aplainada e seguida por nova deposição rítmica. Nas porções mais basais da seção, ocorre a intercalação de finas camadas de calcilutito microespático (< 5 centímetros) ou intervalos de ritmitos contendo chert negro em nódulos, lentes ou camadas boudinadas por sobrecarga. Como na Seção 2, os ritmitos desta seção são interpretados como turbiditos distais que apresentam apenas as unidades superiores da Sequência de Bouma (1962). Considera-se que estes ritmitos tenham-se depositado sobre terreno inclinado devido à presença de estruturas sedimentares deformacionais causadas por distensão e compressão, devido ao deslocamento de massa por gravidade.

$\mathrm{Na}$ metade superior da seção, predominam espessos pacotes (< 20 metros) de calcilutito foliado rico em matéria orgânica (Lf (mo)), composto por mudstones negros, micríticos, finamente laminados e intercalados por filmes de MO amorfa, rica em pirita. Estes folhelhos são rítmicos e bastante quebradiços, o que dificulta sua manipulação e melhor descrição. No entanto, porções parcialmente silicificadas mostraram uma sucessão de finas lâminas margosas mais claras gradando para mudstones impuros negros, nos quais se encontram também pequenas lentes de chert negro. Esta fácies, quando contendo fraturas e zonas de cisalhamento tectônicas, apresenta as regiões próximas aos planos de fratura descoloridas, enquanto que as fraturas se encontram preenchidas por calcita e betume, demonstrando a geração de 
óleo e migração estrutural (Prancha 4G). Os filmes de MO entre as lâminas propiciam um deslizamento intra-laminar plástico, evidenciado pela presença de estrias e slikensides. Estes folhelhos ricos em MO foram considerados como depósitos de ambiente profundo, anóxico ou em zona de mínimo oxigênio, abaixo do nível de ondas de tempestade.

Brechas maciças calcárias $(\mathrm{Rm})$, por vezes com gradação normal $(\mathrm{Rg})$, são frequentes ao longo da seção, mais comuns para o topo. Ocorrem em camadas métricas lenticulares, intercaladas nos ritmitos e folhelhos. Os contatos basais normalmente se apresentam erosivos, enquanto que os de topos são transicionais para wackestones maciços, ou laminados e ondulados, compondo a unidade a da Sequência de Bouma. Também apresenta contato lateral irregular e erosivo com lentes de laminação biogênica (Llb), descritas no próximo parágrafo. A matriz é predominantemente composta de wackestone, impuro em algumas camadas (róseo; Prancha $4 \mathrm{~J}$ ), com clastos de calci-mudstones: microespático creme e cinza claro (predomina nos fragmentos maiores, até 10 centímetros), micrítico cinza e negro (variam de 1,5 milímetro a 5 centímetros) e fragmentos de ritmitos. Os clastos são predominantemente angulosos e alongados, com arestas corroídas por dissolução prédiagênese ou obliteradas por estilolitização. Em alguns casos, as brechas ocorrem descolando e rompendo finas camadas sotopostas de calci-mudstones negros (Prancha 4H). Estas brechas, quando contém apenas clastos de ritmitos e outros calcimudstones escuros, foram consideradas depósitos de fluxo de detritos resultantes da deformação progressiva por slump da fácies LIr em estado semiconsolidado. Já as brechas com predomínio de clastos mais claros, dolomíticos, são consideradas brechas mais próximas à margem de plataforma, em ambiente menos profundo.

Também ocorrem lentes de até 1 metro de espessura de calcilutito com laminação biogênica irregular (Llb), de cor creme a cinza. Estas lentes estão intercaladas em pacotes de ritmitos e folhelhos, apresentando acamamento truncado com onlap dos folhelhos sobre esta fácies, podem ocorrer em contato lateral com as brechas $(\mathrm{Rm})$. Os contatos verticais e laterais geralmente são irregulares e erosivos, comumente obliterados por estilólitos. Algumas lentes apresentam base reta e topo ondulado, com contato brusco. Internamente, as lentes de cor creme apresentam laminação irregular ou grumosa, em esteiras, podendo estar deformadas e dobradas por slump (Prancha 4E). As lentes de cor cinza apresentam estromatólitos dômicos e colunares restritos ao topo da camada, com altura de até 6 centímetros e largura de 2-5 
centímetros (base) e 1-3 centímetros (topo), conectados por esteiras. A presença destas lentes contendo laminação biogênica pode estar associada a três possibilidades. Na primeira, estas podem representar a presença de construções biogênicas em águas profundas (Coates \& Kauffman, 1973; Stanley, 1979). Na segunda, estas lentes podem constituir cunhas trazidas de posições mais rasas por deslizamento e depositadas sobre fácies pelágicas (Varnes, 1978). Na terceira, poderia ocorrer a combinação de ambas as possibilidades anteriores, com o deslizamento menos pronunciado de biohermas profundas.

Para o topo, aumenta a frequência de camadas laminadas de calcarenitos com gradação normal (Al(g)), impuros (róseos) e microespáticos (cinza; Prancha 4l). Quando em contato, por fraturamento, com os ritmitos ou folhelhos, esta fácies encontra-se impregnada de óleo (Prancha 4L). Estas camadas estão normalmente intercaladas a slumps ou brechas e são interpretadas como turbiditos distais apresentando apenas as unidades mais superiores da Sequência de Bouma.

Nas porções mais basais, ocorrem deformação e rompimento das lâminas por compactação, especialmente quando se intercalam lâminas espessas de mudstone microespático (claro), mais rígido, e mudstone impuro rico em MO (escuro), mais plástico. São observadas estruturas flame que se desenvolvem em finas lâminas de MO contorcidas dentro de lâmina mais espessa de mudstone microespático, e desenvolvimento de textura nodular nos ritmitos. As estruturas flame mostram um comportamento mais fluído dos sedimentos na deposição, enquanto que a deformação das lâminas de MO mostram também uma litificação tardia.

\subsubsection{Seção 5: Furo de sondagem, Nobres}

Este furo de sondagem está localizado nas proximidades do km 580 da BR 364 e pode ser considerado, na estratigrafia, a continuação superior da seção 2. São descritas aqui, em cerca de 50 metros de seção deste furo, 2 fácies predominantes de calcilutito rítmico e brechas com gradação normal.

Nos primeiros 30 metros ocorre calcilutito laminado rítmico (LIr), composto pela intercalação de lâminas de calci-mudstone claras (microesparita) e escuras (micrita). Na porção mais basal, é comum o aparecimento de nódulos oblatos de chert negro (<1 centímetros de espessura) associados às lâminas claras mais espessas (Prancha 5A). Também ocorrem microfalhas sedimentares, inversa e em flor positiva 

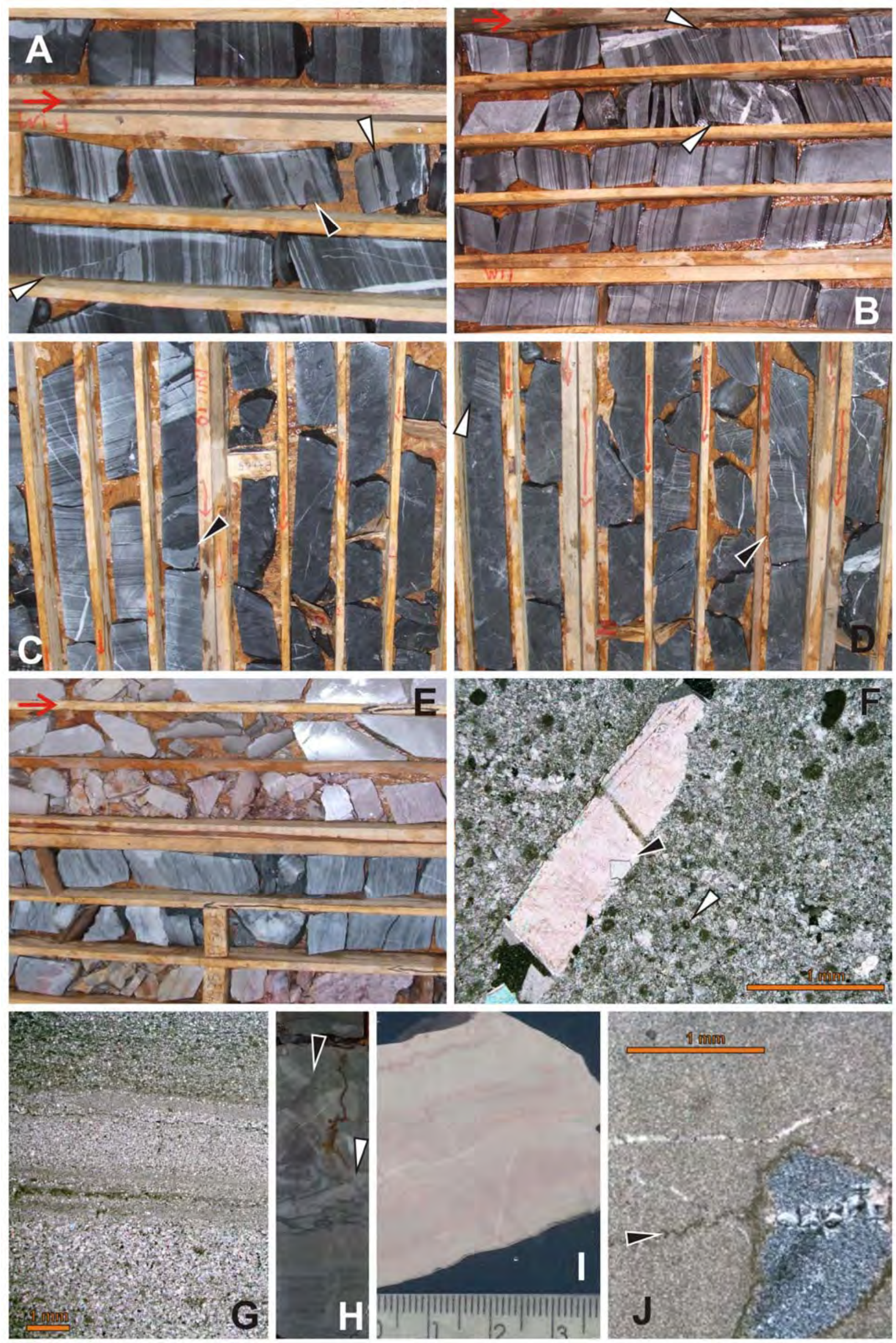
Prancha 5: Exemplares litológicos da Formação Nobres. As fotografias estão orientadas com o topo para cima. Seção 5: A) Calci-mudstone rítmico com nódulos de chert negro nas camadas claras (seta preta), estruturas em flame e microfalhas em flor positiva (setas brancas). B) Calcimudstone rítmico com dobras sin-sedimentares (lado superior). C) Calci-mudstone rítmico sobreposto por brecha dolomítica, em contato erosivo (seta). D) Brecha dolomítica; observar clasto de ritmito (seta branca), também contendo marcas de onda (seta preta). E) Da base para o topo: dolo-mudstone maciço (lado superior) seguido de textura estilonodular (fragmentos róseos), dolomudstone laminado cinza e textura estilo brechóide (lado inferior). F) Fotomicrografia de doloesparito com pellets micríticos (seta branca), com cavidades preenchidas por calcita envolvendo outros cristais (seta preta); nicóis cruzados. G) Fotomicrografia de dolo-mudstone laminado; as lâminas claras são compostas por microesparita (centro) e as escuras são desmicrita com aspecto peloidal. H) Dolo-mudstone dobrado (seta branca) com lâminas superiores rompidas formando brecha (seta preta). I) Laminação biogênica em dolo-mudstone. J) Fotomicrografia de calci-mudstone micrítico com possível nódulo de chert cortado por micro-estilólito (seta preta); planos de dissolução também envolvem o chert; nicóis cruzados.

(Prancha 5A), dobras sedimentares (Prancha 5B) restritas a níveis centimétricos a decimétricos e predomínio de estilólitos subverticais, interpretadas como evidências de pressão horizontal ao longo da camada. Algumas lâminas escuras têm o topo erodido, sobre a qual se deposita uma lâmina clara seguida do par escuro, sugerindo a ação de correntes de turbidez distais. Também se encontram micro-estruturas em flame, com reentrâncias do topo de lâminas escuras na base de lâminas claras (Prancha 5A). Para o topo deste pacote, aumentam a frequência e a espessura de delgadas camadas de calci-mudstone maciço (Lm; microespático) e inicia-se a ocorrência de delgadas camadas ( $<6$ centímetros) de calcarenito maciço (Am). O contato com as brechas de topo $(\mathrm{Rg})$ é erosivo (Prancha $5 \mathrm{C})$.

As brechas com gradação normals $(\mathrm{Rg})$ são constituídas de dolorudstone em camadas métricas com gradação normal. A matriz é composta de lama escura dolomítica, enquanto que os clastos são predominantemente de ritmitos (LIr), podendo apresentar estruturas arqueadas semelhantes às megaripples, distribuídos caoticamente na matriz, com tamanho variando de areia grossa a bloco (Prancha 5D). Estas brechas podem ser interpretadas como episódios repetidos de desestabilização de terreno inclinado, provocando fluxos de detritos.

\subsubsection{Seção 6: Furo de sondagem, Nobres}

Este furo de sondagem está localizado nas imediações do km 580 da BR 386 e possui 62 metros de profundidade, sendo os 10 primeiros metros constituídos de solo. Estratigraficamente, esta seção está posicionada acima da Seção 5 . Foram 
identificadas fácies de dololutito maciço, laminado e com laminação biogênica, calcilutito maciço, brecha, doloruditos oolítico e intraclástico, descritos abaixo. A presença de chert é marcante ao longo da seção, ocorrendo mais frequentemente como silicificação de substituição, mas também como cimento preenchendo cavidades.

$\mathrm{Na}$ porção mais basal da seção, encontra-se a fácies de dololutito maciço (Lm), composto de dolo-mudstone impuro com coloração rósea (Prancha 5E), em camada de 1,8 metros. Entre os 42-48 metros de profundidade, esta fácies assume um caráter mais puro, de cor cinza, em camadas finas. Próximo aos 25 metrosadquire coloração rósea, estando parcialmente silicificado por chert de substituição cinza azulado, em intervalos de até 6 centímetros Microscopicamente é composta de microesparita com menos de $1 \%$ de terrígenos. Alguns intervalos estão obliterados por estilólitos, desenvolvendo estrutura estilonodular e estilobrechóide, não sendo possível diferenciar clastos preexistentes (Prancha 5E).

Ocorrem, com frequência camadas de doloesparito maciço (Es) formado essencialmente por doloesparita em mosaico granular, onde a recristalização é intensa. Também são encontrados doloesparitos peloidais, com cavidades preenchidas por dolomita poiquilotópica (Prancha 5F).

A fácies de dololutito laminado (LI) ocorre em camadas de até 1 metro, sendo compostos de dolo-mudstone em lâminas cinza e cinza claro intercaladas. Estas laminações estão deformadas por compactação e planos de dissolução, em intervalos decimétricos (Prancha 5E). Microscopicamente, as lâminas claras são compostas de microesparita, com terrígenos na fração silte, enquanto que as lâminas de cor cinza são compostas de micrita rica em MO ou desmicrita com aspecto peloidal (Prancha 5G). Esta fácies apresenta slumps na porção mais basal e comumente se associa à fácies de dolorudito intraclástico e a brechas (Prancha $5 \mathrm{H}$ ).

A fácies de dololutito com laminação biogênica (Llb) ocorre em camadas inferiores a 1 metro de espessura, composta de dolo-mudstone róseo com laminação ondulada biogênica, formando esteiras e domos baixos (Prancha 5l); e por dolomudstone cinza com laminação irregular, de aspecto grumoso. Ao microscópio, as lâminas alternam micrita e microesparita, com cerca de $3 \%$ de terrígenos. No dolomudstone cinza, as lâminas microespáticas têm aspecto quase nodular por dissolução (estilonodular inicial). Estas camadas normalmente se associam ou intercalam com doloruditos pisolítico e intraclástico. 
Na porção intermediária, em um intervalo de 4 metros e outro de 50 centímetros, ocorre calcilutito maciço $(\mathrm{Lm})$ constituído de calci-mudstone cinza micrítico a microespático. Em raros níveis, ocorre o alinhamento de cherts em formatos irregulares arredondados ou alongados, cortados por estilólitos horizontais. A geometria destes cherts lembra grãos detríticos, estando seus limites também afetados por planos de dissolução. No entanto, a ocorrência restrita a níveis horizontais paralelos, estando ausentes outros minerais ou fragmentos terrígenos com dimensões semelhantes, sugere uma silicificação secundária anterior à compactação, ou de substituição seletiva, ou de preenchimento de cavidades (Prancha 5J).

Os doloruditos pisolítico $(\mathrm{Rm}(\mathrm{ps})$ ) e intraclástico $(\mathrm{Rm}(\mathrm{i})$ ) ocorrem em camadas centimétricas a decimétricas, intercalados com finas camadas de LI, Lm e Llb. A fácies $\mathrm{Rm}(\mathrm{ps})$ é composta por grainstones pisolíticos, contendo intraclastos (Prancha $6 \mathrm{~A}$ ), cimentado por dolomita dente de cão e granular, em mosaico drusóide, preenchendo completa ou parcialmente os espaços intergranulares. Em intervalos onde ocorre desmicritização, a porosidade intergranular primária é parcialmente preservada (Prancha 6B). A fácies Rm(i) é composta de packstones intraclásticos, podendo conter oólitos e pisólitos, com matriz constituída de microesparita impura a arenito fino calcífero. O cimento é composto por doloesparita granular. Os clastos são alongados e esféricos, os quais variam de 0,2 a 4 milímetros. Em alguns intervalos é possível observar gradação normal em ciclos centimétricos, com base erosiva (Prancha 6C). Ambos pisólitos e intraclastos estão comumente micritizados (Prancha 6D).

Brechas maciças $(\mathrm{Rm})$ ocorrem em camadas métricas e são compostas de intraclastos angulosos, alongados ou esféricos, de calci e dolo-mudstones de cor cinza, creme e rosa. Os clastos variam de 0,1 a 5 centímetros. A matriz é composta de dololutito e representa menos de $5 \%$ da fácies.

\subsubsection{Seção 7: Pedreira Copacel I, Nobres}

Esta seção foi estudada na frente de lavra da pedreira Copacel I, na zona sul da cidade de Nobres e possui 70 metros de espessura. As camadas encontram-se próximas ao eixo de uma dobra regional e assumem atitude N45W/10NE, cortadas por uma falha normal de baixo ângulo com atitudes do plano N10E/20NW e das estrias N40W/12. Trata-se de uma sucessão granular composta de dolomitos, cujas fácies identificadas foram: doloruditos maciços oncolítico e intraclástico, brecha maciça, 

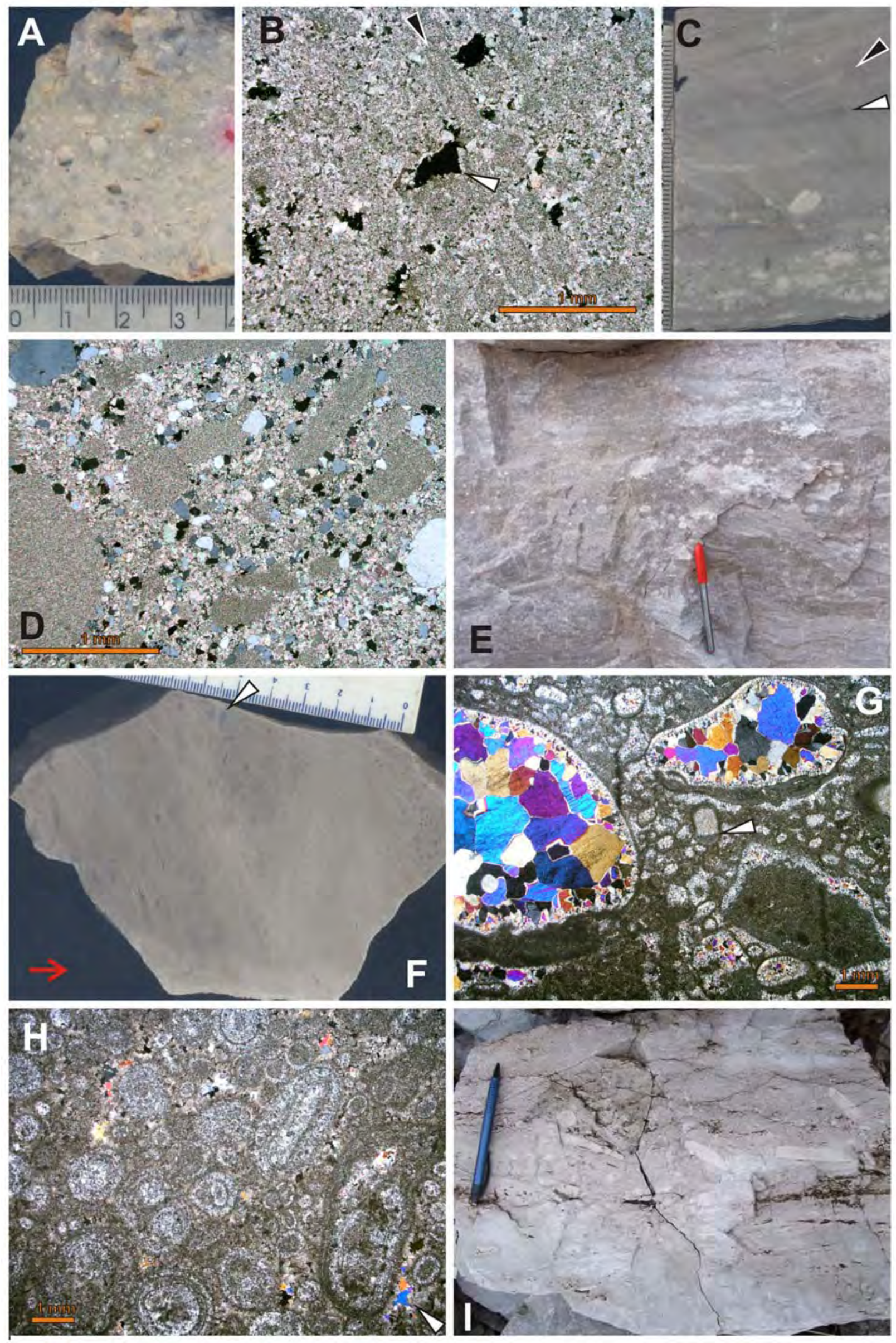
Prancha 6: Exemplares litológicos da Formação Nobres. As fotografias estão orientadas com o topo para cima, salvo quando indicado pela seta vermelha. Seção 6: A) Grainstone pisolítico com intraclastos. B) Fotomicrografia de grainstone com oólitos, pisólitos e intraclastos compostos por desmicrita (seta preta), guardando parte da porosidade intergranular primária (seta branca). C) Grainstone intraclástico impuro em ciclos granodecrescentes; observar variação no ângulo do plano de deposição (setas). D) Fotomicrografia de grainstone impuro com grãos carbonáticos micritizados; nicóis cruzados. Seção 7: E) Dolo-rudstone oncolítico, parcialmente silicificado; as porções alteradas (brancas) evidenciam os grãos e os aglomerados de oncólitos. F) Dolorudstone apresentando silicificação seletiva dos grãos (pontos de tonalidade mais escura) e de preenchimento dos poros (seta). G) Fotomicrografia de dolo-rudstone silicificado seletivamente; os grãos maiores apresentam a base coberta com micrita, interpretados como dripstone; a micrita também ocorre preenchendo a base dos poros gerados pela dissolução dos grãos (seta), posteriormente preenchidos por microesparita e esparita drusóide; esta esparita foi parcialmente ou completamente substituída por sílica; nicóis cruzados. H) Fotomicrografia de grainstone com grãos preservados e silicificação de preenchimento dos poros intergranulares (seta); nicóis cruzados. I) Dolo-rudstone granodecrescente com clastos de dolo-mudstone róseo.

doloarenitos peloidal e com estratificação cruzada tabular ou festonada, dololutito maciço, dololutido com laminação biogênica e chert. Predominam as fácies de doloruditos, doloarenitos e dololutito com laminação biogênica.

A fácies de dolorudito oncolítico maciço ( $\mathrm{Rm}$ (on)) ocorre em camadas decimétricas de até 1 metro. É composta por dolorudstone com grãos (silicáticos, carbonáticos) na fração areia, oncólitos de até 3 centímetros de diâmetro e intraclastos/oólitos (Prancha 6E). Os intraclastos e os oólitos frequentemente servem de núcleo para o crescimento de micro esteiras no seu entorno, caracterizando floatstones. Ocorrem também agrupamentos de oncólitos, gerando oncólitos maiores com vários núcleos. Oncólitos, oólitos e intraclastos encontram-se comumente silicificados seletivamente (Prancha 6F), envoltos por cimento dolomítico bladed ou dente de cão circungranulares. Nas porções mais basais da seção, esta fácies apresenta uma completa substituição dos grãos maiores por megaquartzo, permanecendo preservado seu contorno pela não dissolução do cimento micrítico isópaco e dripstone gravitacional (Prancha 6G). A evolução diagenética interpretada para esta fácies inicia-se com a dissolução dos grãos, seguida da precipitação de cimento fibroso que contorna as paredes dos poros intragranulares, posteriormente preenchidos por completo com cimento em mosaico drusóide, finalmente substituídos seletivamente por sílica (Prancha 6G). Em outras amostras que não sofreram dissolução dos grãos, os poros remanescentes foram também preenchidos por sílica (Prancha 6F e H). Esta fácies evolui para a fácies de esteiras algáceas e, sequencialmente, de estromatólitos. 

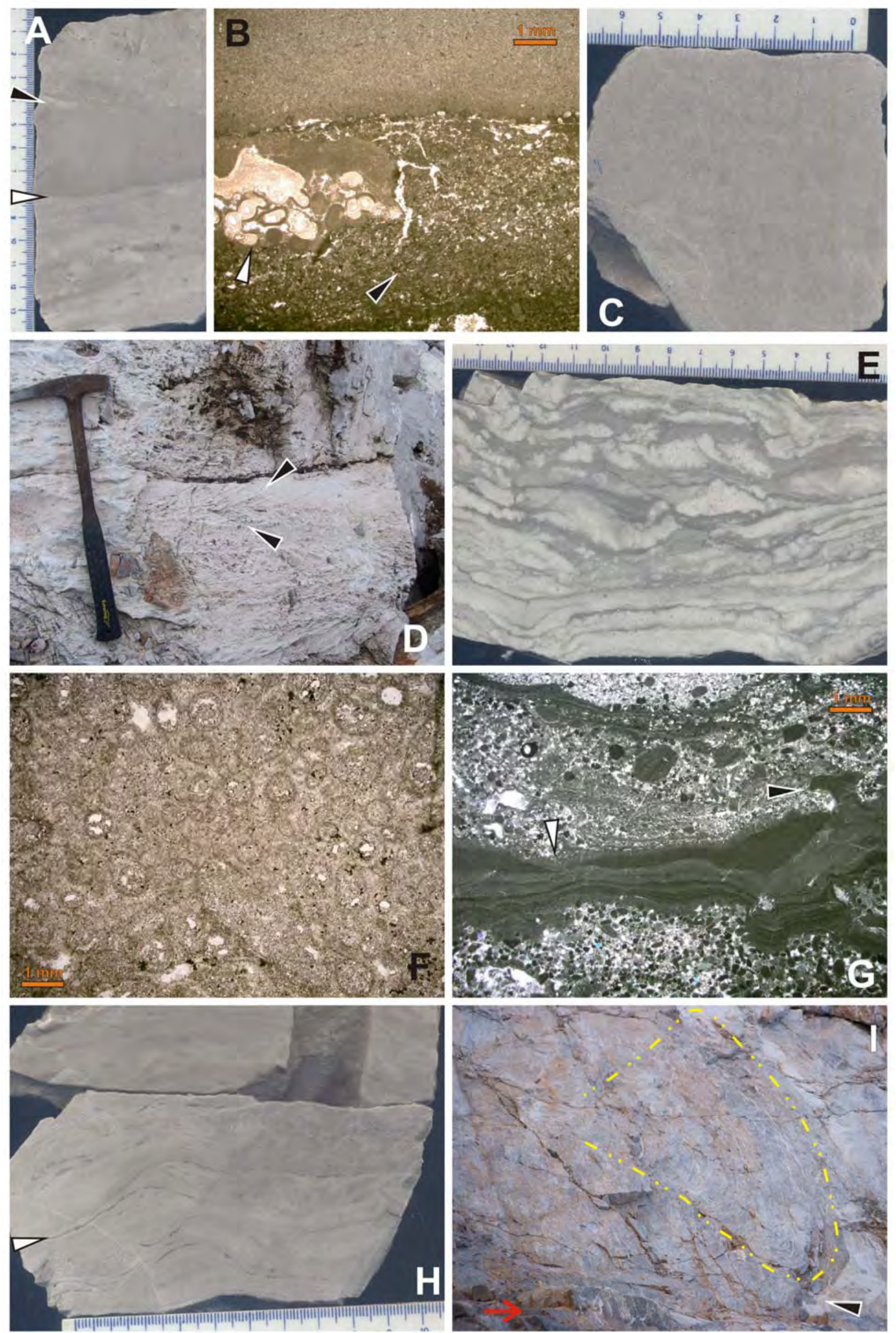
Prancha 7: Exemplares da Formação Nobres. As fotografias estão orientadas com o topo para cima, salvo quando indicado pela seta vermelha. Seção 7: A) Dolo-rudstone granodecrescente intercalado com dolomudstone; contato basal do dolo-rudstone é erosivo (seta preta), enquanto que contato de topo com dolomudstone é brusco (seta branca). B) Fotomicrografia do contato entre topo do dolorudstone granodecrescente e dolomudstone; o dolo-rudstone tem matriz oolítica, com porção silicificada (seta branca) que provoca a deformação dos oólitos à sua volta, em forma elipsóide (seta preta). C) Dolo-grainstone oolítico maciço. D) Dolo-grainstone oolítico com laminação cruzada tipo espinha de peixe; as setas indicam sentidos contrários de migração. E) Acamamento tipo flaser (base) e wavy (topo) de grainstone oolítico (claro) e esteiras algais (escuro) alternados. F) Fotomicrografia de grainstone oolítico recristalizado, com porosidade secundária intragranular. G) Laminação biogênica aprisionando oólitos e intercalando dolo-grainstone oolítico com fragmentos de esteiras; as esteiras apresentam estruturas em chama (seta preta) e adelgaçamento das lâminas (seta branca). H) detalhe da laminação interna de estromatólito com ondulação evidenciada principalmente por lâminas de chert (seta branca). I) Estromatólito colunar bulboso (contorno tracejado amarelo) de $40 \mathrm{~cm}$ de altura, com topo coberto por camada silicosa (seta preta).

A fácies de dolorudito intraclástico apresenta estrutura com clastos desorganizados (Rm (i)) ou com clastos imbricados ( $\mathrm{Rm}$ (im)). Ocorre em camadas finas entre esteiras algais, calcarenitos oolíticos e dololutitos. É composta de dolograinstone róseo com gradação normal, com matriz oolítica/peloidal e clastos alongados variando de 2 milímetros a 1,7 centímetros, nas camadas centimétricas com menos de $20 \%$ de matriz, e de 2 milímetros a 8 centímetros, nas camadas decimétricas com mais de $30 \%$ de matriz. Os clastos apresentam baixa esfericidade e arestas arredondadas (Prancha 6I e Prancha 7A). Quando imbricados, os clastos apresentam uma atitude N40W/30SW. O contato basal destas camadas é erosivo, enquanto que o de topo é gradacional ou brusco (Prancha 7A e B). Na porção mais basal desta seção, observa-se o desenvolvimento de cavidades e dutos por dissolução nas camadas com maior porcentagem de matriz, ocorrendo o preenchimento por grainstones oolíticos/intraclásticos e precipitação de calcedônia geopetal, também como substituição parcial da matriz e como cimento (comparar com a fácies Rm (es)).

Para o topo, aumenta a freqüência de doloarenitos oolíticos maciço e com laminação cruzada tabular (Am(0o) e At(0o)) em finas camadas. Estas fácies são compostas de dolograinstone oolítico cinza claro, na fração areia média a grossa (Prancha 7C), podendo conter intraclastos e pisólitos esporádicos. A fácies At apresenta laminação cruzada com sentidos opostos, formando feição espinha de peixe nos intervalos com empilhamento de sets (Prancha 7D). Nas camadas heterolíticas com alternância de dolograinstone e dolo-mudstone ou esteiras algais, formam-se acamamentos heterolíticos flaser, wavy e lenticular, (Prancha 7E). Esta fácies também ocorre como finas camadas sobrepondo de modo erosivo camadas de dolorudito 
intraclástico. A fáceis $\mathrm{Am}(\mathrm{Oo})$ encontra-se comumente recristalizada, com os contornos dos oólitos preservados (Prancha 7F).

As laminações algais, comuns ao longo de toda a sucessão, são descritas aqui como dolotutito com laminação biogênica (LIb). Esta fácies é composta de dolomudstone cinza claro ou róseo, com laminação irregular, ondulada e/ou truncada, frequentemente aprisionando intraclastos ou oólitos (Prancha 7G). A laminação é evidenciada principalmente pela alternância de lâminas claras (microespáticas ou espáticas) e escuras (micríticas), ou intercalação de filmes/lâminas de quartzo após esparita entre as lâminas carbonáticas (Prancha $7 \mathrm{H}$ ). Estas laminações ocorrem tanto como biostromas, quanto biohermas. As biostromas apresentam geometrias tabular e dômica, com aspecto ondulatório e pseudo-colunar. As biohermas apresentam geometria tabular, com estromatólitos colunares bulbosos contendo laminação interna ondulada (Prancha $7 \mathrm{H}$ ), diâmetro basal de aproximadamente 8 centímetros e maior diâmetro de topo de $\leq 40$ centímetros e altura entre 30 a 40 centímetros (Prancha 7l). As biostromas ocorrem frequentemente como boundstones, com a intercalação de esteiras e lentes de intraclastos/oólitos (Prancha 7E), enquanto que as biohermas compõem framestones.

Na primeira metade da seção, predomina a fácies de brecha maciça $(\mathrm{Bm})$, com espessura das camadas menor que 1 metro. São compostas de dolo-rudstone cimentado por esparita dente de cachorro circungranular e granular em mosaico, com posterior silicificação parcial através da substituição do cimento, com a precipitação de sílica fibrosa radial envolta de silicatos (Prancha 8A). Os clastos são compostos de dolo-rudstone intraclástico, doloarenito oolítico parcialmente silicificado (Prancha 8B), dolo-mudstone com laminação biogênica, fragmentos de nódulos de chert isolados ou dentro de clastos carbonáticos (Prancha $8 \mathrm{C}$ ) e grãos arredondados de quartzo. Os clastos variam de 1 milímetros a 50 centímetros, com esfericidade e arredondamento variável. O arcabouço original foi obliterado pela dissolução por pressão (na compactação), com revestimento carbonático e ferroso dos clastos (Prancha 8D). Os contatos entre os clastos são, predominantemente, côncavo-convexos, planares e, menos frequentemente, pontuais. Os clastos de carbonato contendo chert são muito semelhantes àqueles encontrados ao longo da seção e sugerem uma silicificação que antecede a deposição destas brechas. Cherts são formados em diversos ambientes, 
especialmente nos hipersalinos e em superfícies de exposição subaérea (Knauth, 1979), ou em zonas de mistura na plataforma (Laschet, 1984).

Com menor frequência, ocorrem camadas de doloesparito (Es), com até 2 metros de espessura, compostode doloesparito de cor cinza clara, de aspecto maciço, com frequentes microdrusas. Microscopicamente, os cristais de esparita chegam a 0,2 milímetros nos dolomitos parcialmente silicificados e a 0,4 milímetros nos dolomitos puros. A silicificação presente ocorre substituindo completo ou parcialmente o cimento intergranular, em mosaico, com o aumento do tamanho dos cristais para o centro dos poros (Prancha 8E) ou como franjas com pelo menos 5 gerações de cimento (Prancha 8F e G). Esta silicificação do cimento associada à desmicritização dos grãos guardaram, em algumas camadas, sombras de oólitos e intraclastos, medindo até 4 milímetros. Nas camadas não silicificadas, são observados grãos esporádicos, arredondados e alongados, de até 0,6 milímetros de comprimento, micritizados, com cimento isópaco circungranular, imersos em cimento de textura granular (Prancha $8 \mathrm{H})$.

\subsubsection{Seção 8: Pedreira Mato Grosso, Nobres}

Esta seção possui 120 metros de espessura e compõe o topo da Formação Nobres, tendo sido estudada na frente de lavra da pedreira Mato Grosso, situada a 4 km N-NE da cidade de Nobres. As camadas assumem atitude N60E/40SE, ocorrendo uma falha reversa N30E/45SE com 3,20 metros de rejeito. Possui uma grande variedade de fácies, predominando doloruditos com gradação normals, arenitos dolomíticos, acamamento heterolítico gretado ou com laminação biogênica.

Nas porções mais basais da seção, é comum a presença de doloarenito com laminação incipiente contendo evaporitos $(A(e v))$ em camadas métricas. É composto de dolo-packstone impuro a arenito médio dolomítico, contendo cristais de quartzo após anidrita (pseudomorfo) em nódulos esparsos ou condensados (chicken wire), lentes e finas camadas. As camadas encontram-se suavemente contorcidas (Prancha 9A), enquanto que as lentes e nódulos estão associados a intervalos menos frequentes com pequenas lamelas de sílex após gipsita ( $<1$ centímetros de comprimento; Prancha 9B) ou quartzo após halita (<5 milímetros). Esta fácies ocorre acima de dolomitos maciços com porosidade secundária e preenchimento de cavidades por chert. A presença destes pseudomorfos de minerais evaporíticos foi interpretada como indicadora de condições áridas e ambiente litorâneo com exposições prolongadas. 

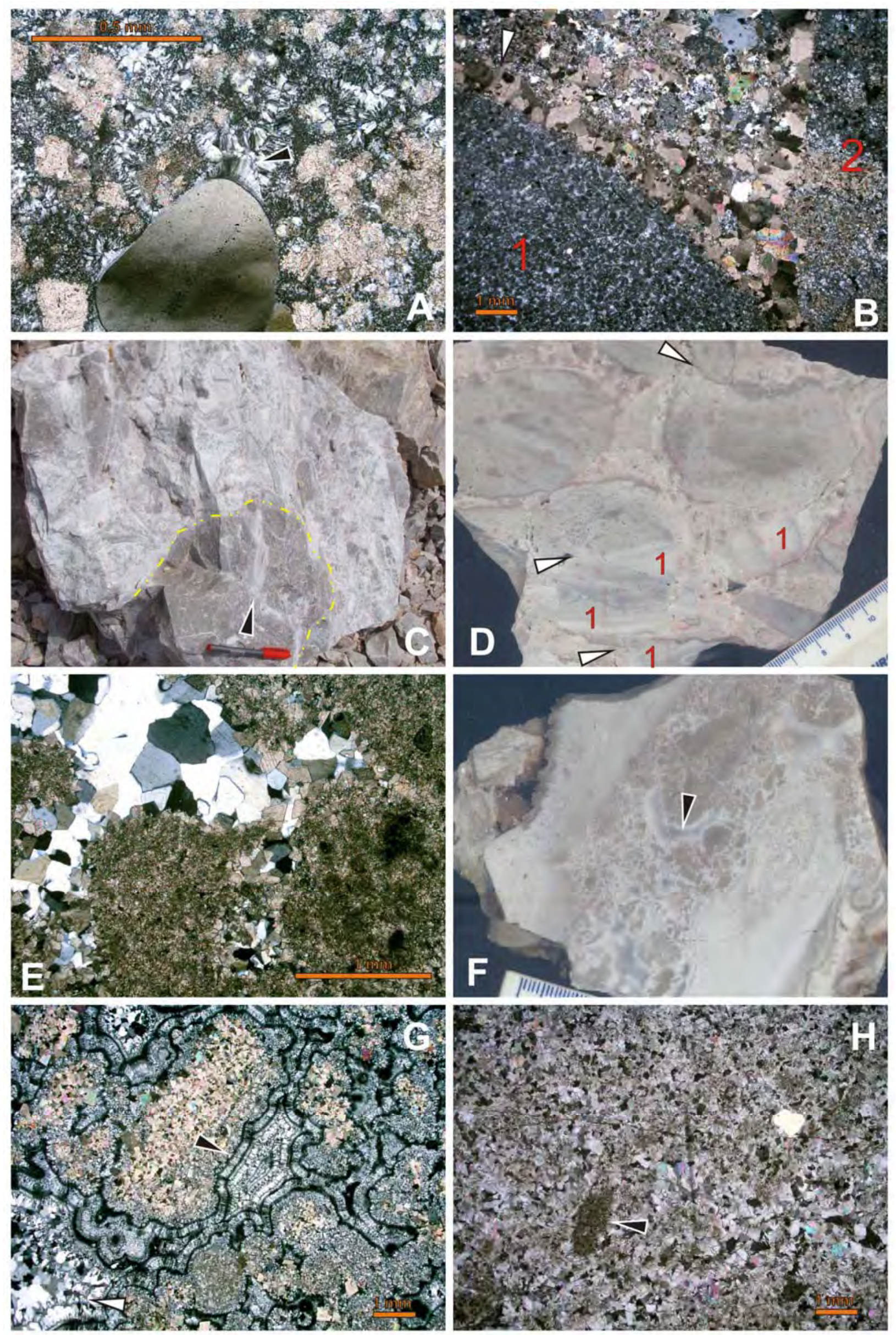
Prancha 8: Exemplares litológicos da Formação Nobres. As fotografias estão orientadas com o topo para cima, salvo quando indicado pela seta vermelha. Seção 7: A) Fotomicrografia da matriz de brecha maciça, mostrando sílica fibrosa radial como cimento, em especial envolta do grão de quartzo (seta); nicóis cruzados. B) Fotomicrografia da mesma brecha, mostrando clastos de grainstones oolíticos parcialmente silicificados (1) e cimentados por esparita granular (2). C) Brecha com clasto maior contendo nódulo de chert (seta preta); topo não definido. D) Detalhe de brecha com clastos de grainstone oolítico parcialmente silicificado, com lâminas de chert (1); apresenta contato côncavo-convexo, planar e pontual entre os clastos (setas). E) Fotomicrografia de doloesparito apresentando sombra de grãos desmicritizados, com poros preenchidos por sílica; nicóis cruzados. F) Doloesparito com poros secundários preenchidos por calcedônia (seta). G) Fotomicrografia do doloesparito em F, mostrando ao menos 5 gerações de cimento fibroso (seta preta) e preenchimento de cavidades remanescentes por megaquartzo (seta branca); nicóis cruzados. H) Fotomicrografia de doloesparito com possíveis grãos micritizados (seta); nicóis cruzados.

A fácies heterolítica $(\mathrm{H})$ ocorre em camadas decimétricas, na primeira metade da seção, e é composta da intercalação de lâminas espessas de dolo-mudstone impuro cinza escuro, rico em MO, e arenito fino dolomítico cinza (cor de alteração: amarelo). As lâminas de dolo-mudstone apresentam alta concentração de $\mathrm{MO}$ e pirita disseminada e estão geralmente gretadas. Aglomerados de pirita chegam a medir 0,4 milímetros nos intervalos com presença de microesteiras algais revestindo as gretas. Também se observam pseudomorfos de sílica, que se assemelham a cristais de anidrita, revestindo ou preenchendo algumas gretas, de forma que a geometria parece alargada (preservada na compactação; Prancha 9C). Em alguns intervalos, estas lâminas de dolo-mudstones apresentam-se como intraclastos subparalelos ao acamamento ou inclinados, como resultado de um intenso ressecamento e curto deslocamento. A fração arenosa ocorre preenchendo as gretas e/ou intercalando as lâminas de dolo-mudstones, podendo estar rompidas pela evolução das gretas subjacentes para os níveis superiores. Apresentam frequentes marcas de ondas na superfície, simétricas, com crista reta bifurcada e subparalela (Prancha 9D), com direção da crista N45E, N55E e N75E. Em alguns níveis apresenta ondas de interferência. As laminações cruzadas associadas mostram dois sentidos de corrente contrários, que mergulham ora para N30W, ora para S35E. Também ocorrem lâminas arenosas maciças tabulares, com pingos de chuva assimétricos na superfície, com diâmetro máximo de 0,4 centímetros (Prancha 9E). Esta fácies foi considerada o produto de inundações e exposições periódicas, em ambiente hipersalino, com intenso gretamento e precipitação de evaporitos na fração mais porosa devido ao clima árido ou semi-árido. A predominância de evaporitos nas porções mais profundas das gretas 

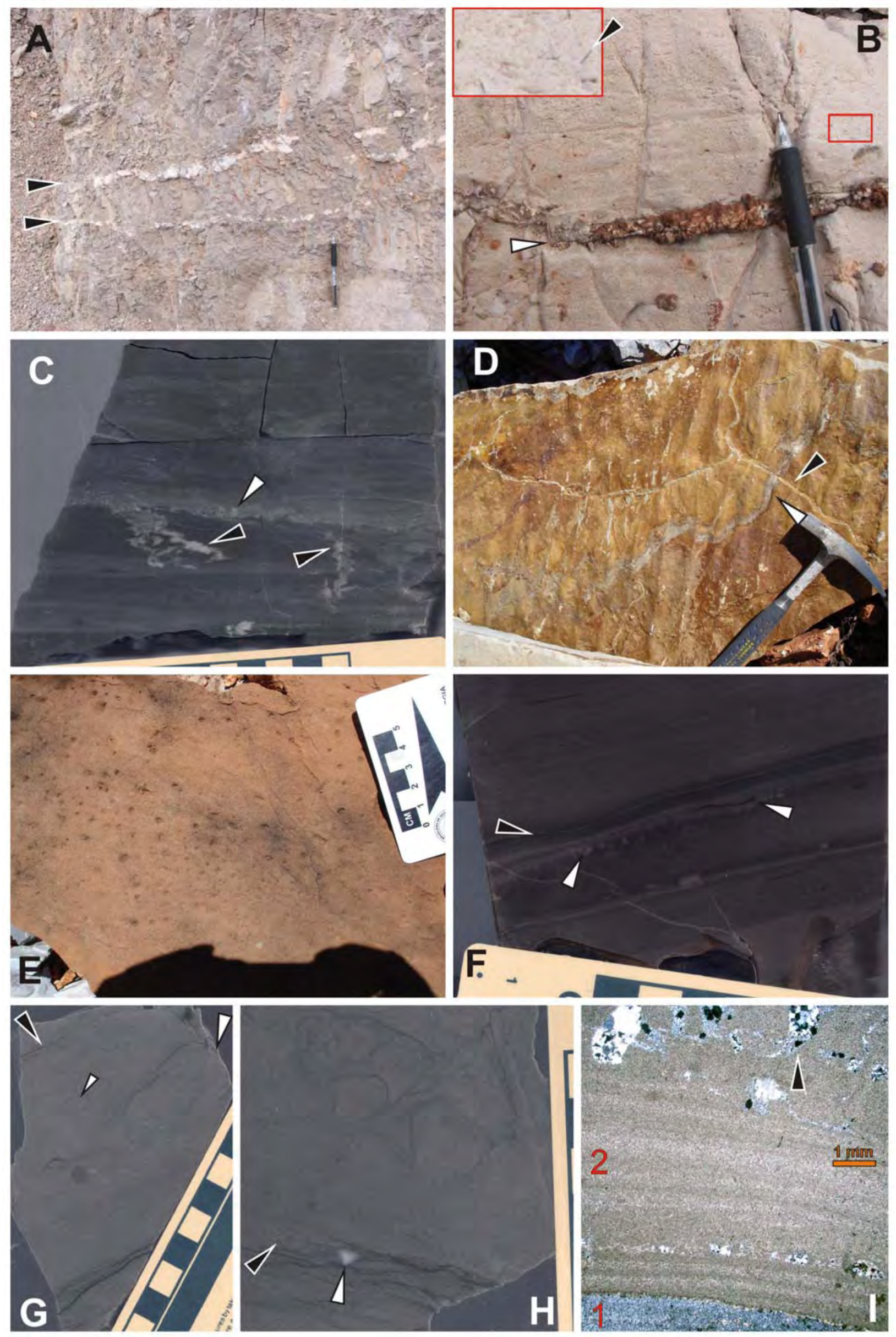
Prancha 9: Exemplares litológicos da Formação Nobres. As fotografias em corte estão orientadas com o topo para cima. Seção 8: A) Camadas de quartzo contorcidas (setas), interpretadas como pseudomorfos de evaporitos. B) Lente de nódulos de evaporitos silicificados (seta branca), com detalhe (quadro vermelho) de lamelas de chert após gipsita (seta preta). C) Gretas desenvolvidas nas lâminas de dolo-mudstone, escuras, e preenchidas por arenito fino dolomítico (claro); ocorrem nódulos de pseudomorfos de evaporitos na fração mais arenosa dentro das gretas (setas pretas) e na superfície dos dolo-mudstones (seta branca). D) Marcas de onda cortadas por duas gerações de gretas (setas). E) Arenito dolomítico com cavidades de pingos de chuva na superfície. F) Corte longitudinal de cavidade (seta preta) revestida por cimento gravitacional, formando possíveis dripstones no teto (setas brancas), e preenchida por dolo-mudstone, lâmina mais escura dentro do cimento no teto é composta de MO. G) Estromatólito estratiforme cumulativo rômbico (setas brancas) e retangular (seta preta). H) Mesmo estromatólito apresentando lineamento vertical de pirita e cavidades em forma de balão preenchidas por esparita, sugerindo escape de gases. I) Fotomicrografia da laminação interna de estromatólito estratiforme, com lâmina de chert (1) intercalada nas lâminas de dolo-mudstone (2), no topo ocorre uma série de cavidades em forma de balão interligadas e preenchidas por quartzo (seta preta); nicóis cruzados.

e quase ausência na superfície pode estar associada às inundações seguintes, responsáveis pela dissolução dos sais expostos. Também se sugere que o ambiente fosse redutor, com circulação restrita (água estagnada?), devido à presença intensa de pirita em aglomerados ou framboidal na fração lamosa. Neste contexto, admite-se que a dolomita presente seja primária ou eo-diagenética, como resultado da escassez de Ca, capturado na cristalização da gipsita e da anidrita.

$\mathrm{Na}$ base ocorre intercalação de dololutito laminado com gradação normal $(\mathrm{LI}(\mathrm{g})$ ) e dolorudito laminado $(\mathrm{RI})$. Os dololutitos são compostos de lâminas (1-6 milímetros) de dolo-mudstone com gradação normal, enquanto que os doloruditos compõem finas camadas (<10 centímetros) de floatstone contendo matriz lamosa e clastos lamelares de dolo-mudstones e MO. Estes clastos possuem um comprimento de até 1,5 centímetros e altura de até 0,1 milímetro. Este intervalo contém cavidades horizontais revestidas com várias gerações (até 4) de sílica criptocristalina e preenchidas por dolo-mudstone maciço. O cimento silicoso que reveste a cavidade parece ocorrer por substituição, sendo mais espesso no teto (dripstone?), formando concreções para o centro da cavidade e aprisionando as lamelas de MO sem substituílas (Prancha 9F).

As bioconstruções são facilmente reconhecidas a partir da metade da seção e se tornam mais frequentes para o topo. Esta fácies foi denominada dololutito com laminação biogênica (LIb). É composta de dolo-mudstone cinza, com laminação irregular, ondulada e/ou truncada, formando biostromas. Na porção intermediária da seção, os estromatólitos assumem aspecto estratiforme cumulativo, com lâminas 
internas incipientes, aparentemente lisas, com a forma laminar retangular à rômbica (Prancha 9G). Estes estromatólitos estratiformes ocorrem acima de doloarenito com estratificação cruzada e arenito dolomítico com marcas onduladas. Associados a este intervalo ocorrem piritas alinhadas verticalmente e pequenas cavidades com geometria em forma de balão, que sugerem escape de gases (Prancha 9H). Estas cavidades foram posteriormente preenchidas por doloesparita. Na porção mais de topo, ocorrem estromatólitos estratiformes que evoluem para formas dômicas e colunares. As formas estratiformes assumem geometria pseudocolunar a colunar-laminado, com laminação interna lisa convexa (Prancha 91). No topo destes estromatólitos estratiformes, ocorre silicificação parcial de substituição e de preenchimento de cavidades preexistentes (Prancha 9l). Estas cavidades possuem geometria sugestiva de intenso escape de gases. As formas colunares são inicialmente não ramificadas e evoluem para ramificadas, paralela, com laminação interna lisa, convexa (ramificadas) a parabólica (não ramificadas; Prancha 10A), com diâmetro entre 3 e 6 centímetros e altura de até 12 centímetros. Já os estromatólitos colunares ocorrem com intercalações de finas camadas de doloarenito oolítico e dolorudito intraclástico. Os estromatólitos do topo apresentam silicificação de substituição parcial a completa (Prancha 10B), observandose um aumento da sílica para o topo. No topo, ocorrem nódulos silicosos róseos, esféricos e com laminação interna concêntrica. Esta fácies foi interpretada como ambiente raso de águas límpidas, com sedimentação lenta, podendo ser redutor nos estromatólitos cumulados com pirita e oxigenado nos colunares rítmicos.

Na porção intermediária, a concentração de terrígenos na fração areia aumenta, ocorrendo camadas decimétricas de termos intermediários entre doloarenito impuro e arenito dolomítico, numa associação de fácies maciço conglomerático (Am (R)), com laminação plano-paralela (Al) e laminação cruzada cavalgante (Alc). A fácies Am (R) é composta derenito fino a médio, cimentado por esparita, ou por dolowackestone impuro, ambos róseos. Os clastos são esparsos, compostos de dolomudstone cinza claro a róseo, angulosos, de esfericidade variável, na fração de grânulos a seixo (Prancha $10 \mathrm{C}$ e D). A base da camada é geralmente erosiva e o topo gradacional para a fácies Al ou Alc. A fácies Al é composta dearenito dolomítico fino, cinza, cimentado por esparita, ou dolo-wackestone cinza, com laminação planoparalela em intervalos centimétricos e lineação de partição nos intervalos onde Am (R) está ausente (Prancha 10E). O contato de topo pode ser gradacional para a fácies Alc ou erosivo para a fácies $\mathrm{Am}(\mathrm{R})$. A fácies Alc tem a mesma composição da $\mathrm{Al}$, 
apresentando laminação cruzada cavalgante crítica e supercrítica (Prancha 10D), com migração para $W$ e contato de topo transicional para fácies mais finas. Estas fácies compõem várias seqüências de Bouma, com as unidades A-maciça, B-areia laminada e C-cruzada. Esta associação de fácies foi interpretada como o produto de correntes de turbidez em ambiente de inframaré, causados pela entrada de fluxos aquosos continentais episódicos, comuns em ambiente árido. Outra alternativa é a presença de relevo inclinado próximo ou a ocorrência de tempestades.

$\mathrm{Na}$ porção intermediária também ocorre dolorudito intraclástico $(\mathrm{R}(\mathrm{in}))$ em camadas centimétricas a decimétricas. Esta fácies é composta der dolo-packstone (floatstone?) intraclástico, com matriz de wackstone e intraclastos de dolo-mudstones. Os intraclastos possuem a geometria em placas, com espessura e comprimento máximos de 9 milímetros e 3 centímetros, respectivamente. Quando preenchendo canais, escavados em dolo-mudstones impuros, identifica-se em pulsos centimétricos (ao menos 3) com superfícies basais erosivas (Prancha 10F). O primeiro ocorre escavando a camada lamosa inferior e depositando placas (intraclastos) inclinadas, de litologia semelhante ao leito, com matriz insuficiente para cobrir aqueles que estão subverticalizados, mas coberto com uma fina cobertura lamosa. O segundo pulso erode parte da cobertura lamosa do primeiro pulso, com a deposição de dois tipos principais de intraclastos misturados, de dimensões menores e subparalelos ao acamamento. A deposição deste segundo pulso remove parte da matriz do primeiro pulso, expondo, afinando, flexionando e rompendo as extremidades expostas dos clastos pretéritos. Um terceiro pulso erosivo deposita intraclastos maiores, predominantemente róseos, subparalelos ao acamamento ou contorcidos, quando próximos à borda do canal, chegando a ocorrer feições cisalhantes nas paredes, com filmes de óxido de ferro recobrindo as superfícies. A disposição dos clastos sugere uma deposição por correntes, com turbilhamento na parede do canal. Em intervalos em que uma cobertura lamosa está preservada, os intraclastos estão horizontalizados, gradando para dolomudstone maciço com grãos de quartzo, depositado em ângulo com o acamamento do dolo-packstone. Os grãos de quartzo são cristalinos, subesféricos, arredondados a subangulosos (Prancha 10G). Esta fácies foi interpretada como depósitos episódicos gerados por erosão e deposição das lâminas gretadas, possivelmente por tempestades, em ambiente de intermaré.

Para o topo da seção, ocorrem camadas centimétricas a decimétricas de doloarenito oolítico com gradação normal $(\mathrm{Ag}(\mathrm{oo}))$ ou apresentando laminação 

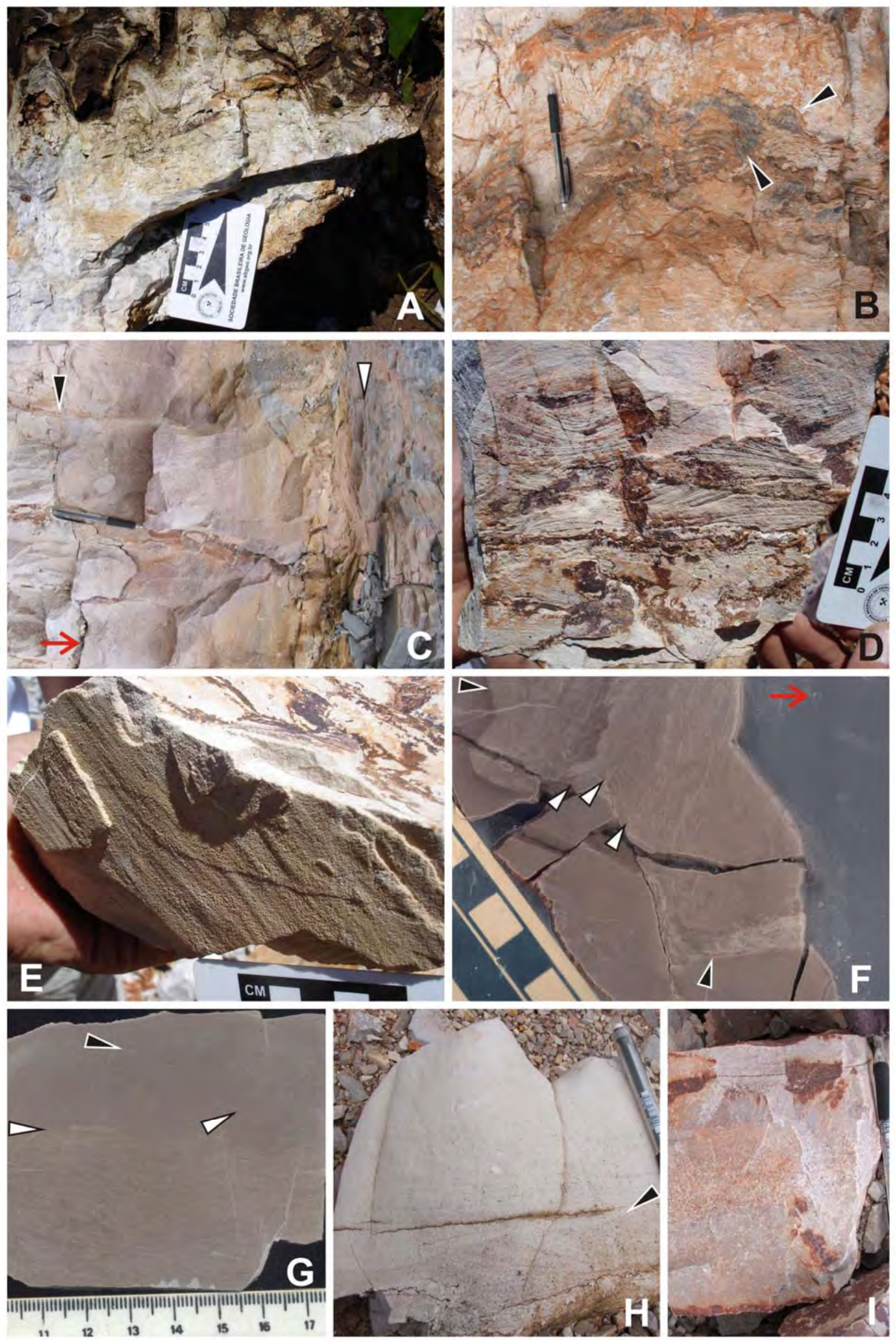

|

11 $12 \quad 13 \quad 14$ is 15 
Prancha 10: Exemplares litológicos da Formação Nobres. As fotografias estão orientadas com o topo para cima, salvo quando indicado pela seta vermelha. Seção 8: A) Estromatólito estratiforme (base) a colunar parabólico (topo). B) Estromatólito colunar com silicificação de substituição parcial no topo (setas). C) Seqüência de Bouma com base erosiva (seta preta), seguida por arenito dolomítico com clastos de dolo-mudstone, doloarenito laminado, ondulado e capeado por dolomudstone impuro laminado. D) Seqüência de Bouma apresentando as unidades maciça (base) e cruzada cavalgante. E) Base da mesma amostra em D, com lineação de partição. F) Canal escavado em dolo-mudstone (seta preta) e preenchido por, ao menos, 4 pulsos deposicionais; as setas brancas mostram os limites entre os pulsos; seta vermelha indica o topo. G) Dolo-packstone seguido de dolo-mudstone contendo grãos de quartzo (seta preta); o contato apresenta-se horizontal a inclinado (setas). H) Dolo-grainstone oolítico com laminação cruzada em contato plano com dolo-grainstone maciço; o topo é incerto. I) Dolograinstone oolítico granodecrescente em finas camadas com base erosiva.

cruzada (Ac (oo)), em pacotes rítmicos ou intercalados com as fácies Llb e R(in). São compostos de dolo-grainstones oolíticos, contendo intraclastos na fração areia grossa a fina. Os contatos são planares na fácies Ac (Prancha10H) e erosivo (serrilhado) na fácies Ag (Prancha 10l). A fácies Ag foi interpretada como depósitos gravitacionais, enquanto a fácies Ac sugere deposição por corrente, em canais de inframaré.

\subsubsection{Ambiente Deposicional do Grupo Araras}

As associações de fácies descritas acima permitem a identificação de diversos ambientes deposicionais para o Grupo Araras, que varia de marinho profundo a transicional. De maneira geral, observa-se uma tendência de arrasamento para o topo, conforme a bacia é preenchida ao longo de aproximadamente $50 \mathrm{Ma}$. Os ambientes serão descritos em dois itens, separados por formações. Como foram identificadas apenas duas das quatro formações de Nogueira \& Riccomini (2006), a seguir discutemse as interpretações paleoambientais das formações Guia e Nobres.

\subsubsection{Formação Guia: ambiente profundo}

No domínio tectônico externo da Faixa Paraguai, a deposição carbonática se inicia com dolomitos distintos daqueles reconhecidos no domínio tectônico cratônico como carbonatos de capa (Formação Mirassol d'Oeste de Nogueira et al., 2003), sendo tratados aqui como base da Formação Guia.

Na área de estudo, a porção mais basal da Formação Guia é constituída de turbiditos dolomíticos nas seções mais distais (Seção 3) e dolomito laminado contendo estromatólitos nas menos distais (Seção 2), evoluindo para fácies pelágicas ricas em $\mathrm{MO}$, argila e chert negro, com acamamento truncado ou com slumps associados. Este 
conjunto de fácies foi interpretado como de ambiente de talude para a região de Nobres e de margem de bacia para a região de Planalto da Serra. A evolução destas fácies ao longo das seções sugere uma retrogradação do talude. Nas Seções 4 e 5, sugerem-se condições iniciais oxigenadas, com luz solar suficiente ao desenvolvimento de estromatólitos colunares e cônicos, sob possível ação episódica de tempestades, que evoluem para condições anóxicas com importante influência de fluxos gravitacionais distais. Na Seção 3, predominam condições anóxicas deste o início, com a deposição de turbiditos ricos em MO, na base, e intervalos rítmicos, com chert negro de substituição das lâminas carbonosas. Assim, interpreta-se que estas seções sejam crono-correlatas, estando a Seção 3 em ambiente mais profundo que a Seção 2.

O restante da Formação Guia é depositado sob a influência de vários ciclos transgressivos/regressivos de pequena amplitude, observando-se uma tendência regressiva de maior amplitude. Estas variações menores do nível do mar são observadas na alternância de folhelhos, brechas, slumps e ritmitos (Seções 4 e 5), que foram interpretados como uma evolução do ambiente de margem de bacia para talude inferior (e.g.: Mullins \& Neumann, 1979). Na porção intermediária da Formação Guia, predominam os depósitos por decantação (folhelhos), com pouca tração (ritmitos), típicos de relevo plano com pouca elevação, enquanto que nas porções de topo atuam frequentemente processos de fluxo gravitacional (slumps e brechas), predominando fluxo de detritos e correntes de turbidez associados a deslizamentos, indicando terreno inclinado. Neste intervalo superior, o aumento da freqüência de clastos carbonáticos mais claros e dolomíticos nas brechas mostra uma maior proximidade da margem plataformal, para o topo.

Para a Formação Guia, assumiu-se um modelo deposicional de fluxo gravitational submarino (semelhante ao de Krausse \& Oldershaw, 1979), na região de Nobres. Esta interpretação se baseia na ocorrência marcante de slumps, brechas, turbiditos e pelágicos em camadas extensas, não se observando canais típicos de uma seqüência de leque submarino nas seções estudadas. Para a região de Planalto da Serra não se pôde tirar conclusões, pois as exposições não permitiram identificar a geometria das camadas, nem fácies de fluxo de detrito. Assim, os turbiditos identificados podem representar tanto porções distais de leques submarinos (ver Cook \& Egbert, 1981), quanto de fluxo de detritos. 


\subsubsection{Formação Nobres: ambientes raso e transicional}

As três seções estudadas da Formação Nobres mostraram associações de fácies de ambiente aquoso raso, com períodos de exposição subaérea. Da base para o topo, a associação de brechas e estromatólitos em biohermas mostra deposição em ambiente fótico, com importante contribuição de fluxo de detritos (Seções 6 e 7), mostrando raseamento para o topo. Esta associação foi interpretada como ambiente de banco oolítico com forte desenvolvimento de esteiras ou recife externo. A evolução das biohermas para esteiras estratiformes, juntamente com o aumento de areias oolíticas, mostram um aprofundamento para o topo e foram considerados como progradação de ambientes mais protegidos, como uma laguna (Seção 7). Para o topo, predominam intraclastos e oólitos estratificados, com laminações cruzadas em direções opostas, que sugerem um ambiente de inframaré, mostrando uma nova seqüência de raseamento. Assim, tem-se na Seção 7 uma sucessão progradacional da porção intermediária da Formação Nobres.

A Seção 8 contém parte da sucessão de topo da Formação Nobres e apresenta uma ampla variedade de fácies de ambiente marinho raso a continental. Este ambiente transicional foi interpretado como uma planície de maré retrogradacional. Na base da seção, predominam acamamento heterolítico com gretas de contração, pseudomorfos de sílica após gipsita e anidrita, esta última em camadas contorcidas, com ocorrência de pingos de chuva em camada arenosa. Estas características são diagnósticas de ambientes de supramaré a intermaré superior em regiões áridas, semelhantes aos ambientes atuais de planície de maré tipo sabkha, como Abu Dhabi, no Golfo Árabe (Evans et al., 1969; Kendall \& Skipwith, 1969; Schneider, 1975).

Na porção intermediária da Seção 8, predominam acamamento heterolítico com a fração silte/areia apresentando marcas de onda e microlaminação cruzada cavalgante, com gretas de contração e nódulos de pseudomorfo de quartzo após anidrita em menor freqüência. Ocorrem alguns estromatólitos estratiformes e canais preenchidos com clastos imbricados de dolo-mudstone (tempestitos?). O conjunto destas feições foi interpretado como ambiente predominantemente de intermaré, com tempestades episódicas (Shin, 1982), embora a distinção entre intermaré e supramaré seja difícil e exija o máximo de critérios possível (Demicco \& Hardie, 1994).

Para o topo, os estromatólitos se tornam mais expressivos, com crescimento vertical pronunciado, e intercalam calcarenitos oolítico-intraclásticos com laminações 
cruzadas e turbiditos com base erosiva. As gretas de contração e os pseudomorfos após evaporitos desaparecem. A interpretação para esse conjunto de fácies é de um ambiente de inframaré, de água límpida e quente, turvadas em períodos de sedimentação por correntes de turbidez. Estas correntes turbulentas podem estar associadas à entrada de rios efêmeros turbulentos, gerados durante intensa precipitação pluviométrica em curto espaço de tempo, característica de ambientes áridos atuais (Alsharhan \& Kendall, 2002). Além dos rios efêmeros, estes turbiditos poderiam estar associados a tempestades ou furacões, bem como a fluxos de detritos vindos de encostas próximas inundadas por transgressão.

\subsection{ARTIGO 1: NOVA UNIDADE LITOESTRATIGRÁFICA REGISTRA GLACIAÇÃO EDIACARANA EM MATO GROSSO: FORMAÇÃO SERRA AZUL}

A descrição das fácies e a interpretação ambiental da Formação Serra Azul se encontra descrita no artigo apresentado seguir. 


\title{
Geologia
}

\section{Nova Unidade Litoestratigráfica Registra Glaciação Ediacarana em Mato Grosso: Formação Serra Azul}

\author{
New Lithostratigraphic Unit Records an Ediacaran Glaciation in \\ Mato Grosso State, Brazil: Serra Azul Formation
}

Milene Freitas Figueiredo' (milene.figueiredo@gmail.com), Marly Babinski' (babinski@usp.br), Carlos José de Souza Alvarenga² (alva1@unb.br), Francisco Egídio Cavalcante Pinho³ (aguapei@yahoo.com) 'Departamento de Mineralogia e Geotectônica - Instituto de Geociências - USP

R. do Lago 562, CEP 05508-080, São Paulo, SP, BR

${ }^{2}$ Instituto de Geociências - UnB, Brasília, DF, BR

${ }^{3}$ Departamento de Recursos Minerais - Instituto de Ciências Exatas e da Terra - UFMT, Cuiabá, MT, BR

Recebido em 10 de março de 2008; aceito em 23 de julho de 2008

Palavras-chave: Formação Serra Azul, Faixa Paraguai, glaciação, Neoproterozóico, Ediacarano.

\section{RESUMO}

Uma nova sucessão de diamictitos e siltitos foi encontrada acima dos carbonatos pós-Marinoanos do Grupo Araras, na porção norte da Faixa Paraguai, em afloramentos descontínuos. Esta nova unidade estratigráfica é denominada Formação Serra Azul neste trabalho, possui espessura muito variável, de 60 a $300 \mathrm{~m}$. Na seção tipo, os diamictitos foram depositados nos primeiros $70 \mathrm{~m}$ e possuem evidências glaciais, como clastos polimíticos facetados e estriados, enquanto que os siltitos ocorrem ao longo do restante da sucessão, sendo intercalados por camadas de arenito no topo. Este registro glacial é o primeiro encontrado na América do Sul que pode estar relacionado à Glaciação Gaskierana (582 Ma).

Keywords: Serra Azul Formation, Paraguay Belt, glaciation, Neoproterozoic, Ediacaran.

\section{ABSTRACT}

A new succession of diamictites and siltstones was found above post-Marinoan carbonates from the Araras Group in the northern Paraguay Belt (Brazil), in discontinuous outcrops. This new stratigraphic unit, named Serra Azul Formation in this work, has a variable thickness reaching up to 300 meters. The diamictites were deposited in the first $70 \mathrm{~m}$ and present glacial evidences, while the siltstones represent the upper part of the succession and show some sandstone layers towards the top of the succession. This glacial record is the youngest Neoproterozoic glacial event that has been found on South America and probably is related to Gaskiers Glaciation (582 Ma). 


\section{INTRODUÇÃO}

Durante o Neoproterozóico (1000 a 542 Ma), o clima da Terra sofreu profundas mudanças, que ficaram registradas sob a forma de sucessões de diamictitos glaciais e carbonatos depositados em muitos locais ao redor do mundo (Kirschivink, 1992). De acordo com a hipótese Snowball Earth (Kirschivink, 1992; Hoffman et al., 1998), isto significaria a alternância de eventos climáticos extremos, como a intercalação de períodos glaciais e de estufa, de âmbito mundial. Tais eventos glaciais podem ter colaborado com uma inibição da evolução de filos animais desenvolvidos, que mostram uma rápida evolução ("Explosão Cambriana") de metazoários esqueletais após o término dos eventos glaciais. Atualmente, são conhecidos pelo menos três eventos glaciais neoproterozóicos (Halverson et al., 2005): Sturtiano ( 725 Ma), Marinoano (635 Ma) e Gaskierano (582 Ma).

Dentro deste contexto, foram encontrados, na porção norte da Faixa Paraguai (Estado do Mato Grosso), diamictitos (Figueiredo et al., 2004) sobrepostos aos carbonatos pós-Marinoanos do Grupo Araras (Nogueira et al., 2003; Alvarenga et al., 2004). A primeira descrição destas rochas incluía uma camada de pelitos com alguns clastos esparsos, com ocorrência de manganês, depositados sobre o Grupo Araras (Ganzer e Figueiredo, 2004). A sucessão completa só veio a ser identificada por Figueiredo et al. (2004), que apontou evidências glaciais relacionadas aos diamictitos. Sua posição estratigráfica distinta, litologia característica e mapeabilidade na escala de 1:250.000 requer o estabelecimento de uma nova unidade estratigráfica, denominada Formação Serra Azul (Figueiredo et al., 2005; Alvarenga et al., 2007).

\section{GEOLOGIA REGIONAL}

A Faixa de Dobramentos Paraguai (Figura 1), localizada na borda sudeste do Craton Amazônico, é composta de rochas sedimentares depositadas sobre uma margem passiva durante o Neoproterozóico, submetidas a dobramento durante a Orogênese Brasiliana, no Cambriano Inferior.

A litoestratigrafia da porção norte da Faixa Paraguai (Figura 2) inclui as unidades: Grupo Cuiabá, Formação Puga, Formação Bauxi, Grupo Araras e Grupo Alto Paraguai. Neste trabalho, sugere-se a inclusão da Formação Serra Azul na base do Grupo Alto Paraguai.

O Grupo Cuiabá é formado, da base para o topo, por pelitos ricos em matéria orgânica e dolomitos sobrepostos por sedimentos glaciomarinhos e turbidíticos, como diamictitos, conglomerados, arenitos e folhelhos (Alvarenga e Trompette, 1992). Esta sucessão grada lateralmente para as formações Puga e Bauxi.
A Formação Bauxi é composta por diamictitos glaciais intercalados com camadas de siltitos, quartzitos e conglomerados (Alvarenga, 1988). A Formação Puga é composta principalmente por diamictitos glaciais depositados na área cratônica (Ribeiro Filho et al., 1975). Embora dados geocronológicos inexistam, estes depósitos glaciais são amplamente relacionados à Glaciação Marinoana (Nogueira, 2003; Trindade et al., 2003; Alvarenga et al., 2004; Font et al., 2005, 2006; Elie et al., 2007).

Acima da Formação Puga, depositaram-se cerca de $1.000 \mathrm{~m}$ (área plataformal) de carbonatos do Grupo Araras, dividido em duas formações por Almeida (1964), enquanto que Nogueira (2003) sugere quatro formações. Segundo Almeida (1964), a base do Grupo Araras seria composta por ca. $250 \mathrm{~m}$ de calcários da Formação Guia, enquanto que o restante da sucessão seria representada pelos dolomitos da Formação Nobres. De acordo com Nogueira (2003), o Grupo Araras é composto, da base para o topo, por $20 \mathrm{~m}$ de dolomitos de capa da Formação Mirassol d' Oeste (encontrados unicamente sobre a região cratônica), ca. $220 \mathrm{~m}$ de calcários da Formação Guia, ca. $150 \mathrm{~m}$ de brechas dolomíticas e dolarenitos da Formação Serra do Quilombo (encontrados na serra homônima) e $250 \mathrm{~m}$ de dolomitos da Formação Nobres. O Grupo Araras foi depositado inicialmente em plataforma profunda (calcários), passando à plataforma rasa e ambiente de sabkha (dolomitos) no topo (Almeida 1964; Nogueira et al., 2007).

A unidade superior da faixa consiste das rochas siliciclásticas do Grupo Alto Paraguai, dividido em duas formações: Raizama e Diamantino. A Formação Raizama é composta de conglomerados, arcóseos e arenitos, depositados sob influência de maré (Almeida, 1964; Ribeiro Filho et al., 1975). A Formação Diamantino é composta basicamente pela intercalação de folhelhos vermelhos, siltitos e arcóseos, constituindo depósitos tipo molassa (Hennies, 1966). Aqui se propõe a inclusão da Formação Serra Azul, descrita a seguir, na base do Grupo Alto Paraguai.

\section{FORMAÇÃO SERRA AZUL}

Esta nova unidade litoestratigráfica foi estabelecida com base no Código Brasileiro de Nomenclatura Estratigráfica (Petri et al., 1986), obedecendo aos critérios de: (i) uniformidade litológica; (ii) continuidade; (iii) mapeabilidade à escala 1:250.000.

Para a seleção do nome, utilizou-se o termo geográfico de uma feição natural (Serra Azul) bem conhecida na região.

A localização do estratótipo da unidade (Figura 1), onde um perfil norte-sul foi detalhadamente descrito, está entre as coordenadas UTM 0660714E/8388096N e 0660374E/8388741N, no flanco sul da Sinclinal Serra Azul 
(de eixo E-W e mergulho de $15-20^{\circ}$ para norte), na porção norte da Faixa Paraguai (Figueiredo et al., 2004).

A Formação Serra Azul sobrepõe-se aos dolomitos da Formação Nobres e sotopõe-se aos conglomerados e arenitos da Formação Raizama (Figura 2), sendo composta por uma espessa sucessão (250 a 300 m) de diamictitos recobertos por siltitos, com intercalações de arenitos finos no topo, descritos adiante. Sua exposição é restrita, pois geralmente se encontra coberta por depósitos de tálus recentes, provenientes da alteração dos arenitos da Formação Raizama, que sustentam as serras dessa região. Assim, os melhores afloramentos encontram-se mais comumente no interior de ravinas e em poucos cortes de estrada e cavas de mineração.

\section{Diamictitos}

A unidade mais basal é composta por diamictitos e possui uma espessura média de $70 \mathrm{~m}$. O contato basal não foi observado, da mesma forma que os depósitos de diamictitos não puderam ser individualizados dentro desta unidade. Os diamictitos apresentam-se maciços a pobremente estratificados, contendo clastos variados no tamanho, forma e composição, dispersos em matriz silto-argiloarenosa vermelha, intercalado com fina camada $(1 \mathrm{~cm}) \mathrm{de}$ arenito síltico.

Os clastos variam em tamanho desde seixos (ca. 5\%), blocos (ca. 1\%) a matacões $(<1 \%)$, angulosos a arredondados (Figura 3A), ocasionalmente facetados, polidos ou estriados (Figuras 3A a 3C). Alguns clastos arredondados apresentam marcas de impacto ou superfície plana de abrasão estriada, paralela ao longo do eixo maior, sugerindo se tratar de clastos fluviais retrabalhados pela geleira. Alguns clastos triangulares apresentam um dos cantos mais pontiagudos voltados para baixo, enquanto que um bloco grande e um matacão, em forma de ferro de passar, apresentam orientação do eixo maior para WNW (Figura 3B).

Os clastos são compostos predominantemente de silexitos, metarenitos e arenitos, ocorrendo também dolomitos, cherts negros e claros, quartzos leitosos, argilitos, arcóseos, rochas graníticas, diabásios, vulcânicas, gnaisses, quartzitos, metaconglomerados e granitos metamorfisados. No topo dos diamictitos, existe uma fina e persistente camada de ca. $60 \mathrm{~cm}$ de diamictito síltico amarelo (Figura 3D), com uma estratificação mais desenvolvida, muitos grânulos e alguns clastos arredondados e angulosos, na maioria compostos de quartzo, chert e quartzito.

Embora o contato basal dos diamictitos não esteja exposto, a presença de fragmentos de carbonatos e chert com características da Formação Nobres (fragmentos de estromatólito silicificado, dolomito oolítico, cherts associados a dolomito, pseudomorfos de gipsita) sugerem um contato basal erosivo. O contato superior com a sucessão de siltitos se dá de forma concordante e brusca.

\section{Siltito}

Sobreposta aos diamictitos, segue uma sucessão homogênea de aproximadamente $25 \mathrm{~m}$ de siltito argiloso micáceo vermelho, com laminação incipiente, cuja alteração desenvolve freqüentemente empastilhamento (Figura 3E), e ocorrência de esparsos grânulos granodecrescentes para o topo. O contato basal com os diamictitos é brusco, enquanto que o contato de topo é gradacional para uma sucessão rítmica. Na região da cidade de Nobres, logo na base dessa sucessão rítmica, ocorre uma camada lenticular de calcário.

\section{Camada carbonática}

Uma camada lenticular de calcário, depositada entre o siltito e os ritmitos, com $12 \mathrm{~m}$ de espessura, foi encontrada somente na cava de argila da fábrica de cimento Votorantin, nas proximidades da cidade de Nobres. O contato basal com os ritmitos apresenta ondulação irregular. As texturas e estruturas observadas neste calcário, da base para o topo, foram: calcilutito com laminação plano-paralela; calcilutito maciço (Figura 4A) com microcanais preenchidos com calciwackestone intraclástico; calcilutito laminado com textura grumosa; calcilutito com laminação truncada (Figura 4B); sucessões cíclicas de deformação por escorregamento e brechamento; e laminação plano-paralela, ocorrendo filmes de argila vermelha entre as lâminas, cujo aumento para o topo provoca deformação nodular do calcário (Figura 4B).

\section{Ritmitos}

Acima do siltito vermelho segue a deposição de ca. $150 \mathrm{~m}$ de ritmitos (Figura 4C). Na porção mais basal do pacote, ocorrem intercalações de camadas $(5 \mathrm{a} 10 \mathrm{~cm})$ de arenito fino com laminação plano-paralela recobertas por marcas onduladas e estratificação cruzada hummocky, sugerindo episódios de fluxo oscilatório (Figura 3F). Para o topo observa-se um desenvolvimento mais evidente da laminação e um aumento na quantidade de argila. Na porção intermediária dos ritmitos ocorre alternância de lâminas plano-paralelas de argila síltica $(2 \mathrm{~mm}$ a $3 \mathrm{~cm})$ e areia muito fina $(1 \mathrm{a} 5 \mathrm{~mm})$, recoberto por uma camada de $15 \mathrm{~cm}$ de arenito maciço médio, bem selecionado e com os grãos angulosos. Acima desta camada de arenito, é retomada a deposição rítmica, no entanto, com uma maior contribuição de areia fina, intercalando lâminas de silte (1 a $10 \mathrm{~mm})$ e areia fina $(2 \mathrm{~mm}$ a $2 \mathrm{~cm})$, gradando para um ritmito com intercalação de areia fina ( $3 \mathrm{~mm}$ a $1,5 \mathrm{~cm})$ e argila $(<1$ a $5 \mathrm{~mm}$ ). Para o topo, aumenta-se gradacionalmente a contribuição de areia, passando a uma sucessão heterolítica. 


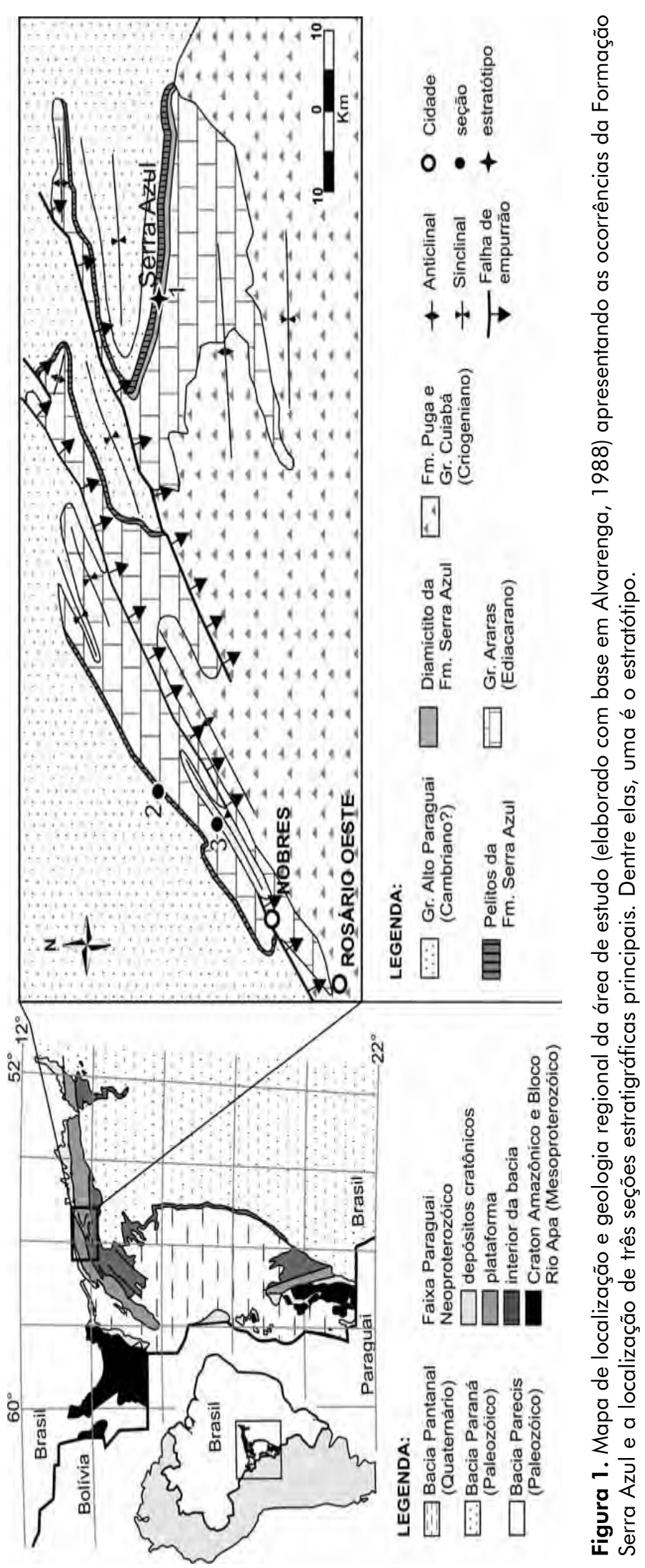



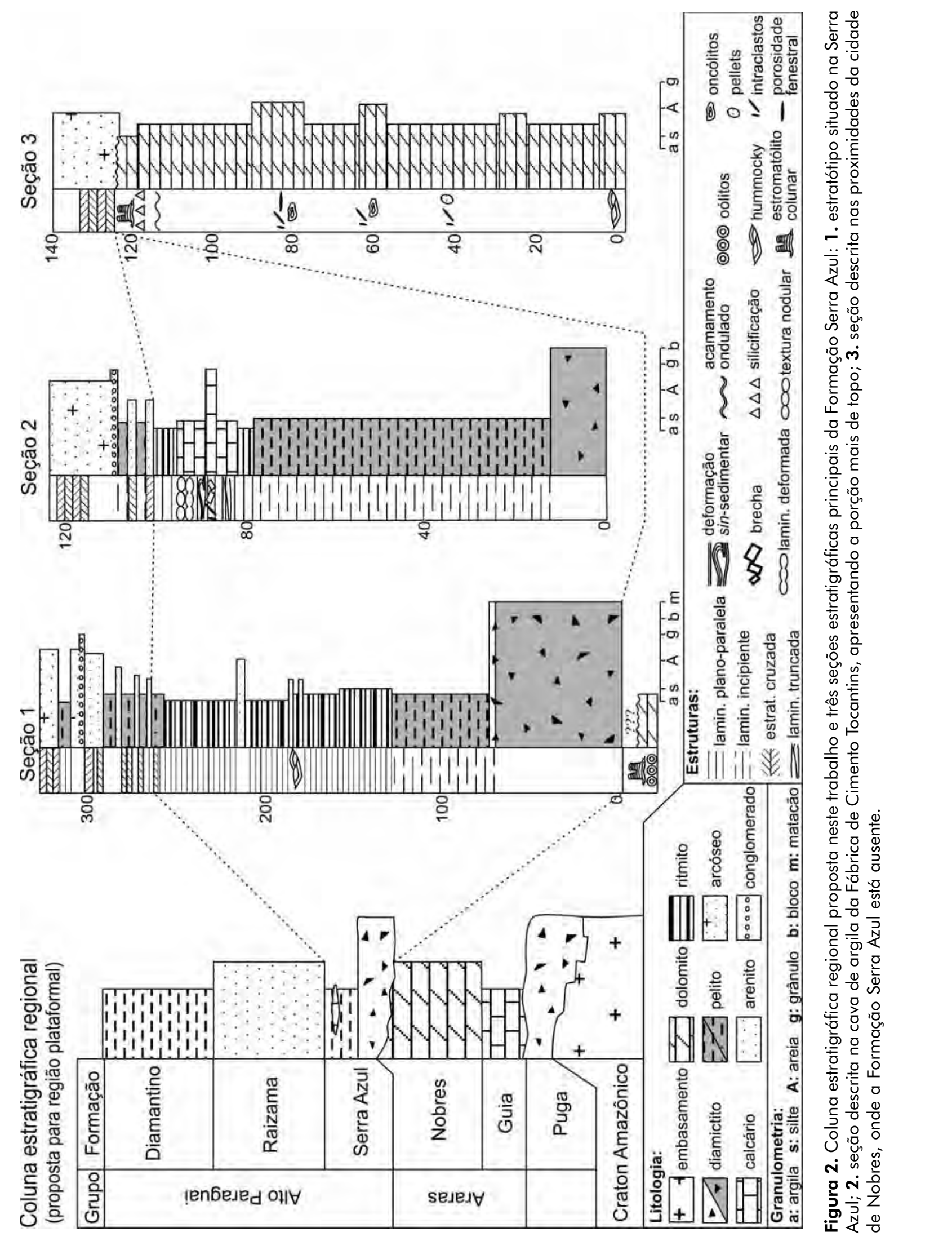

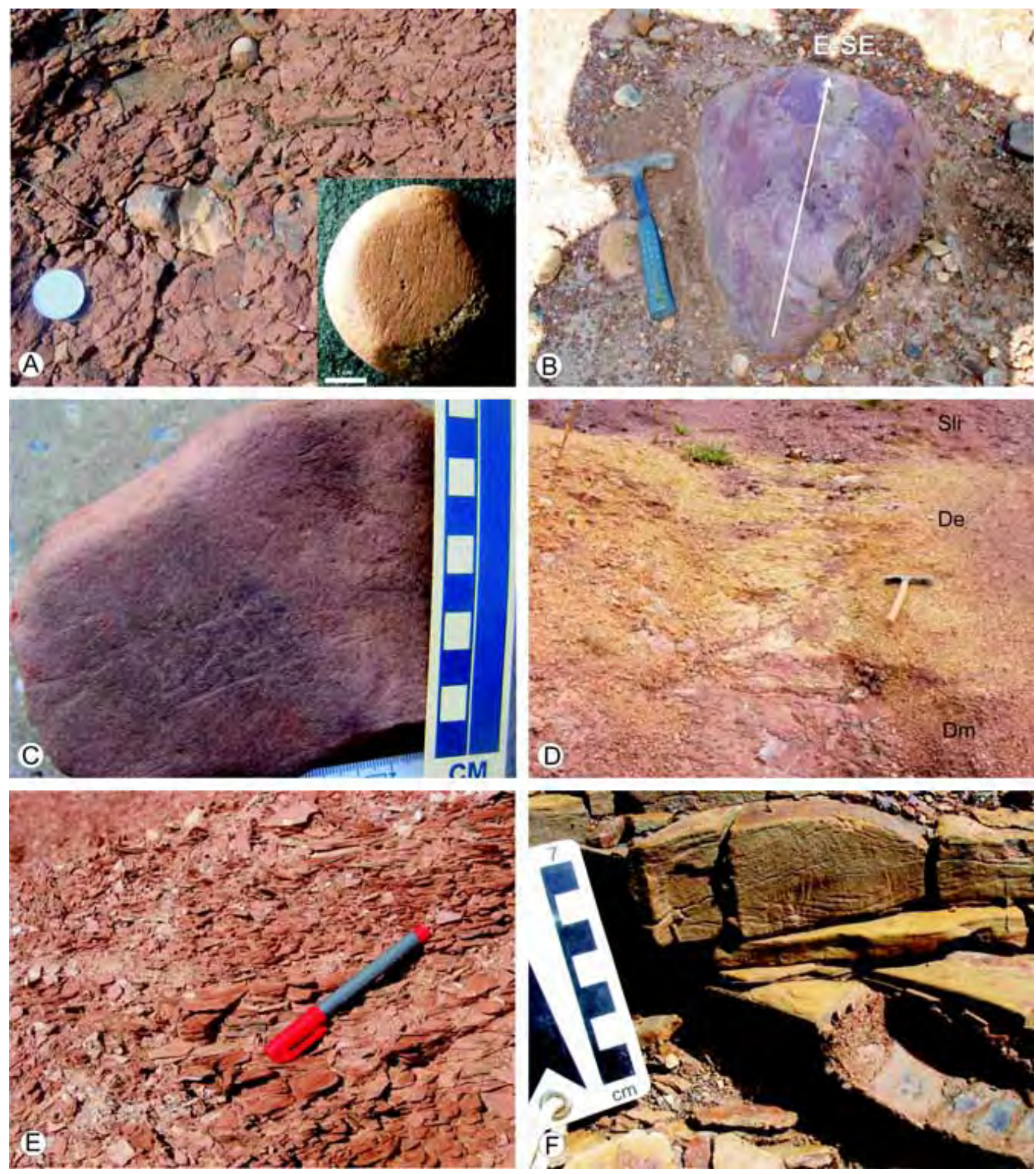

Figura 3. Prancha de fotografias em escala de afloramento: A. diamictito da Formação Serra Azul mostrando um clasto arredondado de arenito e outro anguloso de chert e carbonato, com detalhe para um clasto redondo com superfície plana de abrasão estriada dos dois lados; B. matacão em forma de ferro de passar (foto em planta, com indicação do norte) e detalhe de um clasto redondo com superfície plana de abrasão estriada dos dois lados (canto superior esquerdo); C. clasto de arenito arredondado e estriado; D. contato gradacional entre diamictito vermelho maciço (Dm) e diamictito amarelo estratificado (De) e brusco para siltito com laminação incipiente (Sli); E. porção de topo do siltito laminado vermelho; F. detalhe de estratificação hummocky em camada arenosa intercalada em ritmitos. 

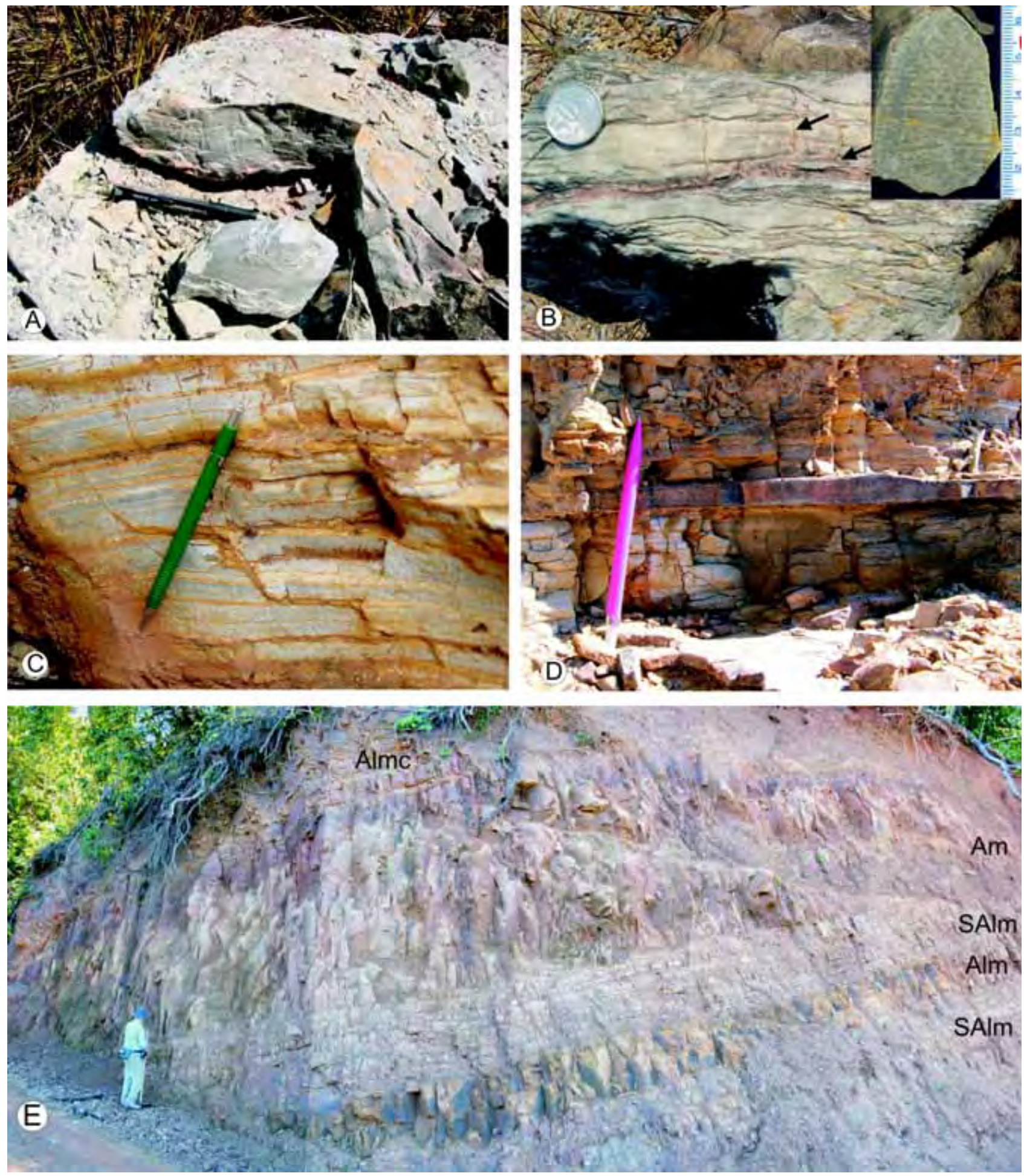

Figura 4. Prancha de fotografias em escala de afloramento: A. calcário maciço; B. mudstone mostrando deformação progressiva por compactação, as setas indicam as lâminas de argila rosa deformadas, com detalhe para lâminas deformadas evoluindo para uma textura nodular; C. ritmito com predomínio de argila (cinza); D. intercalação de camada de arenito tipo pinch and swell; $\mathbf{E}$. frente deltáica mostrando empilhamento de intercalação de siltito e arenito laminado (SAlm), arenito laminado em pequenos lobos (Alm), arenito maciço em lobos $(\mathrm{Am})$, arenito muito fino laminado apresentando micro sets sigmoidais com estratificação cruzada (Almc), sendo que o contato de topo da Formação Serra Azul é posto na base da camada Alm. 


\section{Sucessão heterolítica}

O pacote heterolítico, que se segue por aproximadamente $40 \mathrm{~m}$, é composto, na base, por siltito com estratificação plano-paralela com intercalações lenticulares de arenito fino com estratificação cruzada $(0,5$ a 2 cm). Na porção intermediária, observa-se a ocorrência cada vez mais freqüente de lâminas de arenito fino, por vezes com estratificação cruzada planoparalela (Figura 4D), espessando para o topo, passando a camadas decimétricas de arenito fino. No topo da sucessão observa-se a predominância de arenito em camadas métricas de geometria sigmoidal, apresentando laminação plano-paralela na camada inferior e maciça, cruzada planar e hummocky na superior, intercaladas por pacotes heterolíticos. O contato com a Formação Raizama é gradacional (Figura 4E), observando-se um aumento considerável na quantidade de ferro nos arenitos (cimento ferruginoso) de granulometria fina a média com estratificação cruzada (incluindo tipo espinha de peixe) de bandamentos de maré, nos conglomerados de arcabouço fechado (quartzo leitoso e feldspato de $0,5 \mathrm{a} 2 \mathrm{~cm}$ ), nos argilitos laminados intensamente impregnados por óxido de ferro e arenitos laminados ricos em hematita.

\section{AMBIENTE DEPOSICIONAL DA FORMAÇÃO SERRA AZUL}

Antes de discutir os possíveis ambientes deposicionais da Formação Serra Azul, é importante esclarecer que o termo diamictito utilizado neste trabalho é descritivo e não tem conotação genética, correspondendo a uma rocha composta por uma mistura de matriz e clastos variegados, pobremente selecionados (Eyles et al., 1983). Avaliando as evidências disponíveis, o aspecto maciço e mal selecionado do diamictito ora descrito indica uma deposição por fluxos aquosos de alta densidade (Edwards, 1978), sem qualquer retrabalhamento por correntes ou intercalação de camadas de outras litologias, que pudessem fornecer mais dados sobre seu ambiente deposicional.

Já a grande variedade composicional dos clastos aqui descritos exige um agente transportador capaz de varrer amplas regiões, a ponto de misturar diversos tipos litológicos ígneos, sedimentares e metamórficos (Eyles e Miall, 1984). Conjuntamente a isso, foi encontrada uma grande quantidade de clastos estriados, facetados (incluindo seixos fluviais) e polidos, além de dois grandes clastos (bloco e matacão) em forma de ferro de passar, que normalmente são tidos como evidências de ambientes glaciais (Eyles, 1993). No entanto, não foi possível identificar os pacotes individuais dos diamictitos amalgamados, nem mesmo pavimento estriado ou embasamento deformado, que pudessem indicar a deposição direta por uma geleira e a reclassificação destes diamictitos como tilitos (Eyles, 1983). Apesar disso, a orientação seme- lhante dos dois grandes clastos em forma de ferro de passar (Figura 3B), com a ponta mais alongada para W-NW, poderia indicar um sentido de deslocamento da geleira para E-SE, ou seja, do paleocontinente (Craton Amazônico) para o paleoceano (Faixa Paraguai). Diante do exposto, as evidências são suficientes para indicar uma deposição destes diamictitos sob influência glacial, ainda que remota.

Levando-se em consideração o ambiente marinho raso a transicional (planície de maré) do topo da Formação Nobres (Nogueira, 2003), sotoposta aos diamictitos, e a estabilidade da margem continental do paleocontinente, pode-se sugerir que os diamictitos tenham se depositado num ambiente glacio-marinho raso a transicional.

A deposição de um espesso pacote de siltito laminado diretamente sobre os diamictitos indica a interrupção de fluxos de alta densidade e um aumento da profundidade, podendo estar associada ao recuo da geleira por degelo e conseqüente elevação do nível do mar.

Ao longo desta sucessão de siltitos não é possível reconhecer quando a glaciação se finda, mas a ocorrência da camada de calcário, na região de Nobres, depositada logo acima sugere uma interrupção da deposição clástica, marcando uma superfície de máxima inundação, possivelmente relacionada ao completo degelo e ao aquecimento do clima. A base desta camada de calcário é irregular, como resultado da deformação plástica dos siltitos sotopostos, evidenciando uma rápida deposição dos carbonatos sobre os sedimentos ainda inconsolidados. Isto pode ser ainda observado, pela ocorrência de estruturas de deformação sedimentar plástica, dentro da camada de calcário (microdobras e textura nodular por compressão).

Na região da Serra Azul, o siltito laminado grada para uma espessa sucessão rítmica, depositada em ambiente profundo, fora do alcance da base das ondas de tempo bom. Esporadicamente este ambiente é perturbado por ondas de tempestades, evidenciado pela presença de camadas arenosas com estratificação hummocky de pequeno porte bem preservadas, o que sugere uma deposição de off shore.

Acima desta sucessão rítmica agradacional segue-se uma sucessão heterolítica progradacional, marcada pela intercalação de camadas de areia fina cada vez mais espessas e freqüentes para o topo, assim como uma nítida diminuição na contribuição de finos, com ocorrência de lobos arenosos e bandamentos de maré bem preservados. Esta configuração é bastante semelhante a uma seqüência deltáica progradacional (Galloway, 1975), com características de: (i) pró-delta sem influência de ondas na base (deposição plano-paralela de silte e argila, aparentemente rítmica); (ii) frente deltáica na porção intermediária, com a predominância de lobos arenosos intercalados por sucessões heterolíticas de silte-areia; (iii) planície deltáica no topo, evidenciada por depósitos arenosos de inframaré e supramaré, com bandamentos de maré intercala- 
dos por argilitos com laminação plano-paralela (planície deltáica inferior) e conglomerados fluviais intercalados com arenito grosso (possíveis canais distributários na planície de maré superior).

Ao longo dessa sucessão ocorre a transição entre as formações Serra Azul e Raizama, sendo extremamente difícil estabelecer a linha de contato entre as duas devido ao caráter extremamente gradacional dessa sucessão, tendo-se estabelecido, arbitrariamente, o início na Formação Raizama na base da primeira camada arenosa lobular (Figura 4E).

\section{ESTRATIGRAFIA}

Com relação à estratigrafia, a proposta de classificar esta unidade como formação é inevitável diante de sua expressividade, uniformidade litológica, continuidade e mapeabilidade (Petri et al., 1986) ao longo da Faixa Paraguai Norte. Além disso, esta unidade traz uma nova abordagem na compreensão da evolução paleoambiental local e implicações no entendimento do comportamento climático da Terra durante o Ediacarano.

Por constituir uma unidade quase totalmente terrígena (empilhamento de siltitos e arenitos) que se assemelha às formações sobrejacentes, Raizama e Diamantino (exceto pela ocorrência de diamictitos na base), sugere-se que a Formação Serra Azul seja incluída no Grupo Alto Paraguai. Esta proposta é motivada pelo Código Brasileiro de Nomenclatura Estratigráfica (Petri et al., 1986), o qual orienta que as formações pertencentes a um grupo devem ser relacionadas por características ou feições litoestratigráficas comuns, o que se confere entre as formações do Grupo Alto Paraguai e a Formação Serra Azul, ao contrário do que ocorre com o Grupo Araras sotoposto, constituído predominantemente por rochas carbonáticas.

\section{CONTEXTO DAS GLACIAÇÕES NEOPROTEROZÓICAS}

O Grupo Araras tem sido correlacionado com sucessões carbonáticas pós-Marinoanas através de curvas isotópicas (Nogueira et al., 2003; Alvarenga et al., 2004; Figueiredo, 2006), fazendo com que os diamictitos sotopostos da Formação Puga sejam correlacionados à chamada Glaciação Marinoana (635 Ma; Hoffmann et al., 2004), considerada de abrangência global, segundo a Hipótese Snowball Earth (Hoffman et al., 1998). Assim, a existência de um segundo depósito glacial na Faixa Paraguai Norte, situado logo acima de uma sucessão pós-Marinoana, sugere que os diamictitos da Formação Serra Azul possam ser correlacionados a uma glaciação neoproterozóica mais jovem, a Glaciação Gaskierana (582 Ma; Bowring et al., 2003). No entanto, os registros de um ciclo hidrológico ativo (estratificações hummocky e cruzadas) apresentados são contrários ao ambiente proposto pela Hipótese Snowball Earth, extremamente frio e árido, capaz de gerar uma camada de gelo que isole os oceanos da atmosfera.

A Formação Gaskiers, conjuntamente aos Diamictitos Varanger na Escandinávia, era considerada como o registro de um evento glacial regional centrado no Atlântico Norte (Halverson et al., 2005). Porém, sucessões de mesma idade vêm sendo correlacionadas com a Glaciação Gaskierana, como o Grupo Nafun, em Oman (Cozzi et al., 2004; Brasier et al., 2000), a Formação Wonoka, na Austrália (Calver, 2000), a Johnnie, nos Estados Unidos (Corsetti e Kaufman, 2003), e a Sierra Del Volcán, na Argentina (Pazos et al., 2008).

Tratando-se da correlação entre a Formação Serra Azul e a Formação Gaskiers, em Newfoundland (Bowring et al., 2003), estudos paleomagnéticos mostram um possível modelo paleogeográfico, embora ainda imprecisos para a idade de $580 \mathrm{Ma}$, no qual o paleocontinente Laurentia e os fragmentos que gerariam o paleocontinente Gondwana, em especial o Craton Amazônico, estariam bastante próximos uns dos outros e situados em altas latitudes (Trindade e Macouin, 2007). Isso sugere que a Formação Serra Azul faça parte de um possível evento glacial regional de altas latitudes, como resultado da reunião de boa parte dos paleocontinentes nas proximidades do pólo.

\section{AGRADECIMENTOS}

Agradecemos aos colegas que participaram de algumas das etapas de campo e deram importantes contribuições, Paulo César Boggiani, Thomas Rich Fairchild, Roberto Ventura Santos, Cyntia Moraes Simon e, em especial, ao professor Antonio Carlos Rocha Campos pelas importantíssimas ponderações sobre a sedimentologia glacial, em campo e no escritório. As sugestões feitas por dois revisores anônimos contribuíram para a melhoria do manuscrito. A identificação desta unidade foi realizada durante o mestrado da autora sênior, que teve bolsa da Fundação de Amparo à Pesquisa de São Paulo (FAPESP; Proc. 04/06225-5), continuando sua pesquisa no doutorado, com bolsa do Conselho Nacional de Desenvolvimento Científico e Tecnológico (CNPq; Proc. 140359/2006-0). Esta pesquisa foi financiada pelo CNPq (Proc. 473614/2004-9) e FAPESP (Proc. 05/58688-1).

\section{REFERÊNCIAS BIBLIOGRÁFICAS}

ALMEIDA, F. F. M. Geologia do centro-oeste matogrossense. Ministério de Minas e Energia, Departamento Nacional de Produção Mineral, Boletim da Divisão de Geologia Mineral, v. 215, p. 1-137, 1964.

ALVARENGA, C. J. S. Turbiditos e a glaciação do final do 
proterozóico superior no Cinturão Paraguai, Mato Grosso. Revista Brasileira de Geociências, v. 18, p. 323-327, 1988.

ALVARENGA, C. J. S.; TROMPETTE, R. Glacial influenced turbidite sedimentation in the uppermost proterozoic and lower cambrian of the Paraguay Belt (Mato Grosso, Brazil). Palaeogeography, Palaeoclimatology, Palaeoecology, v. 92, p. 85-105, 1992.

ALVARENGA, C. J. S.; SANTOS, R. V.; DANTAS, E. L. C-O$\mathrm{Sr}$ isotopic stratigraphy of cap carbonates overlying marinoan-age glacial diamictites in the Paraguay Belt, Brazil. Precambrian Research, v. 131, p. 1-21, 2004.

ALVARENGA, C. J. S.; FIGUEIREDO, M. F.; BABINSKI, M.; PINHO F. E. C. Glacial diamictites of Serra Azul Formation (Ediacaran, Paraguay Belt): evidence of the Gaskiers glacial event in Brazil. Journal of South American Earth Science, v. 23, p. 236-241, 2007.

BOWRING, S.; MYROW, P.; LANDING, E.; RAMEZANI, J.; GROTZINGER, J. Geochronological constraints on terminal neoproterozoic events and rise of metazoans. Geophysical Research Abstracts, v. 5, p. 13219, 2003.

BRASIER, M.; MCCARRON, G.; TUCKER, R.; LEATHER, J.; ALLEN, P.; SHIELDS, G. New U-Pb zircon dates for the neoproterozoic ghubrah glaciation and for the top of the Huqf Supergroup, Oman. Geology, v. 28 , p. $175-178,2000$.

BURNS, S. J.; MATTER, A. Carbon isotopic record of the latest proterozoic from Oman. Eclogae Geologicae Helviticae, v. 86, p. 595-607, 1993.

COZZI,A. ; ALLEN, P.A. ; GROTZINGER, J. P. Understanding carbonate ramp dynamics using $\delta^{13} \mathrm{C}$ profiles: examples from the neoproterozoic Buah Formation of Oman. Terra Nova, v. 16, p. $62-67,2004$

CORSETTI, F.A. ; KAUFMAN, A. J. Stratigraphic investigations of carbon isotope anomalies and neoproterozoic ice ages in Death Valley, California. Bulletin of the Geological Society of America, v. 115 n. 8, p. 916-932, 2003.

EDWARDS, M. B. Glacial environments. In: READING, H.G. (Ed). Sedimentary environments and facies. New York: Elsevier, 1978. p. 416-438.

ELIE,M.;NOGUEIRA,A.C.R.; TRINDADE, R.I.F; NÉDÉLEC, A.; KENIG, F. A red algal bloom in the Marinoan snowball Earth. Terra Nova, v. 19, p. 303-308, 2007.
EYLES, N. Earth's glacial record and its tectonic setting. Earth Science Reviews, v. 35, n. 1/2, p. 1-248. 1993.

EYLES, N.; EYLES, C. H.; MIALL, A. D. Lithofacies types and vertical profile models: and alternative approach to the descriptions and environmental interpretation of glacial diamict sequences. Sedimentology, v. 30, p. 393-410, 1983.

EYLES, N.; MIALL, A. D. Glacial facies. In: WALKER, R. G. (Ed) Facies models. 2. ed. Geoscience Canada, , 1984. p. 15-38 (Reprint Series 1).

FIGUEIREDO, M. F. Quimioestratigrafia das rochas ediacarianas do extremo norte da Faixa Paraguai, Mato Grosso. 2006. 105 f. Dissertação (Mestrado) - Instituto de Geociências, Universidade de São Paulo, São Paulo, 105 p.

FIGUEIREDO, M. F.; BABINSKI, M.; ALVARENGA, C. J. S.; PINHO, F. E. C. Diamictites overlying Marinoan-age carbonates of Araras Formation, Paraguay Belt, Brazil: evidence of a new glaciation? In: SYMPOSIUM ON NEOPROTEROZOIC-EARLYPALEOZOICEVENTS INSWGONDWANA, 2, 2004, São Paulo. Anais... São Paulo: IGCP, 2004.p. 18-19.

FIGUEIREDO, M. F.; BABINSKI, M.; ALVARENGA, C. J. S., PINHO, F. E. C. Nova unidade litoestratigráfica: Formação Serra Azul, Faixa Paraguai, Mato Grosso. In: SIMPÓSIO DE GEOLOGIA DO CENTRO-OESTE, 9., 2005, Goiânia. Anais... Goiânia: SBG-Centro Oeste, 2005. p. 23-25.

FONT, E. Paleomagnetismo dos carbonatos de capa do Cráton Amazônico (Brasil): implicações para as glaciações do Neoproterozóico. 2005. 203 f. Tese (Doutorado) - Instituto de Astronomia, Geofísica e Ciências Atmosféricas, Universidade de São Paulo, São Paulo, 2005.

FONT,E.; TRINDADE, R. I.F.; NÉDÉLEC,A. Remagnetization in bituminous limestones of the neoproterozoic Araras Group (Amazon craton): hydrocarbon maturation, burial diagenesis, or both? Journal of Geophysical Research B: Solid Earth, v. 111, art. n. B06204, 2006.

GANZER, E. B.; FIGUEIREDO, M. F. Mapeamento geológico e estudo geoquímico do Grupo Alto Paraguai, Marzagão-MT. 2004. 123 f. Trabalho de Conclusão de Curso (Graduação) - Instituto de Ciências Exatas e da Terra, Universidade Federal de Mato Grosso, Cuiabá, 2004.

GALLOWAY, W. E. Process framework for describing the morphologic and stratigraphic evolution of the deltaic depositional systems Deltas. In BROUSSARD, M. L. (Ed). 
Deltas. Houston: Houston Geological Society, 1975. p. 87-98.

HALVERSON, G. P.; HOFFMAN, P. F.; SCHRAG, D. P.; MALOOF, A. C. Toward a neoproterozoic composite carbonisotope record. Bulletin of the Geological Society of America, v. 117, p. 1181-1207, 2005.

HENNIES, W. T. Geologia do centro-norte Mato-Grossense. 1966. 65 f. Tese (Doutorado) - Escola Politécnica, Universidade de São Paulo, São Paulo, 1966.

HOFFMAN, P. F.; KAUFMAN, A. J.; HALVERSON, G. P.; SCHRAG, D. P. A neoproterozoic snowball Earth. Science, v. 281, p. 1342-1346, 1998.

HOFFMANN, K-H.; CONDON, D. J.; BOWRING, S. A.; CROWLEY, J. L. U-Pb zircon date from the neoproterozoic Ghaub Formation, Namibia: constraints on Marinoan glaciation. Geology, v. 32, p. 817-820, 2004.

KIRSCHVINK, J. L. Late proterozoic low-latitude global glaciation: the snowball Earth. In: SCHOPF, J. W.; KLEIN, C. (Ed.). The proterozoic biosphere - a multidisciplinary study. Cambridge University Press, 1992. p. 51-52.

NOGUEIRA, A. C. R. A plataforma carbonática Araras no sudoeste do Cráton Amazônico, Mato Grosso: estratigrafia, contexto paleoambiental e correlação com os eventos glaciais do neoproterozóico. 2003. 173 f. Tese (Doutorado) - Instituto de Geociências, Universidade de São Paulo, São Paulo, 2003.

NOGUEIRA,A.C.R.; RICCOMINI, C.; SIAL,A. N.; MOURA, C. A. V.; FAIRCHILD, T. R. Soft-sediment deformation at the base of the neoproterozoic Puga cap carbonate (southwestern Amazon craton, Brazil): confirmation of rapid icehouse to greenhouse transition in snowball Earth. Geology, v. 31, p. 613-616, 2003.

NOGUEIRA, C. R.A.; RICCOMINI, C.; SIAL,A. N.; MOURA, C.A. V.; TRINDADE, R. I. F.; FAIRCHILD; T. R. Carbon and strontium isotope flutuations and paleoceanographic changes in the late neoproterozoic Araras carbonate platform, southern Amazon Craton, Brazil. Chemical Geology, v. 237, p. 168-190, 2007.

PAZOS, P. J.; BETTUCCI, L. S.; LOUREIRO, J. The neoproterozoic glacial record in the Río de la Plata Craton: a critical reappraisal. Geological Society, London, v. 294, p. 343-364, 2008. Special Publications.

PETRI, S.; COIMBRA, A. M.; OJEDA, H. O.; FULFARO, V. J.; PONÇANO, W. L. Guia de nomenclatura estratigráfica.
Revista Brasileira de Geociências, v. 16, p. 376-415, 1986.

RIBEIROFILHO, W.; LUZ, J.S.; ABREUFILHO, W. Relatório final do Projeto Serra Azul. Brasília: Ministério de Minas e Energia, Departamento Nacional de Produção Mineral e Companhia de Pesquisa de Recursos Minerais, 1975. 104 p. v. 1.

TRINDADE, R. I. F.; MACOUIN, M. Palaeolatitude of glacial deposits and palaeogeography of neoproterozoic ice ages. C.R. Geoscience, v. 339, p. 200-211, 2007. 



\section{CAPÍTULO 4 GEOQUÍMICA ISOTÓPICA}

Este capítulo apresenta a quimioestratigrafia isotópica de $\mathrm{C}, \mathrm{O}, \mathrm{Sr}$ e $\mathrm{S}$ dos carbonatos da Faixa Paraguai Norte na forma de dois artigos a serem submetidos em revistas científicas de ampla circulação. As composições isotópicas de C, O e Sr foram obtidas em amostras coletadas em nove seções estratigráficas representativas das formações Guia, Nobres e Serra Azul. Em amostras de quatro destas seções foram determinadas as composições isotópicas de S (sulfato e sulfeto) e C orgânico. Para um melhor entendimento, a numeração das seções estratigráficas mencionadas no Artigo 2 (item 4.1) segue a mesma utilizada no Capítulo 3, para que o leitor tenha acesso às respectivas descrições litológicas detalhadas e interpretações ambientais.

\subsection{ARTIGO 2: QUIMIOESTRATIGRAFIA ISOTÓPICA (C, 0 e $\mathrm{Sr})$ DE CARBONATOS DA FAIXA PARAGUAI NORTE}

Milene F. Figueiredo e Marly Babinski

Instituto de Geociências, Universidade de São Paulo (USP), São Paulo, SP - Brasil. E-mail: milene.figueiredo@gmail.com, babinski@usp.br

\section{RESUMO}

Incursões fortemente negativas de $\delta^{13} \mathrm{C}$ em carbonatos ediacaranos têm sido reconhecidas em todos os continentes, não havendo similares ao longo do Fanerozoico. Estas anomalias têm sido alvo das mais diversas interpretações, especialmente quanto à resposta dos oceanos às possíveis interferências no ciclo do carbono. Neste trabalho, é apresentado um estudo quimioestratigráfico de alta resolução para seções carbonáticas da Faixa Paraguai Norte, incluindo rochas depositadas em ambientes de planície de maré, plataforma e talude. Os valores de 
$\delta^{13} \mathrm{C}$ obtidos demostram a existência de anomalias negativas (ca. - 6\%) associadas à inundação ocorrida após dois eventos glaciais distintos (formações Puga e Serra Azul). Os demais valores de $\delta^{13} \mathrm{C}$ são predominantemente negativos e evidenciam um gradiente ao longo da bacia de até $2,5 \%$. Valores anômalos de $\delta^{13} \mathrm{C}$ detectados ao longo da sucessão (- 4,5 e - 7,8\%), e não relacionados às deglaciações, foram interpretados como resultado de alteração pós-deposicional por descarboxilação. Razões ${ }^{87} \mathrm{Sr} /{ }^{86} \mathrm{Sr}$ iniciais são coerentes com a evolução esperada para os oceanos durante o Ediacarano, variando de 0.7074 (Formação Guia) a 0.7087 (Formação Serra Azul).

\section{INTRODUÇÃO}

A quimioestratigrafia isotópica de C e Sr é amplamente utilizada em seções neoproterozoicas como ferramenta na correlação estratigráfica e como indicador de eventos paleoambientais, paleoclimáticos e tectônicos. Dentro do conhecimento atual sobre o ciclo do carbono, o carbono inorgânico é convertido em carbono orgânico através de diversas trajetórias enzimáticas, sendo a fotossíntese a mais importante volumetricamente e a metanogênese a de maior poder de fracionamento (Newton \& Bottrell, 2007). Nos oceanos, a mineralização do carbonato ocorre por fotossíntese na superfície, considerada homogênea, adquirindo a composição isotópica do carbono inorgânico dissolvido (DIC: Dissolved Inorganic Carbon). Em relação à composição isotópica da matéria orgânica (MO), esta varia amplamente conforme os processos biológicos atuantes na coluna d'água e no substrato.

Durante a cristalização primária do carbonato, o $\mathrm{Sr}$ é admitido no retículo cristalino por sua afinidade com o $\mathrm{Ca}$, de forma que a composição isotópica do $\mathrm{Sr}$ marinho seja registrada. A composição isotópica de $\mathrm{Sr}$ no oceano depende das taxas de entrada de fluídos mantélicos, pouco radiogênicos, e de rios contendo $\mathrm{Sr}$ de rochas previamente intemperisadas, mais radiogênico (Banner, 2004). Em linhas gerais, as razões isotópicas de $\mathrm{Sr}$ em carbonatos podem ser utilizadas como indicador de eventos intempéricos expressivos, devido à sua residência na água do mar (ca. $4 \mathrm{Ma}$ ) ser maior que a homogeneização interoceânica (ca. 1500 anos; Broecker \& Peng, 1982; Elderfield \& Greaves, 1982). Altas razões isotópicas de Sr podem estar associadas a 
orogêneses (Derry et al., 1992; Kaufman et al., 1993) e deglaciações, enquanto que baixas razões isotópicas podem estar relacionadas à quebra de continentes (Veizer et al., 1983; Asmeron et al., 1991).

As variações de grande amplitude nos isótopos de C encontradas no Ediacarano, quando comparadas ao registro fanerozoico, sugerem consideráveis perturbações no ciclo do carbono (Kaufman \& Knoll, 1995). Na tentativa de explicar tais variações, em especial àquelas fortemente negativas ao longo do Ediacarano, diversas hipóteses vêm sendo propostas. Dentre elas, um evento de anoxia nos oceanos (Grotzinger \& Knoll, 1995), a inibição de organismos fotossintetizantes por uma glaciação global (Hoffman et al., 1998), a desestabilização de hidrato de metano de grandes proporções (Kennedy et al., 2001), a oxidação de um expressivo reservatório de carbono orgânico (Fike et al., 2006) e a existência de um oceano estratificado (Ader et al., 2009; Li et al., 2010).

Na Faixa Paraguai, o Grupo Araras é considerado uma plataforma carbonática instalada após a Glaciação Marinoana (Nogueira et al., 2003; Alvarenga et al., 2004), que foi afetada por um segundo evento glacial (Formação Serra Azul; Figueiredo et al., 2008) e posteriormente pelo Ciclo Brasiliano de orogêneses (Meert \& Van der Voo, 1997). Trabalhos anteriores mostraram uma forte anomalia negativa de $\delta^{13} \mathrm{C}$ na base do Grupo Araras, existindo um maior número de dados no domínio cratônico da Faixa Paraguai, onde se encontram os dolomitos de capa (Nogueira et al., 2003; Alvarenga et al., 2004; Font et al., 2006). Para o topo da sucessão, as curvas isotópicas disponíveis na literatura possuem baixa resolução e diferem quanto aos valores de $\delta^{13} \mathrm{C}$. Este trabalho apresenta o primeiro estudo quimioestratigráfico dos carbonatos encontrados na Formação Serra Azul, que contém uma segunda anomalia negativa de carbono registrada na Faixa Paraguai, bem como uma quimioestratigrafia isotópica de $\mathrm{C}$, $\mathrm{O}$ e $\mathrm{Sr}$ de alta resolução em seções plataformais e bacinais do Grupo Araras.

\section{DADOS SEDIMENTOLÓGICOS}

As rochas sedimentares da bacia precursora da Faixa Paraguai Norte foram depositadas na margem sudeste do Craton Amazônico (Figura 1), desenvolvendo uma 
plataforma composta por uma sucessão de diamictitos (Formação Puga), carbonatos (Grupo Araras) e diamictitos, arenitos e pelitos (Grupo Alto Paraguai).

A Formação Puga é composta predominantemente por diamictitos contendo clastos polimíticos facetados e estriados, e arenitos e pelitos subordinados. As rochas desta formação são interpretadas como de ambiente glácio-marinho e foram correlacionadas com a Glaciação Marinoana, por quimioestratigrafia isotópica dos carbonatos que a recobrem (Nogueira et al., 2003; Alvarenga et al., 2004).

O Grupo Araras é composto por uma espessa sucessão de carbonatos (ca. $1000 \mathrm{~m}$ ), desenvolvida numa margem passiva. Este grupo foi dividido por Nogueira \& Riccomini (2006) em quatro formações. Na base, se encontram os dolomitos de capa róseos da Formação Mirassol d'Oeste (ca. $30 \mathrm{~m}$ ), caracterizado por estromatólitos, tubestones, mega ripples e leques de pseudomorfos de aragonita. Recobrindo estes dolomitos se encontra a Formação Guia (ca. 250 m), composta de calcário laminado, marga e brecha, depositada em ambiente de plataforma profunda e talude. Acima desta formação, Nogueira \& Riccomini (2006) identificaram a Formação Serra do Quilombo, caracterizada por brechas cimentadas por calcita, embora a mesma não tenha sido individualizada na área de estudo. Por fim, ocorrem os dolomitos da Formação Nobres (até $800 \mathrm{~m}$ ), contendo uma ampla variedade de fácies de plataforma rasa à planície de maré.

A deposição desta plataforma carbonática é interrompida pelos diamictitos da Formação Serra Azul (Figueiredo et al., 2008), base do Grupo Alto Paraguai, considerados de ambiente glácio-marinho. Após o nível de diamictitos, ocorre a deposição de pelitos vermelhos laminados, lentes carbonáticas esparsas e pelitos com intercalação de finas camadas de arenito contendo laminações truncadas por onda, com espessamento e aumento da freqüência para o topo. O restante do Grupo Alto Paraguai é composto por arenitos e pelitos subordinados de ambiente de maré da Formação Raizama, arenitos e pelitos de ambiente litorâneo da Formação Sepotuba (Silva Júnior et al., 2007) e pelitos com arenitos subordinados de ambiente tipo molassa da Formação Diamantino (Almeida, 1964). 


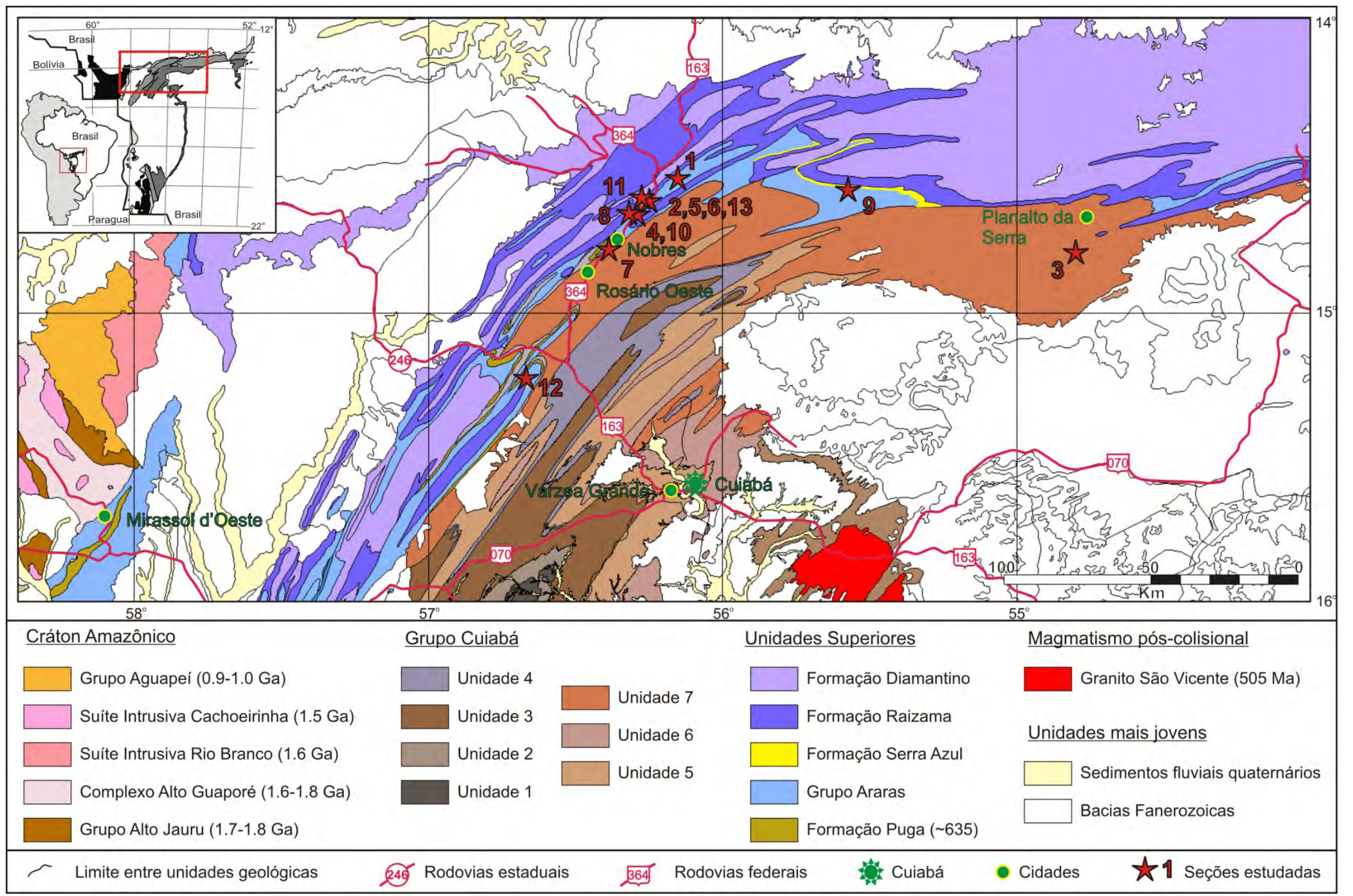

Figura 1: Mapa geológico da Faixa Paraguai (modificado de Schobenhaus et al., 2003), com a localização das seções estudadas. 


\section{PROCEDIMENTOS ANALÍTICOS}

As amostras estudadas foram coletadas em 8 seções estratigráficas, com espaçamento de $10 \mathrm{~cm}$ a $10 \mathrm{~m}$, de acordo com as condições de trabalho em campo. Estas seções foram descritas em 3 perfis de superfície, 3 cavas de mineração e 2 furos de sondagem.

As amostras coletadas foram serradas e polidas ou utilizadas na confecção de seções delgadas. As fatias polidas foram avaliadas sob lupa binocular, enquanto que as seções delgadas sob microscópio petrográfico, para seleção das amostras não alteradas para o estudo quimioestratigráfico, de acordo com os critérios de Kaufman \& Knoll (1995). Além disso, foram selecionadas para análise isotópica de $\mathrm{Sr}$ apenas as amostras com mais de $350 \mathrm{ppm}$ de Sr e que obedeceram os critérios de Denison et al. (1994) para retenção das razões originais da água do mar após a diagênese ( $\mathrm{Sr} / \mathrm{Mn}>2$ e Fe $<0,3 \%$ ). As razões ${ }^{87} \mathrm{Sr} /{ }^{86} \mathrm{Sr}$ medidas foram recalculadas para a razão inicial ( $\mathrm{t}=$ $600 \mathrm{Ma})$ com base nos teores de $\mathrm{Sr}$ e Rb.

Como estudo comparativo, quatro amostras provenientes de deslizamento intraestratal e/ou contendo um enxame de venulações foram selecionadas com o objetivo de identificar e entender as alterações isotópicas do $C$ nas amostras afetadas por fluídos tectônicos. Além da presença destes elementos de alteração, um segundo critério de seleção foi o conteúdo de $\mathrm{MO}$, sendo dois calcários negros laminados, ricos em MO, da Formação Guia e dois calcários claros, pobres em MO, incluindo uma brecha da Formação Guia e um calcário puro com pseudomorfos de aragonita da Formação Serra Azul.

As amostras foram coletadas por microdrilling com auxílio de micro-brocas Carbide ${ }^{\circledR}$. Cerca de $100 \mu \mathrm{g}$ foram destinados às analises isotópicas de $\mathrm{C}$ e $\mathrm{O}$, em procedimento on-line utilizando uma bandeja robótica Gas Bench II, para ataque com $\mathrm{H}_{3} \mathrm{PO}_{4}$, acoplada ao espectrômetro de massas Delta ${ }^{\mathrm{PLUS}}$ Advantage. As razões isotópicas de $\mathrm{C}$ e $\mathrm{O}$ obtidas foram apresentadas como $\delta^{13} \mathrm{C}$ e $\delta^{18} \mathrm{O}$, em per mil, com base no padrão Vienna Pee Dee Belemnite, cujos respectivos erros analíticos são de $0,05 \%$ e $0,07 \%$.

Para a análise isotópica de Sr, cerca de $100 \mathrm{mg}$ de amostra foi lixiviada com 2 $\mathrm{ml}$ de $\mathrm{HCl}$ 0,1 M, por uma hora, para obtenção do primeiro lixiviado, que foi descartado. 
Ao resíduo lavado e seco foram adicionados $2 \mathrm{ml}$ de $\mathrm{HCl} 1 \mathrm{M}$, que reagiu por $30 \mathrm{~min}$, para obtenção do segundo lixiviado, no qual a análise foi realizada. O Sr foi purificado pela técnica de troca iônica, usando resina $\mathrm{Sr}$ Spec. As razões isotópicas foram determinadas no espectrômetro de massas Finnigan MAT 262. A razão ${ }^{87} \mathrm{Sr} /{ }^{86} \mathrm{Sr}$ do padrão NBS é 0,710240 $\pm 0,00008$. O branco analítico do laboratório é de ca. 4 ng. As razões ${ }^{87} \mathrm{Sr} /{ }^{86} \mathrm{Sr}$ apresentadas neste trabalho são razões iniciais recalculadas (usando $\mathrm{t}$ $=600 \mathrm{Ma}$ ) com base nos teores de Rb e Sr determinados nos carbonatos.

\section{RESULTADOS}

Os resultados das análises geoquímicas realizadas em 115 amostras de carbonatos da Faixa Paraguai estão apresentados na Tabela 1. As amostras com razão $\mathrm{Mg} / \mathrm{Ca}$ acima de 0,5 (dolomitos) mostraram os menores teores de $\mathrm{Sr}$ (< 118 ppm), enquanto que as amostras com menores razões de Mg/Ca mostraram teores de Sr variando entre 157 e 5.452 ppm. Os carbonatos pós-glaciais mostraram-se predominantemente mais enriquecidos em Mn e Fe, sendo que os da Formação Guia (dolomitos da base) contem teores de Mn entre 0,01 e 0,018\% e de Fe entre 0,24 e 0,92\% e os da Formação Serra Azul (calcários) possuem teores de Mn entre 0,01 a 0,020\% e Fe entre 0,11 a 0,27\%. O restante dos carbonatos mostraram teores variáveis de $\mathrm{Mn}$ inferiores a 0,25\%, com predomínio de valores abaixo de 0,009\%, e de Fe entre 0,007 a 0,55\%, com predomínio de valores inferiores a 0,09\%.

Os resultados das análises isotópicas de C, O e Sr obtidos para os carbonatos da Faixa Paraguai são apresentados na Tabela 2 e estão representados estratigraficamente na Figura 2. Os valores de $\delta^{13} \mathrm{C}$ obtidos são predominantemente negativos, ocorrendo valores positivos no topo da Formação Nobres (Seção 0, Figura 2). Os valores de $\delta^{13} \mathrm{C}$ da Formação Guia iniciam em torno de - 5\% e desenvolvem uma trajetória positiva até valores próximos de 0\% (seções 2 e 3, Figura 2), com valores de $\delta^{18} \mathrm{O}$ entre $-3 \mathrm{e}-10 \%$. A partir daí, os valores de $\delta^{13} \mathrm{C}$ assumem uma tendência negativa até - 3\% (seções 0 e 4 , Figura 2) e $\delta^{18} \mathrm{O}$ ao redor de - 8\%, para os ritmitos, folhelhos e brechas do topo da Formação Guia.

Em fácies sedimentares semelhantes à seção anterior, porém dolomitizadas e acima dos calcários da Formação Guia (base da Formação Nobres?), estes valores de 
Tabela 1. Resultados da análise química por FRX de elementos maiores e traços para os carbonatos estudados.

\begin{tabular}{|c|c|c|c|c|c|c|c|c|c|c|c|c|c|c|c|c|}
\hline m & Amostra & $\begin{array}{c}\mathrm{Si} \\
(\%)\end{array}$ & $\begin{array}{c}\text { Al } \\
\text { (\%) }\end{array}$ & $\begin{array}{l}\text { Mn } \\
(\%)\end{array}$ & Mg (\%) & $\begin{array}{l}\mathrm{Ca} \\
(\%)\end{array}$ & $\begin{array}{l}\mathrm{Na} \\
(\%)\end{array}$ & $\begin{array}{c}K \\
(\%)\end{array}$ & $\begin{array}{c}\mathrm{Ti} \\
(\%)\end{array}$ & P (\%) & $\begin{array}{l}\mathrm{Fe} \\
(\%) \\
\end{array}$ & $\begin{array}{c}\mathrm{Rb} \\
(\mathrm{ppm})\end{array}$ & $\begin{array}{c}\mathrm{Sr} \\
(\mathrm{ppm})\end{array}$ & $\mathrm{Sr} / \mathrm{Ca}$ & $\mathrm{Rb} / \mathrm{Sr}$ & Sr/Mn \\
\hline 3.5 & FS119-4 & 6.160 & 0.950 & 0.060 & 6.6 & 24.2 & 0.12 & 0.86 & 0.050 & 0.020 & 0.71 & 24 & 208 & 0.0009 & 0.1154 & 0.3 \\
\hline 4.5 & FS119-5 & 18.750 & 4.850 & 0.100 & 5.1 & 9.7 & 0.05 & 4.02 & 0.260 & 0.090 & 2.22 & 118 & 134 & 0.0014 & 0.8797 & 0.1 \\
\hline 5.5 & FS119-6 & 0.900 & 0.150 & 0.030 & 0.3 & 38.1 & 0.02 & 0.17 & 0.010 & 0.020 & 0.45 & 9 & 446 & 0.0012 & 0.0210 & 1.5 \\
\hline 8.5 & FS119-7 & 1.820 & 0.280 & 0.020 & 0.3 & 37.5 & 0.47 & 0.28 & 0.010 & 0.010 & 0.08 & 8 & 416 & 0.0011 & 0.0197 & 2.1 \\
\hline 11.0 & FS119-8 & 1.980 & 0.250 & 0.020 & 0.5 & 37.1 & 0.02 & 0.31 & 0.010 & 0.010 & 0.08 & 10 & 383 & 0.0010 & 0.0264 & 1.9 \\
\hline 12.5 & FS119-9 & 0.350 & 0.040 & 0.010 & 0.2 & 39.2 & - & 0.09 & 0.010 & 0.030 & 0.14 & 5 & 633 & 0.0016 & 0.0085 & 6.3 \\
\hline 15.5 & FS119-10 & 0.520 & 0.080 & 0.020 & 0.3 & 38.9 & 0.02 & 0.13 & 0.010 & 0.020 & 0.11 & 6 & 644 & 0.0017 & 0.0088 & 3.2 \\
\hline 17.5 & FS119-11 & 2.240 & 0.390 & 0.010 & 1.7 & 35.4 & 0.08 & 0.30 & 0.020 & 0.020 & 0.14 & 14 & 667 & 0.0019 & 0.0210 & 6.7 \\
\hline 20.5 & FS119-12 & 1.730 & 0.310 & 0.010 & 1.0 & 36.6 & 0.34 & 0.27 & 0.030 & 0.030 & 0.16 & 10 & 683 & 0.0019 & 0.0148 & 6.8 \\
\hline 21.5 & FS119-13 & 1.230 & 0.240 & 0.010 & 0.5 & 37.9 & 0.05 & 0.17 & 0.010 & 0.020 & 0.09 & 8 & 1641 & 0.0043 & 0.0048 & 16.4 \\
\hline 22.5 & FS119-14 & 3.500 & 0.640 & 0.020 & 2.0 & 33.0 & 0.04 & 0.50 & 0.040 & 0.030 & 0.28 & 20 & 823 & 0.0025 & 0.0238 & 4.1 \\
\hline 23.5 & FS119-15 & 3.170 & 0.650 & 0.020 & 0.8 & 35.0 & 0.03 & 0.52 & 0.040 & 0.030 & 0.31 & 19 & 967 & 0.0028 & 0.0200 & 4.8 \\
\hline 24.5 & FS119-16 & 0.650 & 0.100 & 0.010 & 0.3 & 38.7 & - & 0.12 & 0.010 & 0.010 & 0.22 & 8 & 690 & 0.0018 & 0.0109 & 6.9 \\
\hline 26.5 & FS119-18 & 0.650 & 0.120 & 0.010 & 0.5 & 38.7 & - & 0.12 & 0.010 & 0.010 & 0.27 & 8 & 883 & 0.0023 & 0.0088 & 8.8 \\
\hline 27.5 & FS119-19 & 2.490 & 0.560 & 0.010 & 0.9 & 35.7 & 0.04 & 0.41 & 0.020 & 0.020 & 0.29 & 16 & 750 & 0.0021 & 0.0214 & 7.5 \\
\hline 28.5 & FS119-20 & 3.050 & 0.660 & 0.020 & 0.9 & 35.0 & 0.02 & 0.61 & 0.040 & 0.030 & 0.31 & 17 & 616 & 0.0018 & 0.0276 & 3.1 \\
\hline 29.5 & FS119-21 & 2.130 & 0.480 & 0.020 & 0.8 & 36.5 & 0.02 & 0.39 & 0.020 & 0.020 & 0.22 & 14 & 1025 & 0.0028 & 0.0135 & 5.1 \\
\hline 30.5 & FS119-22 & 2.830 & 0.620 & 0.030 & 0.6 & 35.6 & 0.02 & 0.48 & 0.030 & 0.020 & 0.26 & 19 & 466 & 0.0013 & 0.0407 & 1.6 \\
\hline 31.5 & FS119-23 & 14.340 & 3.220 & 0.050 & 5.5 & 16.0 & 0.05 & 2.44 & 0.160 & 0.040 & 1.53 & 71 & 331 & 0.0021 & 0.2150 & 0.7 \\
\hline 53.0 & PS01 & 5.119 & 0.508 & 0.013 & 11.5 & 19.2 & - & 0.523 & 0.031 & 0.017 & 0.37 & 15 & 48 & 0.0003 & 0.3132 & 0.4 \\
\hline 52.0 & PS02 & 11.169 & 0.403 & 0.010 & 9.8 & 16.5 & - & 0.374 & 0.028 & 0.017 & 0.25 & 13 & 56 & 0.0003 & 0.2343 & 0.6 \\
\hline 51.0 & PS03 & 9.360 & 1.885 & 0.015 & 9.7 & 15.9 & 0.11 & 1.320 & 0.109 & 0.038 & 0.92 & 40 & 53 & 0.0003 & 0.7463 & 0.4 \\
\hline 50.0 & PSO4 & 7.625 & 1.467 & 0.013 & 10.4 & 17.1 & - & 1.088 & 0.077 & 0.031 & 0.76 & 33 & 56 & 0.0003 & 0.5834 & 0.4 \\
\hline 49.0 & PS05 & 5.059 & 1.133 & 0.014 & 11.5 & 18.7 & - & 1.054 & 0.065 & 0.026 & 0.43 & 29 & 90 & 0.0005 & 0.3189 & 0.6 \\
\hline 41.0 & PS06 & 5.807 & 0.551 & 0.010 & 11.3 & 18.9 & 0.10 & 0.448 & 0.036 & 0.021 & 0.24 & 15 & 56 & 0.0003 & 0.2709 & 0.6 \\
\hline 26.0 & PS08 & 4.474 & 0.546 & 0.018 & 11.6 & 19.4 & - & 0.548 & 0.041 & 0.013 & 0.36 & 16 & 40 & 0.0002 & 0.4044 & 0.2 \\
\hline 19.0 & PSO9 & 6.812 & 0.704 & 0.015 & 10.9 & 18.2 & - & 0.714 & 0.049 & 0.015 & 0.27 & 19 & 50 & 0.0003 & 0.3768 & 0.3 \\
\hline 8.0 & PS11 & 5.783 & 0.614 & 0.020 & 6.4 & 25.1 & - & 0.606 & 0.043 & 0.015 & 0.34 & 15 & 177 & 0.0007 & 0.0869 & 0.9 \\
\hline 17.2 & SA43C & 1.057 & 0.614 & 0.008 & 1.0 & 37.2 & - & 0.116 & 0.010 & 0.009 & 0.18 & 6 & 572 & 0.0015 & 0.0103 & 7.4 \\
\hline
\end{tabular}




\begin{tabular}{|c|c|c|c|c|c|c|c|c|c|c|c|c|c|c|c|c|}
\hline $\mathbf{m}$ & Amostra & $\begin{array}{c}\mathrm{Si} \\
(\%)\end{array}$ & $\begin{array}{c}\text { Al } \\
(\%)\end{array}$ & $\begin{array}{l}\mathrm{Mn} \\
(\%)\end{array}$ & $\mathrm{Mg}(\%)$ & $\begin{array}{l}\mathrm{Ca} \\
(\%)\end{array}$ & $\begin{array}{l}\mathrm{Na} \\
(\%)\end{array}$ & $\begin{array}{c}K \\
(\%)\end{array}$ & $\begin{array}{c}\mathrm{Ti} \\
(\%) \\
\end{array}$ & P (\%) & $\begin{array}{l}\mathrm{Fe} \\
(\%)\end{array}$ & $\begin{array}{c}\mathbf{R b} \\
(\mathbf{p p m})\end{array}$ & $\begin{array}{c}\mathrm{Sr} \\
(\mathrm{ppm})\end{array}$ & Sr/Ca & $\mathrm{Rb} / \mathrm{Sr}$ & Sr/Mn \\
\hline 24.9 & SA43D & 2.216 & 0.196 & 0.025 & 3.4 & 32.4 & - & 0.232 & 0.014 & - & 0.16 & 11 & 158 & 0.0005 & 0.0676 & 0.6 \\
\hline 50.9 & SA43F & 2.576 & 0.270 & 0.008 & 1.7 & 34.4 & - & 0.274 & 0.016 & - & 0.14 & 11 & 515 & 0.0015 & 0.0222 & 6.7 \\
\hline 66.3 & SA43G & 0.065 & 0.011 & 0.005 & 0.2 & 39.2 & 0.02 & 0.033 & 0.004 & - & 0.01 & 3 & 528 & 0.0013 & 0.0059 & 9.7 \\
\hline 75.5 & $\mathrm{SA} 43 \mathrm{H}$ & 0.257 & - & 0.005 & 0.2 & 38.9 & - & 0.042 & 0.005 & - & 0.04 & 5 & 719 & 0.0018 & 0.0071 & 15.5 \\
\hline 114.9 & SA44W & 0.678 & 0.005 & 0.002 & 0.1 & 38.9 & - & 0.033 & - & - & 0.11 & 1 & 3291 & 0.0085 & 0.0002 & 212.5 \\
\hline 124.1 & SA44T & 4.404 & 0.821 & 0.009 & 2.8 & 31.1 & 0.10 & 0.623 & 0.044 & 0.034 & 0.41 & 19 & 1188 & 0.0038 & 0.0162 & 13.9 \\
\hline 133.3 & SA44Q & 3.782 & 0.630 & 0.007 & 1.9 & 33.0 & 0.07 & 0.490 & 0.033 & 0.028 & 0.29 & 17 & 1346 & 0.0041 & 0.0123 & 19.3 \\
\hline 142.5 & SA44N & 5.040 & 1.335 & - & 6.3 & 23.6 & 0.05 & 0.955 & 0.069 & 0.036 & 0.62 & 32 & 884 & 0.0037 & 0.0367 & - \\
\hline 151.7 & SA44K & 1.725 & 0.111 & 0.003 & 1.5 & 36.1 & - & 0.091 & 0.011 & 0.015 & 0.08 & 4 & 733 & 0.0020 & 0.0060 & 23.7 \\
\hline 163.9 & SA44D & 7.504 & 1.123 & 0.013 & 6.3 & 23.2 & 0.07 & 0.789 & 0.065 & 0.017 & 0.55 & 29 & 1032 & 0.0045 & 0.0285 & 7.8 \\
\hline 170.1 & SA44F & 0.337 & - & 0.003 & 0.3 & 38.9 & - & - & 0.004 & - & 0.01 & 2 & 1294 & 0.0033 & 0.0015 & 41.8 \\
\hline 179.3 & SA44I & 3.810 & 0.588 & - & 4.3 & 30.0 & - & 0.482 & 0.037 & 0.025 & 0.36 & 16 & 595 & 0.0020 & 0.0274 & - \\
\hline 185.4 & SA45A & 5.587 & 1.022 & 0.009 & 2.4 & 29.7 & 0.11 & 0.731 & 0.064 & 0.040 & 0.54 & 28 & 483 & 0.0016 & 0.0580 & 5.7 \\
\hline 197.6 & SA45Z & 0.005 & - & - & 0.2 & 39.7 & - & - & - & - & 0.08 & 2 & 696 & 0.0018 & 0.0026 & - \\
\hline 206.8 & SA45V & 4.428 & 0.874 & 0.008 & 2.2 & 31.7 & 0.10 & 0.731 & 0.044 & 0.030 & 0.43 & 23 & 886 & 0.0028 & 0.0264 & 11.4 \\
\hline 216.0 & SA45S & 0.023 & - & 0.003 & 0.3 & 39.1 & 0.02 & 0.008 & 0.003 & - & 0.01 & 3 & 482 & 0.0012 & 0.0058 & 15.6 \\
\hline 225.2 & SA45P & 5.241 & 0.741 & 0.022 & 5.1 & 27.9 & 0.06 & 0.440 & 0.040 & 0.024 & 0.37 & 18 & 902 & 0.0032 & 0.0199 & 4.2 \\
\hline 234.4 & SA45M & 0.907 & 0.143 & 0.002 & 0.4 & 37.8 & - & 0.174 & 0.013 & 0.041 & 0.10 & 4 & 2094 & 0.0055 & 0.0021 & 135.2 \\
\hline 243.6 & SA45J & 1.183 & 0.127 & 0.004 & 0.7 & 37.7 & 0.04 & 0.075 & 0.010 & 0.019 & 0.07 & 5 & 902 & 0.0024 & 0.0057 & 23.3 \\
\hline 252.8 & SA45G & 1.674 & 0.286 & 0.004 & 1.4 & 35.8 & 0.04 & 0.257 & 0.019 & 0.028 & 0.15 & 9 & 1013 & 0.0028 & 0.0084 & 26.2 \\
\hline 258.9 & SA45E & 0.351 & 0.053 & 0.002 & 1.6 & 36.7 & - & 0.066 & 0.006 & - & 0.05 & 5 & 661 & 0.0018 & 0.0075 & 28.4 \\
\hline 306.9 & SA46 & 1.370 & 0.185 & 0.004 & 1.1 & 36.6 & 0.04 & 0.216 & 0.012 & 0.024 & 0.10 & 7 & 798 & 0.0022 & 0.0088 & 20.6 \\
\hline 314.0 & SA47 & 1.001 & - & 0.003 & 1.5 & 37.4 & - & - & - & 0.024 & 0.07 & 4 & 440 & 0.0012 & 0.0086 & 14.2 \\
\hline 18.0 & FS 184-3 & 1.370 & 0.210 & 0.010 & 13.0 & 21.0 & - & 0.21 & 0.020 & 0.010 & 0.07 & 6 & 82 & 0.0004 & 0.0680 & 0.8 \\
\hline 29.2 & FS 184-8 & 0.260 & 0.010 & 0.010 & 13.5 & 21.8 & - & 0.02 & - & - & 0.06 & 1 & 66 & 0.0003 & 0.0152 & 0.7 \\
\hline 34.8 & FS $184-9$ & 0.190 & 0.010 & 0.010 & 13.4 & 21.7 & - & 0.02 & - & 0.010 & 0.06 & 1 & 63 & 0.0003 & 0.0175 & 0.6 \\
\hline 42.5 & FS $184-13$ & 0.230 & 0.010 & 0.010 & 13.3 & 21.8 & - & 0.02 & - & - & 0.08 & 1 & 69 & 0.0003 & 0.0188 & 0.7 \\
\hline 50.8 & FS $184-17 a$ & 4.110 & 0.860 & 0.010 & 12.0 & 19.1 & - & 0.77 & 0.040 & 0.020 & 0.38 & 17 & 63 & 0.0003 & 0.2758 & 0.6 \\
\hline 50.8 & FS 184-17b & 4.110 & 0.830 & 0.010 & 11.9 & 19.1 & - & 0.77 & 0.050 & 0.020 & 0.36 & 17 & 63 & 0.0003 & 0.2758 & 0.6 \\
\hline 51.9 & FS $184-18$ & 2.160 & 0.400 & 0.010 & 12.4 & 20.4 & - & 0.41 & 0.020 & 0.010 & 0.31 & 11 & 91 & 0.0004 & 0.1199 & 0.9 \\
\hline 54.2 & FS $184-21$ & 0.020 & 0.010 & 0.010 & 13.4 & 21.9 & - & 0.01 & 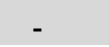 & 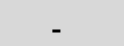 & 0.07 & 1 & 57 & 0.0003 & 0.0088 & 0.6 \\
\hline 55.4 & FS 184-22 & 0.360 & 0.010 & 0.010 & 13.3 & 21.7 & - & 0.01 & - & - & 0.07 & 0 & 64 & 0.0003 & 0.0031 & 0.6 \\
\hline
\end{tabular}




\begin{tabular}{|c|c|c|c|c|c|c|c|c|c|c|c|c|c|c|c|c|c|}
\hline & m & Amostra & $\begin{array}{c}\mathrm{Si} \\
(\%)\end{array}$ & $\begin{array}{c}\text { Al } \\
(\%)\end{array}$ & $\begin{array}{l}\text { Mn } \\
\text { (\%) }\end{array}$ & Mg (\%) & $\begin{array}{l}\mathrm{Ca} \\
(\%)\end{array}$ & $\begin{array}{l}\mathrm{Na} \\
(\%)\end{array}$ & $\begin{array}{c}K \\
(\%) \\
\end{array}$ & $\begin{array}{c}\mathrm{Ti} \\
(\%)\end{array}$ & P (\%) & $\begin{array}{l}\mathrm{Fe} \\
(\%)\end{array}$ & $\begin{array}{c}\mathbf{R b} \\
(\mathrm{ppm})\end{array}$ & $\begin{array}{c}\mathrm{Sr} \\
(\mathrm{ppm})\end{array}$ & $\mathrm{Sr} / \mathrm{Ca}$ & $\mathrm{Rb} / \mathrm{Sr}$ & Sr/Mn \\
\hline \multirow{24}{*}{ 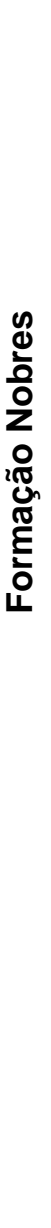 } & 59.4 & FS $184-25$ & 1.250 & 0.150 & 0.010 & 12.8 & 21.2 & - & 0.18 & 0.010 & 0.010 & 0.11 & 6 & 85 & 0.0004 & 0.0686 & 0.8 \\
\hline & 321.0 & SA48 & 2.001 & - & 0.003 & 12.2 & 23.2 & - & - & - & 0.010 & 0.06 & 3 & 70 & 0.0003 & 0.0391 & 2.3 \\
\hline & 328.1 & SA49 & 3.001 & - & 0.004 & 0.8 & 35.5 & - & - & - & 0.027 & 0.12 & 5 & 932 & 0.0026 & 0.0050 & 24.1 \\
\hline & 335.2 & SA50B & 1.501 & 0.254 & 0.003 & 3.0 & 34.1 & 0.06 & 0.191 & 0.015 & 0.034 & 0.11 & 6 & 1262 & 0.0037 & 0.0044 & 40.7 \\
\hline & 342.2 & SA51 & 4.001 & - & 0.003 & 12.5 & 22.3 & - & - & - & 0.016 & 0.08 & 2 & 45 & 0.0002 & 0.0386 & 1.5 \\
\hline & 349.3 & SA52 & 5.001 & - & 0.002 & 3.6 & 34.9 & - & - & - & 0.014 & 0.06 & 3 & 640 & 0.0018 & 0.0053 & 27.5 \\
\hline & 356.4 & SA53 & 6.001 & - & 0.002 & 12.9 & 22.5 & - & - & - & 0.011 & 0.03 & 1 & 37 & 0.0002 & 0.0372 & 1.6 \\
\hline & 363.5 & SA54 & 0.001 & - & 0.002 & 13.4 & 22.4 & - & 0.008 & 0.004 & 0.014 & 0.01 & 2 & 50 & 0.0002 & 0.0304 & 3.2 \\
\hline & 370.5 & SA55 & 7.001 & - & 0.002 & 13.3 & 22.2 & - & - & - & 0.021 & 0.02 & 1 & 63 & 0.0003 & 0.0193 & 4.1 \\
\hline & 377.6 & SA56 & 8.001 & - & 0.002 & 13.6 & 22.4 & - & - & - & - & 0.02 & 1 & 36 & 0.0002 & 0.0261 & 1.6 \\
\hline & 391.7 & SA58 & 1.622 & 0.175 & 0.003 & 13.2 & 21.2 & - & 0.166 & 0.013 & 0.022 & 0.09 & 5 & 44 & 0.0002 & 0.1107 & 1.4 \\
\hline & 405.9 & SA60 & 9.001 & - & 0.002 & 0.4 & 39.2 & - & - & - & 0.013 & 0.03 & 3 & 824 & 0.0021 & 0.0036 & 35.5 \\
\hline & 410.1 & SA61 & 10.001 & - & 0.002 & 0.8 & 38.3 & - & - & - & 0.034 & 0.06 & 4 & 629 & 0.0016 & 0.0067 & 27.1 \\
\hline & 422.8 & SA63 & 11.001 & - & 0.002 & 0.6 & 38.6 & - & - & - & 0.017 & 0.05 & 3 & 794 & 0.0021 & 0.0036 & 34.2 \\
\hline & 479.4 & SA64 & 0.238 & 0.021 & 0.003 & 0.4 & 38.5 & - & 0.050 & 0.005 & - & 0.02 & 8 & 862 & 0.0022 & 0.0091 & 27.8 \\
\hline & 486.5 & SA65 & 0.351 & 0.037 & 0.002 & 13.6 & 22.0 & - & 0.050 & 0.006 & 0.010 & 0.03 & 2 & 36 & 0.0002 & 0.0690 & 2.3 \\
\hline & 493.6 & SA66 & 12.001 & - & 0.002 & 13.3 & 22.2 & - & - & - & - & 0.03 & 2 & 39 & 0.0002 & 0.0448 & 2.5 \\
\hline & 514.8 & SA69 & 0.309 & - & 0.002 & 13.7 & 21.9 & - & - & 0.004 & - & 0.01 & 1 & 36 & 0.0002 & 0.0231 & 2.4 \\
\hline & 571.3 & SA77 & - & - & 0.002 & 13.8 & 22.0 & - & - & - & - & 0.01 & 1 & 43 & 0.0002 & 0.0161 & 1.9 \\
\hline & 642.1 & SA82 & 0.094 & - & 0.002 & 13.7 & 22.2 & - & - & 0.004 & 0.010 & 0.01 & 1 & 79 & 0.0004 & 0.0185 & 3.4 \\
\hline & 670.3 & SA84 & 13.001 & - & 0.002 & 13.2 & 22.1 & - & - & - & 0.010 & 0.05 & 2 & 32 & 0.0001 & 0.0601 & 2.1 \\
\hline & 698.6 & SA86 & 0.196 & - & 0.002 & 13.7 & 21.8 & - & - & - & - & 0.01 & 0 & 29 & 0.0001 & 0.0130 & 1.9 \\
\hline & 726.9 & SA88 & 14.001 & - & 0.002 & 12.7 & 21.0 & - & - & - & 0.019 & 0.02 & 1 & 30 & 0.0001 & 0.0352 & 1.3 \\
\hline & 755.2 & SA90 & 2.688 & - & 0.002 & 12.9 & 20.8 & - & - & 0.005 & 0.031 & 0.01 & 1 & 52 & 0.0002 & 0.0216 & 3.3 \\
\hline \multirow{5}{*}{ 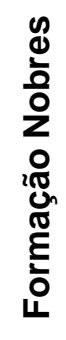 } & 866.9 & SA94 & 0.514 & 0.053 & 0.005 & 13.7 & 21.3 & - & 0.108 & 0.005 & - & 0.06 & 3 & 87 & 0.0004 & 0.0386 & 1.6 \\
\hline & 881.1 & SA95 & 15.001 & - & 0.004 & 13.2 & 21.9 & - & - & - & - & 0.06 & 2 & 62 & 0.0003 & 0.0265 & 1.6 \\
\hline & 895.2 & SA96 & 16.001 & - & 0.003 & 13.1 & 22.0 & - & - & - & - & 0.05 & 2 & 70 & 0.0003 & 0.0311 & 2.3 \\
\hline & 909.3 & SA97 & 10.590 & 1.451 & 0.009 & 9.9 & 15.6 & 0.01 & 1.594 & 0.054 & 0.017 & 0.17 & 35 & 78 & 0.0005 & 0.4562 & 0.8 \\
\hline & 951.8 & SA100 & - & - & 0.004 & 13.8 & 21.9 & - & - & - & - & 0.02 & 2 & 75 & 0.0003 & 0.0272 & 1.9 \\
\hline
\end{tabular}




\begin{tabular}{|c|c|c|c|c|c|c|c|c|c|c|c|c|c|c|c|c|c|}
\hline & m & Amostra & $\begin{array}{c}\mathrm{Si} \\
(\%)\end{array}$ & $\begin{array}{c}\mathrm{Al} \\
(\%)\end{array}$ & $\begin{array}{l}\mathrm{Mn} \\
(\%)\end{array}$ & Mg (\%) & $\begin{array}{l}\mathrm{Ca} \\
(\%)\end{array}$ & $\begin{array}{l}\mathrm{Na} \\
(\%)\end{array}$ & $\begin{array}{c}\mathrm{K} \\
(\%) \\
\end{array}$ & $\begin{array}{c}\mathrm{Ti} \\
(\%) \\
\end{array}$ & P (\%) & $\begin{array}{l}\mathrm{Fe} \\
(\%) \\
\end{array}$ & $\begin{array}{c}\mathbf{R b} \\
(\mathrm{ppm})\end{array}$ & $\begin{array}{c}\mathrm{Sr} \\
(\mathrm{ppm})\end{array}$ & Sr/Ca & $\mathrm{Rb} / \mathrm{Sr}$ & Sr/Mn \\
\hline & 965.9 & SA101 & - & - & 0.003 & 13.9 & 22.1 & - & - & - & 0.020 & 0.02 & 1 & 87 & 0.0004 & 0.0138 & 2.8 \\
\hline \multirow{18}{*}{ 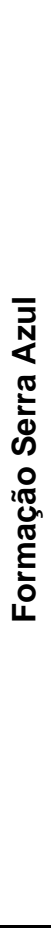 } & 1684.0 & SA19I & 0.912 & 0.207 & 0.020 & 0.3 & 37.8 & - & 0.166 & 0.016 & - & 0.20 & 9 & 548 & 0.0014 & 0.0167 & 2.7 \\
\hline & 1686.5 & SA19H & 2.179 & 0.498 & 0.014 & 0.3 & 36.7 & 0.05 & 0.349 & 0.028 & 0.008 & 0.27 & 14 & 1152 & 0.0031 & 0.0117 & 8.3 \\
\hline & 1687.7 & SA19G & 1.678 & 0.413 & 0.018 & 0.2 & 36.9 & - & 0.31 & 0.025 & - & 0.27 & 14 & 885 & 0.0024 & 0.0153 & 5.0 \\
\hline & 1689.6 & SA19F & 1.211 & 0.164 & 0.014 & 0.1 & 38.4 & - & 0.14 & 0.010 & - & 0.12 & 6 & 376 & 0.0010 & 0.0166 & 2.7 \\
\hline & 1691.0 & SA19E & 1.005 & 0.180 & 0.007 & 0.1 & 38.1 & - & 0.16 & 0.013 & - & 0.12 & 8 & 820 & 0.0022 & 0.0104 & 11.8 \\
\hline & 1692.4 & SA19D & 0.912 & 0.159 & 0.016 & 0.1 & 38.2 & 0.03 & 0.13 & 0.011 & - & 0.11 & 5 & 744 & 0.0019 & 0.0062 & 4.6 \\
\hline & 1696.4 & SA19C & 0.262 & 0.058 & 0.005 & 0.1 & 39.4 & 0.02 & 0.06 & 0.007 & - & 0.04 & 4 & 741 & 0.0019 & 0.0048 & 16.0 \\
\hline & 1697.4 & $\mathrm{~B} \times 01$ & 0.369 & - & 0.012 & 13.1 & 21.9 & 0.01 & 0.03 & 0.010 & 0.013 & 0.09 & 2 & 44 & 0.0002 & 0.0413 & 0.4 \\
\hline & 1698.4 & $\mathrm{BX} 03$ & 0.538 & - & 0.009 & 12.4 & 22.5 & 0.01 & 0.04 & 0.013 & 0.024 & 0.19 & 2 & 117 & 0.0005 & 0.0183 & 1.4 \\
\hline & 1699.4 & $\mathrm{BX} 06$ & 0.458 & - & 0.011 & 13.0 & 22.0 & - & 0.03 & 0.011 & 0.018 & 0.10 & 2 & 51 & 0.0002 & 0.0326 & 0.5 \\
\hline & 1700.4 & $B \times 09$ & 2.651 & 0.175 & 0.013 & 12.1 & 21.0 & - & 0.11 & 0.017 & 0.031 & 0.14 & 4 & 89 & 0.0004 & 0.0437 & 0.7 \\
\hline & 1701.4 & $\mathrm{BX} 11$ & 1.117 & 0.064 & 0.012 & 12.7 & 21.7 & - & 0.07 & 0.013 & 0.049 & 0.12 & 4 & 74 & 0.0003 & 0.0504 & 0.6 \\
\hline & 1702.4 & $\mathrm{BX} 13$ & 1.239 & 0.132 & 0.004 & 4.0 & 33.1 & 0.02 & 0.16 & 0.016 & 0.025 & 0.14 & 5 & 426 & 0.0013 & 0.0119 & 11.0 \\
\hline & 1704.4 & $\mathrm{BX} 16$ & 0.659 & 0.079 & 0.005 & 0.4 & 39.2 & 0.02 & 0.13 & 0.013 & 0.019 & 0.05 & 5 & 1140 & 0.0029 & 0.0048 & 24.5 \\
\hline & 1705.4 & $\mathrm{BX} 18$ & 0.893 & 0.106 & 0.003 & 1.3 & 38.0 & - & 0.11 & 0.010 & - & 0.07 & 4 & 526 & 0.0014 & 0.0074 & 17.0 \\
\hline & 1706.4 & $B \times 20$ & 0.678 & - & 0.003 & 0.4 & 38.6 & 0.02 & 0.05 & 0.007 & - & 0.06 & 2 & 5452 & 0.0141 & 0.0004 & 176.0 \\
\hline & 1707.4 & $\mathrm{~B} \times 21$ & 0.799 & 0.037 & 0.002 & 0.5 & 38.2 & 0.01 & 0.07 & 0.008 & 0.008 & 0.06 & 2 & 5017 & 0.0131 & 0.0004 & 215.9 \\
\hline & 1708.4 & $\mathrm{BX} 22$ & 1.421 & 0.286 & 0.003 & 0.8 & 37.0 & 0.015 & 0.22 & 0.020 & 0.024 & 0.17 & 3 & 4865 & 0.0131 & 0.0006 & 157.0 \\
\hline
\end{tabular}

Limites de detecção (\%): 0,001 para P; 0,002 para Mn; 0,004 para Ti; 0,005 para Si e Al; 0,006 para Mg; 0,007 para Ca e Fe; 0,008 para P; 0,015 para Na. 
$\delta^{13} \mathrm{C}$ tendem novamente para valores próximos de 0\% (seção 0 e base da seção 6 , Figura 2), passando a valores mais constantes, ao redor de $-1 \%$, nas fácies mais rasas (seção 6, Figura 2), com valores $\delta^{18} \mathrm{O}$ entre $-8 \mathrm{e}-3 \%$, predominado os valores em torno de $-6 \%$. Para o topo, a quantidade de dados é menor, sendo que as seções amostradas da Formação Nobres apresentam valores de $\delta^{13} \mathrm{C}$ dispersos, inicialmente mais positivos, entre 0 e $+2 \%$, para fácies de plataforma, e posteriormente em torno de $0 \%$, com alguns valores negativos (até - $2 \%$ ), para as fácies de planície de maré. Os valores de $\delta^{18} \mathrm{O}$ oscilam ao redor de $-4 \%$.

Acima dos diamictitos glaciais da Formação Serra Azul, encontram-se lentes calcárias que forneceram valores de $\delta^{13} \mathrm{C}$ entre -3 e $-7 \%$ e de $\delta^{18} \mathrm{O}$ de $-8 \mathrm{a}-6 \%$, para a primeira lente (seção 11; Figura 2), e valores de $\delta^{13} \mathrm{C}$ entre -1 e $1 \%$ e de $\delta^{18} \mathrm{O}$ entre -9 e $-4 \%$ para a segunda e terceira lentes (seção 12, Figura 2).

A razão ${ }^{87} \mathrm{Sr} /{ }^{86} \mathrm{Sr}$ inicial obtida para o carbonato depositado imediatamente após a Formação Puga, na seção 3 , apresenta-se radiogênica $(0,7080)$. Os carbonatos que se sucedem são inicialmente menos radiogênicos, com razões ${ }^{87} \mathrm{Sr} /{ }^{86} \mathrm{Sr}$ de 0,7074 (seções 0, 13 e 4, Figura 2), passando para carbonatos com razões mais radiogênicas para o topo, chegando a razões ${ }^{87} \mathrm{Sr} /{ }^{86} \mathrm{Sr}$ de 0,7088 nos carbonatos depositados após o segundo nível de diamictitos (seções 11 e 12, Figura 2).

\section{DISCUSSÃO}

Os resultados obtidos permitem a avaliação dos processos de alteração, bem como a identificação de valores isotópicos representativos da água do mar. A comparação dos resultados isotópicos com a variação de fácies permite identificar um gradiente isotópico ao longo da bacia. Além disso, a correlação das seções estudadas com outras ao longo da mesma bacia e de outras bacias, permite algumas inferências sobre o ambiente marinho ediacarano, como discutido abaixo. 


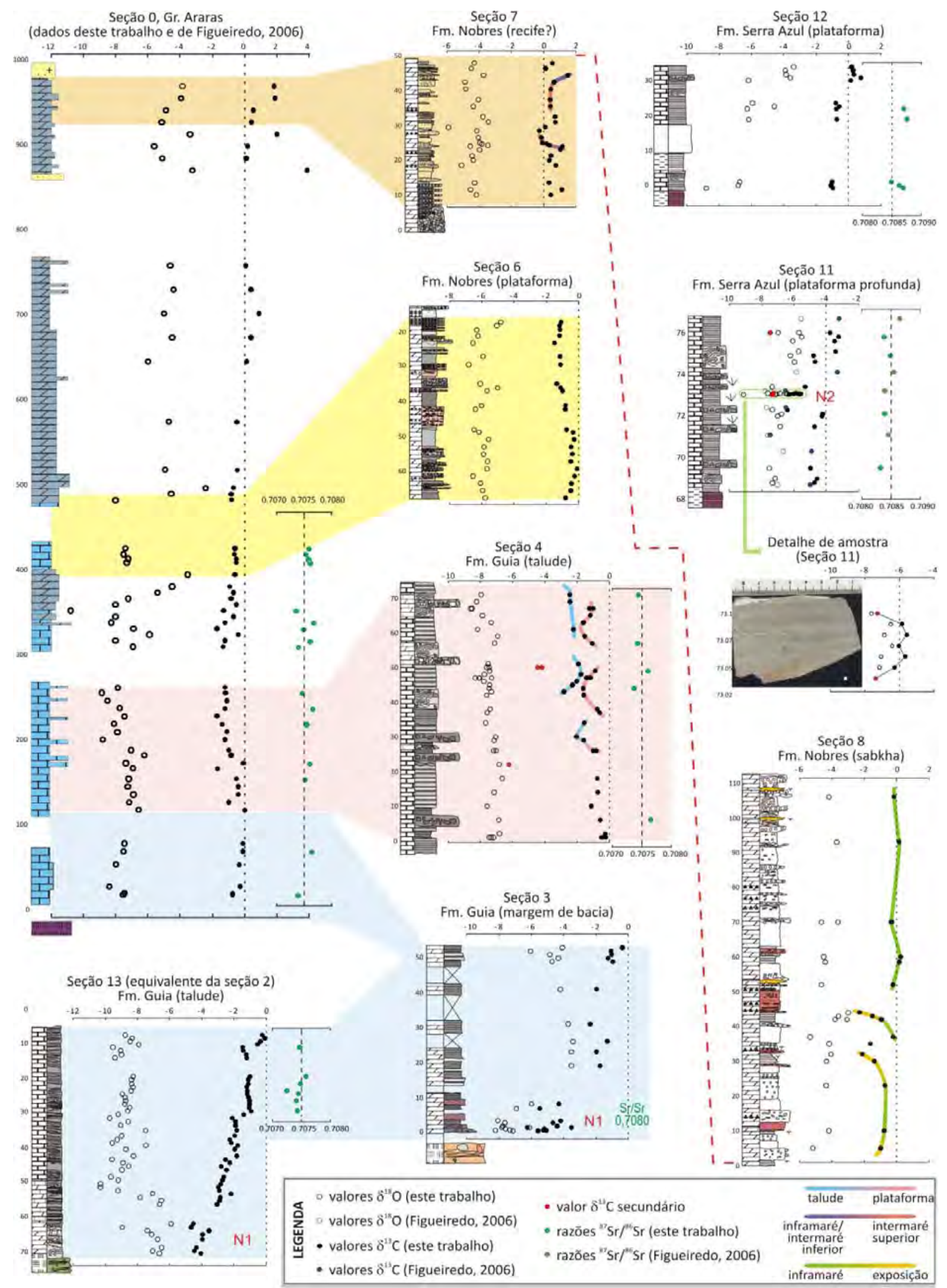

Figura 2: Curvas quimioestratigráficas de $\delta^{13} \mathrm{C}$ e $\delta^{18} \mathrm{O}$ de alta resolução para as seções estudadas das formações Guia, Nobres e Serra Azul. A correlação com a curva geral (seção 0) obtida por Figueiredo (2006) é marcada em caixas coloridas. A linha pontilhada vermelha posiciona a seção 8 e demais acima da seção 7. As linhas coloridas ligando pontos de $\delta^{13} C$ mostram indicam o ambiente sedimentar. Para legenda das litologias, recorrer à Figura 4, no Capítulo 3. 


\section{Alteração da assinatura isotópica}

Os carbonatos marinhos guardam a composição isotópica de C, O e Sr da água do mar no momento de sua deposição, porém os minerais depositados são metaestáveis, transformando-se em carbonatos estáveis fora do contato com a água do mar durante a eo-diagênese (Fairchild \& Kennedy, 2007). Assumindo-se que esta estabilização ocorra em sistema fechado, os novos carbonatos gerados guardarão as composições originais da água do mar (Jacobsen \& Kaufman, 1999). No entanto, a interação dos minerais formados com fluídos não-marinhos tendem a alterar as composições isotópicas originais, sem necessariamente alterar a textura da rocha. $O$ desafio na quimioestratigrafia isotópica está em identificar as amostras que mantiveram a composição isotópica original da água do mar após a deposição, especialmente em rochas antigas e deformadas.

Neste trabalho, foram empregados parâmetros químicos de avaliação da alteração diagenética, como a razão Sr/Mn, Sr/Ca e teores de Fe e Mn. Estes parâmetros indicam a interação da rocha com fluidos não-marinhos, como água doce ou meteórica, que costumam conter mais Mn e Fe e menos Sr que a água do mar. Além disso, durante a troca com fluídos diagenéticos, o Sr é facilmente lixiviado da estrutura do carbonato, enquanto que o Mn é facilmente incorporado (Brand \& Veizer, 1980). Para as razões ${ }^{87} \mathrm{Sr}{ }^{86} \mathrm{Sr}$, foram consideradas como inalteradas as amostras com razão $\mathrm{Mn} / \mathrm{Sr}$ inferior a 0,5 e teores de $\mathrm{Mn}$ e Fe abaixo de 0,03 e 0,3\%, respectivamente (Denison et al., 1994). Para os valores $\delta^{13} \mathrm{C}$, foram admitidas como inalteradas as amostras com razões $\mathrm{Mn} / \mathrm{Sr}$ menores que 10, pois o volume de água meteórica que facilmente alteraria as razões $\mathrm{Mn} / \mathrm{Sr}$ dificilmente altera a composição de elementos maiores, mantendo a composição isotópica de C (Kaufman \& Knoll, 1995). Apesar das amostras analisadas apresentarem teores de Mn inferiores a 0,03\%, a razão Sr/Ca mostra uma considerável perda de Sr nos termos mais dolomíticos (Figura 3), sendo que as amostras com razão Sr/Ca inferiores a 0,0010 foram consideradas como tendo suas composições de Sr alteradas pela diagênese e, portanto, inadequadas para análise isotópica de Sr.

Algumas amostras afetadas por processos tectônicos foram analisadas a fim de se obter valores de $\delta^{13} \mathrm{C}$ característicos da alteração por fluídos tectônicos. Duas amostras da Formação Guia, de calcário rico em MO, foram coletadas de pequenas 
zonas de cisalhamento geradas por deslizamento intra-estratal. Ambas as amostras mostraram maturação aparente da MO, com geração de óleo e vitrinita, provavelmente relacionada ao aumento localizado da temperatura e pressão devido ao dobramento. A amostra que apresentou geração e migração de betume possui valores de $\delta^{13} \mathrm{C}$ de $4,2 \%$ para a matriz drenada e de $-4,5 \%$ para a matriz embebida (Figura 4 ). A amostra contendo vitrinita entre as lâminas e vênulas de calcita perpendiculares ao acamamento apresentou valor de $\delta^{13} \mathrm{C}$ de $-6,2 \%$.

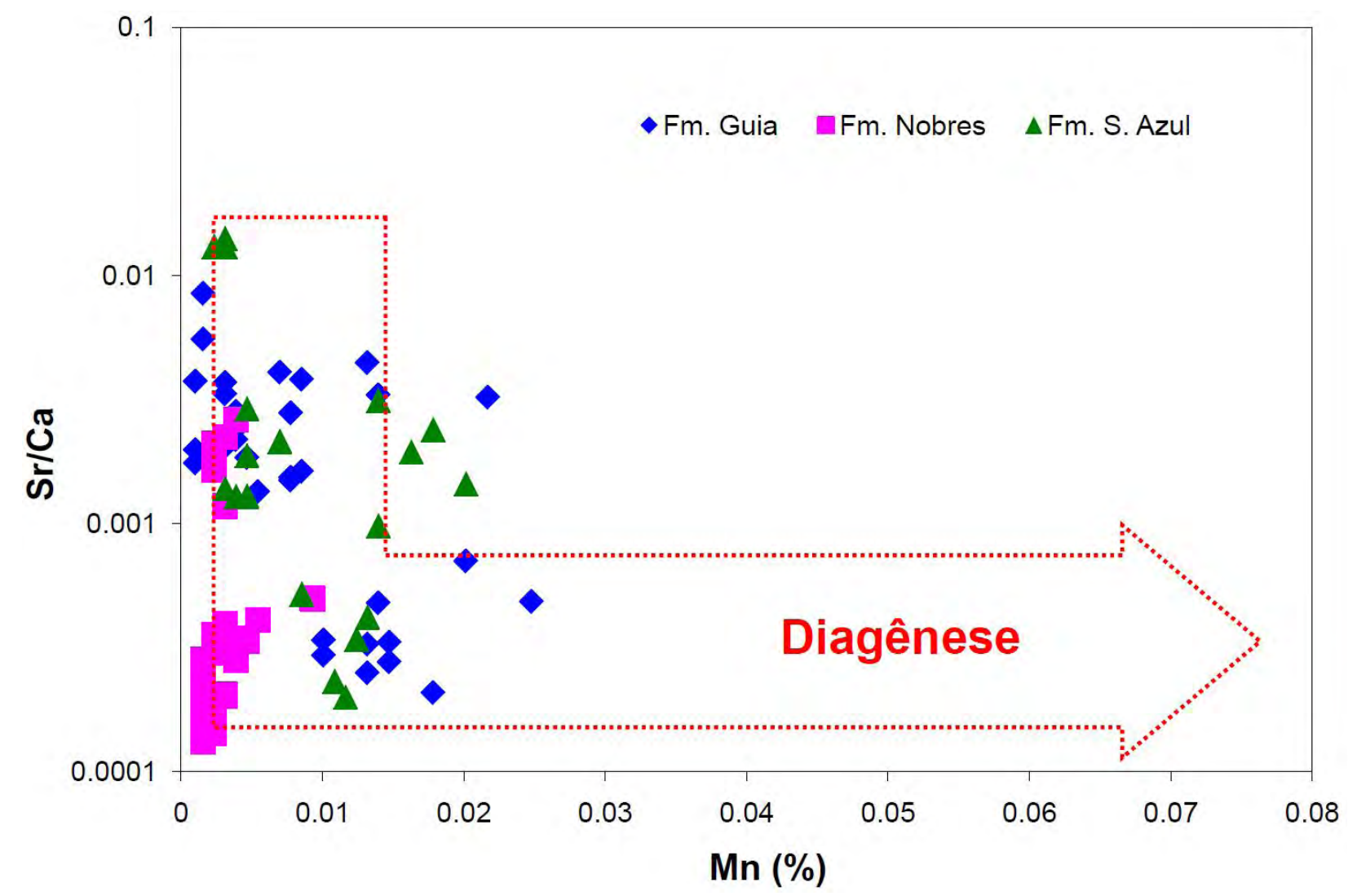

Figura 3. Gráfico Sr/Ca versus Mn mostrando tendência diagenética. A maioria das amostras da Formação Nobres caem no campo de alteração diagenética inicial, com Sr/Ca abaixo de $.0,001$ e teores de Mn baixos.

Quando estes valores são observados no contexto da curva de $\delta^{13} \mathrm{C}$ obtida para a seção da Formação Guia (seção 4, Figura 2), se mostram anomalamente negativos e isolados. Essa tendência negativa de alteração, associada à maturação da MO, pode ser explicada pela reação de descarboxilação termal. Ou seja, a tectônica dúctil-rúptil provocaria o deslizamento entre as camadas mais lubrificadas (ricas em MO), gerando calor suficiente para quebrar as ligações dos compostos orgânicos, com 
conseqüente liberação do radical carboxila $(\mathrm{COOH})$ na forma de $\mathrm{CO}_{2}$. Durante $\mathrm{o}$ deslizamento intra-estratal, espera-se também que tenha ocorrido a recristalização concomitante da calcita. Assim, parte do C liberado pela MO, na qual predomina o ${ }^{12} \mathrm{C}$, pode ter sido utilizado na recristalização mineral, alterando a composição isotópica original da calcita. O resultado esperado para esse processo são calcitas recristalizadas com $\mathrm{C}$ isotopicamente mais leve, refletindo em valores de $\delta^{13} \mathrm{C}$ mais negativos.

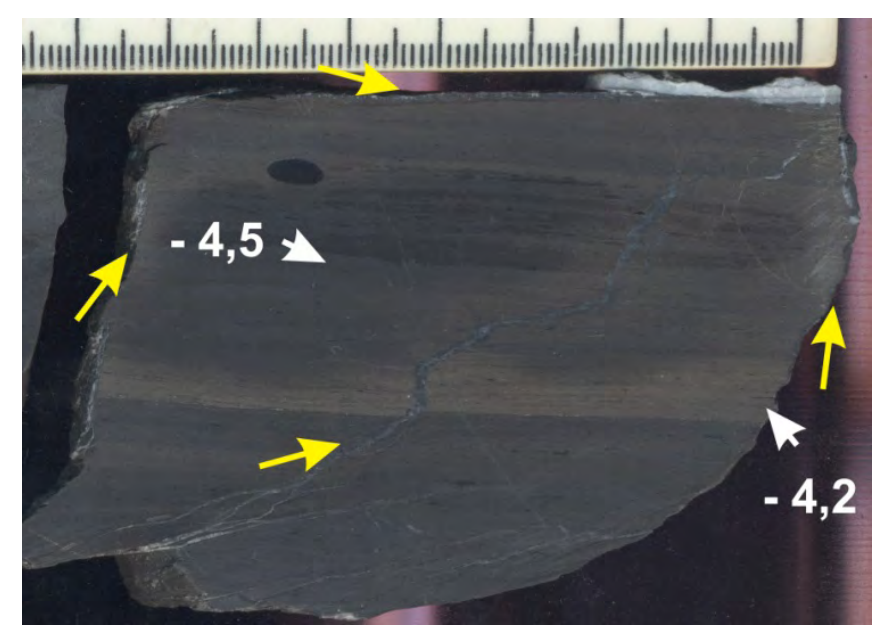

Figura 4. Amostra de calcário finamente laminado rico em matéria orgânica, cisalhado. As setas amarelas mostram planos de fraturamento contendo calcita e betume. Observar a descoloração no entorno delas, devido à migração do óleo. As setas brancas mostram os valores de $\delta^{13} \mathrm{C}$ obtidos nas micro-regiões indicadas.

A título de comparação, foi selecionada outra amostra da mesma formação, uma brecha com predomínio de clastos claros, com raros fragmentos de $\mathrm{MO}$ e cortada por vênulas de calcita. Os resultados de $\delta^{13} \mathrm{C}$ são homogêneos e coerentes com a curva isotópica de $C$ para a seção, sendo os valores de $\delta^{13} C$ obtidos $-1,4 \%$ para um clasto escuro, $-1,4 \%$ para um clasto claro, $-1,2 \%$ para a matriz e $-1,2 \%$ p para a vênula de calcita. Estes valores mostram que os fluídos que percolaram as fraturas tectônicas e a matriz mais porosa possuem valores semelhantes ao da própria rocha afetada, com decréscimo de apenas $0,2 \%$, em amostras com baixo conteúdo de MO.

No caso da Formação Serra Azul, não foram encontradas amostras ricas em MO para avaliar sua influência na alteração dos valores de $\delta^{13} \mathrm{C}$. Então, apenas 2 amostras, contendo vênulas de calcita ou lâminas deformadas por deslizamento intraestratal, foram utilizadas para verificar as possíveis alterações das composições 
isotópicas de C. Na amostra contendo pseudomorfos de cristais de aragonita, os valores negativos são anômalos, entre - 5,6 e - 6,3\%. Uma das lâminas triturada pela tectônica apresentou valor de $\delta^{13} \mathrm{C}$ mais leve, de $-7,4 \%$, com decréscimo de $1 \%$ o do valor mais negativo. Este valor é coerente com os valores obtidos para a amostra, podendo ser representativo desta. No entanto, outra amostra de calcário finamente laminado apresenta valores $\delta^{13} \mathrm{C}$ de $-3,8 \%$, enquanto que a vênula que a corta possui valor mais negativo, de - 7,5\%, indicando que os fluídos posteriores são alóctones. Neste caso, admitem-se duas possíveis fontes para estes fluídos leves: os estratos adjacentes da própria Formação Serra Azul, igualmente anômalos, ou as rochas mais profundas da Formação Guia, como os carbonatos ricos em MO em processo de descarboxilação.

\section{Variação isotópica entre mar raso e profundo}

Ao longo da sucessão carbonática da Faixa Paraguai, pode-se observar uma dependência dos valores isotópicos de $\mathrm{C}$ em relação às fácies sedimentares, especialmente para as formações Guia e Nobres. No entanto, os carbonatos que capeiam os diamictitos glaciais das formações Puga e Serra Azul $\left(\delta^{13} \mathrm{C}\right.$ inferiores a 4\%) não apresentaram tal correlação entre a tendência isotópica e fácies.

Na seção 4 da Formação Guia (Figura 2), os valores isotopicamente mais leves estão associados às fácies de ambientes mais profundos, como calcários negros laminados e ritmitos. Já os valores mais pesados correspondem às fácies mais rasas transportadas talude abaixo por fluxos gravitacionais, como calcários e dolomitos claros na forma de clastos (brechas), slumps e esteiras algais. Essa dependência se mostra mais nítida para o topo, quando ocorre a intercalação mais freqüente de fácies rasas e profundas, mostrando uma variação na assinatura isotópica de até 2,5\%. As bacias oceânicas modernas mantêm um gradiente de $\delta^{13} \mathrm{C}$ ao longo da coluna d'água de cerca de 2\%o (Kroopnik, 1980; Broecker \& Peng, 1982), causado pela fixação de C por fotossíntese restrita à zona fótica, remoção da biomassa produzida na zona de mistura e remineralização da $\mathrm{MO}$ em profundidade.

Em relação à seção 8 da Formação Nobres (Figura 2), os valores isotopicamente mais leves estão associados à exposição da bacia (intermaré a 
supramaré), representada por dolomitos contendo acamamento wavy, gretas e evaporitos. Por outro lado, os valores mais pesados estão associados ao ambiente de inframaré, representado por estratificação cruzada cavalgante, canais preenchidos, estromatólitos colunares e turbiditos. A mesma tendência é encontrada na seção 4, porém com valores mais pesados e sem evidência de exposição. Nesta seção, os valores tendem ao negativo nas fácies associadas à intermaré superior, com possível restrição, enquanto que os valores tendendo a positivo estão associados às fácies de intermaré inferior e inframaré.

A tendência isotópica mais leve, observada na seção 8 (Figura 2), pode ter sido guiada pela bioatividade em ambiente redutor. As salmouras presentes nas porções mais rasas e evaporíticas são saturadas em sulfato, necessário à alimentação de bactérias sulfato-redutoras (BSR), presentes no substrato a milímetros da superfície. As BSR, através da respiração, liberam preferencialmente ${ }^{12} \mathrm{C}\left(\mathrm{CO}_{2}\right)$ para o meio. Na interface sedimento/água, normalmente são encontrados os organismos fotossintetizantes que consomem preferencialmente ${ }^{12} \mathrm{C}\left(\mathrm{CO}_{2}\right)$, fazendo com que o meio fique enriquecido em ${ }^{13} \mathrm{C}$. A ocorrência freqüente de períodos de exposição pode reduzir drasticamente a produtividade das cianobactérias e oxidar parte da MO produzida, devolvendo parte do ${ }^{12} \mathrm{C}$ para o ambiente. Adicionalmente, mantendo-se o substrato úmido e com sulfato disponível, as BSR continuariam reciclando os restos orgânicos, liberando ${ }^{12} \mathrm{CO}_{2}$ para o ambiente (Jorgensen, 1982) até o esgotamento do $\mathrm{SO}_{4}$ disponível ou nova inundação.

As composições isotópicas de $\mathrm{C}$ mais pesadas para a Formação Nobres (seções 7 e 8, Figura 2) podem ser explicadas pela não-inibição ou pelo restabelecimento dos organismos fotossintetizantes nos ambientes de intermaré inferior e inframaré, mais oxigenados e abertos. Provavelmente estes valores se aproximam mais da composição isotópica do carbono inorgânico dissolvido na água do mar na plataforma ( $590 \mathrm{Ma}$ ) que aqueles associados aos períodos de restrição e exposição.

\section{Quimioestratigrafia da Faixa Paraguai}

A composição isotópica do C na superfície dos oceanos é dirigida por reações bio-geoquímicas, que ocorrem ao longo do ciclo do carbono e são sensíveis às 
mudanças ambientais, climáticas ou geológicas. Assim, o uso dos isótopos de C como ferramenta estratigráfica deve levar em consideração as tendências isotópicas que registram um evento, mais que os valores absolutos, pois estes podem variar em até 2,5\% conforme a profundidade ao longo da plataforma, como observado neste trabalho.

As razões isotópicas de Sr são mais homogêneas nos oceanos e apresenta um aumento gradativo através do Ediacarano, como conseqüência das orogenias gondwânicas. As razões ${ }^{87} \mathrm{Sr} /{ }^{86} \mathrm{Sr}$ para o Ediacarano iniciam com um rápido aumento de 0,7074 a 0,7080, logo após a glaciação Marinoana, seguido de uma estabilização ao redor de 0,7075 até a metade do período, quando aumenta gradativamente para razões ao redor de 0,7087, associadas com a anomalia Shuram-Wonoka, seguido de um suave declínio na transição com o Cambriano (Halverson et al., 2007). Assim, as razões iniciais ${ }^{87} \mathrm{Sr} /{ }^{86} \mathrm{Sr}$ em carbonatos podem ser utilizadas na calibração temporal relativa das curvas isotópicas de $\delta^{13} \mathrm{C}$, exigindo uma rigorosa seleção de amostras não alteradas por processos pós-deposicionais (Denison et al., 1994; Jacobsen \& Kaufman, 1999).

O início do Ediacarano na Faixa Paraguai é facilmente reconhecido pela anomalia negativa de $\mathrm{C}$ presente nos dolomitos que recobrem a Formação Puga ao longo de toda a bacia precursora (seções 3 e 13, Figura 2; e.g. Nogueira et al., 2003; Alvarenga et al., 2004; Nogueira et al., 2007; Font et al., 2006; Riccomini et al., 2007; Alvarenga et al., 2008, 2010) e que está associada ao Evento Glacial Marinoano, presente em diversos paleocontinentes. Esta anomalia se inicia com valores de $\delta^{13} \mathrm{C}$ ao redor de - 5\%, geralmente associados a altas razões ${ }^{87} \mathrm{Sr} /{ }^{86} \mathrm{Sr}$ iniciais $(\sim 0,7080)$, possivelmente como conseqüência da intensa erosão gerada pela deglaciação. Seguindo-se a estes valores, desenvolve-se uma excursão até valores de $\delta^{13} \mathrm{C}$ próximos de 0\% em calcários da Formação Guia (seções 0, 3 e 13, Figura 2), acompanhada por razões ${ }^{87} \mathrm{Sr} /{ }^{86} \mathrm{Sr}$ menos radiogênicas, oscilando em torno de 0,7075 (seções 0 e 13, Figura 2), que se mantêm até as últimas camadas de calcário do Grupo Araras (seção 0, Figura 2).

Na segunda metade da Formação Guia, a curva de $\delta^{13} \mathrm{C}$ oscila com incursões até valores por volta de - 2\%o (seções 0 e 4, Figura 2), seguidas por excursões até valores próximos de 0\% para a base da Formação Nobres (seções 0 e 6, Figura 2). Na 
segunda metade do Grupo Araras, a curva de $\delta^{13} \mathrm{C}$ possui poucos dados (seção 0 , Figura 2) e não há dados isotópicos de Sr, sendo difícil a correlação entre as seções. No entanto, os dados disponíveis mostram valores predominantemente positivos, sempre associados a seções com alta freqüência e abrangência de estromatólitos. A correlação entre a seção 0 e a seção 7 é tentativa (Figura 2), devido à escassez de dados, tendo-se utilizado como reforço correlativo a semelhança de fácies, pois estas duas seções fazem parte da mesma sinclinal e se encontram em posições estratigráficas semelhantes.

No topo da seção 0, uma superfície erosiva coloca os depósitos de maré arenosos da Formação Raizama diretamente sobre os estromatólitos colunares ramificados (tipo cérebro?) da Formação Nobres. Neste hiato, os estratos de topo da Formação Nobres e de toda a Formação Serra Azul, correspondentes das seções 8, 11 e 12 (Figura 2), foram removidos ou não se depositaram, dificultando a correlação quimioestratigráfica.

No caso das seções 11 e 12, pertencentes à Formação Serra Azul, o único controle estratigráfico é o seu posicionamento entre os dolomitos da Formação Nobres e os arenitos da Formação Raizama, distando cerca de 300 km uma seção da outra. Estas informações não permitem uma correlação estratigráfica mais refinada entre elas, pois os valores de $\delta^{13} \mathrm{C}$ são bastante distintos e os afloramentos escassos. Neste caso, o posicionamento estratigráfico só é possível pelas razões ${ }^{87} \mathrm{Sr} /{ }^{86} \mathrm{Sr}$. Os carbonatos da seção 12 possuem razões ${ }^{87} \mathrm{Sr} /{ }^{86} \mathrm{Sr}$ mais radiogênicas que os da seção 11 (Figura 2), o que sugere um posicionamento estratigráfico daquela acima desta, considerando a evolução das razões ${ }^{87} \mathrm{Sr} /{ }^{86} \mathrm{Sr}$ ao longo do Ediacarano (Halverson et al., 2007).

\section{Anomalias negativas e eventos glaciais no mundo}

$\mathrm{Na}$ área de estudo, ao longo da estratigrafia, foram reconhecidas duas anomalias fortemente negativas associadas a carbonatos pós-glaciais: N1 (até - 6 \%o) e N2 (até - 7,5\%). A anomalia negativa N1 ocorre imediatamente acima dos diamictitos da Formação Puga, sendo os litotipos constituídos de dolomudstones róseos com laminação rítmica (seção 13, Figura 2) ou de wackestones cinza em seqüência 
turbidítica (seção 3, Figura 2). A anomalia N2 foi encontrada em calcários puros, contendo pseudomorfos de aragonita, depositados acima dos siltitos que capeiam os diamictitos da Formação Serra Azul (seção 11, Figura 2).

Estas anomalias negativas estão intimamente associadas à transgressão e máxima inundação pós-glaciais. A anomalia N1 é acompanhada por uma razão ${ }^{87} \mathrm{Sr} /{ }^{86} \mathrm{Sr}$ de 0,7080 e seguida por composições isotópicas menos radiogênicas ( 0.7075), cujos valores de $\delta^{13} \mathrm{C}$ e razões ${ }^{87} \mathrm{Sr} /{ }^{86} \mathrm{Sr}$ são comparáveis àqueles identificados nas capas carbonáticas de sucessões pós-Glaciação Marinoana (Kaufman \& Knoll, 1995; Hoffman et al., 1998). Nogueira et al. (2003) e Alvarenga et al. (2004) já haviam identificado os carbonatos de capa no Domínio Cratônico, na cidade de Mirassol d'Oeste, e sugerido tal correlação. Porém, a continuação lateral destes carbonatos de capa em direção à bacia é pouco estudada. Na região plataformal (Domínio Externo), os dolomitos que recobrem a Formação Puga apresentam cor rosa, laminação plano-paralela rítmica e biogênica, enquanto que em ambiente mais distal (Domínio Interno) apresentam-se negros e associados a seqüências turbidíticas. Ou seja, a anomalia negativa pós-Marinoana encontrada nos carbonatos da Faixa Paraguai não apresentou dependência de fácies ao longo da plataforma, tendo afetado tanto ambientes plataformais quanto bacinais.

A anomalia Serra Azul (N2) está associada às razões ${ }^{87} \mathrm{Sr} /{ }^{86} \mathrm{Sr}$ mais radiogênicas, entre 0,7083 e 0,7086, que se assemelham àquelas associadas tanto à anomalia N2 da Formação Doushantuo, quanto à expressiva anomalia Shuram. A anomalia N2-Doushantuo (Jiang et al., 2007; McFadden et al., 2008; Sawaki et al., 2010) é anterior à anomalia Wonoka-Shuram (Fike et al., 2006; Le Guerroue et al., 2006) e parece corresponder a um evento mais curto que esta última. As razões ${ }^{87} \mathrm{Sr} /{ }^{86} \mathrm{Sr}$ associadas a estas anomalias coincidem parcialmente, apresentando razões de 0,7083 a 0,7086 para a N2-Doushantuo (Sawaki et al., 2010), enquanto que a anomalia Shuram apresenta razões de 0,7084 a 0,7088 (Christie-Blick et al., 1995; Calver, 2000).

A correlação da anomalia Serra Azul (N2) com uma das anomalias supracitadas é dificultada pela ausência de registro glacial ediacarano nestas sucessões carbonáticas estudadas em Oman, Austrália, Estados Unidos, China e Sibéria. Por outro lado, os depósitos glaciais equivalentes da Formação Gaskiers 
(Newfoundland) carecem de carbonatos de capa que permitam um estudo quimioestratigráfico mais detalhado. Estas sucessões "gaskieranas", com controle geocronológico, têm sido encontradas na Avalônia (Thompson \& Bowring, 2000), Escócia e Irlanda (Condon \& Prave, 2000; Dempster et al., 2002) e, possivelmente, Noruega (Bingen et al., 2005; Halverson et al., 2005) e norte da China (Xiao et al., 2004). Esta última ocorrência apresenta uma fina camada carbonática com valores negativos de $\delta^{13} \mathrm{C}$, no entanto são muito variáveis (Xiao et al., 2004)

A Formação Serra Azul se assemelha à Formação Gaskiers (Newfoundland), em termos litoestratigráficos e isotópicos (Myrow \& Kaufman, 1999). A Formação Gaskiers apresenta uma camada de $50 \mathrm{~cm}$ de calcário laminado, separado dos diamictitos por pelitos vermelhos, considerados como depósitos de máxima inundação relativa à deglaciação. O calcário da Formação Gaskiers possui valores de $\delta^{13} \mathrm{C}$ entre 6\% (base) e - 1,5\% (topo; Myrow \& Kaufman, 1999), semelhantes aos encontrados para a Formação Serra Azul (seções 11 e 12, Figura 2). No entanto, a Formação Gaskiers não dispõe de razões ${ }^{87} \mathrm{Sr} /{ }^{86} \mathrm{Sr}$ primárias devido à recristalização de seus carbonatos, além de ter baixo conteúdo de Sr (34 a 300 ppm) e altas razões Mn/Sr (17 a 77; Myrow \& Kaufman, 1999). Diante da limitação do estudo quimioestratigráfico da Formação Gaskiers, trabalhos recentes têm desconectado a anomalia Wonoka-Shuram da Glaciação Gaskiers (Condon et al., 2005; Le Guerroué et al., 2006). Assim, a Formação Serra Azul é a primeira sucessão a apresentar um conjunto de dados isotópicos de $\delta^{13} \mathrm{C}$ negativamente anômalos, intimamente associados à uma glaciação ediacarana, e com razões ${ }^{87} \mathrm{Sr} /{ }^{86} \mathrm{Sr}$ coerentes com a evolução da água do mar no período.

\section{O Mar Ediacarano}

Os valores de $\delta^{13} \mathrm{C}$ determinados nos carbonatos da Faixa Paraguai Norte, considerados representativos da água do mar, mostraram dois comportamentos distintos, um anômalo com valores semelhantes aos mantélicos (- 7 a $-5 \%$ ), associados ao fim de duas glaciações, e outro com valores levemente negativos a positivos relacionados à variação de fácies, com variações aceitáveis quando comparadas aos oceanos contemporâneos. 
Tabela 2. Resultados das análises isotópicas de C, O e Sr, juntamente com parâmetros químicos de avaliação de alterações pós-deposicionais.

\begin{tabular}{|c|c|c|c|c|c|c|c|c|c|c|c|}
\hline & metros & amostra & $\begin{array}{c}\delta^{13} \mathrm{C} \\
\text { (Carb) }\end{array}$ & $\delta^{18} 0$ & ${ }^{87} \mathrm{Sr} l^{86} \mathrm{Sr}$ & $\begin{array}{l}\text { Mn } \\
(\%)\end{array}$ & $\begin{array}{l}\mathrm{Fe} \\
(\%)\end{array}$ & $\begin{array}{c}\mathrm{Sr} \\
(\mathrm{ppm})\end{array}$ & $\mathrm{Sr} / \mathrm{Ca}$ & $\mathrm{Rb} / \mathrm{Sr}$ & Sr/Mn \\
\hline \multirow{51}{*}{ 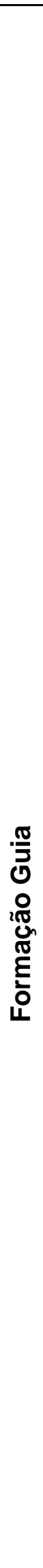 } & 53 & PS-1 & -0.35 & -4.07 & & 0.013 & 0.37 & 48 & 0.0003 & 0.313 & 0.37 \\
\hline & 52 & PS-2 & -1.06 & -6.05 & & 0.010 & 0.25 & 56 & 0.0003 & 0.234 & 0.56 \\
\hline & 51 & PS-3 & -1.03 & -4.84 & & 0.015 & 0.92 & 53 & 0.0003 & 0.746 & 0.36 \\
\hline & 50 & PS-4 & -1.24 & -4.32 & & 0.013 & 0.76 & 56 & 0.0003 & 0.583 & 0.42 \\
\hline & 49 & PS-5 & -0.95 & -4.70 & & 0.014 & 0.43 & 90 & 0.0005 & 0.319 & 0.64 \\
\hline & 41 & PS-6 & -1.96 & -4.20 & & 0.010 & 0.24 & 56 & 0.0003 & 0.271 & 0.55 \\
\hline & 31 & PS-07 & -2.34 & -3.72 & & & & & & & \\
\hline & 26 & PS-8 & -1.29 & -3.42 & & 0.018 & 0.36 & 40 & 0.0002 & 0.404 & 0.23 \\
\hline & 19 & PS-9 & -1.74 & -3.51 & & 0.015 & 0.27 & 50 & 0.0003 & 0.377 & 0.34 \\
\hline & 23 & PS-10 & -1.95 & -3.52 & & & & & & & \\
\hline & 8 & PS-11 & -4.29 & -5.99 & & 0.020 & 0.34 & 177 & 0.0007 & 0.087 & 0.88 \\
\hline & 0.2 & PS43 & -5.58 & -7.14 & & & & & & & \\
\hline & 0.4 & PS44 & -5.08 & -8.22 & & & & & & & \\
\hline & 0.4 & PS45 & -5.26 & -7.32 & & & & & & & \\
\hline & 0.8 & PS46 & -5.19 & -7.59 & & & & & & & \\
\hline & 1.2 & PS47b & -6.25 & -7.81 & & & & & & & \\
\hline & 1.2 & PS47a & -3.50 & -6.12 & & & & & & & \\
\hline & 1.6 & PS48 & -4.39 & -7.76 & & & & & & & \\
\hline & 2.5 & PS49 & -4.66 & -7.63 & 0.70805 & & & & & & \\
\hline & 3.2 & PS50 & -4.17 & -8.06 & & & & & & & \\
\hline & 6.7 & PS51 & -5.47 & -6.92 & & & & & & & \\
\hline & 0.0 & co01a & -0.48 & -7.45 & & & & & & & \\
\hline & 0.0 & $\mathrm{co01b}$ & -0.23 & -7.17 & & & & & & & \\
\hline & 0.0 & coolc & -0.41 & -7.32 & & & & & & & \\
\hline & 1.0 & $\mathrm{CO} 2$ & -0.25 & -6.82 & & & & & & & \\
\hline & 2.0 & $\mathrm{CO03}$ & & & & & & & & & \\
\hline & 3.0 & $\mathrm{COO4}$ & & & & & & & & & \\
\hline & 4.0 & CO05 & & & & & & & & & \\
\hline & 5.0 & CO06 & -0.57 & -6.87 & 0.70765 & & & & & & \\
\hline & 6.0 & $\mathrm{CO} 07$ & & & & & & & & & \\
\hline & 7.0 & CO08 & & & & 0.004 & 0.15 & 1013 & & & \\
\hline & 8.0 & COO9 & & & & 0.002 & 0.05 & 661 & & & \\
\hline & 9.0 & CO10 & -1.11 & -7.58 & & 0.004 & 0.10 & 798 & & & \\
\hline & 10.0 & CO11 & & & & 0.003 & 0.07 & 440 & & & \\
\hline & 11.0 & CO12 & & & & 0.003 & 0.06 & 70 & & & \\
\hline & 12.0 & CO13 & & & & 0.004 & 0.12 & 932 & & & \\
\hline & 13.0 & CO14 & -0.72 & -7.14 & & 0.003 & 0.11 & 1262 & & & \\
\hline & 14.0 & C015 & & & & 0.003 & 0.08 & 45 & & & \\
\hline & 15.0 & Co16 & & & & 0.002 & 0.06 & 640 & & & \\
\hline & 16.0 & CO17 & & & & 0.002 & 0.03 & 37 & & & \\
\hline & 17.0 & C018 & -0.76 & -6.64 & & 0.002 & 0.01 & 50 & & & \\
\hline & 18.0 & CO19 & & & & 0.002 & 0.02 & 63 & & & \\
\hline & 19.0 & $\mathrm{CO} 20$ & & & & 0.002 & 0.02 & 36 & & & \\
\hline & 20.0 & CO21 & & & & 0.003 & 0.09 & 44 & & & \\
\hline & 21.0 & $\mathrm{CO} 22$ & -6.23 & -6.82 & & 0.002 & 0.03 & 824 & & & \\
\hline & 22.0 & $\mathrm{CO} 23$ & & & & 0.002 & 0.06 & 629 & & & \\
\hline & 23.0 & $\mathrm{CO} 24$ & & & & 0.002 & 0.04 & 636 & & & \\
\hline & 24.0 & $\mathrm{CO} 25$ & & & & 0.002 & 0.05 & 794 & & & \\
\hline & 25.0 & CO26a & -1.01 & -7.02 & & 0.003 & 0.02 & 862 & & & \\
\hline & 25.0 & CO26b & -0.81 & -7.17 & & 0.002 & 0.03 & 36 & & & \\
\hline & 26.0 & $\mathrm{CO} 27$ & & & & 0.002 & 0.03 & 39 & & & \\
\hline
\end{tabular}




\begin{tabular}{|c|c|c|c|c|c|c|c|c|c|c|c|}
\hline & metros & amostra & $\begin{array}{c}\delta^{13} \mathrm{C} \\
\text { (Carb) }\end{array}$ & $\delta^{18} \mathrm{O}$ & $\left.{ }^{87} \mathrm{Sr}\right|^{86} \mathrm{Sr}$ & $\begin{array}{l}\mathrm{Mn} \\
(\%)\end{array}$ & $\begin{array}{l}\mathrm{Fe} \\
(\%)\end{array}$ & $\begin{array}{c}\mathrm{Sr} \\
(\mathrm{ppm})\end{array}$ & Sr/Ca & $\mathrm{Rb} / \mathrm{Sr}$ & Sr/Mn \\
\hline & 27.0 & CO28 & & & & 0.002 & 0.01 & 36 & & & \\
\hline & 28.0 & $\mathrm{CO} 29$ & -1.59 & -7.14 & & 0.002 & 0.01 & 43 & & & \\
\hline & 29.0 & $\mathrm{CO} 30$ & -2.04 & -7.06 & & 0.002 & 0.01 & 79 & & & \\
\hline & 30.0 & CO31 & & & & 0.002 & 0.05 & 32 & & & \\
\hline & 31.0 & $\mathrm{CO} 32$ & & & & 0.002 & 0.01 & 29 & & & \\
\hline & 32.0 & $\mathrm{CO} 33$ & & & & 0.002 & 0.02 & 30 & & & \\
\hline & 33.0 & $\mathrm{CO} 34$ & -1.56 & -7.68 & & 0.002 & 0.01 & 52 & & & \\
\hline & 34.0 & CO35 & & & & 0.005 & 0.06 & 87 & & & \\
\hline & 35.0 & CO36 & & & & 0.004 & 0.06 & 62 & & & \\
\hline & 36.0 & $\mathrm{CO} 37$ & -0.59 & -7.58 & & 0.003 & 0.05 & 70 & & & \\
\hline & 36.0 & co37teste & & & & 0.009 & 0.17 & 78 & & & \\
\hline & 37.0 & $\mathrm{CO} 38$ & -0.75 & -7.39 & & 0.005 & 0.06 & 74 & & & \\
\hline & 38.0 & CO39 & & & & 0.003 & 0.02 & 76 & & & \\
\hline & 39.0 & CO40 & & & & 0.004 & 0.02 & 75 & & & \\
\hline & 40.0 & CO41 & & & & 0.003 & 0.02 & 87 & & & \\
\hline & 41.0 & $\mathrm{CO} 42$ & -1.59 & -7.62 & & 0.020 & 0.20 & 548 & & & \\
\hline & 42.0 & $\mathrm{CO} 43$ & -2.82 & -7.32 & & 0.014 & 0.27 & 1152 & & & \\
\hline & 43.0 & $\mathrm{CO} 44$ & -1.61 & -7.46 & 0.70737 & 0.018 & 0.27 & 885 & & & \\
\hline & 44.0 & CO45 & -2.29 & -7.43 & & 0.014 & 0.12 & 376 & & & \\
\hline & 45.0 & CO46 & -2.02 & -7.79 & & 0.007 & 0.12 & 820 & & & \\
\hline & 46.0 & co47a & -1.17 & -8.07 & & 0.016 & 0.11 & 744 & & & \\
\hline & 46.0 & $\mathrm{cO} 47 \mathrm{~b}$ & -1.39 & -7.29 & & 0.005 & 0.04 & 741 & & & \\
\hline & 46.0 & $\mathrm{CO} 47 \mathrm{c}$ & -1.19 & -8.31 & & 0.012 & 0.09 & 44 & & & \\
\hline & 46.0 & co47d & -1.42 & -8.08 & & 0.009 & 0.19 & 117 & & & \\
\hline & 47.0 & $\mathrm{CO} 48$ & -1.76 & -7.75 & & 0.011 & 0.10 & 51 & & & \\
\hline \multirow{29}{*}{ 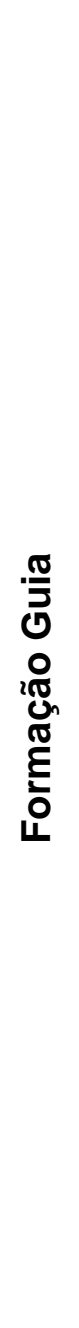 } & 48.0 & $\mathrm{CO} 49$ & -0.87 & -7.43 & 0.7076 & 0.013 & 0.14 & 89 & & & \\
\hline & 49.0 & c050a & -4.19 & -7.60 & & 0.012 & 0.12 & 74 & & & \\
\hline & 49.0 & co50b & -4.46 & -7.46 & & 0.004 & 0.14 & 426 & & & \\
\hline & 51.0 & CO51 & -1.92 & -7.52 & & 0.005 & 0.27 & 402 & & & \\
\hline & 55.0 & CO53 & -1.05 & -7.11 & 0.70743 & 0.005 & 0.05 & 1140 & & & \\
\hline & 57.0 & CO54 & -1.53 & -6.94 & & 0.003 & 0.07 & 526 & & & \\
\hline & 59.0 & C055 & -2.23 & -8.17 & & 0.003 & 0.06 & 5452 & & & \\
\hline & 59.0 & c055rep & & & & 0.002 & 0.06 & 5017 & & & \\
\hline & 61.0 & C056 & -1.61 & -7.34 & & 0.003 & 0.17 & 4865 & & & \\
\hline & 63.0 & $\mathrm{CO} 57$ & -1.19 & -7.88 & & 0.010 & 0.07 & 82 & & & \\
\hline & 65.0 & c058a & -1.00 & -8.52 & & 0.010 & 0.06 & 66 & & & \\
\hline & 65.0 & co58b & & -8.59 & & 0.010 & 0.06 & 63 & & & \\
\hline & 67.0 & CO59 & -2.44 & -8.24 & & 0.010 & 0.08 & 69 & & & \\
\hline & 69.0 & C060 & -2.47 & -7.95 & 0.70744 & 0.010 & 0.38 & 63 & & & \\
\hline & 7.5 & FS119-01 & -0.25 & -8.77 & & 0.010 & 0.36 & 63 & & & \\
\hline & 8.4 & FS119-03 & -0.07 & -8.33 & & 0.010 & 0.31 & 91 & & & \\
\hline & 9.3 & FS119-04 & -0.35 & -8.45 & & 0.060 & 0.71 & 208 & 0.0009 & 0.115 & 0.35 \\
\hline & 10.2 & FS119-05 & -0.54 & -7.92 & & 0.100 & 2.22 & 134 & 0.0014 & 0.880 & 0.13 \\
\hline & 11 & FS119-06 & -1.45 & -9.52 & 0.70746 & 0.030 & 0.45 & 446 & 0.0012 & 0.021 & 1.49 \\
\hline & 12 & FS119-07 & -1.42 & -9.05 & & 0.020 & 0.08 & 416 & 0.0011 & 0.020 & 2.08 \\
\hline & 13.15 & FS119-08 & -1.24 & -9.00 & & 0.020 & 0.08 & 383 & 0.0010 & 0.026 & 1.92 \\
\hline & 14.1 & FS119-09 & -1.21 & -9.40 & & 0.010 & 0.14 & 644 & 0.0016 & 0.009 & 6.33 \\
\hline & 19.5 & FS119-11 & -1.00 & -8.27 & 0.70757 & 0.010 & 0.14 & 667 & 0.0019 & 0.021 & 6.67 \\
\hline & 20.4 & FS119-12 & -1.11 & -8.37 & & 0.010 & 0.16 & 683 & 0.0019 & 0.015 & 6.83 \\
\hline & 21.6 & FS119-13 & -1.11 & -8.35 & 0.70748 & 0.010 & 0.09 & 1641 & 0.0043 & 0.005 & 16.41 \\
\hline & 22.5 & FS119-14 & -1.20 & -8.27 & & 0.020 & 0.28 & 823 & 0.0025 & 0.024 & 4.11 \\
\hline & 23.6 & FS119-15 & -1.17 & -8.39 & 0.70725 & 0.020 & 0.31 & 967 & 0.0028 & 0.020 & 4.83 \\
\hline & 24.5 & FS119-16 & -1.17 & -8.94 & 0.70744 & 0.010 & 0.22 & 690 & 0.0018 & 0.011 & 6.90 \\
\hline & 25.5 & FS119-17 & -1.10 & -8.75 & & 0.010 & 0.11 & 583 & 0.0016 & 0.015 & 5.83 \\
\hline
\end{tabular}




\begin{tabular}{|c|c|c|c|c|c|c|c|c|c|c|}
\hline metros & amostra & $\begin{array}{l}\delta^{13} \mathrm{C} \\
\text { (Carb) }\end{array}$ & $\delta^{18} \mathrm{O}$ & ${ }^{87} \mathrm{Srl}{ }^{86} \mathrm{Sr}$ & $\begin{array}{l}\text { Mn } \\
\text { (\%) }\end{array}$ & $\begin{array}{l}\mathrm{Fe} \\
(\%)\end{array}$ & $\begin{array}{c}\mathrm{Sr} \\
(\mathrm{ppm})\end{array}$ & $\mathrm{Sr} / \mathrm{Ca}$ & $\mathrm{Rb} / \mathrm{Sr}$ & Sr/Mn \\
\hline 26.5 & FS119-18 & -1.03 & -8.74 & 0.70741 & 0.010 & 0.27 & 883 & 0.0023 & 0.009 & 8.83 \\
\hline 27.5 & FS119-19 & -1.03 & -8.80 & & 0.010 & 0.29 & 750 & 0.0021 & 0.021 & 7.50 \\
\hline 28.5 & FS119-20 & -1.06 & -8.49 & & 0.020 & 0.31 & 616 & 0.0018 & 0.028 & 3.08 \\
\hline 29.5 & FS119-21 & -0.93 & -8.60 & 0.70743 & 0.020 & 0.22 & 1025 & 0.0028 & 0.013 & 5.13 \\
\hline 30.5 & FS119-22 & -1.40 & -9.20 & & 0.030 & 0.26 & 466 & 0.0013 & 0.041 & 1.55 \\
\hline 31.5 & FS119-23 & -2.11 & -9.73 & & 0.050 & 1.53 & 331 & 0.0021 & 0.215 & 0.66 \\
\hline 32.5 & FS119-24 & -1.90 & -8.57 & & & & & & & \\
\hline 33.6 & FS119-25 & -1.90 & -9.03 & & & & & & & \\
\hline 35.1 & FS119-26 & -1.82 & -7.49 & & & & & & & \\
\hline 36.6 & FS119-27 & -1.95 & -8.97 & & & & & & & \\
\hline 37.75 & FS119-28 & -2.26 & -9.25 & & & & & & & \\
\hline 38.75 & FS119-29 & -2.17 & -9.57 & & & & & & & \\
\hline 39.4 & FS119-30 & -1.77 & -7.47 & & & & & & & \\
\hline 40.5 & FS119-31 & -1.95 & -8.72 & & & & & & & \\
\hline 42.5 & FS119-33 & -1.84 & -8.25 & & & & & & & \\
\hline 43.5 & FS119-34 & -2.53 & -9.58 & & & & & & & \\
\hline 44.45 & FS119-35 & -2.27 & -8.90 & & & & & & & \\
\hline 45.5 & FS119-36 & -2.79 & -8.53 & & & & & & & \\
\hline 46.5 & FS119-37 & -2.47 & -8.96 & & & & & & & \\
\hline 48.5 & FS119-39 & -2.64 & -9.64 & & & & & & & \\
\hline 49.5 & FS119-40 & -2.71 & -9.20 & & & & & & & \\
\hline 50.6 & FS119-41 & -2.82 & -10.30 & & & & & & & \\
\hline 51.5 & FS119-42 & -2.97 & -10.30 & & & & & & & \\
\hline 52.5 & FS119-43 & -2.91 & -9.21 & & & & & & & \\
\hline 53.4 & FS119-44 & -2.18 & -7.06 & & & & & & & \\
\hline 54.5 & FS119-45 & -2.85 & -7.82 & & & & & & & \\
\hline 55.4 & FS119-46 & -2.90 & -6.51 & & & & & & & \\
\hline 56.5 & FS119-47 & -3.05 & -6.61 & & & & & & & \\
\hline 61 & FS119-49 & -7.10 & -12.55 & & & & & & & \\
\hline 62.1 & FS119-50 & -4.53 & -5.91 & & & & & & & \\
\hline 63.15 & FS119-51 & -4.66 & -8.95 & & & & & & & \\
\hline 64.1 & FS119-52 & -3.55 & -7.38 & & & & & & & \\
\hline 65.2 & FS119-53 & -3.95 & -7.11 & & & & & & & \\
\hline 66.6 & FS119-54 & -3.97 & -6.75 & & & & & & & \\
\hline 69 & FS119-55 & -4.33 & -6.49 & & & & & & & \\
\hline 70 & FS119-56 & -4.47 & -7.05 & & & & & & & \\
\hline 70.7 & FS119-57 & -4.06 & -6.63 & & & & & & & \\
\hline 0.0 & MT01 & -0.93 & -4.27 & & & & & & & \\
\hline 6.5 & MT02 & -0.99 & -5.17 & & & & & & & \\
\hline 11.0 & MT03A & -0.77 & -4.17 & & & & & & & \\
\hline 23.0 & MT03C & -0.73 & -4.35 & & & & & & & \\
\hline 32.0 & MT04 & -1.38 & -4.32 & & & & & & & \\
\hline 34.5 & MT05 & -2.12 & -4.06 & & & & & & & \\
\hline 35.0 & MT06 & -1.61 & -4.16 & & & & & & & \\
\hline 37.0 & МT06B & -0.21 & -5.34 & & & & & & & \\
\hline 42.5 & МT07b & -0.90 & -3.81 & & & & & & & \\
\hline 42.5 & MT07a & -0.97 & -3.06 & & & & & & & \\
\hline 43.0 & MT08 & -1.49 & -3.58 & & & & & & & \\
\hline 45.5 & MT09 & -2.28 & -2.98 & & & & & & & \\
\hline 52.0 & MT10 & -0.22 & -4.63 & & & & & & & \\
\hline 57.0 & MT11 & 0.16 & -4.41 & & & & & & & \\
\hline 59.0 & MT12 & 0.26 & -4.50 & & & & & & & \\
\hline 65.0 & MT12C a & -0.34 & -4.63 & & & & & & & \\
\hline 65.0 & MT12C b & -0.29 & -3.62 & & & & & & & \\
\hline
\end{tabular}




\begin{tabular}{|c|c|c|c|c|c|c|c|c|c|c|c|}
\hline & metros & amostra & $\begin{array}{l}\delta^{13} \mathrm{C} \\
\text { (Carb) }\end{array}$ & $\delta^{18} \mathrm{O}$ & ${ }^{87} \mathrm{Sr} l^{86} \mathrm{Sr}$ & $\begin{array}{l}\text { Mn } \\
\text { (\%) }\end{array}$ & $\begin{array}{l}\mathrm{Fe} \\
(\%)\end{array}$ & $\begin{array}{c}\mathrm{Sr} \\
(\mathrm{ppm})\end{array}$ & Sr/Ca & $\mathrm{Rb} / \mathrm{Sr}$ & Sr/Mn \\
\hline \multirow{54}{*}{ 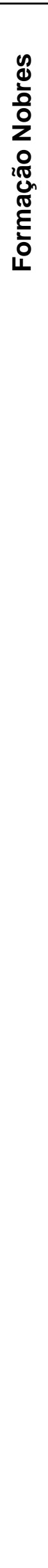 } & 93.0 & MT12E & 0.15 & -3.70 & & & & & & & \\
\hline & 105.0 & MT12G & -0.17 & -4.18 & & & & & & & \\
\hline & 38 & NB-70 & 0.54 & -4.29 & & & & & & & \\
\hline & 36.5 & NB-71 & 0.13 & -4.49 & & & & & & & \\
\hline & 34.5 & NB-73 & 1.51 & -3.72 & & & & & & & \\
\hline & 32.5 & NB-75 & 0.65 & -4.88 & & & & & & & \\
\hline & 30.5 & NB-76 & 0.44 & -4.84 & & & & & & & \\
\hline & 27.5 & NB-77 & 0.40 & -4.05 & & & & & & & \\
\hline & 25.5 & NB-78 & 0.41 & -4.37 & & & & & & & \\
\hline & 22.5 & NB-79 & 0.71 & -3.76 & & & & & & & \\
\hline & 21 & NB-80 & 0.73 & -3.42 & & & & & & & \\
\hline & 19.5 & NB-81 & 0.11 & -5.90 & & & & & & & \\
\hline & 18.5 & NB-82 & -0.27 & -4.14 & & & & & & & \\
\hline & 16.5 & NB-84 & -0.15 & -4.05 & & & & & & & \\
\hline & 15 & NB-85 & -0.07 & -3.95 & & & & & & & \\
\hline & 14.7 & NB-86 & 0.19 & -3.83 & & & & & & & \\
\hline & 14.3 & NB-87 & 0.37 & -3.47 & & & & & & & \\
\hline & 14 & NB-88 & 1.17 & -4.56 & & & & & & & \\
\hline & 13 & NB-89 & 1.03 & -3.97 & & & & & & & \\
\hline & 11.3 & NB-90 & 0.47 & -4.44 & & & & & & & \\
\hline & 10 & NB-91 & 0.35 & -4.35 & & & & & & & \\
\hline & 8.5 & NB-92 & 0.75 & -5.09 & & & & & & & \\
\hline & 3.5 & NB-95 & 0.34 & -4.28 & & & & & & & \\
\hline & 1.5 & NB-96 & 1.14 & -4.53 & & & & & & & \\
\hline & 0 & NB-97 & 0.46 & -4.18 & & & & & & & \\
\hline & 17 & FS184-2 & -1.09 & -4.83 & & & & & & & \\
\hline & 18 & FS184-3 & -1.18 & -5.07 & & 0.010 & 0.07 & 82 & 0.0004 & 0.068 & 0.82 \\
\hline & 19.2 & FS184-4 & -1.15 & -6.31 & & & & & & & \\
\hline & 20.9 & FS184-5 & -1.19 & -6.22 & & & & & & & \\
\hline & 23 & FS184-6 & -1.51 & -6.54 & & & & & & & \\
\hline & 26.9 & FS184-7 & -1.17 & -5.93 & & & & & & & \\
\hline & 29.2 & FS184-8 & -1.12 & -6.80 & & 0.010 & 0.06 & 66 & 0.0003 & 0.015 & 0.66 \\
\hline & 34.75 & FS184-9 & -1.36 & -6.09 & & 0.010 & 0.06 & 63 & 0.0003 & 0.018 & 0.63 \\
\hline & 35.9 & FS184-10 & -1.13 & -5.02 & & & & & & & \\
\hline & 36.8 & FS184-11 & -1.02 & -5.67 & & & & & & & \\
\hline & 41 & FS184-12 & -0.83 & -6.02 & & & & & & & \\
\hline & 42.1 & FS184-13 & -0.83 & -6.38 & & 0.010 & 0.08 & 69 & 0.0003 & 0.019 & 0.69 \\
\hline & 47.95 & FS184-15 & -0.77 & -6.49 & & & & & & & \\
\hline & 48.7 & FS184-16 & -0.35 & -6.17 & & & & & & & \\
\hline & 50.8 & FS184-17 & -0.30 & -5.58 & & 0.010 & 0.38 & 63 & 0.0003 & 0.276 & 0.63 \\
\hline & 52.9 & FS184-18 & -0.48 & -5.87 & & 0.010 & 0.31 & 91 & 0.0004 & 0.120 & 0.91 \\
\hline & 55 & FS184-19 & -0.40 & -5.89 & & & & & & & \\
\hline & 57.1 & FS184-20 & -0.50 & -5.64 & & & & & & & \\
\hline & 59.2 & FS184-21 & -0.10 & -5.66 & & 0.010 & 0.07 & 57 & 0.0003 & 0.009 & 0.57 \\
\hline & 61.3 & FS184-22 & -0.27 & -6.54 & & 0.010 & 0.07 & 64 & 0.0003 & 0.003 & 0.64 \\
\hline & 63.4 & FS184-23 & -0.47 & -6.07 & & & & & & & \\
\hline & 65.5 & FS184-24 & -0.50 & -5.96 & & & & & & & \\
\hline & 67.6 & FS184-25 & -0.82 & -5.78 & & 0.010 & 0.11 & 85 & 0.0004 & 0.069 & 0.85 \\
\hline & 76.0 & NB103a & -3.77 & -5.69 & & & & & & & \\
\hline & 76.0 & NB103b & -7.47 & -6.98 & & & & & & & \\
\hline & 75.8 & NB104 & -3.24 & -5.53 & 0.70838 & & & & & & \\
\hline & 75.6 & NB105 & -3.48 & -6.09 & & & & & & & \\
\hline & 75.1 & NB106 & -3.42 & -5.70 & & & & & & & \\
\hline & 74.9 & NB107 & -4.79 & -6.22 & 0.70849 & & & & & & \\
\hline
\end{tabular}




\begin{tabular}{|c|c|c|c|c|c|c|c|c|c|c|}
\hline metros & amostra & $\begin{array}{c}\delta^{13} \mathrm{C} \\
\text { (Carb) }\end{array}$ & $\delta^{18} \mathrm{O}$ & ${ }^{87} \mathrm{Sr} l^{86} \mathrm{Sr}$ & $\begin{array}{l}\text { Mn } \\
(\%)\end{array}$ & $\begin{array}{l}\mathrm{Fe} \\
(\%)\end{array}$ & $\begin{array}{c}\mathrm{Sr} \\
(\mathrm{ppm})\end{array}$ & Sr/Ca & $\mathrm{Rb} / \mathrm{Sr}$ & Sr/Mn \\
\hline 74.6 & NB108 & -4.71 & -5.97 & & & & & & & \\
\hline 73.4 & NB110 & -5.30 & -7.34 & & & & & & & \\
\hline 73.1 & NB111d & -6.04 & -6.43 & & & & & & & \\
\hline 73.1 & NB111a & -7.28 & -7.61 & & & & & & & \\
\hline 73.1 & NB111b & -5.86 & -6.49 & & & & & & & \\
\hline 73.1 & NB111c & -5.58 & -6.87 & & & & & & & \\
\hline 73.1 & NB111e & -5.67 & -7.07 & & & & & & & \\
\hline 73.1 & NB111f & -6.29 & -7.16 & & & & & & & \\
\hline 73.1 & NB111g & -7.36 & -9.12 & & & & & & & \\
\hline 72.3 & NB112 & -6.40 & -7.34 & & & & & & & \\
\hline 72.1 & NB113 & -4.22 & -6.75 & 0.70839 & & & & & & \\
\hline 72.0 & NB114 & -4.27 & -7.01 & & & & & & & \\
\hline 71.5 & NB115 & -4.73 & -6.86 & & & & & & & \\
\hline 69.5 & NB116 & -4.97 & -7.52 & 0.70832 & & & & & & \\
\hline 69.0 & NB117 & -4.58 & -7.15 & & & & & & & \\
\hline 68.8 & NB118 & -4.73 & -7.33 & & & & & & & \\
\hline 68.71 & $19 \mid$ & -4.99 & -7.02 & & & & & & & \\
\hline 70.317 & $19 \mathrm{H}$ & -4.92 & -6.66 & & & & & & & \\
\hline 71.088 & $19 G$ & -7.47 & -7.61 & 0.70845 & & & & & & \\
\hline 72.409 & $19 \mathrm{~F}$ & -6.51 & -7.69 & & & & & & & \\
\hline 73.209 & $19 E$ & -6.53 & -7.79 & 0.70839 & & & & & & \\
\hline 74.109 & $19 D$ & -3.32 & -5.85 & 0.70855 & & & & & & \\
\hline 76.68 & $19 C$ & -3.21 & -5.55 & 0.70865 & & & & & & \\
\hline 3.9 & $\mathrm{~B} \times 11$ & 0.19 & -3.40 & & 0.012 & 0.12 & 74 & 0.0003 & 0.050 & 0.60 \\
\hline 2.9 & BX09 & 0.28 & -3.90 & & 0.013 & 0.14 & 89 & 0.0004 & 0.044 & 0.67 \\
\hline 1.7 & BX06 & 0.33 & -3.86 & & 0.011 & 0.10 & 51 & 0.0002 & 0.033 & 0.47 \\
\hline 0.8 & BX03 & 0.76 & -3.60 & & 0.009 & 0.19 & 117 & 0.0005 & 0.018 & 1.38 \\
\hline 0 & BX01 & 0.15 & -6.18 & & 0.012 & 0.09 & 44 & 0.0002 & 0.041 & 0.38 \\
\hline-6.5 & BX13 & -0.79 & -5.93 & & 0.004 & 0.14 & 426 & 0.0013 & 0.012 & 11.01 \\
\hline-7.5 & BX14 & -0.58 & -4.60 & & 0.005 & 0.27 & 402 & 0.0013 & 0.029 & 8.64 \\
\hline-8.2 & BX16 & -0.76 & -6.27 & 0.7087 & 0.005 & 0.05 & 1140 & 0.0029 & 0.005 & 24.53 \\
\hline-11.2 & BX18 & -0.72 & -6.16 & 0.70875 & 0.003 & 0.07 & 526 & 0.0014 & 0.007 & 16.99 \\
\hline-29.2 & BX20 & -1.02 & -6.72 & 0.70849 & 0.003 & 0.06 & 5452 & 0.0141 & 0.000 & 175.98 \\
\hline-30.2 & BX21 & -1.08 & -6.81 & 0.70862 & 0.002 & 0.06 & 5017 & 0.0131 & 0.000 & 215.91 \\
\hline-31 & BX22 & -0.97 & -8.79 & 0.70869 & 0.003 & 0.17 & 4865 & 0.0131 & 0.001 & 157.03 \\
\hline
\end{tabular}

Nota: erros de $\delta^{13} \mathrm{C}= \pm 0,05 \%$ e $\delta^{18} \mathrm{O}= \pm 0,07 \%$; valores de deltas normalizados para os padrões V-PDB (carbono) e V-CDT (enxofre) e expressos em\%. 
Anomalias de $\delta^{13} \mathrm{C}$ negativas

As causas da anomalia negativa de $\delta^{13} \mathrm{C}$ encontrada nas capas carbonáticas Marinoanas são alvo de um amplo debate. Inicialmente foram interpretadas como o resultado da inibição dos organismos fotossintetizantes durante uma glaciação global, com uma rápida deposição de carbonatos durante a deglaciação, devido ao aumento da alcalinidade nos oceanos (Hoffman et al., 1998). No entanto, a interpretação de deposição lenta e de longa duração para estas capas carbonáticas (Kennedy, 1996), com o registro de várias reversões paleomagnéticas (Trindade et al., 2003), contrasta com a rápida deposição pós-glacial. Outras interpretações, associadas à transgressão marinha durante a deglaciação, são o descongelamento do permafrost inundado, provocando a desestabilização de hidrato de metano com valores de $\delta^{13} \mathrm{C}$ extremamente negativos (Kennedy et al., 2001; Jiang et al, 2003), e a ocorrência de upwellings durante a transgressão, transportando águas profundas empobrecidas em ${ }^{13} \mathrm{C}$ para a plataforma.

As anomalias negativas encontradas nos carbonatos acima da Formação Puga (N1 nas seções 3 e 13, Figura 2) não permitem resolver o debate sobre suas possíveis causas. No entanto, sua ocorrência constante ao longo de toda a bacia, da plataforma eufótica (Nogueira et al., 2003; Alvarenga et al., 2004; Riccomini et al., 2007; Alvarenga et al., 2010) ao talude, permite inferir um período de intensa circulação termohalina, com um tempo de homogeneização intraoceânica igual ou inferior ao do tempo de residência do carbono na água do mar (1500 anos). Distribuição espacial semelhante é observada na base da Formação Doushantuo, na plataforma Yangtzé (China; Jiang et al., 2007; Zhu et al., 2007; McFadden et al., 2008; Ader et al., 2009), tendo sido interpretada igualmente como resultado de uma homogeneização isotópica do carbono inorgânico dissolvido na coluna d'água (Ader et al., 2009).

A raridade de afloramentos de carbonatos depositados após as glaciações Gaskiers e Serra Azul, apresentando anomalias negativas, não permitem a mesma interpretação sugerida para os carbonatos de capa marinoanos da Faixa Paraguai e Plataforma Yangtze. Além disso, sua ocorrência limitada e a dificuldade de correlação com a anomalia Wonoka-Shuram, de maior abrangência e registro geológico, sugerem a possibilidade de não representarem a composição da água do mar, ou de que as anomalias negativas não estejam conectadas às glaciações, mesmo a Marinoana 
(Halverson, 2006). No entanto, os carbonatos da Formação Serra Azul apresentam razões ${ }^{87} \mathrm{Sr} /{ }^{86} \mathrm{Sr}$ potencialmente primárias e coerentes com a evolução isotópica do $\mathrm{Sr}$ na água do mar para o mesmo período. Se a Formação Serra Azul for crono-correlata da Formação Gaskiers, estas anomalias podem estar relacionadas não só a este evento glacial, aparentemente de altas latitudes, mas também ao Impacto Acraman (Austrália, Gostin et al., 1986), de grandes dimensões e com idade estimada em cerca de $580 \mathrm{Ma}$ com base em acritarcas (Grey et al., 2003). Williams \& Wallace (2003) consideram que este impacto tenha sido catastrófico o suficiente para causar mudanças globais no meio-ambiente terrestre, que pode ser observado na mudança brusca da assembléia de acritarcas simples (leiosfera), abaixo da camada de ejetos de impacto, para uma assembléia de acritarcas grandes e complexos, acima dela (Calver \& Lindsay, 1998; Grey et al., 2003).

Variações de $\delta^{13} \mathrm{C}$ não relacionadas às glaciações

Nos carbonatos depositados entre as glaciações Marinoana e Gaskiers, tem-se encontrado diferentes evoluções isotópicas entre as bacias ediacaranas e mesmo dentro de uma única bacia, a exemplo da Formação Doushantuo (Ader et al., 2009; Li et al., 2010). Estas diferenças tem sido alvo de uma nova discussão sobre as condições biogeoquímicas reinantes nos oceanos ao longo do Ediacarano. $\mathrm{Na}$ Formação Doushantuo, amplas variações de $\delta^{13} \mathrm{C}$, observadas entre diferentes seções ao longo da plataforma, foram explicadas por um modelo de estratificação da coluna d'água. Ader et al. (2009), utilizando adicionalmente isótopos de carbono orgânico, sugerem a coexistência de ao menos três camadas para a plataforma interna: i) superficial oxigenada e homogênea (dolomitos com $\delta^{13} \mathrm{C}$ entre 0 a $7 \%$ ), ii) intermediária anóxica de mar profundo $\left(\delta^{13} \mathrm{C}\right.$ até $-10 \%$ ) e iii) metanogênica, mais profunda, restrita à plataforma interna e isolada do oceano aberto (valores de $\delta^{13} \mathrm{C}$ positivos).

Ao contrário do que se observa na Formação Doushantuo, a sucessão estudada apresenta apenas variações suaves nos valores de $\delta^{13} \mathrm{C}$, com clastos provenientes de ambientes mais rasos e depositados em ambiente de talude, mostrando uma diferença de redução de até $2,5 \%$ entre plataforma e talude. Quando este trabalho é contrastado com os demais realizados em sucessões plataformais e 
bacinais (Nogueira et al., 2003, 2007; Alvarenga et al., 2004, 2008; Riccomini et al., 2007), a diferença espacial entre os valores de $\delta^{13} \mathrm{C}$ se mantêm dentro do referido, com exceção do topo da Formação Nobres $\left(\delta^{13} \mathrm{C}\right.$ até $+9 \%$ em arenito dolomítico; e.g. Alvarenga et al., 2004), depositado em ambiente transicional, com maior influência de sedimentos terrígenos, bem como exposições e restrições periódicas. Estes resultados sugerem que a deposição ocorreu em um ambiente marinho com gradiente isotópico de carbono dissolvido semelhante ao atual. No entanto, a aplicação de ferramentas adicionais, que auxiliem na identificação das condições de oxi-redução da coluna d'água, se faz necessária para a confirmação de um mar homogêneo ou estratificado.

\section{CONCLUSÕES}

Este trabalho apresentou um estudo quimioestratigráfico criterioso e de alta resolução para as rochas carbonáticas da Faixa Paraguai. Os resultados mostraram que o estudo quimioestratigráfico das rochas ediacaranas requer cautela e rigor no uso de isótopos de carbono e estrôncio como ferramentas estratigráficas. No que diz respeito aos isótopos estáveis de carbono, observou-se uma variação de até 2,5\% ao longo da coluna d'água, que deve ser levada em consideração na correlação entre seções estratigráficas. Além disso, rochas não-metamórficas com alto teor de matéria orgânica, que tenham sofrido um aumento considerável de temperatura ou pressão durante a diagênese ou tectônica, podem apresentar carbonatos enriquecidos em ${ }^{12} \mathrm{C}$ por descarboxilação térmica. No tangente às razões ${ }^{87} \mathrm{Sr} /{ }^{86} \mathrm{Sr}$, estas se mostraram representativas da água do mar apenas em amostras com altos teores de $\mathrm{Sr}$ (acima de 300 ppm) e razões Sr/Ca superiores a 0,0010, além dos critérios já pré-estabelecidos na literatura, ou seja, razão $\mathrm{Mn} / \mathrm{Sr}$ menor que 0,5 e teores de $\mathrm{Mn}$ e Fe abaixo de 0,03 e 0,3\% (Denison et al., 1994), respectivamente. A utilização desses parâmetros químicos não tem sido observado em trabalhos quimioestratigráficos anteriores para a região, apresentando razões ${ }^{87} \mathrm{Sr} /{ }^{86} \mathrm{Sr}$ muito mais radiogênicas do que o esperado e inviabilizando as correlações estratigráficas através de desta ferramenta.

Os carbonatos da Faixa Paraguai apresentaram duas anomalias negativas de $\delta^{13} \mathrm{C}$ associadas ao fim de dois eventos glaciais, o mais antigo representado pela Formação Puga (- 5\%) e o mais novo pela Formação Serra Azul (- 7\%). As razões 
${ }^{87} \mathrm{Sr} /{ }^{86} \mathrm{Sr}$ obtidas corroboram com a correlação destes com as glaciações Marinoana e Gaskiers, respectivamente. A anomalia mais antiga pode ser observada ao longo de toda a bacia, mostrando um período de extrema homogeneização intraoceânica dos isótopos de carbono. Os carbonatos com $\delta^{13} \mathrm{C}$ não-anômalos apresentaram valores predominantemente negativos (entre $0 \mathrm{e}-3 \%$ ), ocorrendo valores positivos (até $+2 \%$ ) nos dolomitos bioconstruídos da Formação Nobres. A comparação das seções estudadas com as demais disponíveis na literatura (Alvarenga et al., 2004, 2008, 2010; Figueiredo, 2006; Nogueira et al., 2003, 2007; Riccomini et al., 2007) mostrou uma variação nos valores de $\delta^{13} \mathrm{C}$ não superiores a $3 \%$, exceto para os ambientes de transição que ocorrem no topo da Formação Nobres, onde as diferenças chegam a $5 \%$. Esta variação é próxima do encontrado em plataformas marinhas atuais e se contrapõe às grandes variações encontradas para a Formação Doushantuo (até 15\%) ao longo da plataforma, tidas como resultado de uma coluna d'água fortemente estratificada (Ader et al., 2009). No entanto, a quimioestratigrafia da Faixa Paraguai ainda possui baixa resolução de amostragem para os dolomitos e poucos dados ao longo da bacia, carecendo de mais estudos que sigam os critérios químicos de seleção de amostras, para que os resultados possam ser usados com maior segurança em correlações intra-bacinais e globais.

\section{REFERENCES}

Almeida, F.F.M. 1964. Geologia do Centro-Oeste matogrossense. Rio de Janeiro, DNPM, Boletim 215, 1-53 p.

Ader, M., Macouin, M., Trindade, R.I.F., Hadrien, M-H., Yang, Z., Sun, Z., Besse, J. 2009. A multilayered water column in the Ediacaran Yangtze platform? Insights from carbonate and organic matter paired $\delta^{13} \mathrm{C}$. Earth and Planetary Science Letters, 288: 213-227.

Alvarenga, C.J.S., Santos, R.V., Dantas, E.L. 2004. C-O-Sr isotopic stratigraphy of cap carbonates overlying Marinoan-age glacial diamictites in the Paraguay Belt, Brazil. Precambrian Research, 131: 1-21.

Alvarenga, C.J.S., Dardenne, M.A., Santos, R.V., Brod, E.R., Gioia, S.M.C.L., Sial, A.N., Dantas E.L., Ferreira, V.P. 2008. Isotope stratigraphy of Neoproterozoic cap carbonates in the Araras Group, Brazil. Gondwana Research, 13: 469-479. 
Asmerom, Y., Jacobsen, S.B., Knoll, A.H., Butterfield, N.J., Swett, K., 1991. Strontium isotopic variations of Neoproterozoic seawater: Implications for crustal evolution. Geochimica et Cosmochimica Acta, 55: 2883-2894.

Brand, U., Veizer, J. 1980. Chemical diagenesis of a multicomponent carbonate system - 1: trace elements. Journal of Sedimentary Petrology, 50: 1219-1236.

Banner, J.L., 2004. Radiogenic isotopes: systematics and applications to Earth surface processes and chemical stratigraphy. Earth-Science Reviews, 65:141-194.

Bingen, B., Griffin, W.L., Torsvik, T.H., Saeed, A. 2005. Timing of late Neoproterozoic glaciation on Baltica constrained by detrital geochronology in the Hedmark Group, southeast Norway. Terra Nova ,17: 593-596.

Broecker, W.S., Peng, T.S. 1982. Tracers in the sea. Eldio Press, New York, 690p.

Calver, C.R., Lindsay, J.F. 1998. Ediacaran sequence and isotope stratigraphy of the Officer Basin, South Australia. Australian Journal of Earth Science, 45:513-532.

Calver, C.R., 2000. Isotope stratigraphy of the Ediacaran (Neoproterozoic III) of Adelaide Rift Complex, Austrália, and the overprint of water column stratification. Precambrian Research, 100: 121-150.

Christie-Blick, N., Dyson, I.A., Von der Borch, C.C. 1995. Sequence stratigraphy and the interpretation of Neoproterozoic Earth history. Precambrian Research, 73: 3-26.

Condon, D., Zhu, M., Bowring, S., Jin, Y., Wang, W., Yang, A., 2005. From the Marinoan glaciation to the oldest bilaterians: $\mathrm{U}-\mathrm{Pb}$ ages from the Doushantuo Formation, China. Science, 308: 95-98.

Condon, D.J., Prave, A.R. 2000. Two from Donegal: Neoproterozoic glacial episodes on the northeast margin of Laurentia. Geology, 28: 951-954.

Dempster, T.J., Rogers, G., Tanner, P.W.G., Bluck, B.J., Muir, R.J., Redwood, S.D., Ireland, T.R., Patterson, B.A. 2002. Timing of deposition, orogenesis and glaciation within the Dalradian rocks of Scotland: constraints from U-Pb zircon ages. Journal of Geological Society, London, 159: 83-84.

Denison, R.E., Koepnick, R.B., Fletcher, A., Howell, M.W., Callaway, W.S. 1994. Criteria for the retention of original seawater ${ }^{87} \mathrm{Sr} /{ }^{86} \mathrm{Sr}$ in ancient shelf limestone. Chemical Geology, 112:131-143.

Derry, L.A., Kaufman, A.J., Jacobsen, S.B. 1992. Sedimentary cycling and environmental change in the Late Proterozoic: evidence from stable and radiogenic isotopes. Geochimica et Cosmochimica Acta, 56:1317-1329. 
Elderfield H., Greaves M.J. 1982. The rare-earth elements in sea-water. Nature, 296: 214-219

Figueiredo, M.F., Babinski, M., Alvarenga, C.J.S., Pinho, F.E.C. 2008. Nova unidade litoestratigráfica registra glaciação Edicarana em Mato Grosso: Formação Serra Azul. Geologia-USP, 8: 65-75.

Fike D.A., Grotzinger J.P., Pratt L.M., Summons R.E. 2006. Oxidation of the Ediacaran Ocean. Nature, 444: 744-747.

Fairchild, I., Kennedy, M.J. 2007. Neoproterozoic glaciation in the Earth System. Journal of the Geological Society, London, 164: 895-921.

Font E., Nédélec A., Trindade R.I.F., Macouin, M., A. Charrière. 2006. Chemostratigraphy of the Neoproterozoic Mirassol d'Oeste cap dolostones (Mato Grosso, Brazil): implications for the Snowball Earth aftermath. Earth and Planetary Sciences Letters, 250: 89-103.

Gostin, V.A., Haines, P.W., Jenkins, R.J.F., Compston, W. 1986. Impact ejecta horizon within late Precambrian shales, Adelaide geosyncline, South Australia. Science 233: $542-544$.

Grey, K., Walter, M.R., Calver, C.R. 2003. Neoproterozoic biotic diversification: Snowball Earth or aftermath of the Acraman impact. Geology, 31:459-462.

Grotzinger, J.P., Knoll, A.H.. 1995. Anomalous carbonate precipitates: Is the Precambrian the key to the Permian? Palaios,10: 578-596.

Halverson, G.P., Hoffman, P.F., Schrag, D.P., Maloof, A.C., Rice, A.H. 2005. Towards a Neoproterozoic composite carbon-isotope record. Geological Society of America Bulletin, 117: 1181-1207.

Halverson, G.P. 2006. A Neoproterozoic chronology. In: Xiao,S., Kaufman,A.J. (Eds.), Neoproterozoic Geobiology and Paleobiology. Springer, pp. 231-271.

Halverson, G.P., Dudas, F.O., Maloof, A.C., Bowring, S.A. 2007. Evolution of the ${ }^{87} \mathrm{Sr} /{ }^{86} \mathrm{Sr}$ composition of Neoproterozoic seawater. Palaeogeography, Palaeoclimatology, Palaeoecology, 256:103-129.

Hoffman, P.F., Kaufman, A.J., Halverson, G.P., Schrag, D.P. 1998. A Neoproterozoic Snowball Earth. Science, 281: 1342-1346.

Jacobsen, S., Kaufman, A., 1999. The Sr, C and O isotopic evolution of the Neoproterozoic seawater. Chemical Geology, 161: 37-57. 
Jiang, G., Sohl, L.E., Christie-Blick, N. 2003. Neoproteroozic stratigraphic comparison of the Lesser Himalaya (India) and Yangtze block (south China): Paleogeographic implications. Geology, 31: 917-920.

Jiang, G., Kaufman, A.J., Christie-Blick, N., Zhang, S., Wu, H. 2007. Carbon isotope variability across the Ediacaran Yangtze platform in South China: implications for a large surface-to-deep ocean $\delta^{13} \mathrm{C}$ gradient. Earth Planetary and Science Letters. 261: 303-320.

Jorgensen, B.B. 1982. Mineralization of organic matter in the sea bed - the role of sulphate reduction. Nature, 296: 643-645.

Kaufman, A.J., Knoll, A.H., 1995. Neoproterozoic variations in the C-isotopic composicional of seawater: Stratigraphic and biogeochemical implications. Precambrian Research, 73: 27-49.

Kaufman, A.J., Jacobsen, S.B., Knoll, A.H., 1993. The Vendian record of Sr- and Cisotopic variations in seawater: implications for tectonics and paleoclimate. Earth and Planetary Science Letters, 120: 409-430.

Kennedy, M.J. 1996. Stratigraphy, sedimentology, and isotopic geochemistry of Australian Neoproterozoic postglacial cap dolostones: Deglaciation, C excursions, and carbonate precipitation. Journal of Sedimentary Research, 66: 1050-1064.

Kennedy, M.J., Christie-Blick, N., Sohl, L.E., 2001. Are Proterozoic cap carbonates and isotopic excursions a record of gas hydrate destabilization following Earth's coldest intervals? Geology, 29: 443-446.

Kroopnik, P. 1980. The distribution of ${ }^{13} \mathrm{C}$ in the Atlantic Ocean. Earth and Planetary Science Letters, 30: 469-484.

Le Guerroue, E., Allen, P.A., Cozzi A. 2006. Chemostratigraphic and sedimentological framework of the largest negative carbon isotopic excursion in Earth history: the Neoproterozoic Shuram Formation (Nafun Group, Oman). Precambrian Research, 146: 68-92.

Li, C., Love, G.D., Lyons, T.W., Fike, D.A., Sessions, A.L., Chu, X. 2010. A stratified redox model for the Ediacaran ocean. Science, 328: 80-83.

McFadden, K.A., Huang, J., Chu, X., Jiang, G., Kaufman, A.J., Zhou, C., Yuan, X., Xiao, S. 2008. Pulsed oxidation and biological evolution in the Ediacaran Doushantuo Formation. PNAS, 105: 3197-3202.

Meert, J.G., Van der Voo, R. 1997. The assembly of Gondwana 800 - 550 Ma. Journal of Geodynamics, 23: 223-235. 
Myrow, P.M., Kaufman, A.J. 1999. A newly discovered cap carbonate above Varangerage glacial deposits in Newfoundland, Canada. Journal of Sedimentary Research, 69: 784-793.

Newton, R., Bottrell,S. 2007. Stable isotopes of carbon and sulphur as indicators of environmental change: past and present. Journal of the Geological Society, London, 164: 691-708.

Nogueira, A.C.R., Riccomini, C., Sial, A.N., Moura, C.A.V., Fairchild, T.R. 2003. Softsediment deformation at the base of the Neoproterozoic Puga cap carbonate (southwestern Amazon craton, Brazil): Confirmation of rapid icehouse to greenhouse transition in snowball Earth. Geology, 31: 613-616.

Nogueira, A.C.R., Riccomini, C. 2006. O Grupo Araras da Faixa Paraguai Norte, Sul do Cráton Amazônico. Revista Brasileira de Geociências, 36: 623-640.

Nogueira, A.C.R., Riccomini, C., Sial, A.N., Moura, C.A.V., Trindade, R.I.F., Fairchild, T.R., 2007. Carbon and strontium isotope fluctuations and paleoceanographic changes in the late Neoproterozoic Araras carbonate platform, southern Amazon craton, Brazil. Chemical Geology, 237: 168-190.

Riccomini, C., Nogueira, A.C.R., Sial, A.N. 2007. Carbon and oxygen isotope geochemistry of Ediacaran outer platform carbonates, Paraguay Belt, central Brazil. Anais da Academia Brasileira de Ciências, 79: 519-527.

Sawaki, Y., Ohno, T., Tahata, M., Komiya, T., Hirata, T., Maruyama, S., Windley, B.F., Han, J., Shud, D., Li, Y. 2010. The Ediacaran radiogenic Sr isotope excursion in the Doushantuo Formation in the Three Gorges area, South China. Precambrian Research, 176: 46-64.

Silva Júnior, J.C., Nogueira, A.C.R., Petri, S., Riccomini, C., Trindade, R.I.F., Sial, A.N., Hidalgo, R.L. 2007. Depósitos litorâneos neoproterozóicos do Grupo Alto Paraguai no sudoeste do Cráton Amazônico, região de Mirassol d'Oeste, Mato Grosso. Revista Brasileira de Geociências, 37: 595-606.

Thompson, M.D., Bowring, S.A. 2000. Age of the Squantum 'tillite', Boston basin, Massachusetts: U-Pb zircon constraints on terminal Neoproterozoic glaciation. American Journal of Science, 300: 630-655.

Trindade, R.I.F., Font, E., D’Agrella-Filho, M.S., Nogueira, A.C.R., Riccomini, C. 2003. Low-latitude and multiple geomagnetic reversals in the Neoproterozoic Puga cap carbonate, Amazon craton. Terra Nova, 15:441-446. 
Williams, G.E., Wallace, M.W., 2003. The Acraman asteroid impact, South Australia: magnitude and implications for late Vendian environment. Journal of Geological Society, London, 160: 545-554.

Veizer, J., Compston, W., Clauer, N., Schidlowski, M., $1983 .{ }^{87} \mathrm{Sr} /{ }^{86} \mathrm{Sr}$ in Late Proterozoic carbonates: Evidence for a mantle event at $900 \mathrm{Ma}$ ago. Geochimica et Cosmochimica Acta, 47: 295-302.

Xiao, S., Bao, H., Wang, H., Kaufman, A.J., Zhou, C., Li, G., Yuan, X., Ling, H. 2004. The Neoproterozoic Quruqtagh Group in eastern Chinese Tianshan: evidence for a post-Marinoan glaciation. Precambrian Research 130: 1-26.

Zhu, M., Zhang, J., Yang, A., 2007. Integrated Ediacaran (Sinian) chronostratigraphy of South China. Palaeogeography, Palaeoclimatology, Palaeoecology, 254: 7-61.

\subsection{ARTIGO 3: ABUNDÂNCIA ISOTÓPICA ANÔMALA DE ENXOFRE PESADO NOS CARBONATOS EDIACARANOS DA FAIXA PARAGUAI NORTE.}

Milene F. Figueiredo ${ }^{1}$, Alan J. Kaufman ${ }^{2}$, Marly Babinski ${ }^{1}$

1 - Instituto de Geociências, Universidade de São Paulo (USP), São Paulo, SP - Brazil.

2 - Geology Department, University of Maryland (UMD), College Park, MD - USA.

E-mail: milene.figueiredo@gmail.com, kaufman@geol.umd.edu, babinski@usp.br

\section{RESUMO}

Dados isotópicos recentes adquiridos em rochas carbonáticas de Oman, Newfoundland, leste dos Estados Unidos e sudeste da China têm sugerido uma progressiva redução do reservatório de matéria orgânica dissolvida e aumento do reservatório de sulfato dissolvido, como conseqüência de uma oxigenação prolongada do oceano no Ediacarano. No entanto, alguns trabalhos têm encontrado evidências de coexistência de ambientes anóxicos e euxínicos nas seções da plataforma Yangtze (China), sugerindo modelos alternativos de estratificação dos oceanos ediacaranos. 
Neste trabalho, serão apresentados dados isotópicos de carbono e enxofre anômalos para as seções carbonáticas da Faixa Paraguai, cujos valores de $\delta^{34} S$ chegam a + $62 \%$ nos sulfatos e $+43 \%$ nos sulfetos, enquanto que os valores de $\delta^{13} \mathrm{C}$ variam de 35 a - 18\%o na matéria orgânica e de - 6 a + 2\%o nos carbonatos. Estes dados apontam para condições ambientais anóxicas e com um reservatório restrito de sulfato dissolvido. Os valores anomalamente pesados de $\delta^{34} S$ observados da Faixa Paraguai tornam a correlação com as demais seções ediacaranas mais complexa, podendo evidenciar ambientes distintos entre elas.

\section{INTRODUÇÃO}

O ciclo biogeoquímico do enxofre está intimamente ligado a uma variedade de processos que redistribuem seus isótopos entre diversos reservatórios superficiais, incluindo os íons $\mathrm{SO}_{4}{ }^{2-}$ e $\mathrm{HS}^{-}$dissolvidos na água do mar e os minerais precipitados como sulfatos e sulfetos (Figura 1). No estudo de ambientes antigos, a abundância e a composição isotópica de sulfato mineral, presente como evaporitos ou como sulfato associado a carbonatos (CAS: Carbonate Associated Sulfate; i.e. sulfato estruturalmente aprisionado em carbonatos), e sulfetos (CRS: Chromium Reductible Sulfide), presente como pirita, são geralmente analisados. O maior mecanismo de fracionamento está associado com a redução biológica de sulfatos (BSR: Biological Sulfate Reduction), onde o sulfato é utilizado na respiração dos organismos, resultando na produção de $\mathrm{HS}^{-}$rico em ${ }^{32} \mathrm{~S}$ e de $\mathrm{CO}_{2}$ rico em ${ }^{12} \mathrm{C}$. Enquanto a maior parte do sulfeto é reoxidado em sulfato (Jorgensen, 1982; Canfield et al., 1991), parte é seqüestrada para os sedimentos pela reação com ferro disponível, formando pirita (Lin \& Morse, 1991) ou S ligado à matéria orgânica (OBS: Organically Bound Sulfur; e.g. em compostos polares; Sinninghe Damste \& de Leeuw, 1990). O enxofre também é removido dos oceanos através da evaporação, o que resulta na precipitação de minerais de sulfato em ambientes rasos com pequeno fracionamento isotópico. As fontes do enxofre oceânico incluem as descargas fluviais, contendo uma mistura de sulfetos e sulfatos intemperisados vindos do continente, e gases vulcânicos. Ambas as fontes são empobrecidas em ${ }^{34} \mathrm{~S}$ relativo ao sulfato dissolvido na água do mar (Newton \& Bottrell, 2007). 


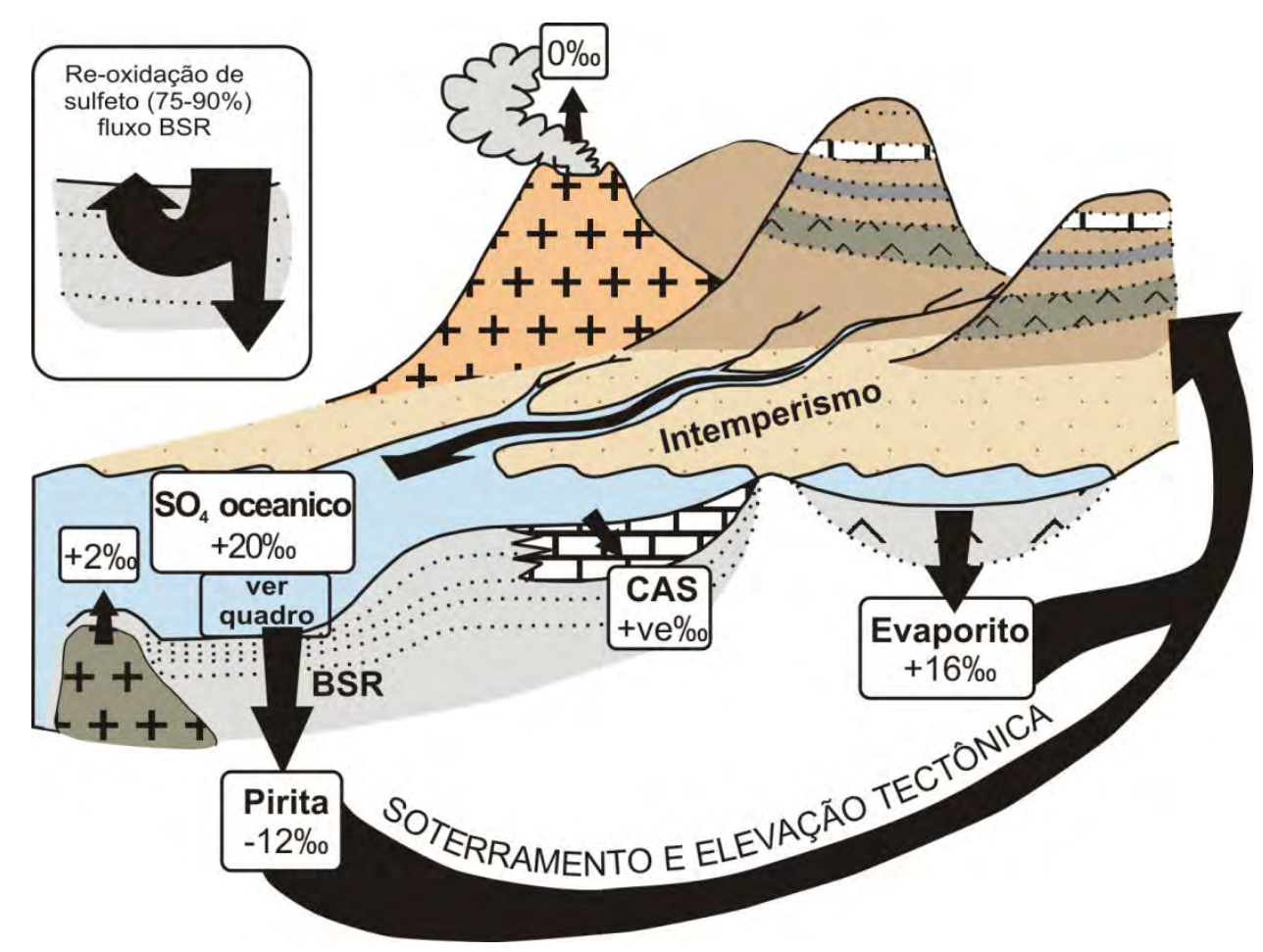

Figura 1. llustração esquemática do ciclo global do enxofre (modificado de Newton \& Botrell, 2007). CAS: sulfato associado ao carbonato; BRS: redução biológica do sulfato.

Estudos recentes utilizando isótopos de enxofre em carbonatos Ediacaranos ao redor do mundo têm mostrado que a magnitude de fracionamento entre os reservatórios oxidados (sulfatos) e reduzidos (sulfetos) parece aumentar em direção ao limite Precambriano-Cambriano, especialmente após o evento conhecido como Shuram (McFadden et al., 2008). Esta anomalia biogeoquímica está registrada em sucessões ao redor do mundo como uma forte incursão negativa nos isótopos de carbono (até 10\%o ou menos), mas não está atualmente relacionada com uma era do gelo. Ela pode estar relacionada à oxidação de um amplo reservatório de carbono orgânico dissolvido na água do mar ediacarano, que seria empobrecido à medida que o ambiente fosse oxidado (McFadden et al., 2008).

Com o objetivo de contribuir no entendimento das causas das anomalias isotópicas de $\delta^{13} \mathrm{C}$ e a evolução da água do mar no fim do Neoproterozoico, este estudo apresenta também dados isotópicos de enxofre e carbono orgânico obtidos nos carbonatos ediacaranos da Faixa Paraguai, depositados entre a Glaciação Marinoana (ca. $635 \mathrm{Ma}$ ) e o evento Wonoka-Shuram (longa anomalia negativa de $\delta^{13} \mathrm{C}$ anterior há $551 \mathrm{Ma})$. 


\section{CONTEXTO GEOLÓGICO}

A Faixa Paraguai está localizada na borda sudeste do Craton Amazônico (Figura 2) e é composta de rochas sedimentares marinhas, que foram depositadas em uma margem continental passiva e posteriormente deformadas durante a Orogenia Brasiliana. A base da Faixa Paraguai é representada pelo Grupo Cuiabá, que comporta, da base para o topo, folhelho rico em matéria orgânica, dolomito, diamictito, rudito e arenito intercalado com folhelho, interpretados como de ambiente marinho a tglácio-marinho (Alvarenga \& Trompette, 1992). Lateralmente, o topo deste grupo grada para a Formação Puga, que é composta por diamictitos interpretados como de origem glacial. Esta formação tem sido correlacionada à Glaciação Marinoana, com base na quimioestratigrafia isotópica de carbono e estrôncio dos carbonatos pós-glaciais (Nogueira et al., 2003; Alvarenga et al., 2004).

O diamictito Puga é imediatamente sobreposto pelos carbonatos do Grupo Araras, o qual é dividido em quatro formações, em ordem ascendente: Mirassol d'Oeste, Guia, Serra do Quilombo e Nobres (Nogueira \& Riccomini, 2006). A Formação Mirassol d'Oeste é composta de dolomito de capa róseo (ca. $30 \mathrm{~m}$ ) caracterizado por estromatólitos, leques de crisais de aragonita e barita, tubestones e mega ripples (Nogueira et al., 2003). A Formação Guia compreende calcário laminado, marga e brecha carbonática (ca. $250 \mathrm{~m}$ ), depositados em ambientes de plataforma profunda e talude. A Formação Serra do Quilombo é composta por dolomitos laminado e brechas (Nogueira \& Riccomini, 2006), não tendo sido reconhecida na nossa área de estudo. A Formação Nobres (<800 m) é composta por dolomitos contendo diversas fácies de plataforma rasa e planície de maré.

O Grupo Araras é sobreposto pela Formação Serra Azul, de maneira descontínua ao longo da bacia (Figueiredo et al., 2008). Esta formação contém, da base para o topo, diamictito (ca. $70 \mathrm{~m}$ ), siltito laminado vermelho e argilito cinza (> 70 $\mathrm{m})$, com intercalações de arenito fino com laminação plano paralela ou truncada por onda (hummocky) para o topo (Alvarenga et al., 2007, Figueiredo et al., 2008). Em um afloramento ocorre uma camada de calcário lenticular (7-9 m) no topo do siltito vermelho, constituída por calcário puro laminado e brechas, ocorrendo dobras sedimentares e pseudomorfos de aragonita. A Formação Serra Azul grada para os arenitos, arcóseos e ruditos da Formação Raizama. 


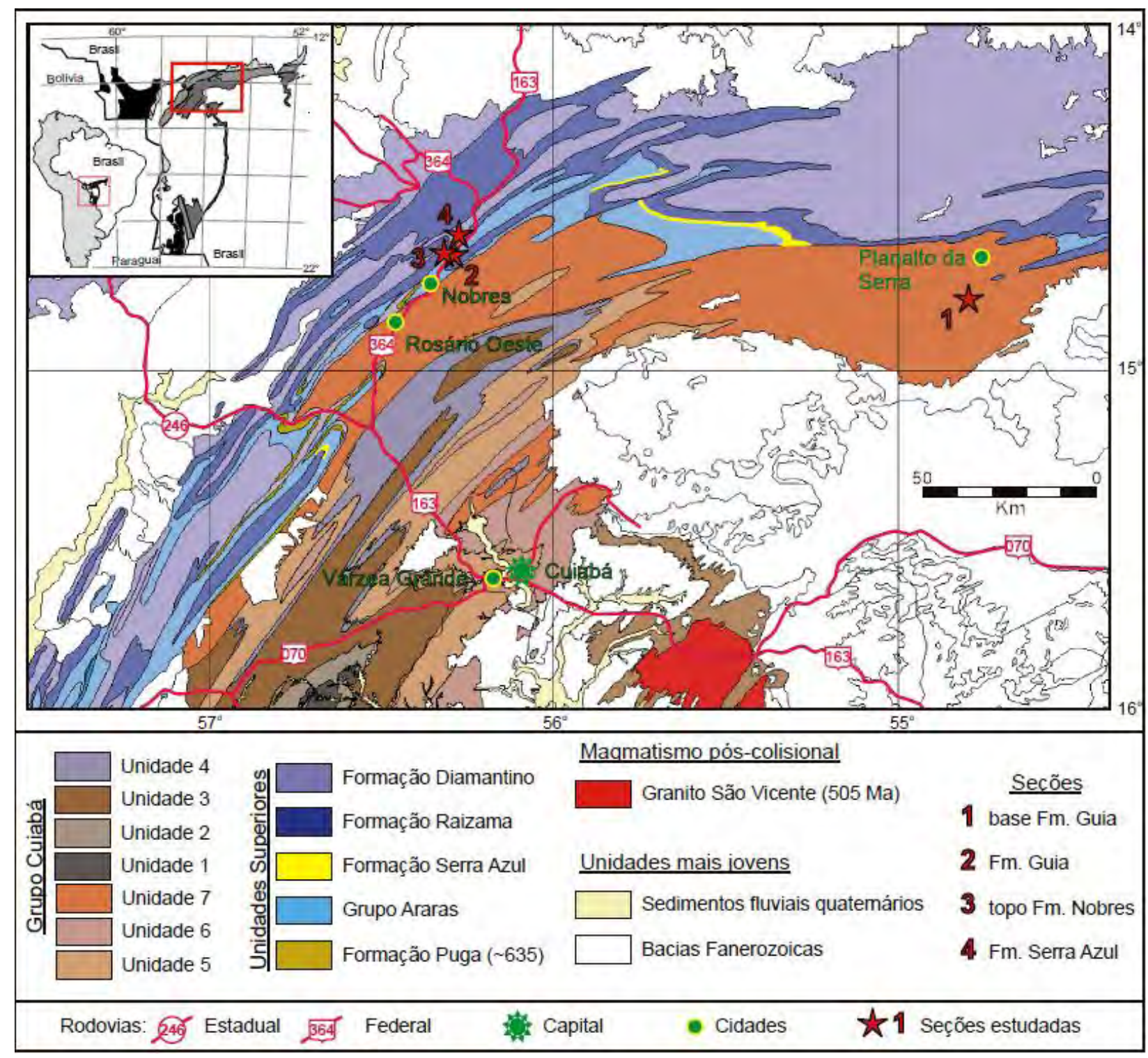

Figura 2. Mapa geológico da Faixa Paraguai Norte (modificado de Schobenhaus et al., 2003), com a localização das seções estudadas.

\section{PROCEDIMENTO ANALÍTICO}

O enxofre foi extraído das rochas carbonáticas como sulfato associado a carbonato (CAS: carbonate associated sulfate) e sulfeto redutível por cromo (CRS: chromium reductible sulfide). Para obtenção do CAS, ao menos $200 \mathrm{~g}$ de rocha pulverizada foi lixiviada com $2 \mathrm{~L}$ de $\mathrm{NaCl}(10 \%)$ por $24 \mathrm{~h}$, filtrada em filtros de papel e de membrana de nitrato de celulose de 0,45 $\mu \mathrm{m}$ para remoção dos sólidos, e $30 \mathrm{ml}$ de $\mathrm{BaCl}(8 \%)$ foram adicionadas ao lixiviado para precipitar $\mathrm{BaSO}_{4}$. Este processo foi repetido até 5 vezes ou até nenhum precipitado de $\mathrm{BaSO}_{4}$ ser observado no lixiviado. 
Estes precipitados de $\mathrm{BaSO}_{4}$ estão associados com sulfatos não aprisionados pela estrutura dos carbonatos ou sulfetos oxidados e são, portanto, de provável origem diagenética. Após o lixiviado, o resíduo sólido foi acidificado com $\mathrm{HCl}(27 \%)$ por gotejamento sobre a amostra colocada dentro de funil com filtro de papel sobre um béquer, com a finalidade de evitar um contato prolongado com a pirita presente na amostra (Marenco et al., 2008), separar a fração não-carbonática e coletar a solução final. Esta solução foi primeiramente filtrada com filtro de membrana de nitrato de celulose $0,45 \mu \mathrm{m}$ e então $30 \mathrm{ml}$ de $\mathrm{BaCl}(8 \%)$ foram adicionados à solução ácida e deixada reagir por $24 \mathrm{~h}$. Estes precipitados de $\mathrm{BaSO}_{4}$, considerados como a fração CAS, foram coletados por filtragem com membrana de nitrato de celulose 0,45 $\mu \mathrm{m}$, lavados e secos.

Para a extração do CRS, $5 \mathrm{~g}$ de amostra pulverizada (carbonato ou pelito) foram acidificados com $\mathrm{HCl} 3 \mathrm{M}$ em um funil de Bückner, com filtro de papel, sob vácuo para minimizar o tempo de exposição dos sulfetos ao ácido durante a remoção dos carbonatos. O resíduo foi lavado com água Milli-Q, seco e, então, atacado com $25 \mathrm{ml}$ de $\mathrm{CrCl}_{2} 1 \mathrm{M}$. O HS liberado na reação foi transferido através de um fluxo de $\mathrm{N}_{2}$ até uma solução armadilha de $\mathrm{AgNO}_{3}$ 0,3 M, ácida, onde foi convertido em $\mathrm{Ag}_{2} \mathrm{~S}$ insolúvel. Os precipitados foram envelhecidos por, ao menos, 2 dias em ambiente escuro, filtrados e lavados com hidróxido de amônia, água Milli-Q e secos.

Os extratos de $\mathrm{BaSO}_{4}$ e $\mathrm{Ag}_{2} \mathrm{~S}$ foram pesados ( $\left.150 \mu \mathrm{g}\right)$ em cadinhos de estanho com um excesso de $\mathrm{V}_{2} \mathrm{O}_{5}$ (1:3) para combustão em $\mathrm{SO}_{2}$ em um analisador Elemental Eurovector, acoplado a um espectrômetro de massas GV Isoprime. Os valores $\delta^{34} S$ são

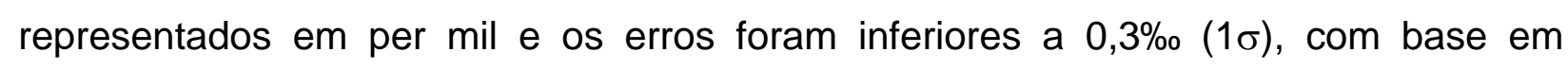
determinações realizadas no padrão NBS 127.

\section{RESULTADOS}

Os resultados das análises isotópicas realizadas nos carbonatos da Faixa Paraguai estão demonstrados na Tabela 1 e representados estratigraficamente na Figura 2. Foram analisadas 123 amostras de quatro seções, correspondentes à base e metade superior da Formação Guia (seções 1 e 2, respectivamente, Figuras 2 e 3), ao topo da Formação Nobres (seção 3, Figuras 2 e 3) e à porção intermediária da 
Formação Serra Azul (seção 4, Figuras 2 e 3). Os carbonatos das seções 1 e 4, depositados imediatamente depois dos diamictitos glaciais das formações Puga e Serra Azul, forneceram valores de $\delta^{13} \mathrm{C}_{\text {(carb) }}$ fortemente negativos de até -6 e $-7 \%$, respectivamente. A matéria orgânica, presente nas amostras da seção 1, apresentou valores de $\delta^{13} \mathrm{C}_{\text {(org) }}$ de cerca de $30 \%$, enquanto que a seção 4 não forneceu matéria orgânica suficiente para análise. Ambas as seções 1 e 4 também não forneceram CAS, sendo que os lixiviados obtidos para a seção 1 apresentaram $\delta^{34} S_{(\text {(ix) }}$ entre 26 e 30\%o (Figura 2). Os sulfetos presentes nestas duas seções mostraram $\delta^{34} \mathrm{~S}_{\text {(CRS) }}$ entre $28 \mathrm{e}$ 35\% para a base da Formação Guia (seção 1) e entre 15 e 28\% para a Formação Serra Azul (seção 4).

A sucessão de topo da Formação Guia (seção 2, Figura 2) apresentou valores de $\delta^{13} \mathrm{C}_{\text {(carb) }}$ negativos entre $-0,2$ e $-3 \%$ enquanto que os valores de $\delta^{13} \mathrm{C}_{\text {(org) }}$ obtidos na matéria orgânica variam entre -30 e $-35 \%$ (seção 2, Figura 3). Os sulfatos extraídos da estrutura dos minerais carbonáticos apresentam valores $\delta^{34} S_{(\text {CAS })}$ entre 41 e 61\%, com tendência crescente para o topo (seção 2, Figura 3). Os lixiviados das mesmas amostras mostraram valores de $\delta^{34} S_{(\text {lix) }}$ mais leves que os CAS, entre $17 \mathrm{e}$ $50 \%$ (seção 2, Figura 3 e Figura 4). Os sulfetos presentes forneceram valores $\delta^{34} S_{\text {(CRS) }}$ entre 11 e 43\%o (seção 2, Figura 3).

Os carbonatos da sucessão de topo da Formação Nobres (seção 3, Figura 2) forneceram valores de $\delta^{13} \mathrm{C}_{\text {(carb) }}$ entre $+0,3$ e $-2 \%$, com predomínio dos valores ao redor de $0 \%$, enquanto que a matéria orgânica apresentou valores de $\delta^{13} \mathrm{C}_{(\text {org) }}$ entre 16 e - 33\%. Esta seção apresentou CAS com valores $\delta^{34} S_{(C A S)}$ entre 22 e 60\%, enquanto que os lixiviados apresentaram valores de $\delta^{34} S_{(\text {lix) }}$ variando entre 14 e $33 \%$ (seção 3, Figura 2), predominantemente mais leves que os valores apresentados pelo CAS (Figura 3). Os valores de $\delta^{34} S_{\text {(CRS) }}$ obtidos nos sulfetos variam entre 17 e $42 \%$, com tendência crescente para o topo (seção 3, Figura 3). 
Tabela 1.Resultados das análises isotópicas de C e S para as frações oxidadas e reduzidas e de S para os lixiviados.

\begin{tabular}{|c|c|c|c|c|c|c|c|c|c|c|c|c|c|c|c|c|}
\hline & metros & amostra & rocha & $\begin{array}{c}\delta^{34} S \\
\text { (CRS) }\end{array}$ & CAS & Lix 1 & $\begin{array}{r}\delta^{3} \\
\text { Lix } 2 \\
\end{array}$ & $\begin{array}{l}{ }^{4} S \\
\text { Lix } 3\end{array}$ & Lix 4 & Lix 5 & $\Delta^{34} S$ & $\begin{array}{l}\delta^{13} \mathrm{C} \\
\text { (Org) }\end{array}$ & $\begin{array}{c}\delta^{13} \mathrm{C} \\
\text { (Carb) }\end{array}$ & $\Delta^{13} \mathrm{C}$ & $\delta^{18} \mathrm{O}$ & ${ }^{87} \mathrm{Sr} r^{86} \mathrm{Sr}$ \\
\hline & 53 & PS-1 & Dolomito & & & & & & & & & & -0.4 & & -4.1 & \\
\hline & 52 & PS-2 & Dolomito & & & & & & & & & & -1.1 & & -6.1 & \\
\hline & 51 & PS-3 & Dolomito & & & & & & & & & & -1.0 & & -4.8 & \\
\hline & 0.2 & PS43 & Dolomito & 30.0 & & & 29.3 & & & & & & -5.6 & & -7.1 & \\
\hline & 0.4 & PS44 & Dolomito & & & & & & & & & & -5.1 & & -8.2 & \\
\hline & 0.4 & PS45 & Dolomito & 34.7 & & & & & & & & & -5.3 & & -7.3 & \\
\hline & 0.8 & PS46 & Dolomito & 36.9 & & 30.7 & & & & & & & -5.2 & & -7.6 & \\
\hline & 1.2 & PS47b & Dolomito & 30.3 & & & & & & & & & -6.3 & & -7.8 & \\
\hline & 1.2 & PS47a & Dolomito & & & & & & & & & & -3.5 & & -6.1 & \\
\hline & 1.6 & PS48 & Dolomito & 28.1 & & & & & & & & & -4.4 & & -7.8 & \\
\hline & 2.5 & PS49 & Dolomito & & & & & & & & & & -4.7 & & -7.6 & 0.7081 \\
\hline & 3.2 & PS50 & Dolomito & 28.2 & & 25.9 & & & & & & -29.6 & -4.2 & 25.5 & -8.1 & \\
\hline & 6.7 & PS51 & Dolomito & 34.9 & & & & & & & & -30.0 & -5.5 & 24.6 & -6.9 & \\
\hline & 0.0 & Co01a & Calcário & & & & & & & & & & -0.5 & & -7.5 & \\
\hline & 0.0 & CO01b & Calcário & & & & & & & & & & -0.2 & & -7.2 & \\
\hline & 0.0 & co01c & Calcário & & & & & & & & & & -0.4 & & -7.3 & \\
\hline & 1.0 & $\mathrm{CO} 2$ & Calcário & 43.4 & & & & & & & & -31.0 & -0.2 & 30.7 & -6.8 & \\
\hline & 2.0 & $\mathrm{COO3}$ & Calcário & & & & & & & & & & & & & \\
\hline & 3.0 & COO4 & Calcário & & & & & & & & & & & & & \\
\hline & 4.0 & CO05 & Calcário & & & & & & & & & & & & & \\
\hline & 5.0 & CO06 & Calcário & 23.3 & & 50.8 & 45.5 & & & & & & -0.6 & & -6.9 & 0.7076 \\
\hline & 6.0 & $\mathrm{CO} 07$ & Calcário & & & & & & & & & & & & & \\
\hline & 7.0 & $\mathrm{CO08}$ & Calcário & & & & & & & & & & & & & \\
\hline & 8.0 & CO09 & Calcário & & & & & & & & & & & & & \\
\hline & 9.0 & CO10 & Calcário & 17.6 & & & & & & & & -29.7 & -1.1 & 28.6 & -7.6 & \\
\hline & 10.0 & CO11 & Calcário & & & & & & & & & & & & & \\
\hline & 11.0 & CO12 & Calcário & & & & & & & & & & & & & \\
\hline & 12.0 & $\mathrm{CO} 13$ & Calcário & & & & & & & & & & & & & \\
\hline & 13.0 & CO14 & Calcário & 11.2 & & & & & & & & & -0.7 & & -7.1 & \\
\hline & 14.0 & CO15 & Calcário & & & & & & & & & & & & & \\
\hline & 15.0 & CO16 & Calcário & & & & & & & & & & & & & \\
\hline & 16.0 & CO17 & Calcário & & & & & & & & & & & & & \\
\hline & 17.0 & CO18 & Calcário & 13.7 & 41.0 & 18.7 & & & & & 27.3 & & -0.8 & & -6.6 & \\
\hline & 18.0 & CO19 & Calcário & & & & & & & & & & & & & \\
\hline 0 & 19.0 & $\mathrm{CO} 20$ & Calcário & & & & & & & & & & & & & \\
\hline 울 & 20.0 & CO21 & Calcário & & & & & & & & & & & & & \\
\hline 突. & 21.0 & CO22 & Calcário & 15.1 & & 16.9 & & & & & & -31.9 & -6.2 & 25.7 & -6.8 & \\
\hline$\stackrel{\widetilde{\pi}}{\varepsilon}$ & 22.0 & $\mathrm{CO} 23$ & Calcário & & & & & & & & & & & & & \\
\hline ㅎํㅇ & 23.0 & $\mathrm{CO} 24$ & Calcário & & & & & & & & & & & & & \\
\hline u & 24.0 & $\mathrm{CO} 25$ & Calcário & & & & & & & & & & & & & \\
\hline & 25.0 & CO26a & Calcário & 12.8 & & & & & & & & -31.9 & -1.0 & 30.9 & -7.0 & \\
\hline & 25.0 & CO26b & Calcário & & & & & & & & & & -0.8 & & -7.2 & \\
\hline & 26.0 & $\mathrm{CO} 27$ & Calcário & & & & & & & & & & & & & \\
\hline & 27.0 & $\mathrm{CO} 28$ & Calcário & & & & & & & & & & & & & \\
\hline & 28.0 & $\mathrm{CO} 29$ & Calcário & 20.5 & 49.4 & 33.5 & & & & & 28.9 & -31.1 & -1.6 & 29.5 & -7.1 & \\
\hline & 29.0 & CO30 & Calcário & 18.0 & & 24.3 & & & & & & -33.5 & -2.0 & 31.5 & -7.1 & \\
\hline & 30.0 & CO31 & Calcário & & & & & & & & & & & & & \\
\hline & 31.0 & CO32 & Calcário & & & & & & & & & & & & & \\
\hline & 32.0 & $\mathrm{CO} 33$ & Calcário & & & & & & & & & & & & & \\
\hline & 33.0 & CO34 & Calcário & 13.7 & 51.8 & 35.3 & & & & & 38.1 & & -1.6 & & -7.7 & \\
\hline & 34.0 & CO35 & Calcário & & & & & & & & & & & & & \\
\hline & 35.0 & CO36 & Calcário & & & & & & & & & & & & & \\
\hline & 36.0 & CO37 & Calcário & 13.9 & & & & & & & & & -0.6 & & -7.6 & \\
\hline & 37.0 & CO38 & Calcário & & & & & & & & & & -0.8 & & -7.4 & \\
\hline & 38.0 & CO39 & Calcário & & & & & & & & & & & & & \\
\hline & 39.0 & $\mathrm{CO} 40$ & Calcário & & & & & & & & & & & & & \\
\hline & 40.0 & CO41 & Calcário & & & & & & & & & & & & & \\
\hline & 41.0 & CO42 & Calcário & 16.7 & 49.8 & 25.2 & 18.1 & 31.3 & & & 33.1 & & -1.6 & & -7.6 & \\
\hline & 42.0 & $\mathrm{CO} 43$ & Calcário & 22.5 & 53.0 & 32.4 & 26.3 & & & & 30.5 & -34.9 & -2.8 & 32.1 & -7.3 & \\
\hline & 43.0 & $\mathrm{CO} 44$ & Calcário & 22.4 & 61.6 & 49.3 & 39.4 & & & & 39.2 & & -1.6 & & -7.5 & 0.7074 \\
\hline & 44.0 & CO45 & Calcário & 13.7 & 52.9 & 20.2 & 19.0 & 24.0 & & 24.1 & 39.2 & -31.6 & -2.3 & 29.3 & -7.4 & \\
\hline & 45.0 & $\mathrm{CO} 46$ & Calcário & 12.2 & & 27.9 & 20.2 & & & & & & -2.0 & & -7.8 & \\
\hline & 46.0 & CO47a & Calcário & 15.3 & & & & & & & & & -1.2 & & -8.1 & \\
\hline & 46.0 & CO47b & Calcário & & & & & & & & & & -1.4 & & -7.3 & \\
\hline & 46.0 & CO47c & Calcário & & & & & & & & & & -1.2 & & -8.3 & \\
\hline & 46.0 & co47d & Calcário & & & & & & & & & & -1.4 & & -8.1 & \\
\hline & 47.0 & $\mathrm{CO} 48$ & Calcário & 23.3 & 50.6 & 32.6 & & & & & 27.3 & & -1.8 & & -7.8 & \\
\hline & 48.0 & CO49 & Calcário & 15.8 & 47.3 & & & & & & 31.4 & -30.5 & -0.9 & 29.6 & -7.4 & 0.7076 \\
\hline & 49.0 & co50a & Calcário & 30.1 & 48.7 & 29.0 & 29.4 & 24.7 & 30.5 & 30.5 & 18.6 & -31.7 & -4.2 & 27.5 & -7.6 & \\
\hline & 49.0 & CO50b & Calcário & & & & & & & & & & -4.5 & & -7.5 & \\
\hline
\end{tabular}




\begin{tabular}{|c|c|c|c|c|c|c|c|c|c|c|c|c|c|c|c|c|}
\hline & metros & amostra & rocha & $\begin{array}{c}\delta^{34} S \\
\text { (CRS) }\end{array}$ & CAS & Lix 1 & $\begin{array}{r}\delta^{3} \\
\text { Lix } 2 \\
\end{array}$ & $\begin{array}{l}{ }^{4} S \\
\text { Lix } 3\end{array}$ & Lix 4 & Lix 5 & $\Delta^{34} S$ & $\begin{array}{l}\delta^{13} \mathrm{C} \\
\text { (Org) }\end{array}$ & $\begin{array}{c}\delta^{13} \mathrm{C} \\
\text { (Carb) }\end{array}$ & $\Delta^{13} \mathrm{C}$ & $\delta^{18} O$ & $\left.{ }^{87} \mathrm{Sr}\right|^{86} \mathrm{Sr}$ \\
\hline & 51.0 & CO51 & Calcário & 35.3 & 51.4 & 36.1 & 30.8 & 29.6 & 30.1 & & 16.1 & & -1.9 & & -7.5 & \\
\hline & 55.0 & $\mathrm{CO} 53$ & Calcário & 23.2 & 52.4 & & & & & & 29.2 & & -1.1 & & -7.1 & 0.7074 \\
\hline & 57.0 & CO54 & Calcário & 19.6 & & 27.5 & & & & & & & -1.5 & & -6.9 & \\
\hline & 59.0 & CO55 & Calcário & 14.9 & 48.9 & 18.7 & 17.4 & & & & 34.0 & -31.8 & -2.2 & 29.5 & -8.2 & \\
\hline & 61.0 & CO56 & Calcário & 11.7 & & & & & & & & & -1.6 & & -7.3 & \\
\hline & 63.0 & CO57 & Calcário & & & & & & & & & & -1.2 & & -7.9 & \\
\hline & 65.0 & c058a & Calcário & 16.4 & & & & & & & & & -1.0 & & -8.5 & \\
\hline & 65.0 & c058b & Calcário & & & & & & & & & & & & -8.6 & \\
\hline & 67.0 & CO59 & Calcário & 15.4 & 54.2 & & & & & & 38.8 & -31.9 & -2.4 & 29.4 & -8.2 & \\
\hline & 69.0 & $\mathrm{CO} 60$ & Calcário & 20.1 & 54.6 & 45.2 & & & & & 34.5 & & -2.5 & & -7.9 & 0.7074 \\
\hline \multirow{19}{*}{ 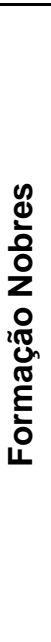 } & 0.0 & MT01 & Dolomito & 17.3 & 48.1 & 19.3 & & & & & 30.8 & & -0.9 & & -4.3 & \\
\hline & 6.5 & MT02 & Dolomito & & & & & & & & & -15.8 & -1.0 & 14.8 & -5.2 & \\
\hline & 11.0 & МТ0ЗА & Dolomito & 23.0 & 22.3 & 24.0 & 19.0 & & & & -0.7 & & -0.8 & & -4.2 & \\
\hline & 23.0 & Мт03С & Dolomito & 32.0 & 60.5 & & & & & & 28.5 & -33.3 & -0.7 & 32.5 & -4.3 & \\
\hline & 32.0 & MT04 & Dolomito & 19.3 & 22.8 & 26.0 & & & & & 3.5 & & -1.4 & & -4.3 & \\
\hline & 34.5 & MT05 & Dolomito & 17.0 & 45.8 & 26.6 & 25.9 & 23.5 & 17.5 & 13.8 & 28.8 & -32.9 & -2.1 & 30.8 & -4.1 & \\
\hline & 35.0 & MT06 & Dolomito & 23.4 & 25.9 & 24.0 & 26.3 & 26.0 & 28.8 & 28.2 & 2.5 & & -1.6 & & -4.2 & \\
\hline & 37.0 & MT06B & Dolomito & 36.1 & 60.6 & & & & & & 24.5 & & -0.2 & & -5.3 & \\
\hline & 42.5 & MT07b & Dolomito & 28.2 & 31.5 & 29.2 & & & & & 3.3 & -26.2 & -0.9 & 25.3 & -3.8 & \\
\hline & 42.5 & MT07a & Dolomito & & & & & & & & & & -1.0 & & -3.1 & \\
\hline & 43.0 & MT08 & Dolomito & & 52.4 & 33.5 & & & & & & -25.6 & -1.5 & 24.1 & -3.6 & \\
\hline & 45.5 & MT09 & Dolomito & 29.2 & & & & & & & & -26.0 & -2.3 & 23.7 & -3.0 & \\
\hline & 52.0 & MT10 & Dolomito & 28.3 & 56.2 & 27.2 & & & & & 27.9 & & -0.2 & & -4.6 & \\
\hline & 57.0 & MT11 & Dolomito & 29.8 & 60.1 & & & & & & 30.2 & & 0.2 & & -4.4 & \\
\hline & 59.0 & MT12 & Dolomito & 41.1 & 61.2 & & & & & & 20.1 & & 0.3 & & -4.5 & \\
\hline & 65.0 & MT12Ca & Dolomito & 29.2 & & & & & & & & & -0.3 & & -4.6 & \\
\hline & 65.0 & $\mathrm{MT} 12 \mathrm{Cb}$ & Dolomito & & & & & & & & & & -0.3 & & -3.6 & \\
\hline & 93.0 & MT12E & Dolomito & & & & & & & & & & 0.1 & & -3.7 & \\
\hline & 105.0 & MT12G & Dolomito & 42.4 & & & & & & & & & -0.2 & & -4.2 & \\
\hline \multirow{24}{*}{ 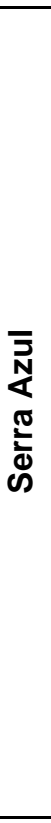 } & 80.0 & NB101 & siltito & 28.4 & & & & & & & & & & & & \\
\hline & 76.0 & NB103a & Calcário & & & & & & & & & & -3.8 & & -5.7 & \\
\hline & 76.0 & NB103b & Calcário & & & & & & & & & & -7.5 & & -7.0 & \\
\hline & 75.8 & NB104 & Calcário & 24.4 & & & & & & & & & -3.2 & & -5.5 & 0.7084 \\
\hline & 75.6 & NB105 & Calcário & 21.4 & & & & & & & & & -3.5 & & -6.1 & \\
\hline & 75.1 & NB106 & Calcário & 17.3 & & & & & & & & & -3.4 & & -5.7 & \\
\hline & 75.1 & NB106t & Calcário & 17.8 & & & & & & & & & & & & \\
\hline & 74.9 & NB107 & Calcário & & & & & & & & & & -4.8 & & -6.2 & 0.7085 \\
\hline & 74.6 & NB108 & Calcário & 22.5 & & & & & & & & & -4.7 & & -6.0 & \\
\hline & 73.4 & NB110 & Calcário & 26.9 & & & & & & & & & -5.3 & & -7.3 & \\
\hline & 73.1 & NB111d & Calcário & & & & & & & & & & -6.0 & & -6.4 & \\
\hline & 73.1 & NB111a & Calcário & & & & & & & & & & -7.3 & & -7.6 & \\
\hline & 73.1 & NB111b & Calcário & & & & & & & & & & -5.9 & & -6.5 & \\
\hline & 73.1 & NB111c & Calcário & & & & & & & & & & -5.6 & & -6.9 & \\
\hline & 73.1 & NB111e & Calcário & & & & & & & & & & -5.7 & & -7.1 & \\
\hline & 73.1 & NB111f & Calcário & & & & & & & & & & -6.3 & & -7.2 & \\
\hline & 73.1 & NB111g & Calcário & & & & & & & & & & -7.4 & & -9.1 & \\
\hline & 72.3 & NB112 & Calcário & & & & & & & & & & -6.4 & & -7.3 & \\
\hline & 72.1 & NB113 & Calcário & 14.9 & & & & & & & & & -4.2 & & -6.8 & 0.7084 \\
\hline & 72.0 & NB114 & Calcário & & & & & & & & & & -4.3 & & -7.0 & \\
\hline & 71.5 & NB115 & Calcário & & & & & & & & & & -4.7 & & -6.9 & \\
\hline & 69.5 & NB116 & Calcário & & & & & & & & & & -5.0 & & -7.5 & 0.7083 \\
\hline & 69.0 & NB117 & Calcário & & & & & & & & & & -4.6 & & -7.2 & \\
\hline & 68.8 & NB118 & Calcário & 15.4 & & & & & & & & & -4.7 & & -7.3 & \\
\hline
\end{tabular}

Nota: erros de $\delta^{13} \mathrm{C}= \pm 0,05 \%$ e $\delta^{18} \mathrm{O}= \pm 0,07 \%$; valores de deltas normalizados para os padrões V-PDB (carbono) e V-CDT (enxofre) e expressos em $\%$. 


\section{DISCUSSÃO}

Para avaliar a magnitude dos efeitos diagenéticos nas composições dos isótopos de enxofre das amostras ediacaranas das formações Guia e Nobres, foram analisados os precipitados de $\mathrm{BaSO}_{4}$ de ambos lixiviados e extratos CAS para cada uma das amostras. Os resultados mostraram que os lixiviados, que são considerados não representativos das condições deposicionais (artefatos analíticos ou pósdeposicionais), são consistentemente empobrecidos em ${ }^{34} \mathrm{~S}$ quando comparados à fração CAS para os ambientes de talude e de inframaré das formações Guia e Nobres (Figura 4), apresentando uma diferença de até 31\%. Porém, nas amostras da Formação Nobres, interpretadas como de ambientes de intermaré superior a supramaré, os valores de $\delta^{34} S$ de ambos CAS e CRS, entre 19 e 26\%, são similares aos dos respectivos lixiviados (seção 3, Figura 3). Esta homogeneização entre as três fases (CAS, CRS e sulfato diagenético) pode ocorrer durante a exposição em ambiente tipo sabkha. Durante a exposição de uma planície árida, se formam evaporito e dolomita eo-diagenética concomitantes, pela transferência do cálcio presente nos carbonatos para os sulfatos. O sulfeto e a matéria orgânica presentes podem ser parcialmente oxidados durante a exposição do sedimento, gerando ${ }^{32} \mathrm{~S}$ livre, a ser utilizado na cristalização dos sulfatos evaporíticos.

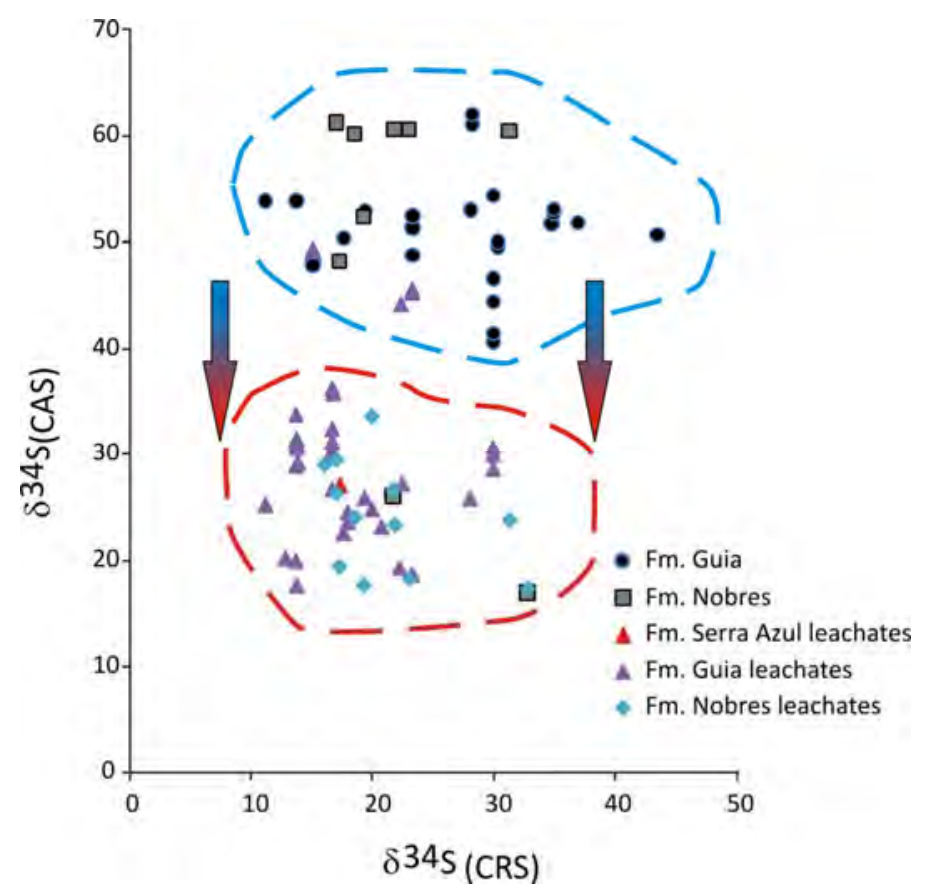

Figura 3. Diagrama com os valores $\delta^{34} \mathrm{~S}$, em per mil, de CRS (sulfeto) versus CAS (sulfato) para as amostras analisadas. Observar a existência de dois grupos: o contorno azul inclui os extratos CAS; o contorno vermelho inclui os lixiviados. 
Os valores extremamente pesados observados neste trabalho $\left(\delta^{34} S_{(\mathrm{CAS})}\right.$ de até $61 \%$ e $\delta^{34} S_{(C R S)}$ de até $43 \%$ ), podem significar um aumento de ${ }^{34} S$ no oceano ediacarano como um resultado de uma anoxia difundida e a predominância de bactérias redutoras de sulfato nos sedimentos e na coluna d'água, onde houvesse matéria orgânica e sulfato suficientes para sustentar o ecossistema microbiano. Este enriquecimento expressivo em ${ }^{34} \mathrm{~S}$, associado a um fracionamento isotópico $\Delta^{34} \mathrm{~S}$ predominantemente acima de 28\% (maior que a média dos mares atuais), sugere uma intensa bioatividade de bactérias redutoras de sulfato, com conseqüente redução do reservatório de sulfato disponível.

Assumindo um reservatório limitado, a composição isotópica do sulfato dissolvido pode mudar rapidamente com pequenas mudanças nos fluxos de entrada/saída de enxofre (Newton \& Bottrell, 2007), de forma que a remoção de um grande volume de sulfeto dissolvido na água do mar, na forma de pirita rica em ${ }^{32} \mathrm{~S}$, e sua transferência para o reservatório sedimentar permite o enriquecimento da água em ${ }^{34} \mathrm{~S}$. Da mesma forma, o enriquecimento da água em ${ }^{34} \mathrm{~S}$ pode estar relacionado à inibição de fontes ricas em enxofre leve, o que inclui um fluxo insignificante de enxofre intemperisado proveniente do continente (possivelmente associado com clima árido) e/ou uma baixa atividade vulcânica submarina. Um segundo fator pode estar associado à uma explosão na bioatividade de bactérias redutoras de sulfato, principais responsáveis pelo fracionamento do enxofre (Kaplan \& Rittenberg, 1964; Chambers \& Trudinger, 1979), cujo intenso consumo de sulfato reduziria drasticamente o reservatório de sulfato dissolvido e aumentaria o reservatório de sulfeto dissolvido, tendo como resultado um ambiente anóxico e sulfídico.

A produção de $\mathrm{HS}^{-}$pelas bactérias redutoras de sulfato é também acompanhada da produção de $\mathrm{CO}_{2}$ rico em ${ }^{12} \mathrm{C}$. Assim, uma explosão da bioatividade das bactérias redutoras de enxofre estaria acompanhada do enriquecimento de ${ }^{12} \mathrm{C}$ na água do mar. Esta associação pode ser verificada na Formação Guia (seção 2, Figura 2), onde uma tendência negativa pode ser observada nos valores de $\delta^{13} \mathrm{C}$ obtidos nos carbonatos enquanto que os valores de $\delta^{34} S$ dos sulfatos assumem uma tendência positiva. Esta tendência negativa se mantém apesar do amplo fracionamento do carbono $\left(\Delta^{13} \mathrm{C}\right.$ entre 39 e 32\%o) acima dos 155 metros, que indica a presença de organismos 
fotossintetizantes extremamente ativos, enriquecendo o meio em ${ }^{13} \mathrm{C}$, porém, não suficiente ainda para sobrepor o efeito das bactérias redutoras de sulfato.

Na Formação Nobres (seção 3, Figura 2), esta relação não é nítida. Além dos valores mais leves de $\delta^{34} \mathrm{~S}$ obtidos nos sulfatos, anteriormente discutidos como de origem diagenética, os valores mais pesados de $\delta^{34} S$ (> 50\%) estão associados a um fracionamento pouco menor ( $\Delta^{34} S$ inferior a 32\%) que o encontrado na Formação Guia. Somando-se a isso, os valores de $\delta^{13} \mathrm{C}$ obtidos nos carbonatos são menos negativos e oscilam em torno de 0\% no topo dessa seção. Esta configuração se assemelha mais à inibição das fontes de ${ }^{32} \mathrm{~S}$, causando uma restrição do reservatório de sulfato dissolvido, com a diminuição da bioprodução bacteriana de $\mathrm{HS}^{-}$e $\mathrm{CO}_{2}$, de maneira que os organismos fotossintetizantes consigam enriquecer a água em ${ }^{13} \mathrm{C}$. Exceção é feita para as amostras em 630 m, típicas de ambiente de intermaré a supramaré, com evidências de exposição subaérea. Estas três amostras apresentam valores de $\delta^{13} \mathrm{C}_{(\mathrm{carb})}$ mais negativos (- 2\%o) e valores de $\delta^{13} \mathrm{C}_{(\mathrm{org})}$ menos negativos (- 26\%o), mostrando um menor fracionamento por organismos fotossintetizantes $\left(\Delta^{13} \mathrm{C}\right.$ de $24 \%$ o). As respectivas amostras não forneceram CAS ou CRS, impossibilitando a avaliação do fracionamento do enxofre. Este comportamento isotópico pode estar relacionado à resposta destes organismos à exposição da planície de maré, onde os organismos marinhos fotossintetizantes seriam submetidos a um intenso estresse, com redução de sua bioatividade.

As amostras calcárias da Formação Serra Azul, no topo da sucessão estudada, não forneceram precipitados de CAS, porém estas amostras preservaram valores $\delta^{34} \mathrm{~S}_{(\mathrm{CRS})}$ variando de 13 a $28 \%$, associado à anomalia $\delta^{13} \mathrm{C}_{(\mathrm{carb})}$ negativa pós-glacial (6\%; Figura 2). Seus valores $\delta^{34} \mathrm{~S}_{(\mathrm{CRS})}$ mais leves sugerem um aumento do reservatório de sulfato dissolvido na água do mar, por sua vez associado à oxigenação de ambientes superficiais ou à atividade vulcânica submarina. Se for assumido que o sulfato da água do mar tenha permanecido semelhantemente enriquecido em ${ }^{34} \mathrm{~S}$ neste período, o decréscimo nos valores de $\delta^{34} S_{(\mathrm{CRS})}$ refletiria um fracionamento de maior magnitude, próximo ao limite de fracionamento isotópico por bactérias redutoras de enxofre (46\%; Canfield \& Teske, 1996), reforçando uma abundante disponibilidade de sulfato na água do mar. 


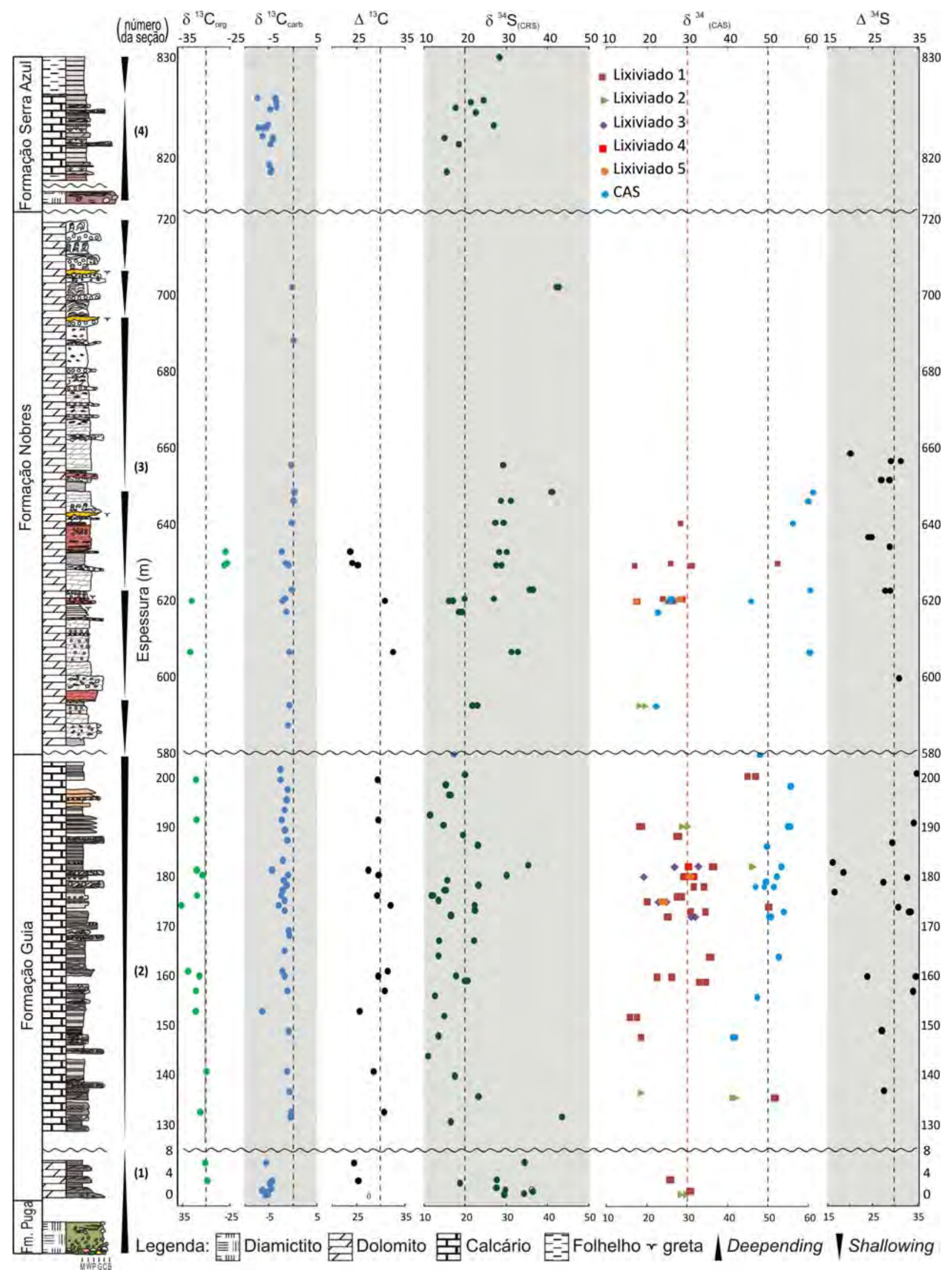

Figura 4: Curvas quimioestratigráficas de carbono e enxofre, nas fases reduzida e oxidada, para as seções estudadas das formações Guia, Nobres e Serra Azul. A Formação Serra Azul não forneceu extratos de CAS e carbono orgânico. 
As composições isotópicas de ambos os precipitados CAS e CRS da sucessão estudada são ainda mais enriquecidas em ${ }^{34} \mathrm{~S}$ que o encontrado para outras sucessões pós-Marinoanas na Namíbia (Hurtgen et al., 2006), Oman (Fike et al., 2006), Estados Unidos (Kaufman et al., 2007) e China (McFadden et al., 2008), cujos valores de $\delta^{34} S_{\text {(CAS) }}$ estão abaixo de $45 \%$ e de $\delta^{34} S_{\text {(CRS) }}$ são inferiores a $30 \%$. Nos trabalhos de Hurtgen et al. (2006), na Namíbia, e Li et al. (2010), na China, foram identificadas variações isotópicas com a profundidade ao longo da plataforma, sugerindo a presença de um ambiente redox estratificado.

A proposta de Hurtgen et al. (2006), para a plataforma Otavi, assume uma estratificação do oceano em duas camadas, uma euxínica profunda e outra mais rasa oxigenada. Os autores sugerem que o degelo da snowball tenha propiciado a oxigenação da camada superior do oceano, até então completamente euxínico, dominada pela água de degelo. Esta camada superior dominaria a região plataformal no início da trangressão pós-glacial, contendo sulfato resultante da oxidação do sulfeto dissolvido proveniente da camada euxínica (relicto da snowball Earth). Numa primeira fase, que corresponde à deposição das capas carbonáticas, teria se estabelecido uma forte quimioclina entre estas duas camadas. Com o avanço da transgressão marinha, esta transição brusca entre as duas camadas daria lugar a uma zona de mistura, que recobriria parte da plataforma. Os autores obtiveram o registro dos depósitos de mar profundo (euxínico) e sugerem que, ao início da regressão subseqüente, o mar possa ter sido completamente oxigenado, ou que o soerguimento isostático possa ter reposicionado a plataforma profunda acima da zona de mistura. O resultado seriam duas seções plataformais com as porções de base e de topo isotopicamente homogêneas $\left(\delta^{34} S_{(C A S)} \sim 30 \%\right.$ e $\sim 40 \%$, respectivamente) e intermediária distintas entre plataforma rasa $\left(\delta^{34} S_{(C A S)} \sim 43 \%\right)$ e profunda $\left(\delta^{34} S_{(C A S)} \sim 18 \%\right)$.

O modelo de Li et al. (2010), para a bacia Nanhua, China, postula a existência de um oceano estratificado em uma camada superficial oxigenada e o restante anóxico. Na camada anóxica, existiria uma cunha sulfídica metaestável em profundidades intermediárias, dentro de uma coluna d'água ferruginosa. A camada oxigenada conteria sulfato proveniente do continente, que seria consumido por bactérias redutoras de sulfato responsáveis por manter a cunha sulfídica através da liberação constante de HS: No registro geológico, a camada oxigenada que recobriria a plataforma rasa não 
foi observada, sendo que o resultado para os depósitos da plataforma interna dentro da cunha euxínica seria a precipitação de piritas empobrecidas em ${ }^{34} S\left(\delta^{34} S_{\text {(CRS) }}\right.$ de $-20 \mathrm{a}$ $10 \%$ ) com alto fracionamento isotópico de enxofre ( $\Delta^{34} S$ de 15 a $46 \%$ ), enquanto que nas águas profundas ferruginosas da plataforma profunda seriam depositadas piritas ricas em ${ }^{34} S\left(\delta^{34} S_{(C R S)}\right.$ de 10 a 35\%) com menor fracionamento isotópico de $\left(\Delta^{34} S\right.$ de 0 a $15 \%$ ).

A Faixa Paraguai ainda não dispõe de análises isotópicas de enxofre em diferentes seções ao longo da bacia, que permitam uma comparação do comportamento isotópico entre ambiente raso e profundo. Porém, algumas considerações podem ser feitas diante dos modelos propostos para as sucessões Otavi e Nanhua. Hurtgen et al. (2006) sugerem que os valores mais pesados de $\delta^{34} S_{\text {(CAS) }}$ estejam associados aos ambientes mais rasos, que está implícito no modelo de Li et al. (2010), e também é observado na seção estudada. No entanto, a magnitude dos valores $\delta^{34} \mathrm{~S}_{\text {(CAS) }}$ encontrados na Faixa Paraguai é superior aos da plataforma Otavi. $\mathrm{Li}$ et al. (2010) propõem um menor fracionamento isotópico de enxofre para as sucessões mais profundas, também implícito no modelo de Hurtgen et al. (2006) e observado em apenas uma de suas seções. Este fracionamento reduzido em sucessões profundas não foi observado na seção de talude estudada (seção 2, Figura 2), salvo raras exceções, com a deposição de piritas mais leves no talude (predominam valores de $\delta^{34} S_{\text {(CRS) }}$ abaixo de $25 \%$ ) e mais pesadas na plataforma rasa (predominam valores de $\delta^{34} \mathrm{~S}_{(\mathrm{CRS})}$ acima de $25 \%$ ). Porém, na seção de margem de bacia (seção 1, Figura 2) as piritas possuem valores de $\delta^{34} \mathrm{~S}_{\text {(CRS) }}$ predominantemente mais pesados (28 a 38\%), não havendo dados isotópicos de CAS para avaliar o grau de fracionamento. Na seção de plataforma profunda (seção 4, Figura 2), foram observados valores de $\delta^{34} S_{(\text {CRS) }}$ mais leves na base $(15 \%)$ tendendo a valores mais pesados para o topo $(28 \%)$.

Diante da comparação dos dados deste trabalho com os modelos propostos, percebe-se que não há uma adequação perfeita, podendo-se fazer algumas considerações. No modelo de Hurtgen et al. (2006), a seção de talude e plataforma profunda (seção 2, Figura 2) teria se depositado dentro da zona de mistura, apresentando valores de $\delta^{34} S_{\text {(CAS) }}$ mais leves. De fato os valores encontrados nesta seção são predominantemente mais leves que aqueles da seção mais rasa (seção 3, Figura 2), mas não apresenta valores tão leves quanto o esperado para o mecanismo 
de oxidação do sulfeto proveniente de águas profundas, como proposto por Hurtgen et al. (2006). Para os ambientes mais rasos e restritos, Hurtgen et al. (2006) sugerem que o sulfato seja limitado e proveniente do continente, levando a um fracionamento bacteriano em sistema fechado (ambiente restrito) e enriquecimento da água em ${ }^{34} \mathrm{~S}$. Esta configuração pode estar representada na seção 3 estudada (Figura 2).

O modelo de Li et al. (2010) responde parcialmente aos resultados encontrados para área de estudo. As seções mais rasa (seção 3) e mais profunda (seção 1) apresentam piritas relativamente enriquecidas em ${ }^{34} \mathrm{~S}$, enquanto que a seção de

plataforma profunda (seção 4) contem piritas mais leves (empobrecidas em ${ }^{34} \mathrm{~S}$ ), como esperado no modelo. Porém, os depósitos de talude apresentaram as piritas mais leves, sugerindo um reposicionamento da cunha euxínica entre a plataforma profunda e o talude inferior. Não obstante, o fracionamento reduzido, associado à ocorrência de piritas pesadas depositadas fora da cunha euxínica, não é observado na seção 3. Isto indica que a bioatividade das bactérias redutoras de sulfato não se restringem à cunha euxínica, originalmente concebida como o resultado da liberação bacteriana constante de HS.

A escassez de dados isotópicos de enxofre na Faixa Paraguai dificulta não só a correlação com um destes modelos, como também a proposição de outros modelos. Mas existe a possibilidade de que as variações isotópicas observadas neste estudo, para o mar ediacarano, estejam relacionadas mais à evolução dos microorganismos ao longo do tempo que à sua distribuição ao longo da bacia.

\section{CONCLUSÕES}

A assinatura isotópica registrada nas rochas carbonáticas da Faixa Paraguai, como demonstrado por ambas as fases reduzida e oxidada de carbono e de enxofre, sugerem que o mar ediacarano onde elas se depositaram era predominantemente anóxico e euxínico. Além disso, os valores de $\delta^{34} S$ anomalamente pesados, tanto na pirita quanto no sulfato, podem estar relacionados à diminuição do reservatório de sulfato dissolvido na água do mar, relacionado à redução do intemperismo continental e/ou da atividade vulcânica submarina. No entanto, o reservatório de sulfato se mantinha suficiente para garantir um amplo fracionamento bacteriano $\left(\Delta^{34} S\right.$ de até 
35\%). Na seção mais profunda, equivalente da capa carbonática marinoana, observouse uma redução considerável do fracionamento isotópico de carbono $\left(\Delta^{13} C \sim 25 \%\right)$, possivelmente pela inibição dos organismos fotossintetizantes. É possível que tenha ocorrido o mesmo com as bactérias redutoras, de acordo com a presença de pirita isotopicamente pesada $\left(\delta^{34} \mathrm{~S}_{(\mathrm{CRS})} \sim 32 \%\right)$ em rochas depositadas imediatamente após os diamictitos glaciais. O restante da seção mostra um aumento no fracionamento do carbono $\left(\Delta^{13} \mathrm{C} \sim 30 \%\right)$, interpretado como resultado do restabelecimento dos organismos fotossintetizantes, anterior à difusão das bactérias redutoras, como observado na base da seção $2\left(\delta^{13} \mathrm{C}\right.$ próximo de $0 \%, \Delta^{13} \mathrm{C}$ de $31 \%$ e $\delta^{34} \mathrm{~S}_{(\mathrm{CRS})}$ de $45 \%$ ). O restabelecimento das bactérias redutoras de sulfato parece ter sido mais lento, que posteriormente se sobrepõem à bioprodutividade dos organismos fotossintetizantes para o topo da sucessão, como observado no restante da seção $2\left(\delta^{13} \mathrm{C}\right.$ de $-2,5 \%$, $\Delta^{13} \mathrm{C}$ de $33 \%$, $\delta^{34} \mathrm{~S}_{(\mathrm{CRS})} \sim 18 \%$ e $\Delta^{34} \mathrm{~S}$ de $\sim 33 \%$ ). Em ambientes mais rasos, os organismos fotossintetizantes parecem desenvolver um melhor desempenho que as bactérias redutoras $\left(\delta^{13} \mathrm{C}\right.$ próximo de $0 \%, \Delta^{13} \mathrm{C}$ de $33 \%, \delta^{34} \mathrm{~S}_{(\mathrm{CRS})}$ maior que $25 \%$ e $\Delta^{34} \mathrm{~S}$ de $\sim 28 \%$ ), exceto durante a exposição da planície de maré, onde a bioprodutividade fotossintética diminue drasticamente $\left(\delta^{13} \mathrm{C}\right.$ de $-2,5 \%, \Delta \Delta^{13} \mathrm{C}$ de $23 \%$ ). Estas observações não atendem à integralidade de nenhum dos modelos propostos na literatura, que sugerem uma estratificação dos oceanos ediacaranos. Assim, existe a possibilidade de que as variações isotópicas encontradas na Faixa Paraguai sejam referentes mais à evolução biológica ao longo do Ediacarano que à estratificação dos oceanos. No entanto, estas considerações carecem de mais estudos isotópicos de enxofre em outras seções correlatas da área estudada, especialmente em ambientes mais proximais e mais distais.

\section{REFERÊNCIAS}

Alvarenga, C.J.S., Trompette, R. 1992. Glacial influenced turbidite sedimentation in the uppermost Proterozoic and Lower Cambrian of the Paraguay Belt (Mato Grosso, Brazil). Palaeogeography, Palaeoclimatology, Palaeoecology, 92: 85-105. 
Alvarenga, C.J.S., Santos, R.V., Dantas, E.L. 2004. C-O-Sr isotopic stratigraphy of cap carbonates overlying Marinoan-age glacial diamictites in the Paraguay Belt, Brazil. Precambrian Research, 131: 1-21.

Alvarenga, C.J.S., Figueiredo, M.F., Babinski, M., Pinho, F.E.C. 2007. Glacial diamictites of Serra Azul Formation (Ediacaran, Paraguay Belt): Evidence of the Gaskiers glacial event in Brazil. Journal of South American Earth Science, 23: 236241.

Canfield, D.E. 1991. Sulfate reduction in deep-sea sediments. American Journal of Science, 291: 177-188

Canfield, D.E., Teske, A., 1996. Late Proterozoic rise in atmospheric oxygen concentration inferred from phylogenetic and sulphurisotopic sudies. Nature 382 , 127-132.

Chambers, L.A., Trudinger, P.A. 1979. Microbiological fractionation of stable sulfur isotopes: a review and critique. Geomicrobiology Journal, 1: 249-293.

Figueiredo, M.F., Babinski, M., Alvarenga, C.J.S., Pinho, F.E.C. 2008. Nova unidade litoestratigráfica registra glaciação Edicarana em Mato Grosso: Formação Serra Azul. Geologia-USP, 8: 65-75.

Fike D. A., Grotzinger J. P., Pratt L. M., Summons R. E. 2006. Oxidation of the Ediacaran Ocean. Nature, 444: 744-747.

Hurtgen, M.T., Halverson, G.P., Arthur, M.A., Hoffman, P.F. 2006. Sulfur cycling in the aftermath of a 635-Ma snowball glaciation: Evidence for a syn-glacial sulfidic deep ocean. Earth and Planetary Science Letters, 245: 551-570.

Jorgensen, B.B. 1982. Mineralization of organic matter in the sea bed - the role of sulphate reduction. Nature, 296: 643-645.

Kaplan, I.R., Rittenberg, S.C. 1964. Microbiological fractionation of sulphur isotopes. Journal of General Microbiology, 34, 195-212.

Kaufman, A.J., Corsetti, F.A., Varni, M.A. 2007. The effect of rising atmospheric oxygen on carbon and sulfur isotope anomalies in the Neoproterozoic Johnnie Formation, Death Valley, USA. Chemical Geology, 237: 47-63.

McFadden, K.A., Huang, J., Chu, X., Jiang, G., Kaufman, A.J., Zhou, C., Yuan, X., Xiao, S. 2008. Pulsed oxidation and biological evolution in the Ediacaran Doushantuo Formation. PNAS, 105: 3197-3202.

Li, C., Love, G.D., Lyons, T.W., Fike, D.A., Sessions, A.L., Chu, X. 2010. A stratified redox model for the Ediacaran ocean. Science, 328: 80-83. 
Lin, S., Morse, J.W. 1991. Sulfate reduction and iron sulfide mineral formation in Gulf of Mexico anoxic sediments. American Journal of Science, 291: 55-89.

Marenco, P.J., Corsetti, F.A., Hammond, D.E., Kaufman, A.J., Bottjer, D.J., 2008. Oxidation of pyrite during extraction of carbonate associated sulfate. Chemical Geology, 247: 124-132.

Newton, R., Bottrell, S. 2007. Stable isotopes of carbon and sulphur as indicators of environmental change: past and present. Journal of the Geological Society, London, 164: 691-708.

Nogueira, A.C.R., Riccomini, C., Sial, A.N., Moura, C.A.V., Fairchild, T.R. 2003. Softsediment deformation at the base of the Neoproterozoic Puga cap carbonate (southwestern Amazon craton, Brazil): Confirmation of rapid icehouse to greenhouse transition in snowball Earth. Geology, 31: 613-616.

Nogueira, A.C.R., Riccomini, C. 2006. Grupo Araras (Neoproterozóico) na parte norte da Faixa Paraguai e Sul do Craton Amazônico, Brasil. Revista Brasileira de Geociências, 36: 576-587.

Sinninghe Damste, J.S., de Leeuw, J.W. 1990. Analysis, structure and geochemical significance of organically-bound sulphur in the geosphere: state of the art and future research. Organic Geochemistry, 16: 1077-1101. 


\title{
CAPÍTULO 5
}

\section{GEOCRONOLOGIA, PROVENIÊNCIA E TECTÔNICA}

Neste capítulo são apresentados estudos geocronológicos utilizando-se os métodos radiométricos $\mathrm{Pb}-\mathrm{Pb}$ em carbonatos, $\mathrm{K}-\mathrm{Ar}$ em clastos vulcânicos e $\mathrm{Sm}-\mathrm{Nd}$ (idade modelo $\mathrm{T}_{\mathrm{DM}}$ ) em rochas terrígenas, com a finalidade de se estabelecer a idade máxima de deposição da Formação Serra Azul e a proveniência das rochas sedimentares da Faixa Paraguai. Estes dados foram organizados em dois artigos, a serem submetidos a revistas indexadas.

\subsection{ARTIGO 4: IDADES Pb-Pb DE CARBONATOS DA FAIXA PARAGUAI NORTE}

\author{
Milene F. Figueiredo e Marly Babinski
}

Instituto de Geociências, Universidade de São Paulo (USP), São Paulo, SP - Brasil. E-mail: milene.figueiredo@gmail.com, babinski@usp.br

\section{RESUMO}

A bacia precursora da Faixa Paraguai Norte registrou a ocorrência de duas glaciações (formações Puga e Serra Azul), que vêm sendo correlacionadas às glaciações Marinoana e Gaskiers, por quimioestratigrafia isotópica. Esta correlação é relativa e requer idades radiométricas para uma correlação temporal mais precisa. Neste trabalho, foram datados os calcários pertencentes às formações Guia e Serra Azul pela metodologia isotópica $\mathrm{Pb}-\mathrm{Pb}$. Duas idades obtidas apresentaram erro bastante alto para a Formação Guia (580 $\pm 77 \mathrm{Ma})$ e para uma das lentes calcárias da Formação Serra Azul (639 $\pm 89 \mathrm{Ma})$, dificultando a interpretação do seu real significado. Uma terceira idade, de $596 \pm 26 \mathrm{Ma}$, foi obtida em camadas calcárias mais jovens da Formação Serra Azul e é interpretada como idade de sedimentação destas 
rochas. Estes dados reforçam que os diamictitos da Formação Serra Azul foram depositados durante a glaciação Gaskiers, como previamente proposto com base em estratigrafia.

\section{INTRODUÇÃO}

A Era Neoproterozoica é marcada por significativos eventos climáticos, tectônicos, ambientais e biológicos, especialmente durante o Ediacarano. A correlação temporal destes eventos registrados nas sucessões sedimentares, espalhadas ao redor do mundo, bem como sua ordenação, depende de mais dados geocronológicos, ainda insuficientes a este propósito.

A hipótese de uma glaciação global, conhecida como Glaciação Marinoana (Kirschvink, 1992; Hoffman et al., 1998), exigia uma contemporaneidade dos diamictitos encontrados em vários continentes, o que incentivou as datações radiométricas como maneira de comprovar sua extensão global. A idade do término deste evento glacial foi estabelecida pela datação de tufos vulcânicos intercalados nos diamictitos ou nos carbonatos de capa. Estas consistem de idades U-Pb em zircões de 635,5 $\pm 1,2 \mathrm{Ma}$ para a Formação Ghaub, Namíbia (Hoffmann et al., 2004) e de 635,23 \pm 0,48 Ma para os carbonatos de capa da Formação Doushantuo, China (Condon et al., 2005). Porém, as demais sucessões encontradas no Brasil (Formação Puga; Nogueira et al., 2003), em Oman (Membro Fiq da Formação Ghadir Manqil; Brasier et al., 2000), na Austrália (Formação Elatina; Preiss, 2000) na Sibéria (Formação Marnya; Sovetov, 2008), Canadá (Formação Stelfox; Hoffman \& Schrag, 2002) e Svalbard (Formação Polarishbreen; Halverson et al., 2004) não possuem idades radiométricas e têm sido correlacionadas a esta glaciação global com base na quimioestratigrafia isotópica de $\mathrm{C}$ e Sr.

Uma glaciação posterior a esta, de menor proporção, foi registrada em diamictitos glaciais ediacaranos em Newfoundland (Formação Gaskiers; Eyles \& Eyles, 1989). A presença de dois níveis de tufos vulcânicos nos diamictitos permitiu a obtenção das idades U-Pb em zircões de 583,7 \pm 0,5 Ma a 582,1 \pm 0,4 Ma (Bowring et al., 2003). Recentemente, diamictitos glaciais de possível correlação com a Glaciação Gaskiers tem sido encontrados no Brasil (Formação Serra Azul; Figueiredo et al., 2008) e Noruega (formações Moelv e Mortensnes; Bingen et al., 2005; Halverson et al., 2005). No entanto, não existem idades radiométricas que confirmem esta correlação. 
Além disso, perturbações no ciclo do carbono foram observadas ao longo do Ediacarano, havendo, pelo menos, três eventos de enriquecimento de ${ }^{12} \mathrm{C}$ na água do oceano. As interpretações para estas anomalias são diversas, mas a primeira está associada aos carbonatos de capa depositados imediatamente após a Glaciação Marinoana e uma das outras duas podem estar relacionadas à Glaciação Gaskiers (Myrow \& Kaufman, 1999). A anomalia mais jovem é marcante e de aparente longa duração, conhecida como evento Shuram, não apresentando diamictitos associados. Uma anomalia intermediária foi reconhecida na China (Formação Doushantuo; McFadden et al., 2008) e correlacionada à Glaciação Gaskiers (Condon et al., 2005), embora não exista diamictitos associados. Esta correlação é questionada pela idade $\mathrm{Pb}-\mathrm{Pb}$ de $599 \pm 4 \mathrm{Ma}$ obtida anteriormente em apatita presente em fosfato de níveis estratigráficos superiores à segunda anomalia, em seção distinta da mesma bacia (Barfod et al., 2002).

A inexistência de tufos vulcânicos ao longo da sucessão sedimentar da Faixa Paraguai Norte e a ocorrência de carbonatos levaram à escolha da aplicação do método $\mathrm{Pb}-\mathrm{Pb}$ para se obter informações sobre a possível idade das anomalias isotópicas observadas e da Formação Serra Azul, possível correlata da Glaciação Gaskiers (Alvarenga et al., 2007; Figueiredo et al., 2008). A aplicação da metodologia isotópica $\mathrm{Pb}-\mathrm{Pb}$ em carbonatos é relativamente recente (Moorbath et al., 1987) e tem sido pouco utilizada nos carbonatos pré-cambrianos, pois o sistema isotópico pode ser afetado por eventos tectônicos posteriores, dificultando sua datação. Mesmo assim, idades isocrônicas de boa qualidade têm sido obtidas em carbonatos neoproterozóicos no Cráton do São Francisco (Babinski et al., 1995, 1999, 2007), no Cráton Amazônico (Babinski et al., 2006), na Namíbia (Fölling et al., 2000) e na Rússia (Kaurova et al., 2010).

\section{PROCEDIMENTOS ANALÍTICOS}

As análises isotópicas $\mathrm{Pb}-\mathrm{Pb}$ em carbonatos foram realizadas no Centro de Pesquisas Geocronológicas da Universidade de São Paulo e seguiram os procedimentos descritos por Babinski et al. (1999). As amostras de carbonatos foram trituradas e os fragmentos (ca. 0,1-0,2 cm) lavados com $\mathrm{H}_{2} \mathrm{O}$ tri-destilada e secados. Cerca de $500 \mathrm{mg}$ de amostra foi dissolvida através de dois lixiviados utilizando $\mathrm{HBr}$ 0,7 N. Somente o segundo lixiviado (L2) foi utilizado para análise. A solução obtida foi 
submetida à purificação de $\mathrm{Pb}$ através da técnica de troca iônica, sendo posteriormente depositada em filamento de rênio para a determinação das composições isotópicas de $\mathrm{Pb}$, utilizando o espectrômetro de massa Finnigan MAT 262. O fracionamento isotópico foi corrigido através de análises de padrões de Pb NBS 981. O branco analítico de Pb variou entre 30 e $90 \mathrm{pg}$. As idades foram determinadas através do software Isoplot (Ludwig, 2009).

\section{GEOLOGIA LOCAL}

As amostras de calcário analisadas foram coletadas na região dos municípios de Nobres e Bauxi (Figura 1). Nesta região serrana, encontram-se as rochas dobradas, mas não metamorfisadas, da Faixa Paraguai, que registram duas glaciações associadas a duas respectivas anomalias negativas de carbono. Estas glaciações são representadas pelas formações Puga (Maciel, 1959) e Serra Azul (Alvarenga et al., 2007; Figueiredo et al., 2008), enquanto que as anomalias isotópicas de carbono foram registradas nos carbonatos do Grupo Araras e numa lente calcária da Formação Serra Azul.

\section{Formação Puga}

A Formação Puga (figuras 1 e 2) pode ser encontrada ao longo de toda a Faixa Paraguai Norte, com uma litologia marcada pela presença de paraconglomerados petromíticos com matriz de natureza grauvaqueana argilo-arenosa a mais grossa, com clastos distribuídos caoticamente pela matriz. Os clastos são de vários tamanhos, podendo atingir até matacões, de composição (quartzo, sílex, feldspatos, calcários, granitos e rochas básicas) e arredondamento variados (Ribeiro Filho et al., 1975; Barros et al., 1982). Esta formação atualmente é correlacionada à Glaciação Marinoana de $635 \mathrm{Ma}$ (Hoffman et al, 2004), com base em razões isotópicas de C e O (Nogueira et al., 2003; Alvarenga et al., 2004; Trindade et al., 2003) e idade radiométrica Pb-Pb de 627 Ma obtida nos carbonatos do Grupo Araras sobrepostos aos diamictitos (Babinski et al., 2006). 


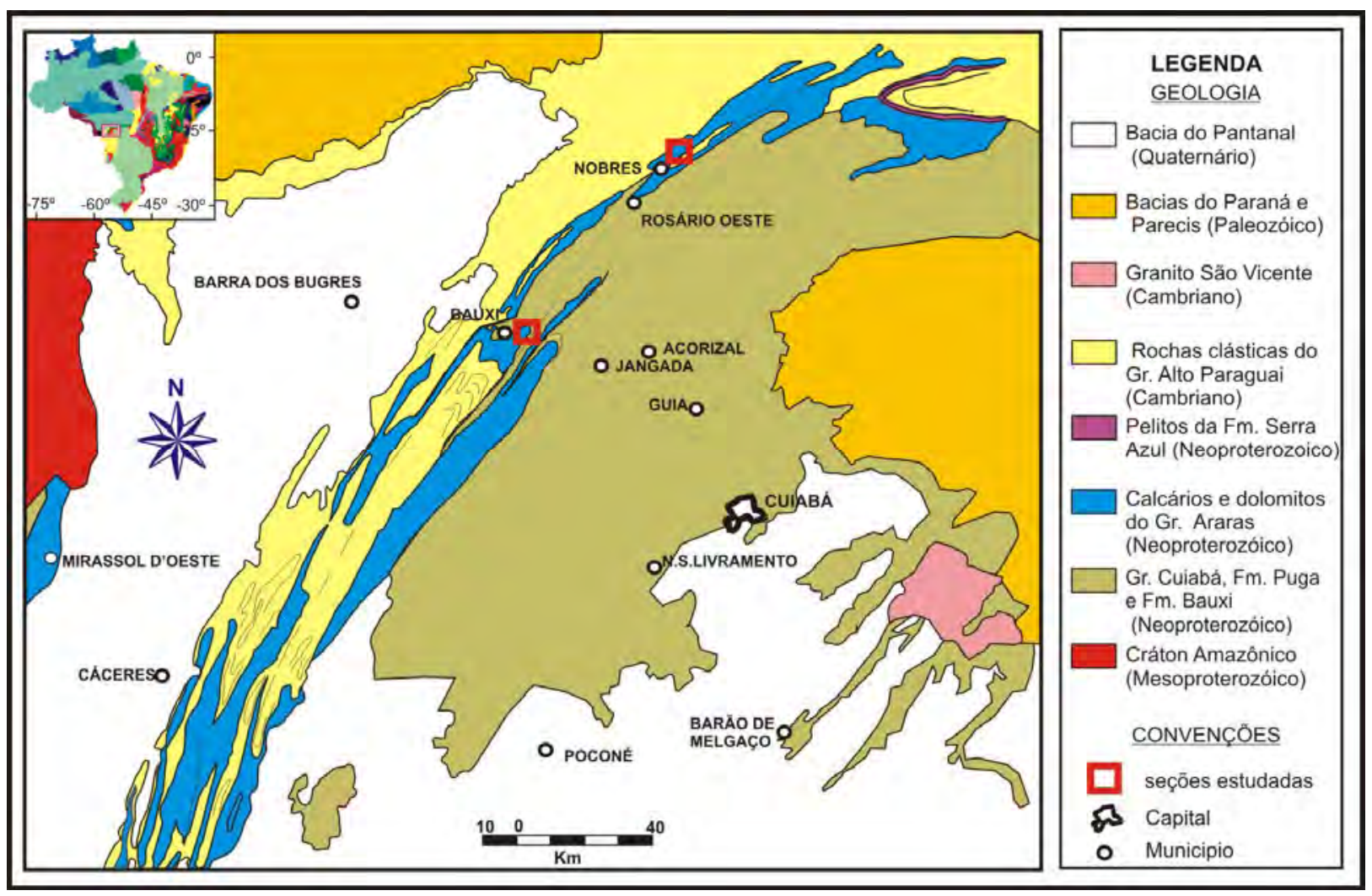

Figura 1. Mapa da geologia regional com a localização das seções estudadas, modificado de Alvarenga (1988).

\section{Grupo Araras}

As rochas da Formação Puga são sobrepostas por cerca de $1300 \mathrm{~m}$ de carbonatos do Grupo Araras, que foi dividido em quatro formações por Nogueira \& Riccomini (2006). A Formação Mirassol d'Oeste representa os carbonatos de capa, compostos por dolomitos róseos, contendo estruturas estromatolíticas, mega ripples, tubestones e leques de pseudomorfos de aragonita. A Formação Guia recobre a Formação Mirassol d'Oeste, no Domínio Cratônico, e a Formação Puga, no Domínio Tectônico Externo. Sua composição abrange aproximadamente $250 \mathrm{~m}$ de calcário e marga laminados, com intercalações de brechas, interpretados como ambiente de plataforma profunda a talude. A Formação Serra do Quilombo é composta de brechas dolomíticas cimentadas por calcita depositadas na plataforma. A Formação Nobres encerra o grupo com cerca de $600 \mathrm{~m}$ de dolomitos de plataforma rasa a planície de maré (Figura 2). 


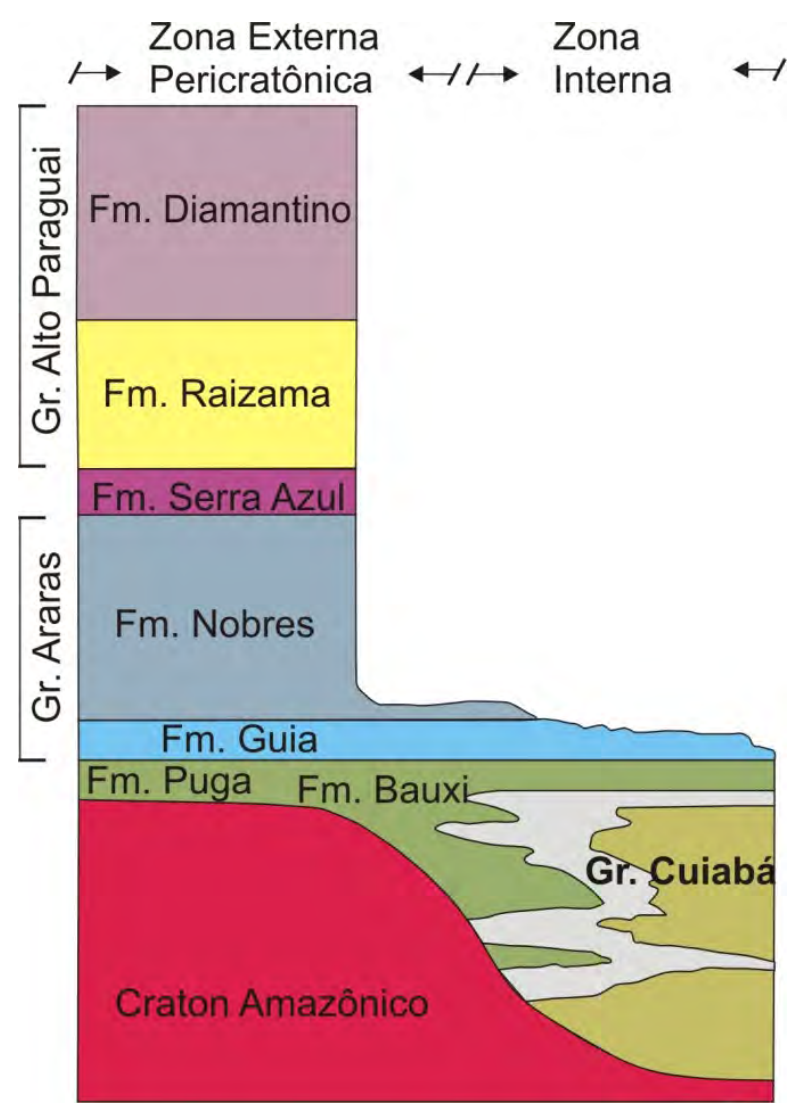

Figura 2. Coluna estratigráfica da Faixa Paraguai, incluindo a Formação Serra Azul (modificada de Alvarenga, 1988).

\section{Formação Serra Azul}

Sobreposta ao Grupo Araras (Figura 2), a Formação Serra Azul (Alvarenga et al., 2007; Figueiredo et al., 2008) é composta por cerca de $70 \mathrm{~m}$ diamictito maciço seguidos por $200 \mathrm{~m}$ de pelitos laminados (Figueiredo et al., 2008), com ocorrência de carbonatos lenticulares e arenitos finos contendo laminação ondulada (hummocky) em camadas com espessamento e aumento da freqüência para o topo. Os diamictitos apresentam-se maciço a pobremente estratificado, com abundante matriz silto-argilosa vermelha, contendo clastos variegados na composição (carbonatos, cherts, quartzo, arenitos, quartzitos, rochas graníticas, máficas e metamórficas), tamanho (grânulo a matacão) e forma, dispersos na matriz. Foram encontrados clastos facetados e estriados.

\section{RESULTADOS}

Ao todo foram analisadas 25 amostras para obtenção das composições isotópicas de $\mathrm{Pb}$ (Tabela 1). Destas, 9 correspondem aos calci-mudstones rítmicos e negros do topo da Formação Guia, coletados na pedreira Copacel II, e 16 aos calcários 
puros e claros pertencentes à Formação Serra Azul, coletados em dois afloramentos distintos, um na região de Bauxi e outro na região de Nobres.

Tabela 1. Tabela com as razões isotópicas de $\mathrm{Pb}$ obtidas para os calcários das formações Guia e Serra Azul.

\begin{tabular}{|c|c|c|c|c|c|c|c|}
\hline & AMOSTRA & ${ }^{206} \mathrm{~Pb} /{ }^{204} \mathrm{~Pb}$ & erro $^{1}$ & ${ }^{207} \mathrm{~Pb} /{ }^{204} \mathrm{~Pb}$ & erro $^{1}$ & ${ }^{208} \mathrm{~Pb} /{ }^{204} \mathrm{~Pb}$ & erro $^{1}$ \\
\hline \multirow{7}{*}{ 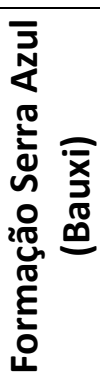 } & BX03 & 27.545 & 0.015 & 16.233 & 0.015 & 38.852 & 0.015 \\
\hline & BX07 & 29.629 & 0.023 & 16.349 & 0.025 & 40.603 & 0.024 \\
\hline & BX08 & 27.774 & 0.027 & 16.247 & 0.028 & 38.882 & 0.028 \\
\hline & $\mathrm{B} \times 12$ & 32.344 & 0.038 & 16.499 & 0.037 & 39.375 & 0.038 \\
\hline & $\mathrm{B} \times 16$ & 52.763 & 0.023 & 17.760 & 0.024 & 41.561 & 0.024 \\
\hline & $\mathrm{B} \times 20$ & 108.527 & 0.031 & 21.057 & 0.032 & 42.308 & 0.031 \\
\hline & $\mathrm{B} \times 21$ & 86.282 & 0.038 & 19.763 & 0.038 & 42.334 & 0.038 \\
\hline \multirow{10}{*}{ 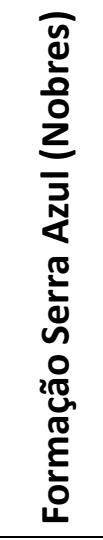 } & NB27 & 36.043 & 0.014 & 16.775 & 0.016 & 39.302 & 0.019 \\
\hline & NB29A & 25.766 & 0.010 & 16.152 & 0.009 & 39.541 & 0.010 \\
\hline & NB29B & 25.753 & 0.011 & 16.143 & 0.012 & 39.761 & 0.013 \\
\hline & SA19C & 32.750 & 0.045 & 16.519 & 0.045 & 39.604 & 0.045 \\
\hline & SA19D & 23.775 & 0.023 & 16.041 & 0.025 & 38.968 & 0.014 \\
\hline & SA19E & 23.158 & 0.008 & 15.984 & 0.010 & 38.983 & 0.008 \\
\hline & SA19F & 22.358 & 0.013 & 15.939 & 0.014 & 38.891 & 0.014 \\
\hline & SA19G & 26.712 & 0.108 & 16.129 & 0.118 & 39.842 & 0.108 \\
\hline & $\mathrm{SA} 19 \mathrm{H}$ & 27.390 & 0.009 & 16.252 & 0.010 & 40.731 & 0.009 \\
\hline & SA19I & 25.487 & 0.036 & 16.135 & 0.036 & 39.157 & 0.034 \\
\hline \multirow{9}{*}{ 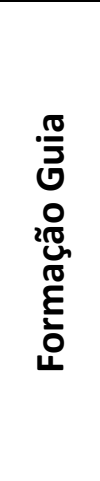 } & SA45E & 64.234 & 0.094 & 18.255 & 0.105 & 39.359 & 0.093 \\
\hline & SA45F & 75.810 & 0.227 & 19.039 & 0.186 & 43.510 & 0.228 \\
\hline & SA45G & 67.358 & 0.101 & 18.647 & 0.106 & 42.831 & 0.100 \\
\hline & SA45H & 45.258 & 0.112 & 17.330 & 0.112 & 44.165 & 0.108 \\
\hline & SA45I & 149.808 & 0.446 & 23.214 & 0.447 & 37.883 & 0.436 \\
\hline & SA45J & 70.355 & 0.027 & 18.839 & 0.028 & 42.766 & 0.027 \\
\hline & SA45K & 43.760 & 0.351 & 17.078 & 0.379 & 42.871 & 0.358 \\
\hline & SA45L1 & 37.832 & 0.025 & 16.890 & 0.025 & 44.933 & 0.025 \\
\hline & SA45L2 & 76.065 & 0.423 & 19.150 & 0.392 & 40.208 & 0.420 \\
\hline
\end{tabular}

As razões isotópicas de $\mathrm{Pb}$ obtidas nas rochas da Formação Guia mostraram um bom espalhamento, porém com erros analíticos altos. As razões variam ao longo da estratigrafia ritmicamente, de maneira independente do conteúdo de matéria orgânica ou das estruturas sedimentares observadas. As razões ${ }^{206} \mathrm{~Pb} /{ }^{204} \mathrm{~Pb}$ para estes calcimudstones rítmicos variaram entre 37,832 a 149,808 , enquanto que as razões ${ }^{207} \mathrm{~Pb} /{ }^{204} \mathrm{~Pb}$ variaram entre 16,890 e 23,214 . Apenas três análises apresentaram erros baixos (entre 0,025 e 0,028), sendo que as demais apresentaram erros altos (entre 
0,094 e 0,447). Ao serem plotados no diagrama ${ }^{207} \mathrm{~Pb} /{ }^{204} \mathrm{~Pb}$ versus ${ }^{206} \mathrm{~Pb} /{ }^{204} \mathrm{~Pb}$, fornecem uma idade isocrônica de $580 \pm 77$ Ma (MSWD = 0,75).

Os calcários da Formação Serra Azul da região de Nobres guardam a anomalia negativa de $\delta^{13} \mathrm{C}(-6 \%$ ) e possuem razões isotópicas de $\mathrm{Pb}$ menos radiogênicas que aquelas observadas nos carbonatos da Formação Guia. As razões ${ }^{206} \mathrm{~Pb} /{ }^{204} \mathrm{~Pb}$ obtidas variam de 22,358 a 36,043, enquanto que as razões ${ }^{207} \mathrm{~Pb} /{ }^{204} \mathrm{~Pb}$ variam de 15,939 a 16,775. Apesar de nove das dez amostras analisadas possuírem erros baixos (< 0,045), estas forneceram uma idade ${ }^{207} \mathrm{~Pb}-{ }^{206} \mathrm{~Pb}$ isocrônica com alto erro (639 $\pm 89 \mathrm{Ma}$; MSWD 0,40). As amostras da mesma formação, coletadas próximo à cidade de Bauxi, mostraram-se mais radiogênicas, com um bom espalhamento e erros analíticos baixos. O afloramento estudado apresenta duas camadas de calcário intercaladas com pelitos e arenitos, em posição estratigráfica acima do afloramento estudado na região de Nobres, sendo as 2 amostras mais radiogênicas localizadas no topo. Estas duas amostras apresentaram razões ${ }^{206} \mathrm{~Pb} /{ }^{204} \mathrm{~Pb}$ de 86,282 e 108,527 , e ${ }^{207} \mathrm{~Pb} /{ }^{204} \mathrm{~Pb}$ de 19,763 e 21,057. As demais amostras apresentaram razões ${ }^{206} \mathrm{~Pb} /{ }^{204} \mathrm{~Pb}$ entre $27,545 \mathrm{e}$ 52,763 , e razões ${ }^{207} \mathrm{~Pb} /{ }^{204} \mathrm{~Pb}$ entre 16,233 e 17,760 . A idade isocrônica ${ }^{207} \mathrm{~Pb}-{ }^{206} \mathrm{~Pb}$ obtida nestas 7 amostras foi de $596 \pm 26$ Ma (MSWD 0,33; Figura 3a).

Se forem consideradas todas as amostras, de ambos os afloramentos da Formação Serra Azul, obtém-se uma isócrona Pb-Pb de $587 \pm 22$ Ma (MSWD 0,64; Figura 3b). Esta idade é pouco mais precisa devido ao bom espalhamento dos 17 pontos, que consideram as razões menos radiogênicas do afloramento de Nobres com as mais radiogênicas do afloramento de Bauxi. Embora o afloramento de Bauxi seja considerado de sedimentação imediatamente após o de Nobres, não é recomendado que se utilize amostras de afloramentos distintos, aumentando o risco de construir uma isócrona com amostras não co-genéticas. 

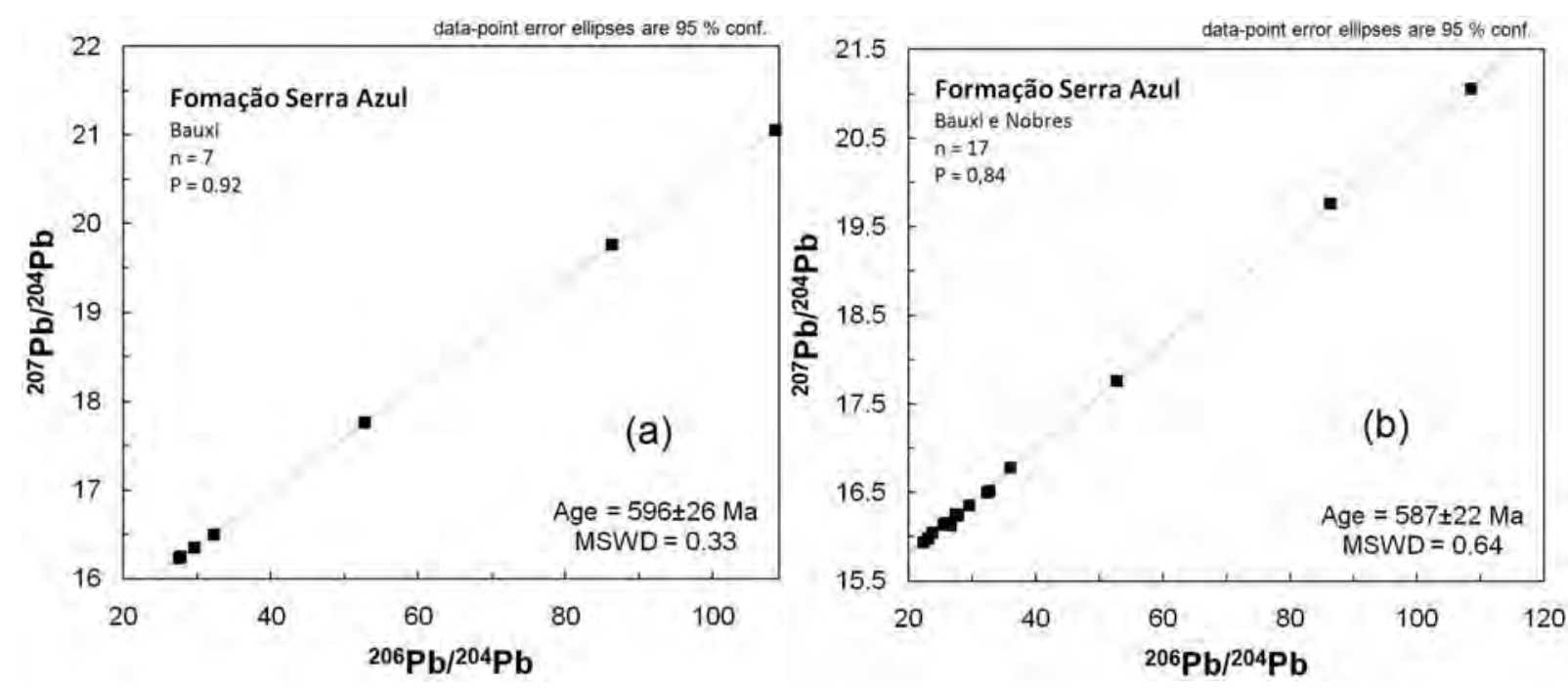

Figura 3. Diagramas ${ }^{207} \mathrm{~Pb} /{ }^{204} \mathrm{~Pb}$ versus ${ }^{206} \mathrm{~Pb} /{ }^{204} \mathrm{~Pb}$ da Formações Serra Azul. As idades isocrônicas foram calculadas com auxílio do suplemento Isoplot (Ludwig, 2009), versão Beta para Microsoft Excel 2007.

\section{DISCUSSÃO E CONCLUSÕES}

De acordo com Jahn \& Cuvellier (1994), a razão U-Pb em carbonatos antigos tende a diminuir amplamente, porém muitas rochas carbonáticas possuem razões isotópicas de $\mathrm{Pb}$ suficientemente radiogênicas para pemitir a datação pela metodogia isotópica 207Pb-206Pb. Estudos realizados por Jones et al. (1995) mostram que as razões isotópicas de $\mathrm{Pb}$ dificilmente são alteradas pela diagênese, sendo as idades isocrônicas $\mathrm{Pb}-\mathrm{Pb}$ obtidas para calcários permianos, não deformados tectonicamente, correspondentes à idade de sedimentação. Neste contexto, os resultados obtidos nos carbonatos da Faixa Paraguai serão interpretados com cautela, sempre considerando a possibilidade de um sistema fechado desde sua sedimentação no ediacarano e de um sistema aberto ou reiniciado pelo Ciclo Brasiliano, já que os fluídos tectônicos podem alterar sensivelmente as concentrações de elementos traços, bem como variar a razão $\mathrm{U}-\mathrm{Pb}$.

As idades obtidas para a Formação Guia e para a Formação Serra Azul na região de Nobres, apresentaram erros bastante altos. No caso das amostras da Formação Guia, os erros analíticos obtidos para as razões isotópicas de $\mathrm{Pb}$ são bastante altos, dificultando a obtenção de uma isócrona mais ajustada. Em relação à amostras da Formação Serra Azul, os erros analíticos apresentados para as razões isotópicas de $\mathrm{Pb}$ são razoavelmente baixos, porém os pontos apresentam pouco 
espalhamento e não permitiu o bom ajuste da reta e conseqüente idade 207Pb-206Pb. Esta limitação na obtenção da idade isocrônica pode estar relacionado à composição isotópica inicial de Pb não ter sido homogênea (Jahn \& Cuvellier, 1994), devido à recristalização diagenética irregular (Sarangi et al., 2007) ou à contaminação do carbonato com $\mathrm{U}$ e/ou $\mathrm{Pb}$ proveniente dos sulfetos contidos nos calcários ou dos silicatos adjacentes (Kaurova, 2010). Desta forma, o significado destas idades é incerto, podendo representar tanto a idade de sedimentação, quanto a da deformação destas rochas, que pode ter provocado a abertura do sistema $207 \mathrm{~Pb}-206 \mathrm{~Pb}$, alterando a idade mínima de deposição.

De qualquer maneira, a idade 207Pb-206Pb de $627 \pm 32 \mathrm{Ma}$ (Babinski et al., 2006), obtida nos carbonatos de capa da Formação Mirassol d'Oeste, continua sendo a melhor estimativa para a glaciação Puga e sua correlação com a Glaciação Marinoana de $635 \mathrm{Ma}$ (Hoffmann et al., 2004; Condon et al., 2005).

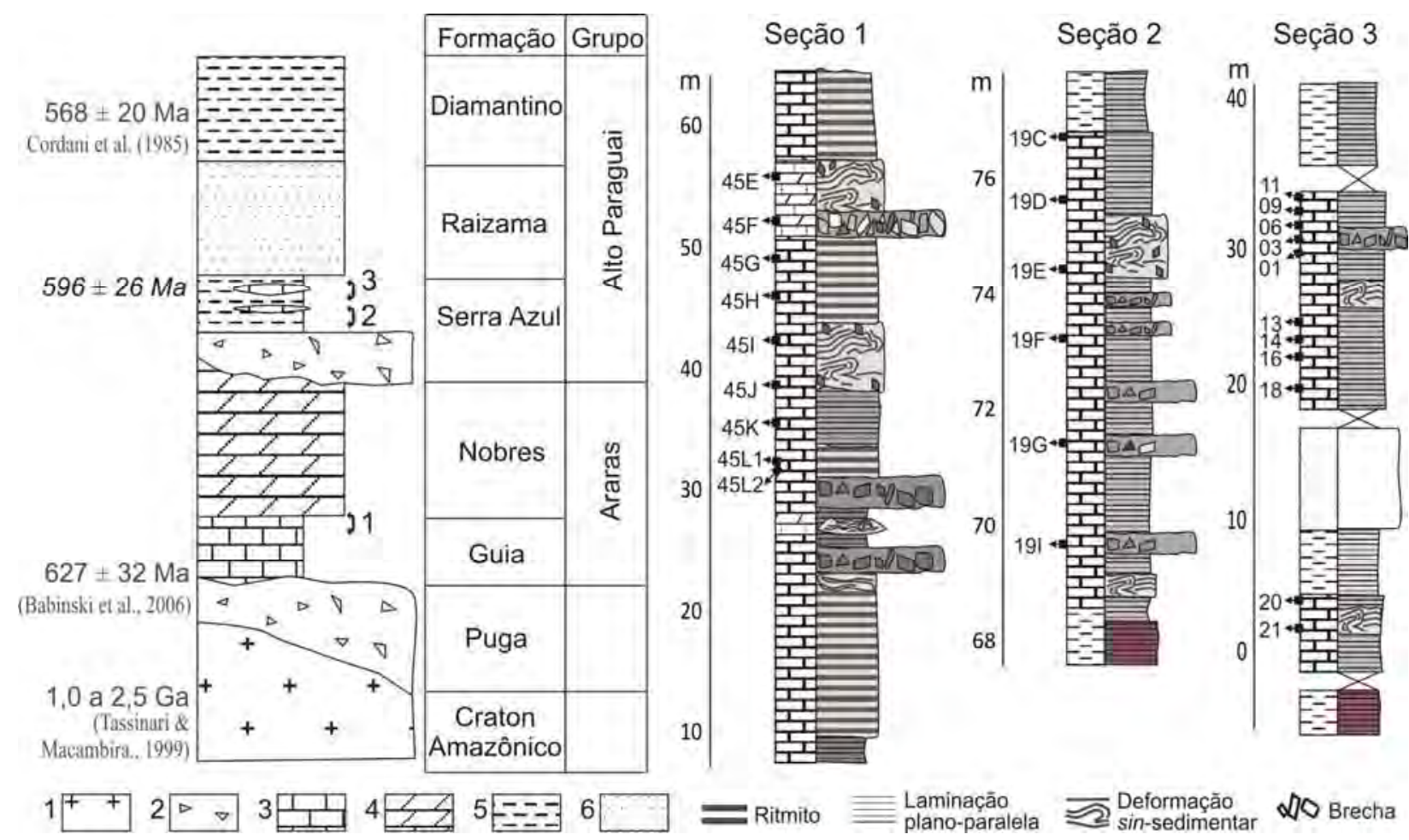

Figura 4. Litoestratigrafia da Faixa Paraguai: 1) embasamento cratônico, 2) diamictito, 3) calcário, 4) dolomito, 5) pelito e 6) arenito. À direita, detalhe das seções estudadas, indicandose a posição estratigráfica das amostras analisadas. 
Por outro lado, a idade obtida para o segundo intervalo carbonático da Formação Serra Azul (região de Bauxi) possui um erro menor, sendo interpretada como a idade de deposição para estas rochas. Considerando seu erro, é possível estabelecer uma idade de deposição mínima de 570 Ma e máxima de 622 Ma. Esta idade mínima é coerente com um sistema U-Pb não afetado pela tectônica compressiva da Faixa Paraguai, evidenciada pela idade Ar-Ar de resfriamento em biotitas de $541 \pm 0,7 \mathrm{Ma}$ (Geraldes et al., 2008) e intrusão pós-colisional do granito São Vicente há $521 \pm 8 \mathrm{Ma}$ (idade U-Pb; Ferreira, 2009). Isso reforça a aplicabilidade do sistema U-Pb também em carbonatos deformados, para a obtenção de idades de sedimentação (Ovchinnikova et al., 2007). Já a idade máxima confirma a deposição da Formação Serra Azul após a Glaciação Marinoana, aumentando a possibilidade dos diamictitos glaciais serem correlatos da Glaciação Gaskiers de 582 Ma (Bowring et al., 2003).

Neste trabalho, o método $\mathrm{Pb}-\mathrm{Pb}$ em carbonatos mostrou-se aplicável também nos calcários dobrados das sucessões carbonáticas da Faixa Paraguai, possibilitando a obtenção de idades coerentes com a história geológica destas rochas. No entanto, o erro alto das idades obtidas para as formações Guia e Serra Azul na região de Nobres, devido aos altos erros analíticos e às interferências nos sistemas $\mathrm{U}-\mathrm{Pb}$, dificultam as interpretações geocronológicas dos processos geológicos ocorridos. Este problema pode ser amenizado com análise de uma quantidade maior de amostras.

\section{REFERÊNCIAS BIBLIOGRÁFICAS}

Alvarenga, C.J.S., 1988. Turbiditos e a glaciação do final do Proterozóico Superior no Cinturão Paraguai, Mato Grosso. Revista Brasileira de Geociências, 18: 323-327.

Alvarenga, C.J.S.de, Santos, R.V., Dantas, E.L. 2004. C-O-Sr isotopic stratigraphy of cap carbonates overlying Marinoan-age glacial diamictites in the Paraguay Belt, Brazil. Precambrian Research, 131:1-21.

Alvarenga, C.J.S.de, Figueiredo, M.F., Babinski, M., Pinho, F.E.C. 2007. Glacial diamictites of Serra Azul Formation (Ediacaran, Paraguay Belt): evidence of the Gaskiers glacial event in Brazil. Journal of South American Earth Science, 23: 236241.

Babinski, M., Chemale Jr., F., Schmus, W.V., 1995. The Pb/Pb age of the Minas Supergroup carbonate rocks, Quadrilátero Ferrífero, Brazil. Precambrian Research, 72: $235-245$.

Babinski, M., Van Schmus, W.R. Chemale Jr., F., 1999. Pb-Pb dating and Pb isotope geochemistry of Neoproterozoic carbonates rocks from the São Francisco Basin, 
Brazil: implications for the mobility of $\mathrm{Pb}$ isotopes during tectonism and metamorfism. Chemical Geology, 160: 175-199.

Babinski M., Vieira, L.C., Trindade, R.I.F. 2007. Direct dating of the Sete Lagoas cap carbonate (Bambui' Group, Brazil) and implications for the Neoproterozoic glacial events. Terra Nova, 19:401-406.

Babinski, M., Trindade, R.I.F., Alvarenga, J.C., Boggini, P.C., Liu, D., Santos, R.V., 2006. Geochronological constrains on the neoproterozóic glaciations in Brazil. Snowball Earth Conference, Ascona, Switzerland.

Barfod, G.H., Albarede, F., Knoll, A.H., Xiao, S., Télouk, P., Frei, R., Baker, J. 2002. New Lu-Hf and Pb-Pb age consraints on the earliest animal fossils. Earth Planetary Science Letters, 201: 203-212.

Barros, A.M., Silva, R.H., Cardoso, O.R.F.A., Freire, F.A., Souza Júnior, J.J.S, Rivetti, M., Luz, D.S., Palmeira, R.C.B., Tassinari, C.C.G., 1982. Folha SD 21 Cuiabá; Geologia. Projeto RADAM BRASIL, Levantamento de Recursos Naturais. Ministério das Minas e Energia, Rio de Janeiro, 26:25-175.

Bingen, B., Griffin, W.L., Torsvik, T.H., Saeed, A. 2005. Timing of late Neoproterozoic glaciation on Baltica constrained by detrital geochronology in the Hedmark Group, southeast Norway. Terra Nova, 17: 593-596.

Bowring, S., Myrow, P., Landing, E., Ramezani, J., Grotzinger, J. 2003. Geocronological constraints on terminal Proterozoic events and the rise of metazoans. Geophysical Research Abstracts, 5: 213-219.

Brasier, M., McCarron, G., Tucker, R., Leather, J., Allen, P., Shields, G. 2000. New UPb zircon dates for the Neoproterozoic Ghubrah glaciation and for the top of the Huqf Supergroup, Oman Geology, 28:175-178.

Condon, D., Zhu, M., Bowring, S., Wang, W., Yang, A., Jin, Y., 2005. U-Pb ages from the Neoproterozoic Doushantuo Formation, China. Science 308: 95-98.

Eyles, N., Eyles, C. 1989. Glacially-influenced deep-marine sedimentation of the Late Precambrian Gaskiers Formation, Newfoundland, Canada. Sedimentology, 36: 601620.

Ferreira, C. O. 2009. A extensão do arco magmático de Goiás ao longo do Lineamento Transbrasiliano: Estudo baseado na aplicação dos métodos U-Pb e Lu-Hf por LAMC-ICP-MS. Dissertação de mestrado, Universidade de Brasília, 72p.

Figueiredo, M.F., Babinski, M., Alvarenga, C.J.S., Pinho, F.E.C. 2008. Nova unidade litoestratigráfica registra glaciação ediacarana: Formação Serra Azul. Revista Geologia-USP, 8: 65-75.

Fölling, P.G., Zartman, R.E. and Frimmel, H.E., 2000. A novel approach to double-spike $\mathrm{Pb}-\mathrm{Pb}$ dating of carbonate rocks: examples from Neoproterozoic sequences in southern Africa. Chemical Geology, 171: 97-122.

Geraldes, M.C., Tassinari, C.C.G., Babinski, M., Martinelli, C.D., Iyer, S.S., Barboza, E.S., Pinho, F.E.C., Onoe. A.T. 2008. Isotopic evidence for the Late Brasiliano (500-550 Ma) ore-forming mineralization of the Araés Gold Deposit, Brazil. International Geology Review, 50: 177-190.

Halverson, G.P., Maloof, A.C., Hoffman, P.F., 2004. The Marinoan glaciation (Neoproterozoic) in northeast Svalbard. Basin Research, 16: 297-324. 
Halverson, G.P., Hoffman, P.F., Schrag, D.P., Maloof, A.C., Rice, A.H., 2005. Towards a Neoproterozoic composite carbon isotope record. Geological Society of America Bulletin, 117:1181-1207.

Hoffman, P.F., Kaufman, A.J., Halverson, G.P., Schrag, D.P., 1998. A Neoproterozoic Snowball Earth. Science, 281:1342-1346.

Hoffman, P.F., Schrag, D.P., 2002. The snowball Earth hypothesis: testing the limits of global change. Terra Nova, 14:129-155.

Hoffmann, K.H., Condon, D.J., Bowring, S.A., Crowley, J.L., 2004. A U-Pb zircon date from the Neoproterozoic Ghaub Formation, Namibia: Constrains on Marinoan glaciation. Geology, 32: 817-820.

Jahn, B.-M., Cuvellier, $\mathrm{H} .$, 1994. $\mathrm{Pb}-\mathrm{Pb}$ and $\mathrm{U}-\mathrm{Pb}$ geochronology of carbonate rocks: an assessment. Chemical Geology, 115, 125-151.

Jones,C.E., Halliday, A.N., Lohmann, K.C. 1995. The impact of diagenesis on hightprecision U-Pb dating of ancient carbonates: An example from the Late Permian of New Mexico. Earth and Planetary Science Letters, 134: 409-423.

Kaurova, O.K., Ovchinnikova, G.V., Gorokhov, I.M. 2010. U-Th-Pb Systematics of Precambrian Carbonate Rocks: Dating of the Formation and Transformation of Carbonate Sediments. Stratigraphy and Geological Correlation, 18: 252-268.

Kirschvink, J.L., 1992. Late Proterozoic low-latitude glaciation: The snowball Earth. In: The Proterozoic Biosphere (J.W. Schopf and C. Klein, eds.), Cambridge University Press, Cambridge, pp 51-52.

Ludwig, K.R., 2009. User's manual for Isoplot Beta Version for Microsoft Excel 2007. A geochronological toolkit for Microsoft Excel. Berkeley Geochronological Center Special Publication 1a, 47p., Berkeley, USA.

Maciel, P., 1959. Tilito Cambriano (?) no Estado de Mato Grosso. Boletim da Sociedade Brasileira de Geologia, 81:31-39.

McFadden, K.A., Huang, J., Chu, X., Jiang, G., Kaufman, A.J., Zhou, C., Yuan, X., Xiao, S. 2008. Pulsed oxidation and biological evolution in the Ediacaran Doushantuo Formation. Proceedings of the National Academy of Sciences, 105: 3197-3202.

Moorbath, S., Taylor, P.N., Orpen, J.L., Treloar, P., Wilson, J.F., 1987. First direct radiometric dating of Archean stromatolite limestone. Nature, 326: 865-867.

Myrow, P.M., Kaufman, A.J., 1999. A newly discovered cap carbonate above Varanger age glacial deposits in Newfoundland, Canada. Journal of Sedimentary Research, 69:784-793.

Nogueira, A.C.R., Riccomini, C., Sial, A.N., Moura, C.A.V., Fairchild, T.R. 2003. Softsediment deformation at the base of the Neoproterozoic Puga cap carbonate (southwestern Amazon craton, Brazil): Confirmation of rapid icehouse to greenhouse transition in snowball Earth. Geology, 31: 613-616.

Nogueira A.C.R., Riccomini C. 2006. O Grupo Araras (Neoproterozóico) na parte norte da Faixa Paraguai e sul do Cráton Amazônico, Brasil. Revista Brasileira de Geociências, 36:623- 640. 
Ovchinnikova, G.V., Kuznetsov, A.B., Melezhik, V.A., 2007. Pb-Pb age of Jatulian carbonate rocks: The Tulomozero Formation of Southheast Karelia. Stratigraphy and Geological Correlation, 15: 359.

Preiss, W.V. 2000, The Adelaide Geosyncline of South Australia and its significance in Neoproterozoic continental reconstruction. Precambrian Resesearch, 100: 21-63.

Ribeiro Filho, W., Luz, J.S., Abreu, W., R., 1975. Projeto Serra Azul; relatório final. Departamento Nacional de Produção Mineral e Companhia de Pesquisa de Recursos Minerais, Relatório do Arquivo Técnico da Divisão de Geologia Mineral, volume 1.

Sarangi, S., Gopalan, K., Srinivasan, R. 2007. Small scale sampling for Pb-Pb dating of marbles: Example from the Sargur supracrustal rocks, Dharwar Craton, South India. Precambrian Research, 152: 83-91.

Sovetov, J. 2008. Marinoan glaciation in the Siberian craton: Locality, erosional forms, deposits and constrains to age. $33^{\text {rd }}$ International Geological Congress, Oslo, Abstracts CGC-04, CD-ROM.

Trindade, R.I.F., Font, E., D’Agrella-Filho, M.S., Nogueira, A.C.R., Riccomini, C., 2003. Low-latitude and multiple geomagnetic reversals in the Neoproterozoic Puga cap carbonate of Amazonia. Terra Nova, 15: 441-446.

\title{
5.2. ARTIGO 5: PROVENIÊNCIA DAS ROCHAS SEDIMENTARES PLATAFORMAIS DA FAIXA PARAGUAI NORTE
}

\author{
Milene F. Figueiredo e Marly Babinski
}

Instituto de Geociências, Universidade de São Paulo (USP), São Paulo, SP - Brasil.

E-mail: milene.figueiredo@gmail.com, babinski@usp.br

\section{RESUMO}

As rochas da Faixa Paraguai registram a ocorrência de uma glaciação criogeniana e outra ediacarana, separadas por uma espessa plataforma carbonática, que registra anomalias biogeoquímicas na água do mar ediacarano. Estas rochas foram depositadas na margem sudeste do Craton Amazônico entre a quebra do paleocontinente Rodínia e a colagem do Gondwana. O preenchimento desta bacia precursora é dinâmico em função das condições paleoclimáticas e do contexto tectônico, podendo provocar a variação de rochas-fonte ao longo da estratigrafia. No 
entanto, são raros os estudos de proveniência realizados nas rochas sedimentares da Faixa Paraguai.

Neste trabalho são apresentadas idades modelo Sm-Nd em rochas sedimentares terrígenas e idades K-Ar obtidas nos clastos vulcânicos recuperados do diamictito glacial ediacarano. As sucessões estudadas se encontram no domínio tectônico externo do extremo norte da Faixa Paraguai, Estado de Mato Grosso, e correspondem à zona plataformal e peri-plataformal da bacia precursora. Os clastos coletados da Formação Serra Azul forneceram idades K-Ar de 731 a $1167 \mathrm{Ma}$. As idades modelo obtidas nas rochas terrígenas variaram entre 1,5 e 2,2 Ga, com ${ }_{\varepsilon} \mathrm{Nd}_{(600 \mathrm{Ma})}$ de $-6,4 \mathrm{a}-14,5$. Foi identificada uma co-variação entre as idades modelo e o nível relativo do mar, com idades mais antigas associadas a ambientes mais profundos. As rochas estudadas sugerem o transporte de sedimentos provenientes das províncias mais proximais do Craton Amazônico e de fontes criogenianas ainda não conhecidas no paleocontinente.

\section{INTRODUÇÃO}

Os Elementos Terras Raras Sm e Nd são altamente insolúveis em água, de forma que o intemperismo tem um efeito muito pequeno sobre as composições destes elementos em sedimentos clásticos (Elderfield \& Greaves, 1982). Assim, os sedimentos gerados da alteração de determinada rocha mantém suas razões isotópicas originais, podendo-se utilizá-las no cálculo da idade modelo. Como é comum uma bacia sedimentar ser alimentada por mais de uma fonte, as razões isotópicas de Sm e $\mathrm{Nd}$ obtidas para os sedimentos corresponderão a uma média intermediária das diversas fontes, fornecendo uma idade $\mathrm{T}_{\mathrm{DM}}$ de mistura.

Neste trabalho, rochas detríticas da zona plataformal da Faixa Paraguai Norte foram analisadas pelo método $\mathrm{Sm}-\mathrm{Nd}$, sendo alguns clastos ígneos datados pelo método K-Ar. Estas rochas são compostas de diamictitos (matriz e clastos), pelitos e arenitos neoproterozoicos, pertencentes às formações Puga, Serra Azul e Raizama. Este estudo possui a finalidade de identificar as possíveis fontes e as variações na sua contribuição, de acordo com a transição entre os sistemas deposicionais reinantes e o início da tectônica atuante no sudeste do Craton Amazônico durante o fim do Ciclo Brasiliano. 


\section{CONTEXTO GEOLÓGICO}

A Faixa Paraguai Norte está geologicamente situada na borda sudeste do Craton Amazônico, como um traçado convexo para SE (Figura 1). É composta de rochas sedimentares depositadas numa margem passiva durante o Neoproterozoico e posteriormente dobradas pela Orogênese Brasiliana.

$\mathrm{Na}$ zona plataformal e peri-plataformal, encontra-se uma sucessão, da base para o topo de: i) diamictitos glaciais de matriz argilo-arenosa (Formação Puga; Alvarenga e Trompette, 1992) de idade criogeniana (Nogueira et al., 2003); ii) carbonatos marinhos (Grupo Araras) com calcários de talude a plataforma profunda e dolomitos de plataforma rasa a planície de maré (Nogueira \& Riccomni., 2006); iii) diamictitos glaciais de matriz síltica de idade ediacarana (Formação Serra Azul, Grupo Alto Paraguai; Figueiredo et al., 2008); e iv) arenitos e pelitos deltaicos e de planície de maré (Formação Raizama, Grupo Alto Paraguai; Almeida, 1964). Acima desta sucessão, ocorrem os pelitos e arenitos molássicos da Formação Diamantino (Grupo Alto Paraguai; Hennies, 1966), que marcam a inversão tectônica da bacia. Este trabalho se concentra nas unidades terrígenas, excetuando-se a Formação Diamantino.

\section{RESULTADOS}

Foram realizadas análises isotópicas de $\mathrm{Sm}$ e $\mathrm{Nd}$ em 32 amostras de rochas sedimentares (Tabela 1), coletadas em três localidades distintas ao longo do lineamento leste-oeste da Faixa Paraguai, extremo norte deste cinturão de dobramentos, entre as cidades de Nobres e Planalto da Serra, MT. Idades radiométricas $\mathrm{K}$-Ar foram obtidas em clastos vulcânicos recuperados dos diamictitos da Formação Serra Azul, na região de Marzagão (Figura 1, Tabela 2). As idades Sm-Nd foram calculadas de acordo com o modelo de manto empobrecido (DePaolo, 1981) e os valores \&Nd apresentados foram calculados para $600 \mathrm{Ma}$. 

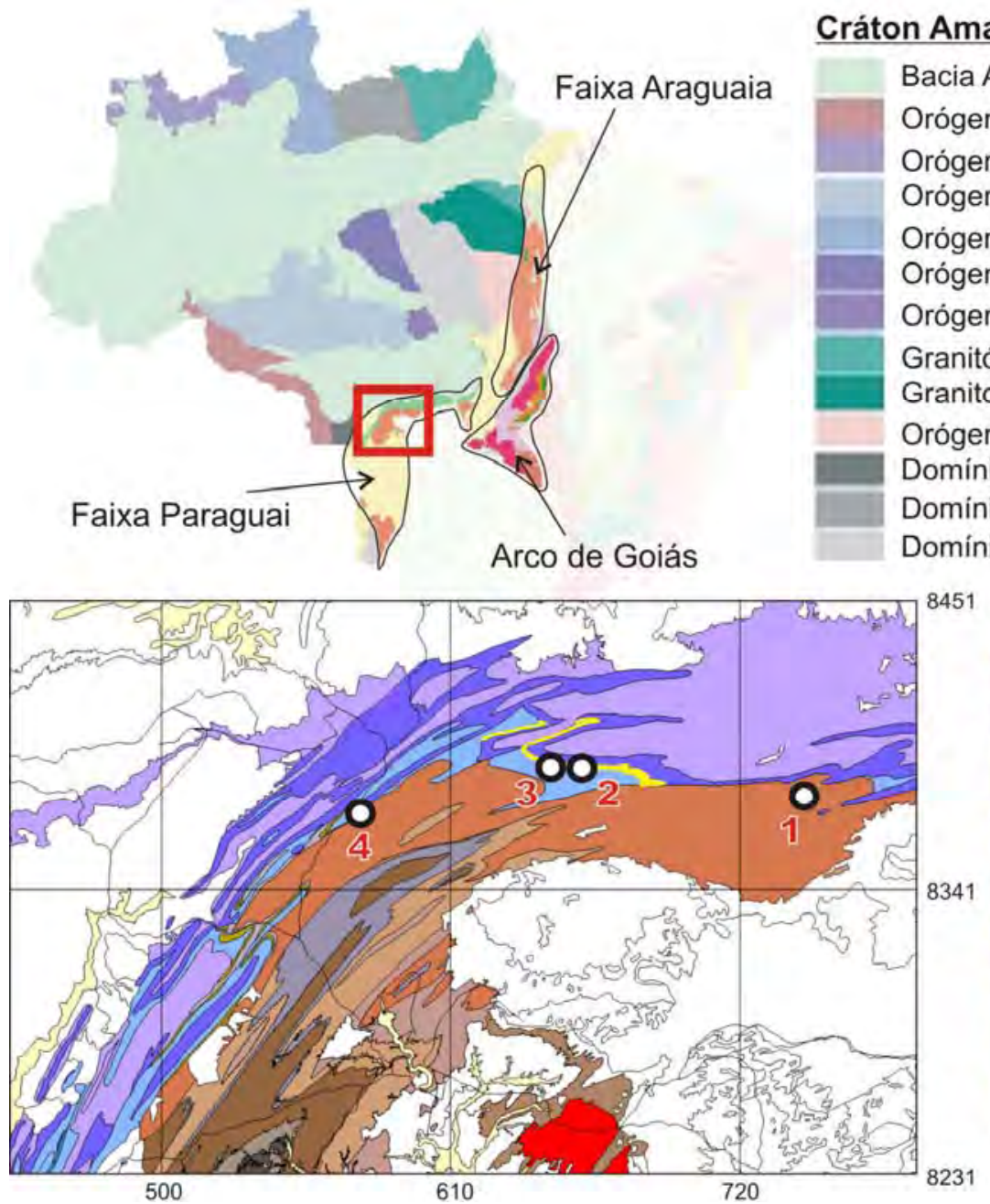

\section{Cráton Amazônico}

Bacia Amazonas (Fanerozoico)

Orógeno Sunsás (1.35-1.10 Ga)

Orógeno Rio Negro (1.81-1.55 Ga)

Orógeno Rondônia-Juruena

Orógeno Tapajós-Parima (2.02-1.88 Ga)

Orógeno Tapajós-Parima

Orógeno Tapajós-Parima

Granitóide-Greenstone

Granito-Greenstone (2.76-2.57 Ga)

Orógeno Rio Maria (3.0-2.82 Ga)

Dominio Jauru-Sta. Helena (1.79-1.40 Ga)

Dominio Curua-Mapuera

Domínio Iriri-Chingu

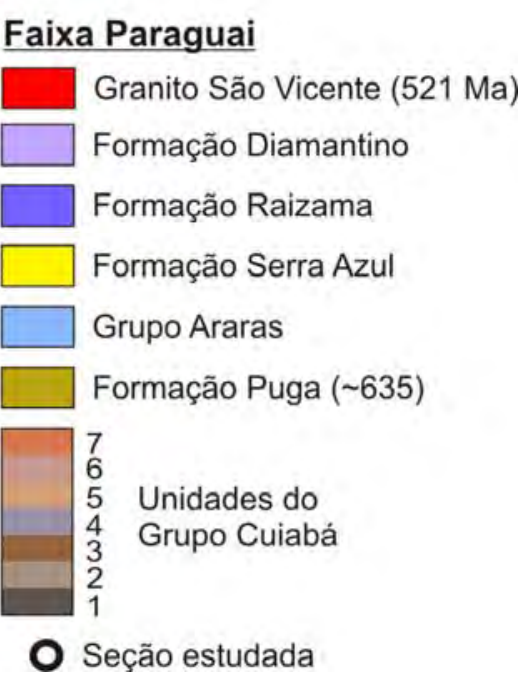

Figura 1. Mapa geológico de localização com destaque para o Cráton Amazônico (esquerda; Santos, 2003) e geologia da Faixa Paraguai com localização das seções estudadas (direita).

A Fm. Puga, amostrada nos arredores de Planalto da Serra, forneceu idades $T_{D M}$ de 1,5 a 1,8 Ga, com $\varepsilon N d$ entre - 6.5 e - 9 (Figura 2, Tabela 1). A idade mais jovem (1,5 Ga) encontra-se na porção intermediária desta formação e corresponde a um possível tufo vulcânico. As demais idades apresentam-se mais jovens em direção ao topo (seção 1, Figura 3).

A matriz dos diamictitos da Formação Serra Azul apresentou idades $T_{D M}$ entre 1,5 e 1,9 Ga ( $\varepsilon N d$ entre - 6,8 e - 8,6; Figura 2) para os diamictitos da região de Marzagão, com idades mais jovens em direção ao topo e uma brusca mudança para fontes mais antigas na última camada de diamictito (seções 2 e 3, Figura 3). Um clasto de arenito e dois de quartzito, recuperados deste diamictito, forneceram idades $\mathrm{T}_{\mathrm{DM}}$ de 1,8, 1,9 e 2,2 Ga ( $\varepsilon N d$ - 10,7 a - 14,5; Figura 2), respectivamente. Os clastos 
vulcânicos, compostos de um diabásio fino e dois riolitos, forneceram idades K-Ar de 1,04 Ga, 1,17 Ga e 731 Ma (Tabela 2), respectivamente. Na mesma região, os pelitos que sobrepõem estes diamictitos apresentaram idades $T_{D M}$ entre 1,8 e 1,9 Ga (seções 2 e 3, Figura 3), com $\varepsilon N d$ entre - 8,5 e - 9,3 (Figura 2).

Rochas da Formação Serra Azul, na região de Nobres, forneceram idades $T_{D M}$ de 1,6 Ga a 2,0 Ga ( $\varepsilon N d-6,5$ a - 8,7; Figura 2, Tabela 1) para os pelitos que recobrem o diamictito, que não foi observado nesse afloramento (seção 4, Figura 3).

As amostras da base da Formação Raizama apresentaram idades $T_{\mathrm{DM}}$ entre 1,6 e 1,9 Ga ( $\varepsilon \mathrm{Nd}-8,2$ a - 9,3; Figura 2, Tabela 1$)$ para a região de Planalto da Serra (seção 1, Figura 3), sendo que elas se tornam mais antigas em direção ao topo, com mudança brusca para fonte mais jovem na última camada amostrada. Na região de Marzagão, foram obtidas as mesmas idades $T_{D M}$, porém elas se tornam mais jovens gradualmente em direção ao topo. Na região de Nobres foi coletada apenas uma amostra de arcóseo, que forneceu uma idade $\mathrm{T}_{\mathrm{DM}}$ de 1,7 Ga (seção 4, Figura 3) e $\varepsilon N d$ de -8 (Figura 2, Tabela 1).

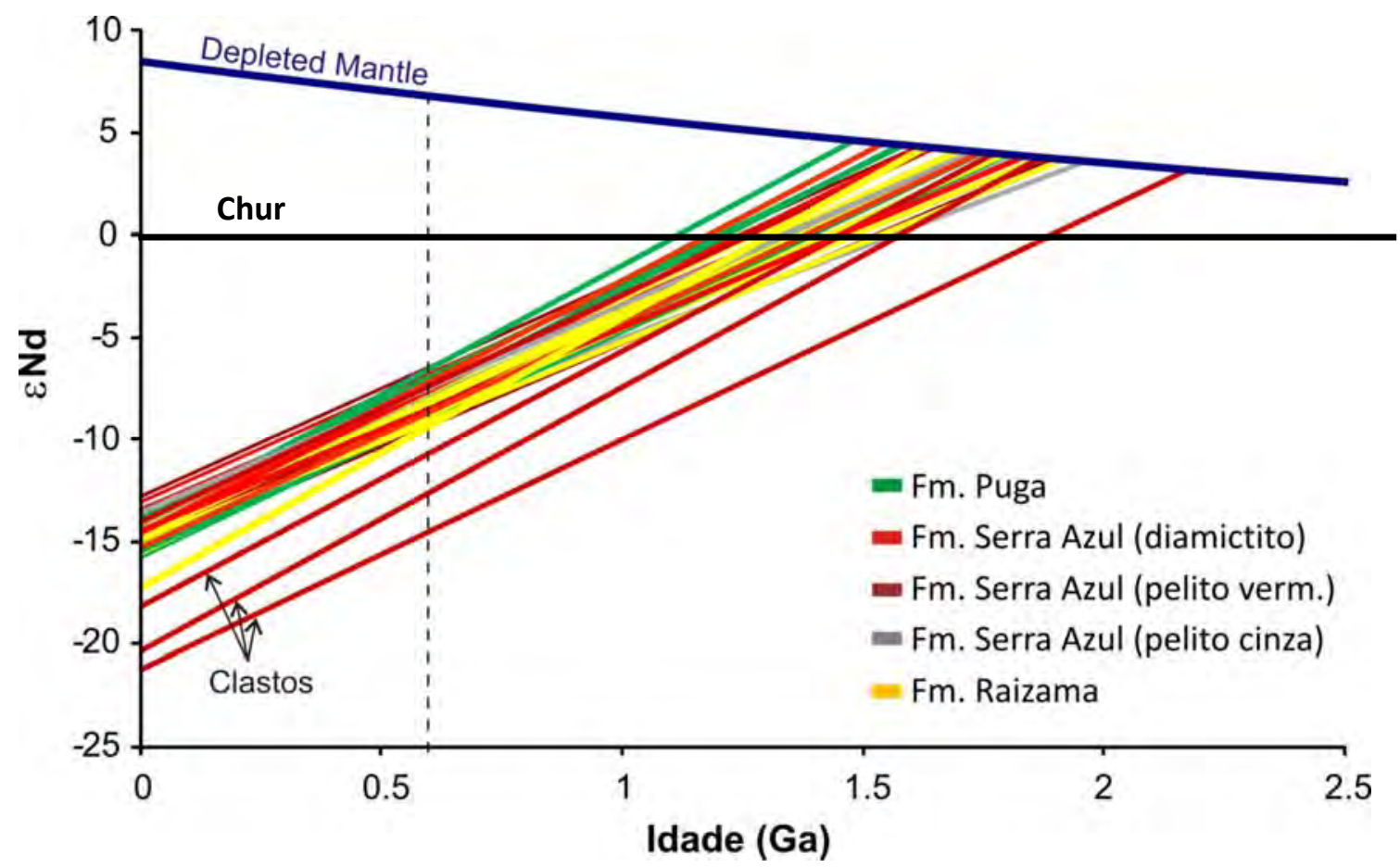

Figura 2. Idades modelo Sm-Nd para as rochas da Faixa Paraguai, distintas por unidade estratigráfica. 
Tabela 1. Idades modelo Sm-Nd obtidas em rochas sedimentares e K-Ar obtidas em clastos ígneos recuperados dos diamictitos da Formação Serra Azul

\begin{tabular}{|c|c|c|c|c|c|c|c|c|c|c|c|c|}
\hline & AMOSTRA & MATERIAL & $\begin{array}{c}\text { Sm } \\
(\mathrm{ppm})\end{array}$ & Nd (ppm) & ${ }^{147} \mathrm{Sm} /$ & Erro $(1 \sigma)$ & ${ }^{143} \mathrm{Nd} /{ }^{144} \mathrm{Nd}$ & Erro $(2 \sigma)$ & $\begin{array}{c}\mathrm{fSm} / \\
\mathrm{Nd}\end{array}$ & $\begin{array}{l}\mathrm{T}_{\mathrm{DM}} 1 \\
\text { (Ga) }\end{array}$ & $\varepsilon N d(0)$ & $\varepsilon_{(600 \mathrm{Ma})}$ \\
\hline \multirow{8}{*}{ 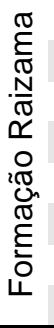 } & PS17 & Argilito & 11.062 & 62.935 & 0.1063 & .0006 & 0.511838 & 0.000011 & -0.46 & 1.7 & -15.61 & -8.69 \\
\hline & PS22B & Argilito & & & & & 0.511883 & & & & & \\
\hline & PS25 & Arenito & 4.645 & & 0.1204 & 0.0007 & 0.511900 & 0.000012 & & 1.9 & -14.39 & -8.56 \\
\hline & PS41B & Arenito & 1.013 & & 0.0930 & 0.0005 & 0.511753 & 0.000013 & -0.53 & 1.6 & -17.26 & -9.33 \\
\hline & SA154 & Tufo? & 11.917 & & 0.1092 & & 0.511880 & & -0.44 & 1.7 & & -8.08 \\
\hline & SA156 & Arenito & 4.168 & 22.322 & 0.1129 & 0.0007 & 0.511856 & 0.000009 & -0.43 & 1.8 & -15.25 & -8.84 \\
\hline & SA158A & Arenito & 3.847 & & 0.1202 & & 0.5118 & & & 1.9 & & \\
\hline & SA18 & Arcóseo & 0.706 & 3.770 & 0.1132 & & 0.511903 & & -0.42 & 1.7 & -14.34 & -7.95 \\
\hline \multirow{20}{*}{ 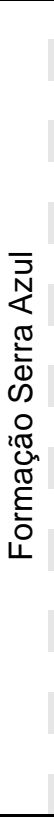 } & & & 13.181 & & & & 0.511 & & & & & \\
\hline & SA06B & Laminito & 16.047 & & 0.1173 & & $0.511 \varepsilon$ & & -0.40 & 1.9 & & -9.34 \\
\hline & & & & & & & & & & & & \\
\hline & SA175 & & 7.3 & & 0.0 & & 0.511 & & & & & -7 \\
\hline & & & & & & & & & & & & \\
\hline & SA07 & & 12.5 & & & & 0.511 & & & & & \\
\hline & SA19B & Laminito & 12.689 & 60. & 0.12 & & 0.511 & & -0.36 & 2.0 & -13.96 & -8.60 \\
\hline & NB98 & & 11.332 & & & & 0.511 & & -0.41 & 1.7 & & -7.50 \\
\hline & SA06C & nito & 18.2 & & & & 0.511 & & & 1.9 & & -8 \\
\hline & SA20D & & 19.7 & 102 & & & 0.511 & & -0 . & 1.8 & & -8.80 \\
\hline & SA19J & & 14.043 & & & & 0.511 & & -0 . & 1. & -12 & -6.48 \\
\hline & SA20C & Laminito & 9.448 & & 17 & & 0.511 & & -0 . & 1.8 & & -8.47 \\
\hline & PS14 & Diamictito & 7.500 & & 0.0976 & & 0.511 & & & & & -6.54 \\
\hline & SA177 & & 1.600 & & 0.05 & & & & & & & -10 \\
\hline & & & 2.6 & & & & 0.51 & & -0.45 & 2. & & \\
\hline & & & & & & & & & & & & \\
\hline & SA179 & Diamictito & 16.027 & & & & 0.511 & & -0.40 & 1. & & -8.51 \\
\hline & SA06A & Diamictito & & & & & 0.511965 & & & 1.6 & & -6.79 \\
\hline & SA20B & Diamictito & 6.988 & 36.194 & 0.1168 & & 0.511946 & & -0.41 & 1.7 & -13.49 & -7.38 \\
\hline & NB129 & Diamictito & 5.637 & 31.072 & 0.1097 & 0.0007 & 0.511853 & 0.000010 & -0.44 & 1.7 & -15.31 & -8.65 \\
\hline \multirow{4}{*}{ 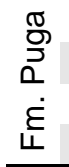 } & PS12 & & & & & & 0.511830 & & & 1.7 & & -8.97 \\
\hline & PS42 & Diamictito & 5.213 & 28.068 & 0.1123 & 0.0007 & 0.511844 & 0.000009 & -0.43 & 1.8 & -15.49 & -9.03 \\
\hline & & & & & & & 0.511926 & 0.000005 & -0.46 & 1.6 & & -6.97 \\
\hline & PS53 & Diamictito & 6.373 & 38.194 & 0.1009 & 0.0006 & 0.511878 & 0.000011 & -0.49 & 1.6 & -14.83 & -7.50 \\
\hline
\end{tabular}

\begin{tabular}{|c|c|c|c|c|c|c|c|c|}
\hline AMOSTRA & Rocha & $\%$ de $\mathrm{K}$ & $\begin{array}{c}\text { Erro de } \\
\text { K (\%) }\end{array}$ & $\begin{array}{c}\mathrm{Ar}^{40} \mathrm{Rad} \\
\mathrm{ccSTP} / \mathrm{g} \\
\left({ }^{\star} 10^{-6}\right)\end{array}$ & $\begin{array}{c}A r^{40} \text { Atm } \\
(\%)\end{array}$ & $\begin{array}{c}\text { Tmax } \\
\text { (Ma) }\end{array}$ & $\begin{array}{l}\text { Idade } \\
\text { (Ma) }\end{array}$ & $\begin{array}{l}\text { Erro } \\
\text { (Ma) }\end{array}$ \\
\hline SA115A & Riolito & 4.0506 & 0.5000 & 141.80 & 2.94 & 745.9 & 731.0 & 14.9 \\
\hline SA115B & Riolito & 3.8503 & 0.5000 & 245.39 & 0.23 & 1186.3 & 1166.9 & 19.3 \\
\hline SA06A1 & Diabásio & 2.1936 & 0.5000 & 119.48 & 1.02 & 1053.6 & 1037.5 & 16.1 \\
\hline
\end{tabular}




\section{DISCUSSÃo}

Os dados apresentados mostram uma maior contribuição de fontes mais jovens nos diamictitos Puga e Serra Azul ( $T_{D M} 1,5$ a 1,6 Ga), apresentando idades mais jovens em direção ao topo (seções 1 e 2, Figura 3). No entanto, a baixa resolução de amostragem na Formação Puga permite apenas sugerir uma tendência de aumento da contribuição de fontes mais jovens para o topo. No que se refere à Formação Serra Azul, na região de Marzagão, esta tendência é nítida, havendo uma mudança brusca de fontes jovens (1,5-1,6 Ga), no topo do diamictito maciço, para fontes mais antigas (1,8-1,9 Ga), na última camada de diamictito laminado (base das seções 2 e 3, Figura 3). Esta última camada glacial é composta de diamictito laminado, com matriz amarela, interpretada como o início da transgressão marinha provocada pelo degelo. Esta predominância de fontes mais antigas perdura até a base da Fm. Raizama, quando o aporte sedimentar de fontes mais jovens parece retornar gradualmente, como observado na redução das idades modelo ( $T_{\mathrm{DM}}$ de 1,9 a 1,60 ) ao longo da sucessão progradacional de depósitos arenosos de maré (topo da seção 2, Figura 3).

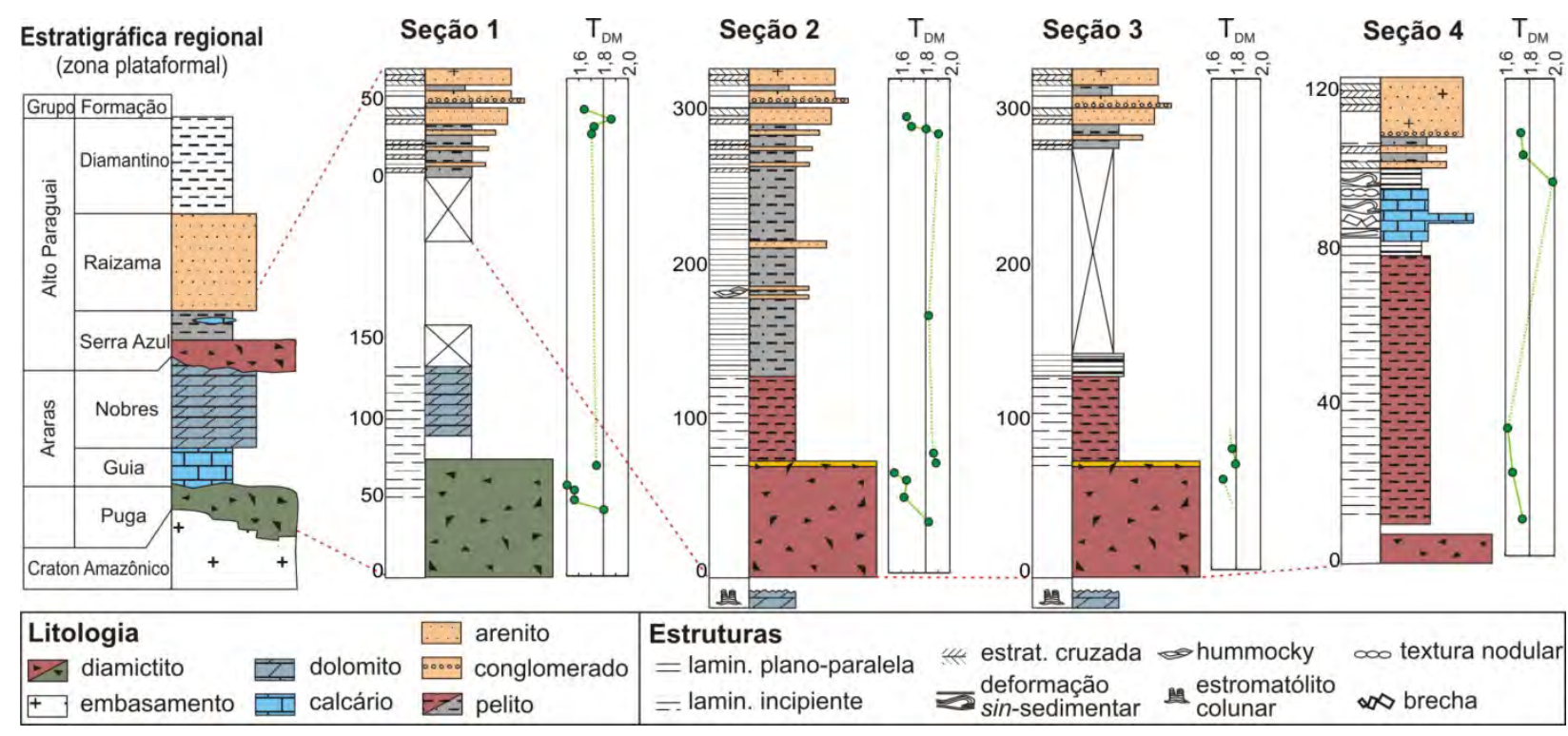

Figura 3. Estratigrafia regional para a Zona Externa da Faixa Paraguai, apresentando correlação com as seções estudadas (linha tracejada vermelha). As idades modelo ( $\left.T_{D M}\right)$ estão representadas ao longo da estratigrafia. A linha pontilhada vermelha marca as correlações estratigráficas.

Na região de Nobres não foi observado o diamictito da Formação Serra Azul, mas os pelitos sobrepostos apresentaram pouca variação em direção à Formação Raizama, exceto pela presença da idade $T_{D M}$ de 2,0 Ga no pelito imediatamente após a 
lente calcária (seção 4, Figura 3), que marca a máxima inundação pós-glacial. Esta idade sugere um aumento na taxa de sedimentação de rochas mais antigas em trato de sistema de mar alto, porém sua ocorrência pontual pode estar relacionada à deposição episódica, que no afloramento apresenta grandes dobras interpretadas como slumps.

A relação de idades mais antigas com ambientes mais profundos pode estar associada à captação de drenagens do interior do paleocontinente proporcionada pela transgressão marinha, onde se encontram as rochas mais antigas. No caso dos diamictitos da Formação Serra Azul, as idades mais jovens, associadas às fases finais da glaciação, podem indicar um enfraquecimento da glaciação, com redução das calotas de gelo no interior do continente. A fase final da glaciação seria marcada pelo início da transgressão marinha e normalização do ciclo hidrológico, porém com icebergs remanescentes. Neste ambiente transicional, seria depositada a última camada de diamictito (amarelo laminado), com características litológicas de transição, mas alimentado pelas rochas-fonte deglaciadas e, nesta fase, erodidas por drenagens.

Dantas et al. (2009) associaram as idades modelo mais jovens ( $T_{\mathrm{DM}}$ 1,5 a 1,6 $\mathrm{Ga}$ ), obtidas nas formações Raizama e Diamantino, à erosão pronunciada de fontes jovens situadas à leste, no Arco Magmático de Goiás e nas faixas Brasília e Araguaia ( $T_{\mathrm{DM}}$ de 0,8 a 1,7 Ga; Pimentel et al., 2001; Moura et al., 2008), como resultado do soerguimento destes domínios e inversão tectônica da bacia precursora da Faixa Paraguai.

\section{Proveniência}

Espacialmente, a Formação Serra Azul apresenta idades mais antigas para a região de Marzagão e mais jovens para a região de Nobres (contrastar as figuras 1 e 3). Esta distribuição pode ser explicada pela compartimentação das províncias geocronológicas do Craton Amazônico. De acordo com a nova divisão proposta por Santos et al. (2000), no centro-nordeste do cráton se encontram as rochas mais antigas, pertencentes às províncias Tapajós-Parima ( $\mathrm{T}_{\mathrm{DM}}$ : 2,0 a 2,2 Ga), Amazônia Central ( $\mathrm{T}_{\mathrm{DM}}: 2,4$ a 2,8 Ga), Carajás ( $\mathrm{T}_{\mathrm{DM}}: 2,5$ a 3,1 Ga) e Transamazonas ( $\mathrm{T}_{\mathrm{DM}}: 2,1$ a 3,1). Do centro para o sudoeste do craton, se encontram as rochas mais jovens, agrupadas nas províncias Rondônia-Juruena ( $\mathrm{T}_{\mathrm{DM}}: 1,7$ a 2,2) e Sunsás ( $\mathrm{T}_{\mathrm{DM}}: 1,2$ a 1,7; Rizzotto, 2001; Matos et al., 2001). 
Os clastos recuperados do diamictito Serra Azul representam diretamente algumas das rochas-fonte que contribuíram para o preenchimento da bacia durante a glaciação. Todos os clastos foram recuperados dos diamictitos da região de Marzagão, cuja matriz apresentou idade $\mathrm{T}_{\mathrm{DM}}$ entre 1,7 e 1,8 Ga (seção 2, Figura 3, Tabela 1). Os clastos sedimentares (quartzitos e arenito) mostraram uma composição isotópica distinta das composições médias obtidas para a matriz do diamictito e demais litologias (Figura 4). O clasto de quartzito mais antigo ( $\mathrm{T}_{\mathrm{DM}}$ 2,2 Ga; Figura 2, Tabela 1) pode ser proveniente das coberturas sedimentares cratônicas, com idades semelhantes encontradas em ambas as províncias Tapajós-Parima e Rondônia-Juruena (Figura 1). $\mathrm{O}$ outro clasto de quartzito $\left(\mathrm{T}_{\mathrm{DM}} 1,9 \mathrm{Ga}\right.$ ) e o clasto de arenito ( $\mathrm{T}_{\mathrm{DM}}$ de 1,8 $\mathrm{Ga}$ ) apresentam idades modelos semelhantes às encontradas na Província RondôniaJuruena e no Grupo Nova Brasilândia (Província Sunsás; Figura 1). A presença de uma fonte com $\mathrm{T}_{\mathrm{DM}}$ tão antigo quanto $2,2 \mathrm{Ga}$, em um diamictito que possui idade $\mathrm{T}_{\mathrm{DM}}$ de 1,7 $\mathrm{Ga}$, requer a contribuição de outra rocha-fonte bem mais jovem. A única região cratônica com rochas apresentando idades modelo tão jovens se encontra a noroeste, na Província Sunsás (e.g. Basalto Rio Branco de $T_{D M}$ 1,25 Ga, Rizzotto, 2001; e Granito Santa Helena de $\mathrm{T}_{\mathrm{DM}}$ 1,36 a 1,62 Ga, Geraldes et al., 2001).

As idades K-Ar (Tabela 2), obtidas nos clastos vulcânicos da mesma região, apresentaram idades bastante jovens e não muito comuns no Cráton Amazônico, com possíveis rochas-fonte restritas à Província Sunsás (Figura 1). Não se encontrou na literatura uma rocha-fonte correspondente do clasto de riolito porfirítico mais antigo (1167 $\pm 19 \mathrm{Ma})$, sendo o único evento mais próximo desta idade representado pelo magmatismo máfico Nova Floresta, com idades Ar-Ar de $1198 \pm 3$ a $1203 \pm 4 \mathrm{Ma}$ (gabros; Thover et al., 2002). Basaltos e gabros do mesmo evento magmático, encontrados em um graben, possuem idades K-Ar de $982 \pm 10$ e $1038 \pm 14$ Ma (Tohver et al., 2001), sendo esta última idade coerente com o clasto de diabásio da Formação Serra Azul (1037 $\pm 16 \mathrm{Ma})$.

O clasto de riolito porfirítico mais jovem apresentou uma idade incomum (731 \pm $15 \mathrm{Ma}$, Tabela 2) na literatura sobre o Craton Amazônico. Um único registro de idades criogenianas no cráton foi reportado por Pinho \& Van Schmus, (2001) e referem-se a idades U-Pb obtidas pela técnica de ID-TIMS em zircões separados de um andesito piroclástico e do tonalito da Faixa Cabaçal. Os autores mencionam que idades variando em 645 e 2630 Ma foram obtidas em zircões recuperados do tonalito Cabaçal e que os 
mais jovens provavelmente representem xenocristais assimilados de rochas sedimentares pelo magma. Os zircões deste tonalito são geralmente discordantes e uma idade $\mathrm{Pb}-\mathrm{Pb}$ de $710 \mathrm{Ma}$ foi determinada em um dos zircões mais concordantes. No andesito foram obtidas idades U-Pb variando entre 600 e $2100 \mathrm{Ma}$. Embora a interpretação destas idades seja complexa, há evidência de eventos magmáticos no cráton durante o criogeniano (Pinho \& Van Schmus, 2001). Além disso, a idade de 730 Ma coincide com a quebra do Supercontinente Rodínia e pode estar associada ao magmatismo da fase rift da bacia precursora da Faixa Paraguai ou da Faixa Araguaia (Figura 1), ainda não encontrados.

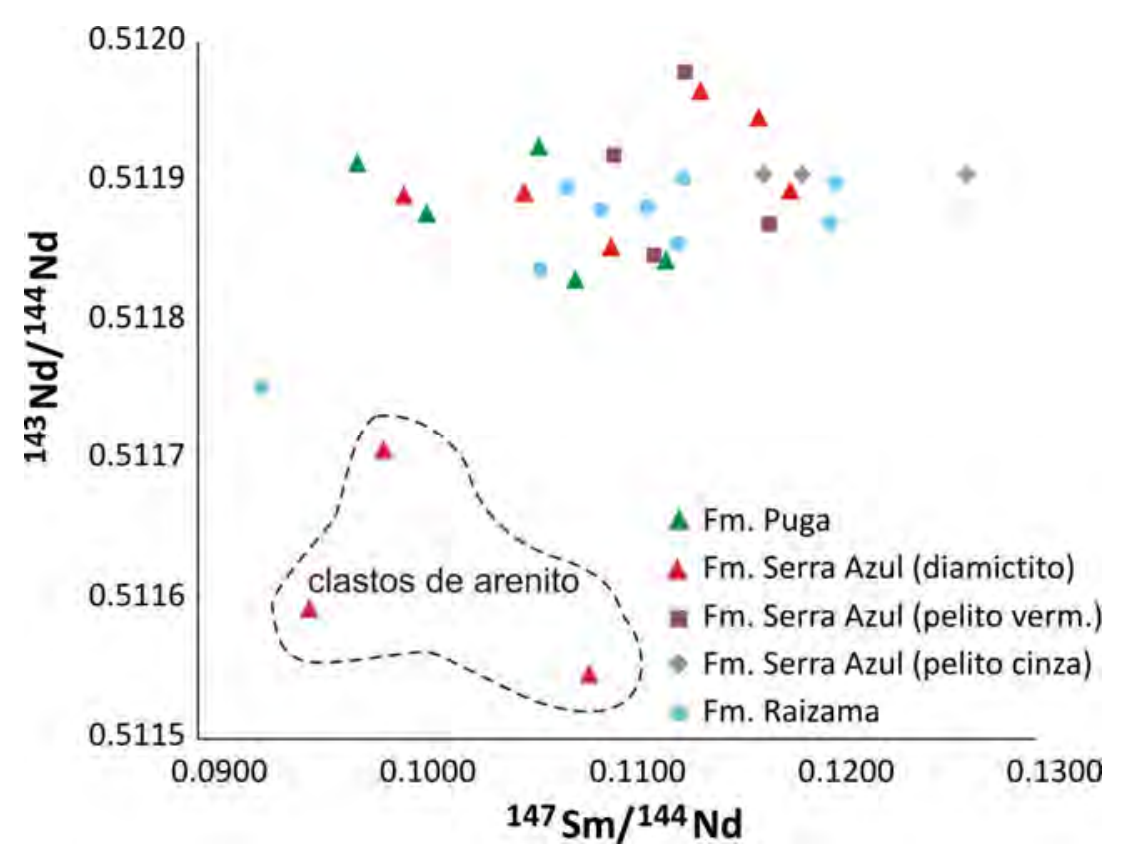

Figura 4. Gráfico ${ }^{143} \mathrm{Nd} /{ }^{144} \mathrm{Nd}$ versus ${ }^{147} \mathrm{Sm} /{ }^{144} \mathrm{Nd}$, mostrando composição isotópica de clastos, representantes de 3 rochas-fonte, e distintos das razões isotópicas médias obtidas na matriz.

\section{CONCLUSÕES}

As idades K-Ar obtidas em clastos vulcânicos recuperados de diamictitos forneceram uma idade máxima de deposição para a Formação Serra Azul de 731 Ma e indicaram a proveniência de outras duas fontes com idades de 1,17 e 1,04 Ga. Estas idades são características da Província Geocronológica Sunsás, situada a leste da área de estudo. As idades modelo obtidas na matriz dos diamictitos, dos dois eventos glaciais (Puga e Serra Azul), evidenciaram uma tendência de idades mais jovens para o topo, com uma brusca mudança para fontes mais antigas no último estrato. Esta semelhança, entre as idades $T_{D M}$ e na contribuição de rochas-fonte das duas unidades, 
sugere que a dinâmica das geleiras (comportamento erosivo) foi bastante parecida nas duas glaciações. As possíveis rochas-fonte se encontram no Cráton Amazônico, estando as mais antigas a norte da área de estudo, nas respectivas províncias geocronológicas Rondônia-Juruena e Tapajós-Parima, enquanto que as rochas-fonte mais jovens se encontram a oeste-noroeste da área de estudo, na Província Geocronológica Sunsás.

Nas rochas depositadas em ambiente profundo após o término da Glaciação Serra Azul, predominam as fontes mais antigas na região entre Marzagão e Planalto da Serra e fontes mais jovens na região de Nobres. Esta distribuição espacial mostra 0 predomínio na contribuição de rochas-fonte proximais, cuja deposição nas regiões de Marzagão e Planalto da Serra recebeu sedimentos provenientes das províncias geocronológicas Rondônia-Juruena e Tapajós-Parima, enquanto que a deposição na região de Nobres recebeu contribuições da Província Geocronológica Sunsás (Figura 1).

As rochas da base da Formação Raizama mostraram uma tendência de idades modelo mais jovens associadas ao raseamento da bacia e instalação de uma planície de maré. Existem duas possibilidades para estas idades mais jovens, envolvendo o transporte de sedimentos por drenagens com nascentes instaladas nas: a) serras situadas a oeste, na Província Geocronológica Sunsás; ou b) cadeias de montanhas recentemente soerguidas a leste, no Arco Magmático de Goiás e na Faixa Araguaia, marcando uma inversão da bacia.

\section{REFERÊNCIAS}

Almeida, F.F.M. 1964. Geologia do Centro-Oeste Matogrossense. Ministério de Minas e Energia, Departamento Nacional de Produção Mineral, Boletim da Divisão de Geologia Mineral, 215: 1-137.

Alvarenga, C.J.S., Trompette, R. 1992. Glacial influenced turbidite sedimentation in the uppermost Proterozoic and Lower Cambrian of the Paraguay Belt (Mato Grosso, Brazil). Palaeogeography, Palaeoclimatology, Palaeoecology, 92: 85-105.

Dantas, E.L., Alvarenga, C.J.S., Santos, R.V., Pimentel, M.M. 2009. Using Nd isotopes to understand the provenance of sedimentary rocks from a continental margin to 
a foreland basin in the Neoproterozoic Paraguay Belt, Central Brazil. Precambrian Research, 170:1-12.

De Paolo, D., 1981. Neodymium isotopes in the Colorado Front Range and crust-mantle evolution in the Proterozoic. Nature, 291: 193-196.

Elderfield, H., Greaves, M.J. 1982. The rare earth elements in seawater. Nature, 296: 214-219.

Figueiredo, M.F., Babinski, M., Alvarenga, C.J.S., Pinho, F.E.C. 2008. Nova unidade litoestratigráfica registra glaciação ediacarana: Formação Serra Azul. Revista Geologia-USP, 8: 65-75.

Geraldes, M.C., Van Schmus, W.R., Condie, K.C., Bell, S., Teixeira, W., Babinski, M. 2001. Proterozoic geologic evolution of the SW part of the Amazonian craton in Mato Grosso state, Brazil. Precambrian Research, 111: 91-128

Hennies, W.T., 1966. Geologia do Centro-Norte Mato-Grossense. Tese de Doutoramento, Escola Politécnica, Universidade de São Paulo, 65 p.

Matos, J. B., Schorscher, J.H.D., Geraldes, M.C., Souza, M.Z.A. 2001. The Rio Alegre volcanosedimentar sequence (SW Amazonian Craton, Brazil): Chemical and isotopes (U/Pb and Sm/Nd) constraints and tectonic implications. In: Workshop "Geology of the SW Amazonian Craton: State-of-the-art", Extended Abstract, p. 56-59.

Nogueira, A.C.R., Riccomini, C., Sial, A.N., Moura, C.A.V., Fairchild, T.R. 2003. Softsediment deformation at the base of the Neoproterozoic Puga cap carbonate (sowthwestern Amazon craton, Brazil) confirmation of rapid icehouse to greenhouse transition in Snowball Earth. Geology, 31: 613-616.

Nogueira A.C.R., Riccomini C. 2006. O Grupo Araras (Neoproterozóico) na parte norte da Faixa Paraguai e sul do Cráton Amazônico, Brasil. Revista Brasileira de Geociências, 36: 623- 640.

Pinho, F.E.C., Van Schmus, W.R. 2001. Cabaçal Belt: more complications about the evolution of the southern Amazon Craton. In: Workshop "Geology of the SW Amazonian Craton: State-of-the-art", Extended Abstract, p. 75-78. 
Rizzotto, G.J. 2001. Reavaliação do Ciclo Orogênico Sunsás/Aguapeí no sudoeste do Cráton Amazônico. In: Workshop "Geology of the SW Amazonian Craton: Stateof-the-art", Extended Abstract, p. 66-70.

Santos, J.O.S., Hartmann, L.A., Gaudette, H.E., Groves, D.I., McNaughton, N.J., Fletcher, I.R. 2000. A new understanding of the provinces of the Amazon Craton based on integration of field mapping and $\mathrm{U}-\mathrm{Pb}$ and $\mathrm{Sm}-\mathrm{Nd}$ geochronology. Gondwana Research, 3: 453:488.

Tohver, E., Van der Pluijm, B., Van der Voo, R., Rizzotto, G.I., Scandolara, J.E. 2002. Paleogeography of the Amazon craton at $1.2 \mathrm{Ga}$ : early Grenvillian collision with te Llano segment of Laurentia. Earth and Planetary Science Letters, 199:185200.

Tohver, E., Van der Pluijm, B., Scandolara, J.E., Rizzotto, G. 2001. A reassessment of the tectonics and Paleogeography of the Grenville-aged Sunsás-Aguapeí Belt, SW Amazon Craton: new paleomagnetic and ${ }^{40} \mathrm{Ar} /{ }^{39} \mathrm{Ar}$ data. In: Workshop "Geology of the SW Amazonian Craton: State-of-the-art", Extended Abstract, p. 151-154. 


\section{CAPÍTULO 6 DISCUSSÃO E CONCLUSÕES}

As discussões referentes a cada conjunto específico de dados foram realizadas ao longo da tese, como pode ser conferido nos itens de interpretação ambiental do Capítulo 3 e nos itens "discussão" de cada um dos cinco artigos que compõem o corpo desta tese. Neste capítulo, serão integradas todas as interpretações previamente discutidas, de forma a propiciar uma visão global sobre a história geológica das rochas estudadas da Faixa Paraguai.

\subsection{DISCUSSÃO}

A discussão será desenvolvida em ordem geocronológica dos eventos registrados na Faixa Paraguai, sempre considerando os resultados obtidos neste trabalho e a sua importância no contexto global.

\subsubsection{A Glaciação Marinoana na Faixa Paraguai}

A transição entre o Criogeniano e o Ediacarano é marcada pelo fim da Glaciação Marinoana e o início da deposição de sua capa carbonática, que apresenta anomalias negativas de $\delta^{13} \mathrm{C}$ (ca. - 5\%) e estruturas típicas, como tubestones associados a estromatólitos estratiformes em dolomito róseo, pseudomorfos de cristais de aragonita e mega ripples, nos dolomitos escuros e rítmicos. No estado do Mato Grosso, uma capa carbonática característica de $30 \mathrm{~m}$ foi reconhecida na cidade de Mirassol d'Oeste (domínio tectônico de cobertura de antepaís; Nogueira et al., 2003), recobrindo a Formação Puga. Assim, o limite entre o Criogeniano e o Ediacarano na Faixa Paraguai é evidenciado pela superfície de contato entre os diamictitos da Formação Puga e os carbonatos com anomalia negativa de $\delta^{13} \mathrm{C}$ que os sobrepõem (Formação Mirassol d'Oeste e Formação Guia).

A Glaciação Marinoana foi inicialmente considerada de abrangência global, cobrindo todo o planeta (Snowball Earth, Hoffman et al., 1998). Esta idéia foi contraposta por outras hipóteses menos catastróficas, assumindo uma glaciação global 
com cerca de $40 \%$ da superfície descoberta ao longo do Equador (Slushball Earth, Hyde et al., 2000) ou diversas glaciações de altitude geradas pelo soerguimento pré-rift que fragmentou o Supercontinente Rodínia (Zipper-Rift, Eyles \& Januszczak, 2004).

Os dados sedimentológicos obtidos para a Formação Puga, em ambientes mais profundos, mostraram uma variação de fácies freqüente, indicadoras da alternância de ambientes mais profundos e mais rasos. As interpretações das fácies sugerem um ciclo hidrológico atuante durante esta glaciação, com recuos, associados à liberação de icebergs, e avanços das geleiras. Mais ainda, a mudança na contribuição das fontes mais antigas, situadas a norte, para fontes mais jovens, situadas a leste, identificada ao longo da Formação Puga, sugere mudanças na dinâmica das geleiras. Esta configuração contraria a proposta da Snowball Earth, de um planeta completamente coberto por gelo durante toda a glaciação.

A geometria tabular dos depósitos glaciais sugere fluxos não confinados para a deposição da Formação Puga na região de Planalto da Serra, enquanto que a análise da geometria das camadas da região de Nobres não foi possível, devido à limitação da descrição em furos de sondagem. Além disso, a presença de clastos caídos em ritmitos de mar profundo foi interpretada como transportados por icebergs, o que exige a presença de geleiras chegando ao nível do mar. Estas interpretações se opõem à idéia de uma glaciação de altitude, com fluxos confinados e restrição de icebergs em mar aberto, como a proposta Zipper-Rift. Se a hipótese Slushball for assumida para a região, seria necessário o posicionamento da bacia precursora da Faixa Paraguai no limiar entre a área coberta de gelo (60\%) e a área equatorial descoberta (40\%), ou seja, no limite da zona tropical (paralelo $30^{\circ}$ ). Corroborando esta possível paleogeografia da margem sul-sudeste do Cráton Amazônico, Trindade \& Macouin (2007) sugerem o posicionamento da bacia precursora da Faixa Paraguai exatamente no paralelo $30^{\circ} \mathrm{em} 620 \mathrm{Ma}$, com base nos dados paleomagnéticos da capa carbonática de Mirassol d'Oeste. Apesar do primeiro modelo Slushball ter sido criticado ( Hoffman \& Schrag, 2001) por não suportar a longa duração da glaciação Marinoana (4 my), modelos posteriores tem a reafirmado (Peltier et al., 2007), permanecendo o debate (Kaufman, 2007). 


\subsubsection{A deglaciação Marinoana na Faixa Paraguai}

Neste trabalho, a capas carbonáticas strictu sensu não foram reconhecidas na plataforma mais profunda (domínio tectônico externo). Mas, foram encontrados $5 \mathrm{~m}$ de dolomito róseo, laminado e rítmico, contendo slumps e estromatólitos colunares e dômicos no topo, depositados diretamente sobre da Formação Puga. No ambiente de margem de bacia, sobre a Formação Puga, foram depositados $4 \mathrm{~m}$ de dolomito sem semelhanças com a capa carbonática strictu sensu. Este dolomito apresenta cor escura, é rico em matéria orgânica e possui as unidades $A, B, C$ e $E$ da seqüência de

Bouma. Ambos os dolomitos apresentaram anomalias negativas de $\delta^{13} \mathrm{C}(\sim 6 \%) \mathrm{e}$ foram interpretados como cronocorrelatos da capa carbonática, servindo como nível estratigráfico ao longo da bacia, que marca o início do Ediacarano em sucessões com a capa carbonática strictu sensu ausente.

Além disso, os dados isotópicos de $\delta^{13} \mathrm{C}$ se mostram homogêneos ao longo da bacia, quando comparado este trabalho com os dados disponíveis na literatura para a região (Nogueira et al., 2003, 2007; Alvarenga et al., 2004, 2008, 2010; Font et al., 2006; Riccomini et al., 2007). Isto sugere um período de rápida homogeneização oceânica, inferior ao tempo de residência do carbono. O mesmo comportamento homogêneo pode ser observado nas capas carbonáticas ao longo da plataforma Yangtze, base da Formação Doushantuo (Zhu et al., 2007; Jiang et al., 2007; McFadden et al., 2008) e na base da Formação Maieberg (Namíbia, Hurtgen et al., 2006). As causas desta anomalia negativa de $\delta^{13} \mathrm{C}$ ainda são controversas.

Contrapondo a idéia de um ambiente homogêneo durante a deposição das capas carbonáticas marinoanas, Grotzinger \& Knoll (1995) sugeriram a ação de upwellings trazendo carbono isotopicamente leve do ambiente profundo para a plataforma, mecanismo este que exige um ambiente estratificado. Ao contrário de outros autores, nos primeiros metros da capa carbonática da Formação Doushantuo, Shen et al. (2005) identificaram um gradiente entre - 2,5\%o (plataforma) e - 9\%o (margem de bacia), que atribuiu à estratificação do oceano pós-glacial, assumindo que e os valores negativos estejam relacionados à oxidação anaeróbica intensa de metano, devido à carência de sulfato dissolvido na água do mar.

Nos dolomitos de capa da Faixa Paraguai não é observado este forte gradiente ao longo da bacia. Ao contrário, os valores variam cerca de $2 \%$, dentro do gradiente 
encontrado nos oceanos atuais (Kroopnik, 1980; Broecker \& Peng, 1982). Mesmo considerando esta variação pequena, os carbonatos de capa da Faixa Paraguai mostram uma relação inversa do encontrado por Shen et al. (2005) para a Formação Doushantuo. Ou seja, os valores levemente mais negativos se encontram na plataforma (até - 7\%; Font et al., 2006), no nível das mega ripples, enquanto que na margem de plataforma apresentam valores menos negativos $(-5 \%)$ e na margem de bacia novamente mais negativos $(-7 \%)$.

Hoffman et al. (1998) atribuíram os valores negativos anômalos de $\delta^{13} \mathrm{C}$ à inibição dos organismos fotossintetizantes durante a snowball Earth, sugerindo um rápido aumento da alcalinidade dos oceanos com o fim da glaciação, resultando na rápida deposição das capas carbonáticas. Porém, dados paleomagnéticos obtidos por Trindade et al. (2003) revelaram várias inversões ao longo dos dolomitos de capa de Mirassol d'Oeste, atestando para uma deposição lenta e prolongada destas capas carbonáticas.

Outra explicação para as anomalias negativas de $\delta^{13} \mathrm{C}$ é a oxidação da matéria orgânica dissolvida na água do mar (Rothman et al., 2003), o que sugere um mar não estratificado e com oxigenação de águas profundas. No entanto, os resultados isotópicos de enxofre apresentados neste trabalho, de elementos traços indicadores de paleoredox de Font et al. (2006) e os biomarcadores identificados por Elie et al. (2007) sugerem a instalação de ambientes anóxicos, colonizados por bactérias redutoras de sulfato, ao longo de toda a bacia, logo após a glaciação Puga.

\subsubsection{O Grupo Araras e a evolução biogeoquímica dos oceanos ediacaranos}

Vários autores têm identificado evidências biogeoquímicas do desenvolvimento de oceanos estratificados após a deposição das capas carbonáticas. Dados de geoquímica elementar de ferro e manganês e isotópicos de carbono e enxofre, obtidos na Namíbia (Hurtgen et al., 2006), sugerem uma estratificação na primeira metade da Formação Maieberg, imediatamente após a deposição das capas carbonáticas. $\mathrm{Na}$ Formação Doushantuo, China, vários trabalhos tem sido realizados e um grande volume de dados foi produzido, e serão discutidos abaixo.

O detalhamento da Formação Doushantuo permitiu a observação de variações espaciais de grande amplitude nos valores de $\delta^{13} \mathrm{C}$ em carbonatos ao longo da 
plataforma que, quando comparados com os valores de $\delta^{13} \mathrm{C}$ da matéria orgânica, sugerem um mar estratificado (Ader et al., 2009). Um modelo proposto para explicá-las assume uma camada superficial oxigenada sobre outra anóxica, ocorrendo uma terceira camada metanogênica, mais profunda, em ambientes restritos da plataforma interna (Ader et al., 2009). Outro modelo proposto para a Formação Doushantuo, com base em dados isotópicos de enxofre e abundância de ferro em espécies minerais reativas, pirita e óxidos, sugere uma estratificação semelhante à anterior, com uma camada superficial oxigenada sobre outra anóxica. A diferença deste modelo está em assumir a presença de uma cunha sulfídica sustentada pela atividade bacteriana, restrita à plataforma, dentro da coluna anóxica ferruginosa (Li et al., 2010).

Ao contrário do observado na Namíbia e na China, os carbonatos do Grupo Araras não apresentaram variação isotópica espacial de $\delta^{13} \mathrm{C}$ acima de $3 \%$ ao longo da plataforma, exceto para ambientes restritos $\left(\delta^{13} \mathrm{C}\right.$ até $+9 \%$; Alvarenga et al., 2004). Além disso, valores anomalamente pesados de $\delta^{34} S$ determinados no sulfato presente nos carbonatos e em piritas, ao longo de toda a sucessão estudada, sugerem uma anoxia difundida, abrangendo os ambientes de talude e de maré. O alto fracionamento isotópico do enxofre encontrado está dissociado da relação positiva entre piritas pesadas e baixa produtividade de bactérias redutoras de sulfato, como ocorre na cunha euxínica sugerida por Li et al. (2010). Porém, considerando-se a tendência mais leve das piritas do Grupo Araras depositadas no talude, e não levando em conta os valores absolutos, o modelo de Li et al. (2010) poderia ser adequado ao Grupo Araras pela ampliação da cunha euxínica até o talude. Por outro lado, os valores de $\delta^{13} \mathrm{C}$ anomalamente positivos (até + 9\%o), encontrados por Alvarenga et al. (2004), podem ser explicados pelo modelo de restrição da plataforma, com a existência de uma camada inferior metanogênica (Ader et al., 2009).

De qualquer forma, a camada superior oxigenada, prevista em todos os modelos, pressupõe uma maior bioatividade de organismos fotossintetizantes e a redução das bactérias redutoras de sulfato. O esperado é que a Formação Nobres (ambiente de maré) tenha registrado essa camada superior da coluna d'água, que pode ser identificada por valores de $\delta^{13} \mathrm{C}$ próximos de $0 \%$ e de $\delta^{34} \mathrm{~S}$ no sulfato mais pesados, assim como um maior fracionamento de carbono e menor de enxofre. Quase todas estas respostas isotópicas foram observadas na Formação Nobres, exceto a redução 
no fracionamento de enxofre. Isso mostra que a camada superior da coluna d'água era capaz de manter a atividade de bactérias redutoras de sulfato.

Em períodos de exposição da bacia, na Formação Nobres, observa-se uma redução considerável no fracionamento isotópico do enxofre e drástica no fracionamento isotópico de carbono, possivelmente como resposta à mortandade preferencial dos organismos fotossintetizantes e subsistência das bactérias redutoras de sulfato no substrato.

\subsubsection{Uma nova glaciação na Faixa Paraguai}

Glaciações ediacaranas têm sido identificadas em diversos locais, como em Newfoundland (Eyles \& Eyles, 1989), Noruega (Bingen et al., 2005; Halverson et al., 2005), Avalônia (Thompson \& Bowring, 2000), Escócia e Irlanda (Condon \& Prave, 2000; Dempster et al., 2002), norte da China (Xiao et al., 2004) e Brasil (este trabalho). Porém, apenas a Formação Gaskiers possui uma idade absoluta bem estabelecida entre 582 a 580 Ma (Bowring et al., 2003), sendo a correlação desta com as demais ainda imprecisa.

Este evento glacial ediacarano, denominado Gaskiers, parece ter sido de menor duração e ocorrido em uma área mais restrita. Provavelmente, esta glaciação seja polar e não esteja relacionada ao contexto de glaciações globais, como a Marinoana. Porém, a carência de dados paleomagnéticos e geocronológicos nas diversas sucessões correlatas ainda não permite uma reconstrução paleogeográfica consensual e a determinação de sua extensão. De qualquer maneira, este evento glacial vem ganhando importância por preceder o aparecimento dos primeiros organismos macroscópicos, há 575 Ma (Narbonne, 2005), que evoluem durante o restante do Ediacarano, até a explosão de vida cambriana.

Neste trabalho, a correlação da Formação Serra Azul com a Formação Gaskiers (582 Ma) foi reforçada por sua semelhança sedimentológica, quimioestratigráfica e geocronológica. Em termos sedimentológicos, a Formação Serra Azul possui uma sucessão muito semelhante à sucessão encontrada na Formação Gaskiers (Myrow \& Kaufman, 1999), apresentando, da base para o topo, diamictitos glacio-marinhos vermelhos maciços, seguido por pelito vermelho transgressivo e uma fina camada de calcário de máxima inundação, recoberto por pelito cinza esverdeado. Os dados de 
proveniência sugerem que o comportamento das geleiras foi semelhante ao observado na Formação Puga. Esta semelhança, na evolução da contribuição de fontes, pode estar relacionada à manutenção do mesmo paleorelevo (controlador da dinâmica das geleiras) entre a glaciação Puga e a glaciação Serra Azul.

Os dados de $\delta^{13} \mathrm{C}$ nos carbonatos da Formação Serra Azul se mostraram semelhantes aos da Formação Gaskiers, com anomalias negativas de cerca de - 6\%. Porém, a não existência de razões isotópicas de $\mathrm{Sr}$ na Formação Gaskiers impossibilitou o uso desta ferramenta na correlação mais refinada desta com a Formação Serra Azul. Apesar disso, uma idade Pb-Pb de $596 \pm 26 \mathrm{Ma}$, obtida nos carbonatos da Formação Serra Azul, pouco acima da anomalia negativa de $\delta^{13} C$, aumenta a possibilidade de correlação desta formação com a glaciação Gaskiers.

Adicionalmente, a intercalação de areia para o topo da Formação Serra Azul, gradando para uma unidade espessa e expressivamente arenosa (Formação Raizama), é bastante semelhante à evolução de topo da Formação Gaskiers, que grada para a Formação Drook (Narbonne \& Gehling, 2003). É nesta última formação que são encontrados exemplares métricos mais antigos da Fauna de Ediacara, $1000 \mathrm{~m}$ acima dos diamictitos (Narbonne \& Gehling, 2003). A semelhança entre as duas sucessões coloca o topo da Formação Serra Azul e a base da Formação Raizama como um intervalo candidato a possuir o mesmo registro paleobiológico, principalmente pela possível proximidade dos paleocontinentes Amazônico e Laurentia (Trindade et al., 2007).

As anomalias negativas de $\delta^{13} \mathrm{C}$ associadas a este evento glacial ainda são pouco discutidas na literatura, devido à escassez de afloramentos carbonáticos, encontrados apenas nas formações Gaskiers e Serra Azul. Da mesma forma, a correlação desta anomalia negativa com as outras duas anomalias, encontradas nas sucessões carbonáticas da segunda metade do Ediacarano (EN2-Doushantuo, McFadden et al., 2008; Wonoka-Shuram, Burns \& Matter,1993; Calver, 2000), é controversa, pois as razões isotópicas de $\mathrm{Sr}$ dessas sucessões são similares e não discriminantes. Diante da escassez de registro glacial, McFadden et al. (2008) interpretam a anomalia EN2-Doushantuo (anterior ao evento Wonoka-Shuram) como o resultado de uma evento de oxigenação das águas profundas do mar ediacarano, considerando-a mais antiga que $580 \mathrm{Ma}$. Isto implicaria em um registro local para as anomalias negativas de $\delta^{13} \mathrm{C}$ associadas às glaciações Gaskiers e Serra Azul, ou a um 
hiato na sedimentação da Formação Doushantuo, ou ainda à possível correlação do início da anomalia Wonoka-Shuram com as referidas glaciações.

A existência de anomalias não associadas aos eventos glaciais tem sugerido sua dissociação, admitindo mecanismos que tenham interferido na biogeoquímica dos oceanos e no clima, provocando as glaciações neoproterozoicas (Halverson, 2006). Adicionalmente, o reconhecimento de um impacto meteorítico de grandes proporções (Acraman, Austrália; Gostin et al., 1986), com provável idade de 580 Ma (Grey et al., 2003), adiciona ao cenário uma nova hipótese para as mudanças climáticas, alteração na biogeoquímica dos oceanos e gatilho para a evolução macroscópica ediacarana (Calver \& Lindsay, 1998; Williams \& Wallace, 2003; Grey et al., 2003).

\subsection{CONCLUSÕES}

A Formação Puga apresentou evidências de uma glaciação com ciclo hidrológico ativo, com registros de recuos e avanços da geleira, bem como uma variação de fontes mais antigas (na base), situadas a norte, para fontes mais jovens (no topo), situadas a leste. O único modelo proposto na literatura que se aproxima das feições observadas é o de uma Slushball Earth.

Carbonatos equivalentes mais profundos dos dolomitos de capa, da Formação Mirassol d'Oeste, foram encontrados ao longo de toda a bacia precursora da Faixa Paraguai. Suas composições evidenciaram um tempo de homogeneização da água do mar menor ou igual ao tempo de residência do carbono, assim como uma redução geral da bioatividade no ambiente profundo (organismos fotossintetizantes e redutores).

Os carbonatos inter-glaciais do Grupo Araras mostraram um pequeno gradiente isotópico de carbono ao longo da bacia, semelhante aos atuais, interpretados como resultado da distribuição preferencial de organismos fotossintetizadores em ambientes rasos. Os isótopos de carbono orgânico e enxofre evidenciam uma anoxia generalizada nos oceanos, havendo o rápido restabelecimento de organismos fotossintetizantes e lento para as bactérias redutoras de sulfato, logo após as capas carbonáticas. $\mathrm{Na}$ seqüência, a bioprodução das bactérias redutoras de sulfato parece superar a dos organismos fotossintetizantes, sugerindo uma explosão bacteriana nos oceanos. Em períodos de exposição da bacia, as assinaturas isotópicas de carbono e enxofre 
mostram uma drástica redução na bioatividade (organismos fotossintetizantes e redutores).

A Formação Serra Azul registra uma glaciação ediacarana na Faixa Paraguai, com uma idade isocrônica $\mathrm{Pb}-\mathrm{Pb}$ de $596 \pm 26$ Ma obtida em carbonatos, que aumenta a possibilidade de correlação com a Formação Gaskiers (582 Ma). O registro sedimentológico e de isótopos estáveis de ambas as formações é bastante semelhante, porém apenas a Formação Serra Azul possui razões isotópicas de Sr, que se apresentaram coerentes com a segunda metade do Ediacarano. A proveniência dos sedimentos da Formação Serra Azul indica que o comportamento das suas geleiras foi semelhante àquelas da Formação Puga, interpretado como resultado da manutenção de um paleorelevo semelhante entre elas. Os clastos dos diamictitos mostraram a contribuição de uma fonte jovem (730 Ma) e de localização ainda incerta (Cráton Amazônico, Arco Magmático de Goiás ou relicto da fase rift da bacia precursora). 



\section{REFERÊNCIAS BIBLIOGRÁFICAS}

Ader, M., Macouin, M., Trindade, R.I.F., Hadrien, M-H., Yang, Z., Sun, Z., Besse, J. 2009. A multilayered water column in the Ediacaran Yangtze platform? Insights from carbonate and organic matter paired $\delta^{13} \mathrm{C}$. Earth and Planetary Science Letters, 288: 213-227.

Almeida, F.F.M. 1945. Geologia do sudoeste mato-grossense. Departamento Nacional de Produção Mineral, Boletim da Divisão de Geologia e Mineralogia, 116: 1-118.

Almeida, F.F.M. 1964. Geologia do Centro-Oeste Matogrossense. Ministério de Minas e Energia, Departamento Nacional de Produção Mineral, Boletim da Divisão de Geologia Mineral, 215: 1-137.

Almeida, F.F.M. 1965. Geossinclíneo Paraguaio. $1^{\text {a }}$ Semana de Debates Geológicos, Porto Alegre, Centro Acadêmico de Estudos Geológicos. Anais, p. 88-109.

Almeida, F.F.M. 1967. Nota sobre o Pré-Cambriano a região central de Goiás. Boletim Paranaense de Geociências, 26: 19-22.

Almeida, F.F.M. 1969. Diferenciação tectônica da plataforma brasileira. $23^{\circ}$ Congresso Brasileiro de Geologia, Salvador, Sociedade Brasileira de Geociências, Anais 4:3-6.

Almeida, F.F.M. 1974. Antefossa do Alto Paraguai. $28^{\circ}$ Congresso Brasileiro de Geologia, Porto Alegre, Sociedade Brasileira de Geociências 4:3-6.

Almeida, F.F.M. 1984. Procíncia Tocantins, setor sudoeste. In: Almeida, F.F.M., Hasui, Y. (Eds.). O Pré-Cambriano do Brasil. Ed. Blücher, São Paulo, p. 265-281.

Almeida, F.F.M., Mantovani, M.S.M. 1975.Geologia e geocronologia do Granito de São Vicente, Mato Grosso. Anais da Academia Brasileira de Ciências 47:451-458.

Alsharhan, A.S., Kendall, C.G.St.C. 2003. Holocene coastal carbonates and evaporites of the southern Arabian Gulf and their ancient analogues. Earth Science Reviews, 61:191-243.

Alvarenga, C.J.S. 1988. Turbiditos e a glaciação do final do Proterozóico Superior no Cinturão Paraguai, Mato Grosso. Revista Brasileira de Geociências, 18: 323-327.

Alvarenga, C.J.S. 1990. Phénomenes Sédúnentaires, Structuraux et Circulation de Fluides Développés à la Transition Chane-Craton: Example de la Quote Paraguai d'age Proterozoque Supérieur, Mato Grosso, Brésil. These Docteur, Université d'Aix Marseille HI, France, $177 \mathrm{p}$.

Alvarenga, C.J.S., 1988. Turbiditos e a glaciação do final do Proterozóico Superior no Cinturão Paraguai, Mato Grosso. Revista Brasileira de Geociências, 18: 323-327.

Alvarenga, C.J.S., Dardenne, M.A., Santos, R.V., Brod, E.R., Gioia, S.M.C.L., Sial, A.N., Dantas E.L., Ferreira, V.P. 2008. Isotope stratigraphy of Neoproterozoic cap carbonates in the Araras Group, Brazil. Gondwana Research, 13: 469-479.

Alvarenga, C.J.S., Moura, C.A.V., Gorayeb, P.S.S., Abreu, F.A.M. 2000. Paraguay and Araguaia Belts. In: Cordani, U.G., Milani, E.J., Thomaz Filho, A., Campos, D.A. 
(Eds.) Tectonic Evolution of South America. ABC/DNPM/MCT/CNPq/FINEP/ANP, Rio de Janeiro, p. 183-193.

Alvarenga, C.J.S., Saes, G. 1992. Estratigrafia e sedimentologia do Proterozóico Médio e Superior da região sudeste do Cráton Amazônico. Revista Brasileira de Geociências, 22: 493-499.

Alvarenga, C.J.S., Santos, R.V., Dantas, E.L. 2004. C-O-Sr isotopic stratigraphy of cap carbonates overlying Marinoan-age glacial diamictites in the Paraguay Belt, Brazil. Precambrian Research, 131: 1-21.

Alvarenga, C.J.S., Santos, R.V., Dantas, E.L., Brod, E.R., Gióia, S.M.C.L. 2003. C, O and $\mathrm{Sr}$ isotope in the cap carbonate sequence overlying Sturtian-Rapitan and Varanger-Marinoan Glacial events in Brazil. IV South American Symposium on Isotope Geology, Salvador, Brazil. Short Papers 1:313-316.

Alvarenga, C.J.S., Trompette, R. 1992. Glacial influenced turbidite sedimentation in the uppermost Proterozoic and Lower Cambrian of the Paraguay Belt (Mato Grosso, Brazil). Palaeogeography, Palaeoclimatology, Palaeoecology, 92: 85-105.

Alvarenga, C.J.S., Trompette, R. 1993. Evolução tectônica brasiliana da Faixa Paraguai: a estruturação da região de Cuiabá. Revista Brasileira de Geociências, 23: $18-30$.

Alvarenga, C.J.S., Trompette, R. 1994. A Faixa Paraguai e sua compartimentação estratigráfica e tectônica. Anais do 38 Congresso Brasileiro de Geologia, Camboriú, Sociedade Brasileira de Geociências, 1:239-240.

Babinski, M., Trindade, R.I.F., Alvarenga, J.C., Boggini, P.C., Liu, D., Santos, R.V. 2006. Geochronological constrains on the neoproterozóic glaciations in Brazil. Snowball Earth Conference, Ascona, Switzerland.

Babinski, M., Van Schmus, W.R. Chemale Jr., F. 1999. Pb-Pb dating and Pb isotope geochemistry of Neoproterozoic carbonates rocks from the São Francisco Basin, Brazil: implications for the mobility of $\mathrm{Pb}$ isotopes during tectonism and metamorfism. Chemical Geology, 160: 175-199.

Banner, J.L., 2004. Radiogenic isotopes: systematics and applications to Earth surface processes and chemical stratigraphy. Earth-Science Reviews, 65:141-194.

Barfod, G.H., Albarede, F., Knoll, A.H., Xiao, S., Télouk, P., Frei, R., Baker, J. 2002. New $\mathrm{Lu}-\mathrm{Hf}$ and $\mathrm{Pb}-\mathrm{Pb}$ age consraints on the earliest animal fossils. Earth Planetary Science Letters, 201: 203-212.

Barros, A.M., Silva, R.H., Cardoso, O.R.F.A., Freire, F.A., Souza Júnior, J.J.S, Rivetti, M., Luz, D.S., Palmeira, R.C.B., Tassinari, C.C.G. 1982. Folha SD 21 Cuiabá; Geologia. Projeto RADAM BRASIL, Levantamento de Recursos Naturais. Ministério das Minas e Energia, Rio de Janeiro, 26:25-175.

Bingen, B., Griffin, W.L., Torsvik, T.H., Saeed, A. 2005. Timing of late Neoproterozoic glaciation on Baltica constrained by detrital geochronology in the Hedmark Group, southeast Norway. Terra Nova, 17: 593-596. 
Biscaye, P. E., 1965, Mineralogy and sedimentation of Recent deep-sea clay in the Atlantic Ocean and adjacent seas and oceans. Geological Socciety of America Bulletin 89: 803-832.

Boggiani, P.C, Babinski, M., Yamamoto, J.K., Fairchild, T., Riccomini, C, Diragitch, A.A., Liu, D. 2005. U-Pb SHRIMP investigation of ash beds in the Corumbá Group (Ediacaran), Paraguai Belt, Brazil. Symposium on Neoproterozoic-Early Paleozoic Events in SW-Gondwana, IGCP Project 478, Third Meeting, Namibia, p. 13-16.

Boggiani, P.C, Gaucher. C., Sial, A.N., Babinski. M., Simon, C.M., Riccomini, C, Ferreira, V.P., Fairchild, T.R. 2010. Chemostratigraphy of the Tamengo Formation (Corumba Group, Brazil):A contribution to the calibration of the Ediacaran carbonisotope curve Precambrian Res., doi:10.1016/j.precamres.2010.06.003 (in press).

Boggiani, P.C. 1998. Análise estratigráfica da Bacia Corumbá (Neoproterozóico) - Mato Grosso do Sul. Tese de Doutoramento, Instituto de Geociências da Universidade de São Paulo, São Paulo, 181 p.

Boggiani, P.C., Sial, A.N., Babinski, M., Ferreira, V.P. 2003. New carbon isotopic data from the Corumbá Group as a contribuition to a composite section for the Neoprotrozóic III in South America. Symposium on Neoproterozoic-Early Paleozoic Events in SW-Gondwana, IGCP Project 478, First Meeting, South Africa, p. 13-16.

Bouma, A.H. 1962. Sedimentology of some flysch deposits. Elsevier, Amsterdam. 168 pp.

Bowring, S., Myrow, P., Landing, E., Ramezani, J., Grotzinger, J. 2003. Geocronological constraints on terminal Proterozoic events and the rise of metazoans. Geophysical Research Abstracts, 5: 213-219.

Brocks, J.J., Summons, R.E. 2003. Sedimentary hydrocarbons, biomarkers for early life. Treatise on Geochemistry 8: 63-115.

Broecker, W.S., Peng, T.S. 1982. Tracers in the sea. Eldio Press, New York, 690p.

Burns, S.J. and Matter, A., 1993. Carbon isotopic record of the latest Proterozoic from Oman. Eclogae Geologicae Helvetiae, 86: 5952607.

Calver C. R. and Lindsay J. F. 1998. Ediacarian sequence and isotope stratigraphy of the Officer Basin, South Australia. Australian Journal of Earth Sciences 45:513532.

Calver, C.R., 2000. Isotope stratigraphy of the Ediacaran (Neoproterozoic III) of Adelaide Rift Complex, Austrália, and the overprint of water column stratification. Precambrian Research, 100: 121-150.

Canfield, D.E., Poulton, S.W. and Narbonne, G.M., 2007. Late-Neoproterozoic deepocean oxygenation and the rise of animal life. Science, 315: 92-95.

Canfield, D.E., Poulton, S.W., Knoll, A.H., Narbonne, G.M., Ross, G., Goldberg, T. and Strauss, H., 2008. Ferruginous conditions dominated later Neoproterozoic deepwater chemistry. Science, 321: 949-952.

Castelneau, F. 1850. Expedition dans les parties centrales de l'Amérique du Sud. Histoire du Voyage. Libraire Editeur, Paris, Tomo II. 483 p. 
Claypool, G.E., Holser, W.T., Kaplan, I.R., Sakai, H., Zak, I. 1980. The age curves of sulfur and oxygen isotopes in marine sulfate and their mutual oxygen isotopes in marine sulfate and their mutual interpretation. Chemical Geology 28:199-260.

Coates, A. G., E. G. Kauffman. 1973. Stratigraphy, paleontology and paleoenvironment of a Cretaceous coral thicket, Lamy, New Mexico. Journal of Paleontology, 47: 953968.

Condon AG, Richards RA, Rebetzke GJ, Farquhar GD (2002) Improving intrinsic wateruse efficiency and crop yield. Crop Sci. 42:122-131.

Condon, D., Zhu, M., Bowring, S.A., Yang, A., Jin, Y. 2005. U-Pb Ages from the Neoproterozoic Doushantuo Formation. China. Science 308: 95-98.

Condon, D.J., Prave, A.R. 2000. Two from Donegal: Neoproterozoic glacial episodes on the northeast margin of Laurentia. Geology, 28: 951-954.

Cook, H.E., Egbert, R.M. 1981. Carbonate submarine fans along a paleozoic prograding continental margin, western United States. AAPG Bulletim, 65: 913.

Cook, H.E., Egbert, R.M. 1981.Carbonate submarine fans along a paleozoic prograding continental margin, western United States. AAPG Bulletim, 65: 913

Corsetti, F. A., Olcott, A. N. Bakermans, C. 2006. The biotic response to Neoproterozoic snowball Earth. Palaeogeography, Palaeoclimatology, Palaeoecology, 232: 114130.

Corsetti, F.A. and Kaufman, A.J. 2003. Stratigraphic investigations of carbon isotope anomalies and Neoproterozoic ice ages in Death Valley, California. Bulletin of the Geological Society of America, 115: 9162932.

Del'Arco, J.O., Silva, R.H., Tarapanoff, I., Freire, F.A., Pereira, L.G.M., Souza, S.L., Luz, L.G., Palmeira, R.C.B., Tassinari, C.C.G. 1982. Geologia, Folha SE.21 Corumbá e parte da Folha SE.20. Ministério de Minas e Energia, Projeto RADAMBRASIL, Rio de Janeiro, p. 25-160.

Demicco, R. V., and Hardie, L. A., 1994. Sedimentary structures and early diagenetic features of shallow marine carbonate deposits: Society of Economic Paleontologists and Mineralogists Atlas Series 1, 255 p.

Dempster, T.J., Rogers, G., Tanner, P.W.G., Bluck, B.J., Muir, R.J., Redwood, S.D., Ireland, T.R., Paterson, B.A. 2002. Timing of deposition, orogenesis and glaciation within the Dalradian rocks of Scotland: Constraints from $\mathrm{U}-\mathrm{Pb}$ zircon ages. Journal of Geological Society, London, 159: 83-94.

Domack, E. W., 1984. Rhythmically bedded glaciomarine sediments on Whidbey Island, Washington. Jour. of Sedimentary. Petrology, 54, p. 589-602

Elie, M., Nogueira, A.C.R, Trindade, R.I.F, Nédélec, A., Kening, F. 2007. A red algal bloom in the Neoproterozoic Snowball Earth aftermath. Terra Nova, 19:303-308.

Evans, G., Schmidt, V., Bush, P., Nelson, H. 1969. Stratigraphy and geologic history of the sabkha, Abu Dhabi, Persian Gulf. Sedimentology, 12: 145-159. 
Evans, J.W. 1894. The Geology of Mato Grosso, particularly the region drained by the upper Paraguay. Journal of Geological Society, London, L(II): 85-104.

Eyles C.H., Eyles N., Miall A.D. 1985. Models of glacio-marine sedimentation and their application to the interpretation of ancient glacial sequences. Palaeogeo. Palaeoclim. Palaeoeco., 51:15-84.

Eyles N. 1993. Earth glacial record. Earth Science Reviews, 35:1-248

Eyles, C.H. 1987. Glacially influenced submarine-channel sedimentation in the Yakataga Formation, Middleton Island, Alaska: Jounal of Sedimentary Petrology, 57:1004-1017.

Eyles, N., Eyles, C.H., 1989. Glacially-influenced deep-marine sedimentation of the late Precambrian Gaskiers Formation, Newfoundland, Canada. Sedimentology, 36:. 601-620.

Eyles, N., Januszczak, N. 2004. 'Zipper-rift': a tectonic model for Neoproterozoic glaciations during the breakup of Rodinia after $750 \mathrm{Ma}$. Earth-Science Reviews, 65:1-73.

Fairchild, I.J., 1993. Balmy shores and icy wastes: the paradox of carbonates associated with glacial deposits in Neoproterozoic times. Sedimentology Review, 1: 1216.

Fairchild, I.J., 1993. Balmy shores and icy wastes: the paradox of carbonates associated with glacial deposits in Neoproterozoic times. Sedimentology Review, 1: 1216.

Fairchild, T.R. 1978. Evidencias peleontológicas de uma possivel idade edicariana ou Cambriano inferior, para parte do grupo Corumbá, Mato Grosso do Sul. Boletim Especial, $30^{\circ}$ Congresso Brasileiro de Geologia, Sociedade Brasileira de Geologia, Recife. Anais 1: 38-39.

Ferreira, C.O. 2010. A extensão do arco magmático de Goiás ao longo do lineamento transbrasiliano: estudo baseado na aplicação dos métodos U-Pb e Lu-Hf por LAMC-ICP-ME. Dissertação de mestrado, Universidade São Paulo. 91 p.

Figueiredo, A.J.A., Olivatti, O. 1974. Projeto Alto Guaporé, Relatório Final Integrado. Departamento Nacional de Produção Mineral e Companhia de Pesquisa de Recursos Minerais, Goiânia, v. 11.

Figueiredo, M. F., Babinski, M., Alvarenga, C. J. S., Pinho, F.E.C. 2006a. Ocorrência de magmatismo máfico paleocênico, Faixa Paraguai, Mato Grosso. Anais do $43^{\circ}$ Congresso Brasileiro de Geologia, Maceió. Anais, 1 p.

Figueiredo, M. F., Babinski, M., Alvarenga, C. J. S., Pinho, F.E.C., Simon, C. M. 2006 b. Chemostratigraphy (C, O and $\mathrm{Sr}$ ) of Ediacaran post-glacial carbonates of Paraguay

Figueiredo, M.F. 2006. Quimioestratigrafia das rochas ediacarianas do extremo norte da Faixa Paraguai, Mato Grosso. Dissertação de Mestrado, Instituto de Geociências, Universidade de São Paulo. 105 p. 
Figueiredo, M.F., Babinski, M., Alvarenga, C.J.S., Pinho, F.E.C. 2008. Nova unidade litoestratigráfica registra glaciação Edicarana em Mato Grosso: Formação Serra Azul. Geologia-USP, 8: 65-75.

Figueiredo, M.F., Babinski, M., Alvarenga, C.J.S., Pinho, F.E.C., 2005a. Nova unidade litoestratigráfica: Formação Serra Azul, Faixa Paraguai, Mato Grosso. IX Simpósio de Geologia do Centro-Oeste, Brazil. Anais p. 23-25.

Figueiredo, M.F., Babinski, M., Alvarenga, C.J.S., Pinho, F.E.C., 2005b. Quimioestratigrafia de $\mathrm{C}, \mathrm{O}$ e $\mathrm{Sr}$ dos carbonatos ediacaranos da Faixa Paraguai, Mato Grosso. X Congresso Brasileiro de Geoquímica e II Simpósio de Geoquímica dos Países do Mercosul. Anais em mídia digital, 3 p.

Fike D.A., Grotzinger J.P., Pratt L.M., Summons R.E. 2006. Oxidation of the Ediacaran Ocean. Nature, 444: 744-747.

Font, E., Nédélec, A, Trindade, R.I.F., Macouin, M., Charriere, A. 2006. Chemostratigraphy of the Neoproterozoic Mirassol d'Oeste cap dolostones (Mato Grosso, Brazil): An alternative model for Marinoan cap dolostones formation. Earth and Planetary Science Letters, 250: 89-103.

Frakes, L.A. 1978. Diamictite. In: Fairbridge, R.W. \& Bourgeois, J. (eds). The Encyclopedy of Sedimentology. Stroudsburg, Hutchinson and Ross. p. 262-263.

Fürsich, F.T. 1995. Approaches to palaeoenvironmental reconstructions. GEOBIOS 18: 183-195.

Ganzer, E. B., Figueiredo, M. F. 2004. Mapeamento Geológico e Estudo Geoquímico do Gr. Alto Paraguai, Marzagão-MT. Trabalho de Conclusão de Curso, Instituto de Ciências Exatas e da Terra, Universidade Federal de Mato Grosso, 117 p.

Gostin, V.A., Haines, P.W., Jenkins, R.J.F., Compston, W. 1986. Impact ejecta horizon within late Precambrian shales, Adelaide geosyncline, South Australia. Science, 233: 542-544.

Grey, K., Walter, M.R., Calver, C.R. 2003. Neoproterozoic biotic diversification: Snowball Earth or aftermath of the Acraman impact. Geology, 31:459-462.

Grotzinger, J.P., Knoll, A.H.. 1995. Anomalous carbonate precipitates: Is the Precambrian the key to the Permian? Palaios,10: 578-596.

Guo, Q., Strauss, H., Liu, C., Goldberg, T., Zhu, M., Pi, D., Heubeck, C., Vernhet, E., Yang, X., Fu, P., 2007. Carbon isotopic evolution of the terminal Neoproterozoic and early Cambrian: evidence from the Yangtze Platform, South China. Palaeogeogr. Palaeoclimatol. Palaeoecol. 254, 140-157.

Hallam, 1984. A. Hallam, Continental humid and arid zones during the Jurassic and Cretaceous. Palaeogeogr. Palaeoclimatol. Palaeoecol. 47 (1984), pp. 71-108.

Halverson, G., 2006. A Neoproterozoic chronology. In: Xiao, S., Kaufman, A. (Eds.), Neoproterozoic Geobiology and Paleobiology. Topics in Geobiology, Springer, New York. 27:. 231-271. 
Halverson, G.P., Hoffman, P.F., Schrag, D.P., Maloof, A.C., 2005. Toward a Neoproterozoic composite carbon-isotope record. Geological Society of America, 117: 1181-1207.

Hennies, W.T., 1966.Geologia do Centro-Norte Mato-Grossense. Tese de Doutoramento, Escola Politécnica, Universidade de São Paulo, 65 p.

Hidalgo, R.L.L. 2007. Vida após as glaciações globais neoproterozóicas: um estudo microfossifífero de capas carbonáticas dos Crátons do São Francisco e Amazônico. Tese de doutoramento, Instituto de Geociências, Universidade de São Paulo. 195 p.

Hoffman, P.F., Kaufman, A.J., Halverson, G.P., Schrag, D.P. 1998. A Neoproterozoic Snowball Earth. Science, 281:1342-1346.

Holser, W.T. 1977. Catastrophic chemical events in the history of the ocean. Nature 267: 403-408.

Hurtgen, M.T., Halverson, G.P., Arthur, M.A., Hoffman, P.F. 2006. Sulfur cycling in the aftermath of a 635-Ma snowball glaciation: Evidence for a syn-glacial sulfidic deep ocean. Earth and Planetary Science Letters, 245: 551-570.

Hyde, W.T., Crowley, T.J., Baum, S.K., Peltier, R. 2000. Neoproterozoic 'snowball Earth' simulations with a coupled climate/ice-sheet model. Nature 405: 425-429.

Jiang, G., Kaufman, A.J., Christie-Blick, N., Zhang, S., Wu, H. 2007. Carbon isotope variability across the Ediacaran Yangtze platform in South China: implications for a large surface-to-deep ocean $\delta^{13} \mathrm{C}$ gradient. Earth Planetary and Science Letters. 261: 303-320.

Kah, L.C. 2000. Depositional $\delta^{18} \mathrm{O}$ signatures in Proterozoic dolostones: constraints on seawater chemistry and early diagenesis. In: Grotzinger, J.P., James, N.P. (eds.), 2000. Carbonate sedimentation and diagenesis in the involving Precambrian World. Society for Sedimentary Geology, Special Publication 67.

Kaplan, I. R. 1983. Stable isotopes of sulfur, nitrogen and deuterium in Recent marine environments. In: Arthur, M. A., Anderson, T. F., Kaplan, I. R., Veizer, J., Land, L. S. (Eds.). Stable Isotopes in Sedimentary Geology. Columbia, Society for Sedimentary Geology, Short course, p. 2-1-2-108.

Kaufman, A.J. \& Knoll, A.H. 1995. Neoproterozoic variations in the C-isotopic composicional of seawater: Stratigrafic and biogeochemical implications. Precambrian Research, 73:27-49.

Kaufman, A.J., Hayes, J.M., Knoll, A.H., Germs, G.J.B. 1991. Isotopic composition of carbonates and organic carbon from upper Proterozoic successions in Namibia: stratigraphic variation and the effects of diagenesis and metamorphism. Precambrian Research 49: 301-327.

Kaufman, A.J., Knoll, A.H., Narbonne, G.M. 1997. Isotopes, ice ages, and terminal Proterozoic Earth history. National Academy of Sciences Proceedings 94:66006605. 
Kendall, C.G.St.C., Skipwith, P.A. 1969. Geomorphology of a recent shallow water carbonate province: Khor al Bazan, Trucial Coats, southwest Persian Gulf. Geological Society of America Bulletin, 80: 865-891.

Kennedy, M.J., Christie-Blick, N. Sohl, L.E. 2001. Are Proterozoic cap carbonates and isotope excursions a record of gas hydrate destabilization following Earth's coldest intervals. Geology, 29: 443-446.

Kirschvink, J.L. 1992. Late Proterozoic Low-Latitude Global Glaciation: the Snowball Earth. In: Schopf, J.W., Klein, C. (Eds.) 1992: The Proterozoic Biosphere - A Multidisciplinary Study. Cambridge University Press, p 51-52.

Knauth, L. P. 1979: A model for the origin of chert in limestone. Geology, 7: 274-277.

Knoll, A.H. 1991. End of the Proterozoic Eon. Scientific America, 265: 64-73.

Knoll, A.H., Walter, M.R., 1992. Latest Proterozoic stratigraphy and Earth history: Nature, 356: 673-678.

Krausse, F.F., Oldershaw, A.E. 1979. Submarine carbonate breccia beds - a depositional model for two-layer, sediment gravity flows from the Sekwi Formation (Lower Cambrian), Mackenzie Montains, Northwest Territories, Canada. Canadian Journal of Earth Science 16: 189-199.

Krausse, F.F., Oldershaw, A.E. 1979. Submarine carbonate breccia beds - a depositional model for two-layer, sediment gravity flows from the Sekwi Formation (Lower Cambrian), Mackenzie Montains, Northwest Territories, Canada. Canadian Journal of Earth Science 16: 189-199.

Kroopnik, P. 1980. The distribution of ${ }^{13} \mathrm{C}$ in the Atlantic Ocean. Earth and Planetary Science Letters, 30: 469-484.

Laschet, C. 1984. On the origin of cherts. Facies, 10: 257-289.

Le Guerroue, E., Allen, P.A., Cozzi A. 2006. Chemostratigraphic and sedimentological framework of the largest negative carbon isotopic excursion in Earth history: the Neoproterozoic Shuram Formation (Nafun Group, Oman). Precambrian Research, 146: 68-92.

Li, C., Love, G.D., Lyons, T.W., Fike, D.A., Sessions, A.L., Chu, X. 2010. A stratified redox model for the Ediacaran ocean. Science, 328: 80-83.

Luz, J.S., Oliveira, A.M., Lemos, D.B., Argolo, J.L., Souza, N.B., Abreu Filho, W. 1978. Projeto Província Serrana, relatório final. Departamento Nacional de Produção Mineral e Companhia de Pesquisa de Recursos Minerais, Goiânia. 1: 136 p.

Luz, J.S., Oliveira, A.M., Souza, J.O., Motta, J.F.M., Tanno, L.C., Carmo, L.S., Souza, N.B., Abreu Filho, W. 1980. Projeto Coxipó, relatório final. Departamento Nacional de Produção Mineral e Companhia de Pesquisa de Recursos Minerais, Goiânia. 1: $136 \mathrm{p}$.

Maciel, P. 1959. Tilito Cambriano (?) no Estado de Mato Grosso. Boletim da Sociedade Brasileira de Geologia, 8:31-39.

Martin, H., 1965. The Precambrian geology of South West Africa and Namaqualand. Precambrian Research Unit, University of Cape Town, Bulletin,, 4: 177 pp. 
McFadden, K.A., Huang, J., Chu, X., Jiang, G., Kaufman, A.J., Zhou, C., Yuan, X., Xiao, S. 2008. Pulsed oxidation and biological evolution in the Ediacaran Doushantuo Formation. PNAS, 105: 3197-3202.

Melezhik, V.A., Pokrovsky, B.G., Fallick, A.E., Kuznetsov, A.B., Bujakaite, M.I., 2009. Constraints onthe ${ }^{87} \mathrm{Sr} /{ }^{86} \mathrm{Sr}$ of Late Ediacaran seawater: insights from high-Sr limestones. Journal of Geological Society, London, 166:183-191.

Mount, J. 1985. Mixed siliciclastic and carbonate sediments: a proposed first-order textural and compositional classification. Sedimentology, 32: 435-442.

Mullins, H.T., Neumann, A.C. 1979. Deep carbonate bank margin structure and sedimentation in the northern Bahamas. SEPM Special Publication, 27:165-192.

Myrow, P.M., Kaufman, A.J. 1999. A newly discovered cap carbonate above Varangerage glacial deposits in Newfoundland, Canada. Journal of Sedimentary Research, 69: 784-793.

Narbonne, G.M., and Gehling, J.G., 2003, Life after snowball: The oldest complex Ediacaran fossils: Geology, 31: 27-30.

Narbonne, G.M. 2005. The Ediacara biota: Neoproterozoic origin of animals and their ecosystems. Annual Reviews of Earth and Planetary Sciences, 33: 13.1-13.22.

Nogueira, A.C.R. 2003. A plataforma carbonática Araras no sudoeste do Cráton Amazônico, Mato Grosso: Estratigrafia, contexto paleoambiental e correlação com os eventos glaciais do Neoproterozóico. Tese de Doutoramento, Instituto de Geociências da Universidade de São Paulo, 173 p.

Nogueira, A.C.R., Riccomini, C. 2006. Grupo Araras (Neoproterozóico) na parte norte da Faixa Paraguai e Sul do Craton Amazônico, Brasil. Revista Brasileira de Geociências, 36: 576-587.

Nogueira, A.C.R., Riccomini, C. 2006. O Grupo Araras da Faixa Paraguai Norte, Sul do Cráton Amazônico. Revista Brasileira de Geociências, 36: 623-640.

Nogueira, A.C.R., Riccomini, C., Sial, A.N., Moura, C.A.V., Fairchild, T.R. 2003. Softsediment deformation at the base of the Neoproterozoic Puga cap carbonate (sowthwestern Amazon craton, Brazil) confirmation of rapid icehouse to greenhouse transition in Snowball Earth. Geology, 31:613-616.

Nogueira, A.C.R., Riccomini, C., Sial, A.N., Moura, C.A.V., Trindade, R.I.F., Fairchild, T.R., 2007. Carbon and strontium isotope fluctuations and paleoceanographic changes in the late Neoproterozoic Araras carbonate platform, southern Amazon craton, Brazil. Chemical Geology, 237: 168-190.

Oldershaw, A.E. 1979. Submarine carbonate breccia beds - a depositional model for two-layer, sediment gravity flows from the Sekwi Formation (Lower Cambrian), Mackenzie Montains, Northwest Territories, Canada. Canadian Journal of Earth Science 16: 189-199.

Paes Leme, A.B. 1912. Mineralogia e geologia. Comissão de linhas telegráficas e estratégicas de Mato Grosso ao Amazonas, anexo 5.23 p.

Pazos, P.J., Bettucci, L.S., Loureiro, J. 2008. The Neoproterozoi glacial Record in the Río de la Plata Craton: a critical reappraisal. Geological Society, London, Special Publications 294: 343-364 
Pinho, F. E. C., 1990. Estudo das rochas encaixantes e veios mineralizados a ouro do Grupo Cuiabá, na região denominada Garimpo do Araés, Nova Xavantina, MT. Dissertação de Mestrado, Instituto de Geociências, UFGRS, 114p.

Pinho, F.E.C., Sial, A.N., Figueiredo, M.F. 2003. Contribution to the Neoproterozoic Cand O-isotopic record: carbonate rocks from the Paraguay Belt, Mato Grosso, Brazil. IV South American Symposium on Isotope Geology, Salvador, Brazil. Short Papers 1:390-393.

Ribeiro Filho, W., Luz, J.S., Abreu Filho, W. 1975. Projeto Serra Azul, relatório final. Departamento Nacional de Produção Mineral e Companhia de Pesquisa de Recursos Minerais, Goiânia. 1: 104 p.

Roberts, J.D. 1976. Late Precambrian Dolomites, Vendian Glaciation, and Synchroneity of Vendian Glaciations. Journal of Geology, 84: 47-63.

Rothman, D.H., Hayes, J.M., Summons, R.E. 2003.Dynamics of the Neoproterozoic carbon cycle. Procedures of National Academy of Sciences, 100: 124-129.

Ruiz, A. S., Santos, A. A. 1999. O domínio interno da Faixa Paraguai na região de Nova Xavantina - MT. Dados preliminares. VII Simpósio de Geologia do Centro-oeste, Brasília. Boletim de resumos, p. 10.

Ruffell, A., McKinley, J.M., Worden, R.H. 2002. Comparison of clay mineral stratigraphy to other proxy palaeoclimate indicators in the Mesozoic of NW Europe. Philosophical Transactions of the Royal Society A, London, 360: 675-693.

Santos, J.X., Coelho, R.S. 2004. Mapeamento geologico na região de Marzagão e Bom Jardim, Municipio de Nobres-MT. 2003. Trabalho de Conclusão de Curso, Instituto de Ciências Exatas e da Terra, Universidade Federal de Mato Grosso.

Schidlowski M., Eichmann R., Junge C.E. 1976. Carbon isotope geochemistry of the Precambrian Lomagundi carbonate province, Rhodesia. Geochimica et Cosmochimica Acta 40: 449-455.

Schidlowski, M., Appel, P.W.U., Eichmann, R., Junge, C.E. 1979, Carbon isotope geochemistry of the $3.7 \times 10 \mathrm{yr}$ old Isua sediments, West Greenland: Implications for the Archaean carbon and oxygen cycles. Geochimica et Cosmochimica Acta 43:189-199.

Schmidt, P.W., Williams, G.E., 1995. The Neoproterozoic climatic paradox: equatorial palaeolatitude for Marinoan glaciation near sea level in South Australia. Earth planetary Science Letters, 134: 107-124.

Schneider, J. F. 1975. Recent tidal deposits, Abu Dhabi, UAE, Arabian Gulf. In: Ginsburg, R. N. (ed.), Tidal Deposits. Springer Verlag, Berlin, 209-214.

Schobbenhaus, C., Gonçalves, J.H., Santos, J.O.S., Abram, M.B., Leão Neto, R., Matos, G.M.M., Vidotti, R.M. (eds.). 2003. Carta Geológica do Brasil ao Milionésimo, Programa Levantamentos Geológicos Básicos do Brasil, CPRM, Brasília. 35 CD-ROMs. 
Scott, C., T. W. Lyons, A. Bekker, Y. Shen, S. W. Poulton, X. Chu, And A.D. Anbar. 2008. Tracing the stepwise oxygenation of the Proterozoic ocean. Nature, 452:456459

Shen, Y., Zhang, T.G., Chu, X.L. 2005. C-isotopic stratification in a Neoproterozoic postglacial ocean. Precambrian Res. 137, 243-251.

Shen, B., Xiao, S., Kaufman, A.J., Bao, H. 2008. Stratification and mixing of a postglacial Neoproterozoic ocean: Evidence from carbon and sulfur isotopes in a cap dolostone from northwest China. Earth and Planetary Science Letters, 265: 209228.

Shin, 1982 P.K.S. Shin, Littoral and benthic investigations of the west coast of Ireland - XV. The macrobenthic communities of North Bay (Galway Bay), Proceedings of the Royal Irish Acadademy, 82B: 179-191.

Silva C.H. 1999. Caracterização Estrutural de Mineralizações auríferas do Grupo Cuiabá, Baixada Cuiabana (MT). Dissertação de Mestrado, Universidade Estadual Paulista, Rio Claro, 134p.

Simon, C.M. 2007. Quimioestratigrafia isotópica (C, O, Sr) dos carbonatos da Formação Tamengo, Grupo Corumbá, MS. Trabalho Final de graduação, Instituto de Geociências, Universidade de São Paulo. 43 p.

Stanley, G.D., Jr. 1979. Paleoecology, structure, and distribution of Triassic coral buildups in western North America: University of Kansas Paleontological Contributions, Article 65, 58 p.

Strauss, H., Des Marais, D.J., Hayes, J.M., Summons, R.E. 1992. The carbon-isotopic record. In The Proterozoic Biosphere. Schopf, J.W., and Klein, C. (eds). New York: Cambridge University Press, pp. 117-127.

Strauss, H. 2004. $4 \mathrm{Ga}$ of seawater evolution: evidence from the sulphur isotopic composition of sulphate. In: Amend, JP., Edwards, K.J., Lyons, T.W. (Eds.). Sulphur Biogeochemistry - Past and Present. Geologycal Society of America 379:195-205.

Strauss, H., Banerjee, D.M., Kumar, V. 2001. The sulphur isotopic composition of Neoproterozoic to early Cambrian seawater - evidence from cyclic Hanseran evaporites, NW India. Chemical Geology, 175: 17-28.

Thompson, M.D., Bowring, S.A. 2000. Age of the Squantum 'tillite', Boston basin, Massachusetts: $\mathrm{U}-\mathrm{Pb}$ zircon constraints on terminal Neoproterozoic glaciation, American Journal of Science, 300: 630-655.

Trindade, R.I.F., Font, E., D'Agrella-Filho, M.S., Nogueira, A.C.R., Riccomini, C. 2003. Low-latitude and multiple geomagnetic reversals in the Neoproterozoic Puga cap carbonate of Amazonia. Terra Nova, 15: 441-446.

Trindade, R.I.F., Macouin, M. 2007. Palaeolatitude of glacial deposits and palaeogeography of Neoproterozoic ice ages. External geophysics, Climate and Environment (Glaciology), 339:200-211. 
Trindade, R.I.F., D'Agrella-Filho, M.S., Babinsky, M., Font, E., Brito Neves, B.B. 2004. Paleomagnetism and geochronology of the Bebedouro cap carbonate: evidence for continental-scale Cambrian remagnetization in the São Francisco craton, Brazil. Precambrian Research, 128: 83-103.

Trompette, R. 1994. Pan-African-Brasiliano aggregation of South America and Africa. In: Geology of Gondwana (2000-500 Ma), Rotterdam, Balkema, 350 p.

Varnes, D.J. 1978. Slope Movement Types and Processes. In: Landslides: Analysis and Control. Schuster, R.L., Krizek, R.J. (eds.), National Academy of Sciences, Transportation Research Board. Washington DC. Special Report 176: 11-33.

Vieira, A.J. 1965. Estratigrafia e estrutura da região de Rondonópolis, MT. PETROBRÁS, Relatório Interno, Ponta Grossa. 8 p.

Walde, D. H. G. ; Leonardos, O. H. ; Hahn, G. ; Hahn, R. ; Pflug, H. D. 1982. The first Precambrian megafossil from South America; corumbella werneri. Anais da Academia Brasileira de Ciências, 54: 461-461.

Whittle, G.L., Alsharhan, A.S. 1994. Dolomitization and chertification of the Early Eocene Rus Formation in Abu Dhabi, United Arab Emirates. Sedimentary Geology, 92: 273-285.

Williams, G.E. 1975. Late Precambrian glacial climate and the Earth's obliquity, Geological Magazine,112: 441-465.

Williams, G.E., Wallace, M.W., 2003. The Acraman asteroid impact, South Australia: magnitude and implications for late Vendian environment. Journal of Geological Society, London, 160: 545-554.

Wright,V.P. 1992. A revised classification of limestones. Sedimetological Geology, 76: 177-186.

Xiao, S., Bao, H., Wang, H., Kaufman, A.J., Zhou, C., Li, G., Yuan, X., Ling, H. 2004. The Neoproterozoic Quruqtagh Group in eastern Chinese Tianshan: evidence for a post-Marinoan glaciation. Precambrian Research, 130: 1-26.

Zaine, M.F. 1991. Análise dos fósseis de parte da Faixa Paraguai (MS, MT) e seu contexto temporal e paleoambiental. Tese de Doutoramento, Instituto de Geociências, Universidade de São Paulo. 214 p.

Zhu, M., Zhang, J., Yang, A., 2007. Integrated Ediacaran (Sinian) chronostratigraphy of South China. Palaeogeography, Palaeoclimatology, Palaeoecology, 254: 7-61. 